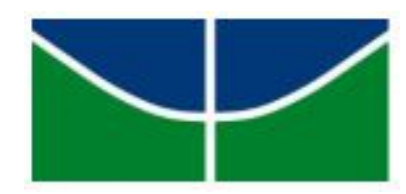

UNIVERSIDADE DE BRASÍLIA

FACULDADE DE EDUCAÇÃO - FE

PROGRAMA DE PÓS-GRADUAÇÃO EM EDUCAÇÃO - PPGE

\begin{abstract}
FORMAÇÃO DE PROFESSORES/COORDENADORES PEDAGÓGICOS A PARTIR DO PROGRAMA NACIONAL ESCOLA DE GESTORES: A experiência no Tocantins
\end{abstract}

Raquel Aparecida Souza 
Tese apresentada à Faculdade de Educação da Universidade de Brasília, como requisito parcial à obtenção do título de Doutorado em Educação.

Orientadora: Professora Dr. ${ }^{\text {a }}$ Raquel de Almeida Moraes. 
Ficha catalográfica elaborada automaticamente, com os dados fornecidos pelo(a) autor(a)

Souza, Raquel Aparecida

SSO729 FORMAÇÃO DE PROFESSORES/COORDENADORES PEDAGÓGICOS f A PARTIR DO PROGRAMA NACIONAL ESCOLA DE GESTORES: A experiência no Tocantins. / Raquel Aparecida Souza; orientador Raquel de Almeida Moraes. -- Brasília, 2016. $270 \mathrm{p}$.

Tese (Doutorado - Doutorado em Educação) -Universidade de Brasilia, 2016.

1. Formação de Professores/Coordenadores Pedagógicos. 2. Programa Nacional Escola de Gestores da Educação Básica. 3. Política e Gestão Educacional. I. Moraes, Raquel de Almeida, orient. II. Título. 
RAQUEL APARECIDA SOUZA

\title{
FORMAÇÃO DE PROFESSORES/COORDENADORES PEDAGÓGICOS A PARTIR DO PROGRAMA NACIONAL ESCOLA DE GESTORES: A experiência no Tocantins
}

\author{
BANCA EXAMINADORA \\ Prof. ${ }^{\text {a }}$ Dr. ${ }^{\text {a }}$ Raquel de Almeida Moraes \\ UnB/FE- Orientadora \\ Prof. Dr. Marcelo Soares Pereira da Silva \\ UFU/Faculdade de Educação \\ Prof. Dr. José Vieira de Souza \\ UnB/Faculdade de Educação \\ Prof. Dr. Carlos Alberto Lopes de Souza \\ UnB/Faculdade de Educação \\ Prof. Dr. Gilberto Lacerda Santos \\ UnB/Faculdade de Educação \\ Prof. Dr. Edson Marcelo Húngaro \\ UnB/Faculdade de Educação Física
}

BRASÍLIA/DF

Dezembro/2016 
A aqueles que me incentivaram, ajudaram, compreenderam minha ausência em momentos tão importantes: meus pais Sônia e Dionizio, ao meu esposo Sergio, aos meus filhos Nicolas e Davi, aos meus irmãos Rejane e Marcelo, meus sogros Maria e José.

A aqueles que, em meio às circunstâncias do século XXI, ainda acreditam que a educação pode tornar o indivíduo mais humano no seu sentido pleno, pode libertar das amarras do mundo material e capitalista que deseja conformar por meio de um ideal hegemônico que os indivíduos devem ser individualistas, consumistas e menos seres humanos. 


\section{AGRADECIMENTOS}

A Deus por me proporcionar saúde física, mental e espiritual e as condições necessárias para que eu desenvolvesse esse trabalho de doutorado que tem um significado muito especial para mim e minha família.

À Raquel Almeida de Moraes, minha orientadora, amiga e excelente professora, pessoa muita humana e compreensível. Sempre me orientou com muita dedicação e sabedoria. Auxiliou-me desde o início do trabalho, em todas suas etapas até chegarmos aqui e ainda auxiliou-me para além do trabalho científico, para que eu pudesse enxergar novas ideias e ver que sempre podemos ir além do que imaginamos ser possível.

Aos professores Katia Augusta Curado e José Vieira, pelas excelentes contribuições no exame de qualificação do projeto de doutorado no ano de 2014.

Aos professores avaliadores que fazem parte dessa banca de defesa, cujas contribuições ajudaram a refinar mais o trabalho: Marcelo Soares, José Vieira, Carlos Alberto e Gilberto Lacerda.

A meus professores da graduação e da pós-graduação que sempre serão referências em minha vida profissional e acadêmica: Raquel Moraes (UnB), José Vieira (UnB), Gilberto Lacerda (UnB), Marcelo Soares (UFU), Maria Vieira (UFU), Olenir Mendes (UFU), Sandra Vidal (UFFS).

Aos meus pais, Sônia e Dionizio, que não mediram esforços para me auxiliar na minha caminhada da formação pessoal e acadêmica, sempre me incentivaram e acreditaram em mim, fazendo o que estava ao seu alcance para me ajudar a chegar aqui.

Ao meu esposo Sergio Silva, meu amor eterno, pela cumplicidade, apoio, incentivo e pela paciência e ajuda nos momentos tensos, de cansaço, de desânimo e de incertezas durante o desenvolvimento desta tese. Foi apoio incondicional para que eu continuasse a caminhada.

Aos meus filhos, presentes de Deus. Ao Nicolas por ser amável e compreensível pelas minhas ausências e impaciências... Ao Davi, que foi gerado e nasceu em meio às minhas angústias durante o desenvolvimento desta tese. A esses dois tesouros, porque entendi que por eles e por sua geração, o esforço vale a pena se queremos e podemos contribuir para uma educação humanizadora. 
Aos meus familiares que, de forma geral, entenderam minha ausência em tantos momentos e me auxiliaram para a realização deste trabalho, cada uma à sua maneira: meus irmãos Rejane e esposo Junior Carrijo; Marcelo e esposa Mariana Souza; meus sogros Maria e José; meus cunhados Fábio, Junior e suas esposas. Aos sobrinhos que amo e anseio que tenham oportunidades de uma excelente formação acadêmica: Mariana, Gabriela, Pedro Henrique, Luiz Felipe e Paulo Gabriel. E aos tios, tias, primos e primas quem tanto amo.

Às amigas e colegas pelo apoio incondicional: Rosiley, Marcia, Rosimeri, Leonice, Andrea, Vanilma, Irene, Mirella, Daniela, Dagma e Juliene.

Aos participantes da pesquisa que prontamente aceitaram o convite e responderam aos questionários: os profissionais/coordenadores e egressos, professores e gestor do curso lato sensu em Coordenação Pedagógica.

À Universidade de Brasília, por meio do Programa de Pós-Graduação em Educação, pela oportunidade proporcionada para minha formação no doutorado em educação.

Aos colegas e professores da Universidade Federal do Tocantins, campus de Miracema e do Instituto Federal de Ciências e Tecnologia de Goiás, campus de Itumbiara-GO, pela compreensão e apoio. 
Conceber a qualificação profissional além do domínio da técnica consiste em estabelecer dimensões da educação que devem estar ao alcance de toda a coletividade. A discussão política, o acesso à cultura, às artes etc, são pressupostos para a construção de uma sociedade na qual a Felicidade seja imperativa. Felicidade não compreendida pelos princípios estreitos do consumismo voltado a poucos e nas fronteiras do reino da necessidade. Felicidade na qual o seu reinado tenha o seu próprio nome. Uma sociedade que decrete a 'utilidade' como fundamental à existência humana. 
SOUZA, Raquel Aparecida. FORMAÇÃO DE PROFESSORES/COORDENADORES PEDAGÓGICOS A PARTIR DO PROGRAMA NACIONAL ESCOLA DE GESTORES: A experiência no Tocantins. 2016, 270f. Tese de Doutorado (Programa de Pós-Graduação em Educação) - Faculdade de Educação, Universidade De Brasília, 2016.

\section{RESUMO}

Esta tese teve como objetivo compreender as determinações da política de formação para os professores/coordenadores pedagógicos, a partir das vozes dos participantes na experiência do curso de especialização lato sensu para Coordenadores Pedagógicos no âmbito do Programa Nacional Escola de Gestores da Educação Básica (PNEGEB), que foi desenvolvido pela UFT e seus parceiros no ano de 2010-2011. Situamos o objeto de estudo no contexto das políticas de formação para professores/gestores na atual sociedade capitalista de forma que, por meio de suas múltiplas determinações, pudéssemos compreender as possibilidades, os limites e os desafios dessa formação, bem como perceber as contradições. Buscando imprimir um olhar crítico-dialético, utilizamos como estratégias metodológicas a pesquisa bibliográfica, documental e a aplicação de questionários. Considerando as dificuldades de identificar os interesses de determinada política, utilizamos uma técnica de distinção entre as Políticas Oficialmente Declaradas - POD e as Políticas de Fato - POF. As primeiras são aquelas descritas, anunciadas, refletidas nos textos e documentos por meio de consensos e as segundas, são aquelas materializadas pelas primeiras e que muitas vezes as contradizem. Dentre os resultados, percebemos que as determinações dessas políticas, no plano macro, visam à formação orientada pelos interesses do capital que busca eficácia e tem o foco nos resultados, como expressam os Organismos Internacionais, sobretudo o Banco Mundial. Contudo, na experiência analisada, essa influência foi em sentido contrário, pois os resultados demarcam possibilidades de uma formação que buscou a gestão democrática e foi considerada satisfatória pela maioria dos participantes. Se por um lado, não é possível afirmar que essas contradições viabilizam a perspectiva da contra-hegemonia ou da crise hegemônica, como postulado por Gramsci, em que os indivíduos se mostram profundamente politizados, conseguem construir uma consciência de classe, criam consensos hegemônicos de superação aos anseios da classe dominante, ou que conseguem transformar-se e transformar o meio em que atuam. Por outro lado, podemos inferir que a formação continuada dos profissionais de coordenação pedagógica no Tocantins forneceu-lhes elementos teóricos e práticos que, nas vozes dos participantes dessa formação, estão auxiliando e contribuindo com o fortalecimento das práticas de gestão democrática na escola, assim como também expressaram mudanças nas suas práticas diárias de trabalho.

Palavras-chave: Formação de Professores/Coordenadores Pedagógicos. Programa Nacional Escola de Gestores da Educação Básica. Política e Gestão Educacional. 


\begin{abstract}
SOUZA, Raquel Aparecida. TEACHER TRAINING/PEDAGOGICAL COORDINATORS FROM THE NATIONAL SCHOOL PROGRAM DEGESTORS: The experience in Tocantins. 2016, 270f. PhD thesis (A post-graduation program in Education) - College education, Brasília University, 2016

This thesis has the objective of understanding the determinations of the training policy for the teachers / pedagogical coordinators, based on the voices of the participants in the experience of the latu sensu specialization course for Pedagogical Coordinators within the National School of Basic Education Managers Program (PNEGEB), which was developed by UFT and its partners in the years 2010-2011. We place the object of study in the context of the policies of education for teachers / managers in the present capitalist society so that, through its multiple determinations, we could understand the possibilities, the limits and the challenges of this formation, as well as perceive the contradictions. Searching for a critical-dialectical look, we used as methodological strategies; a bibliographic and documentary research and the application of questionnaires. Considering the difficulties of identifying the interests of determined politics, we used a technique of distinguishing between Officially Declared Policies - POD and Fact Policies - POF. The former are those described, announced, reflected in the texts and documents by means of consensuses and the latter are those materialized by the first and that often contradict themselves. Among the outcomes, we see that the determinations of these policies, at a macro level form, point to a formation oriented by the interests of the capital that seeks efficacy and is focused on the results, as expressed by the International Organizations, especially the World Bank. However, in the experience analyzed, this influence was felt to be contrary, since the results demarcate possibilities of a formation that sought democratic management and was considered satisfactory by the majority of the participants. If, on the one hand, it is not possible to state that these contradictions make possible the perspective of counter-hegemony or the hegemonic crisis as postulated by Gramsci, in which individuals are deeply politicized, able to construct a class consciousness, create hegemonic consensuses to overcome the dominant class, or who manage to transform themselves and transform the environment where they work. On the other hand, we can infer that the continuing formation of pedagogical professionals on coordination in Tocantins provided them with theoretical and practical elements that, in the voices of the participants of this formation, are helping to contribute to the strengthening of democratic management practices at school, as well as expressing changes in their daily work practices.
\end{abstract}

Keywords: Teacher Training / Pedagogical Coordinators. National School of Basic Education Managers program. Policy and Management education. 


\section{LISTA DE FIGURAS}

Figura 1 - Demanda de formação de coordenadores Seduc-TO....................................... 155

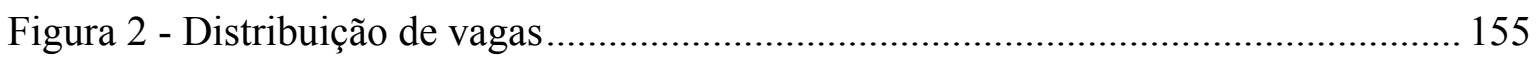

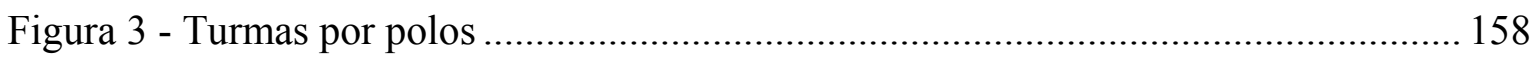

Figura 4 - Distribuição das componentes curriculares por carga horária. ......................... 160

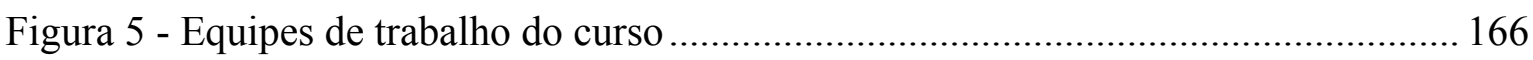




\section{LISTA DE GRÁFICOS}

Gráfico 1 - Produções sobre o PNEGEB por região .......................................................... 170

Gráfico 2 - Áreas do conhecimento das produções sobre o PNEGEB .................................... 172

Gráfico 3 - Função do egresso - exercida na época do curso e após o curso. ......................... 198

Gráfico 4 - Tempo de experiência na docência e na CP...................................................... 199

Gráfico 5 - Distâncias entre as cidades polo do curso e as residências dos cursistas.............207

Gráfico 6 - Ampliação das capacidades de análise e resolução de problemas. ......................210 


\section{LISTA DE TABELAS}

Tabela 1 - Produções sobre o PNEGEB por ano.................................................................... 171

Tabela 2 - Auxílio para a formação inicial e continuada...................................................... 196

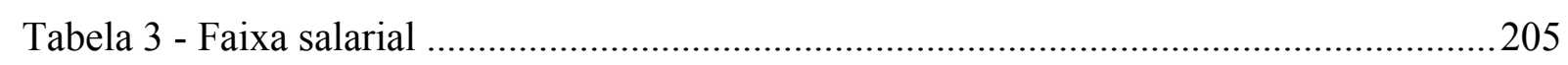

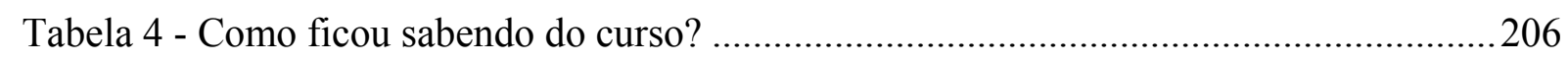

Tabela 5 - Objetivos e perfil esperado............................................................................. 211

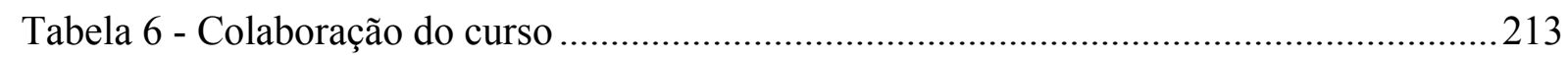

Tabela 7 - Visões sobre mudanças na formação e na prática profissional .............................213

Tabela 8 - Ambiente Virtual de Aprendizagem...................................................................219

Tabela 9 - Atuação e acompanhamento dos professores...................................................... 223

Tabela 10 - Parcerias UFT, MEC para desenvolvimento do curso de especialização. ...........225

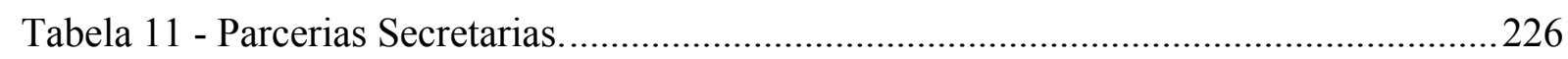




\section{LISTA DE ABREVIATURAS E SIGLAS}

ANFOPE

ANPAE

ANPED

AVA

BM

CEDES

CEPAL

CGDC

Capes

CLT

$\mathrm{CNPq}$

CSN

CTE

$\mathrm{CP}$

DCNP

DFIGE

DN-PNEGEB

DTE

FHC

FMI

FNDE

FORUMDIR

Associação Nacional pela Formação dos Profissionais da Educação

Associação Nacional de Política e Administração em Educação

Associação Nacional de Pesquisa e Pós-Graduação

Ambiente Virtual de Aprendizagem

Banco Mundial

Centro de Estudos Educação e Sociedade

Comissão Econômica para a América Latina

Câmara de Políticas de Gestão, Desempenho e Competitividade

Coordenação de Aperfeiçoamento de Pessoal de Nível Superior

Consolidação das Leis do Trabalho

Conselho Nacional de Desenvolvimento Científico e Tecnológico

Companhia Siderúrgica Nacional

Centro Tecnológico de Educação

Coordenador Pedagógico

Diretrizes Curriculares Nacionais do Curso de Pedagogia

Fortalecimento Institucional e Gestão Educacional

Diretrizes Nacionais do PNEGEB

Diretoria de Tecnologias Educacionais

Fernando Henrique Cardoso

Fundo Monetário Internacional

Fundo Nacional de Desenvolvimento da Educação

Fórum Nacional de Diretores de Faculdades, Centros de Educação ou

Equivalentes das Universidades Públicas Brasileiras

FUNDESCOLA Fundo de Fortalecimento da Escola

\section{GED}

IDEB

IPES

MEC

MR

OCDE

OEA

OIs

OIT

OMC

ONU

Orealc

OTAN

Parfor

PDE

PDE-Escola

PDRAE

PIBIC

PISA

PM

PNEGEB

POD

POF

PPC

Proformação
Gratificação de Estímulo à Docência

Índice de Desenvolvimento da Educação Básica

Instituições Públicas de Ensino Superior

Ministério da Educação

Memorial Reflexivo

Organização para Cooperação e Desenvolvimento Econômico

Organização dos Estados Americanos

Organismos Internacionais

Organização Internacional do Trabalho

Organização Mundial do Comércio

Organização das Nações Unidas

Oficina Regional de Educação para América Latina e Caribe

Organização do Tratado do Atlântico Norte

Plano Nacional de Formação de Professores da Educação Básica

Plano de Desenvolvimento da Educação

Plano de Desenvolvimento da Escola

Plano Diretor da Reforma do Aparelho do Estado

Projeto Institucional de Bolsas de Iniciação Científica

Programa Internacional de Avaliação de Estudantes

Portaria Ministerial

Programa Nacional Escola de Gestores da Educação Básica

Política Oficialmente Declarada

Política de Fato

Projeto Pedagógico do Curso

Programa de Formação de Professores em Exercício 
PROGESTÃO Programa de Capacitação a Distância para Gestores Escolares

ProInfantil Programa de Formação Inicial para Professores em Exercício na Educação Infantil

ProInfo Programa Nacional de Informática na Educação

ProInfoIntegrado Programa Nacional de Formação Continuada em Tecnologia

Educacional

ProUni Programa Universidade para Todos

PT

PTA

Trabalhadores no Brasil

Reuni

Programa de Apoio a Planos de Reestruturação e Expansão das

Universidades Federais

SEB Secretaria de Educação Básica

Seduc-TO Secretaria Estadual de Educação do Tocantins

SEED Secretaria de Educação a Distância

SEMED Secretaria Municipal de Educação

Serce Segundo Estudo Regional Comparativo e Explicativo

Sinaes Sistema Nacional de Avaliação da Educação Superior

TCC Trabalho de Conclusão do Curso

TIC

TPE

TsF

Tecnologias da Informação e Comunicação

Todos Pela Educação

UAB

Teses sobre Feurbach

UEG

Programa Universidade Aberta

UFAcre

Universidade Estadual de Goiás

UFES

Universidade Federal do Acre

UFPE

Universidade Federal do Espírito Santo

UFRN

UFS

UFT

Universidade Federal de Pernambuco

Universidade Federal do Rio Grande do Norte

Universidade Federal de Sergipe

Universidade Federal do Tocantins

UFU

Universidade Federal de Uberlândia

UnB

Universidade de Brasília

Undime - TO União Nacional dos Dirigentes Municipais de Educação

UNESCO Organização das Nações Unidas para a Educação, a Ciência e a Cultura

UNICEF Fundo das Nações Unidas para a Infância

USP

Universidade de São Paulo 


\section{SUMÁRIO}

INTRODUÇÃO

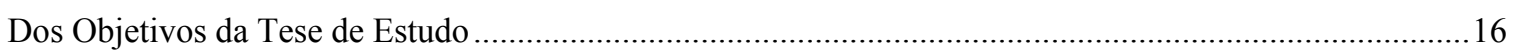

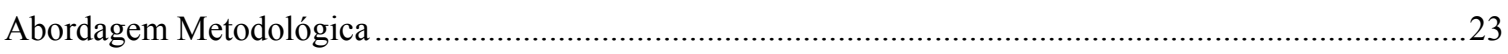

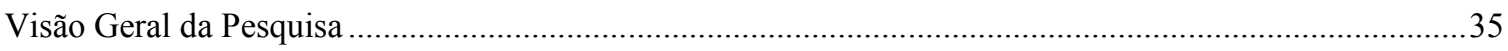

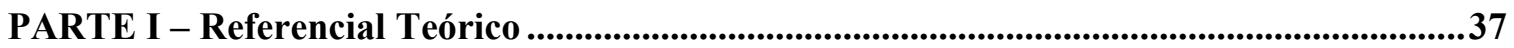

\section{CAPÍTULO I - CONCEPÇÕES E DESENVOLVIMENTO DO ESTADO}

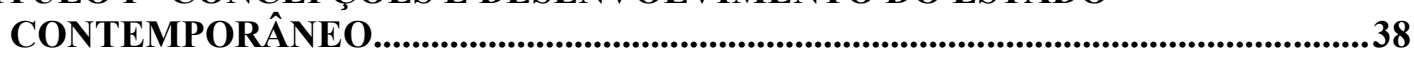

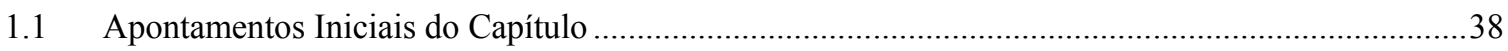

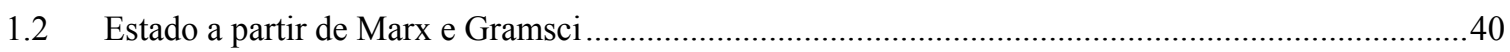

1.3 Noções sobre Estado de Bem-Estar Social e de Estado Neoliberal....................................................53

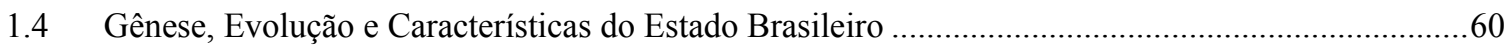

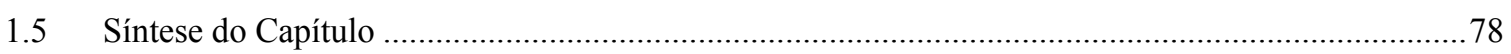

\section{CAPÍTULO II - AGÊNCIAS INTERNACIONAIS E OS CONSENSOS PARAAS}

REFORMAS NA EDUCAÇÃO .......................................................................................81

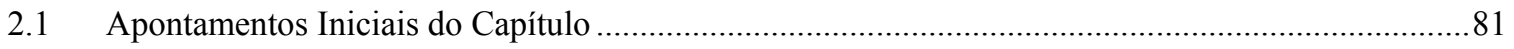

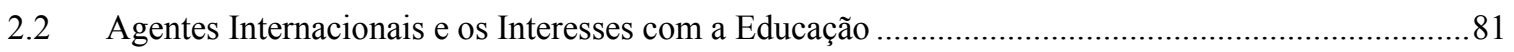

2.3 Banco Mundial e UNESCO: Percursos Históricos de Consensos e Intervenções na Educação..........86

2.4 Reforma na Educação Brasileira a partir de Consensos Estabelecidos pelos OIs ..............................107

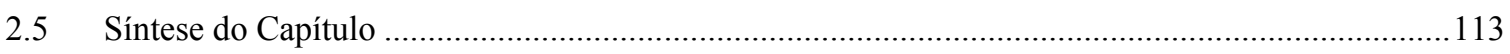

\section{CAPÍTULO III - EDUCAÇÃO A DISTÂNCIA E OS ORGANISMOS INTERNACIONAIS}

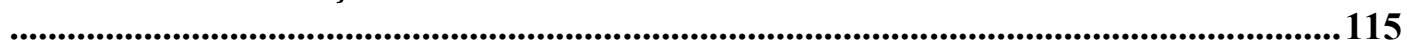

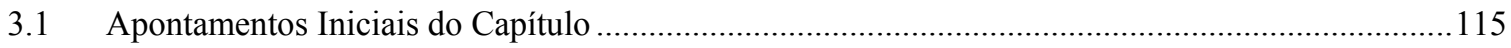

3.2 Educação e Educação a Distância: Pressupostos Teórico-Conceituais ...............................................115

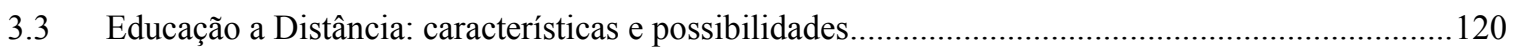

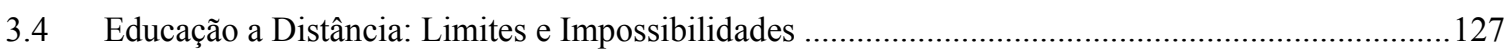

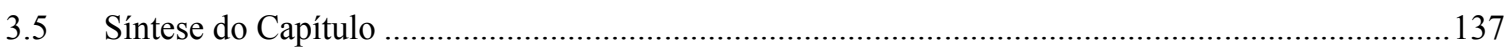

PARTE II - A Pesquisa Empírica _..................................................................................................138

\section{CAPÍTULO IV- O PROGRAMA NACIONAL ESCOLA DE GESTORES DA EDUCAÇÃO} BÁSICA - AÇÃO DAS POLÍTICAS DE FORMAÇAO DE GESTORES...................139

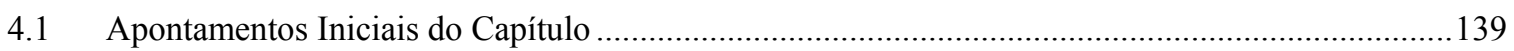

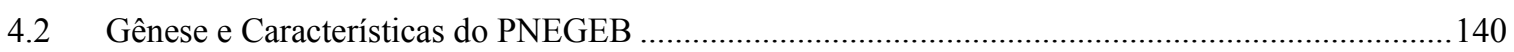

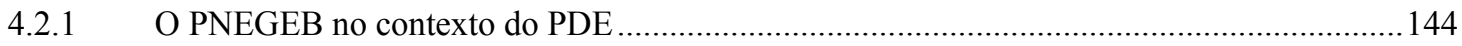

4.2.2 Diretrizes e objetivos do PNEGEB após a revisão do programa ...........................................146

4.3 O PNEGEB no Tocantins a partir da Especialização para Coordenadores Pedagógicos .....................152

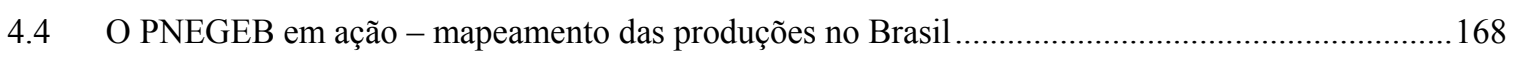

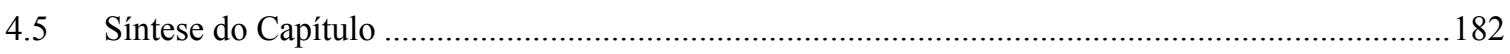




\section{CAPÍTULO V - VISÕES DOS PARTICIPANTES DO CURSO DE ESPECIALIZAÇÃO}

EM COORDENAÇÃO PEDAGÓGICA ..........................................................184

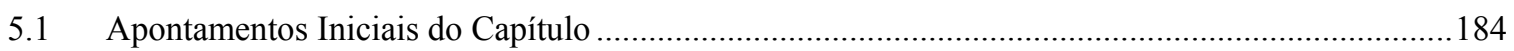

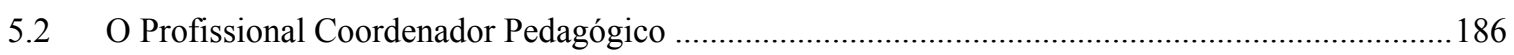

5.3 Os Participantes da Pós-graduação em Coordenação Pedagógica ...................................................194

5.3.1 O Interesse, Dedicação e Ingresso na Pós-graduação .............................................................203

5.4 Perfil Esperado do Egresso a partir dos Objetivos do Curso de Pós-graduação..................................208

5.4.1 Mudanças nas práticas de trabalho.........................................................................................212

5.5 Formação Continuada: em Foco a Metodologia de Aprender a Distância .........................................218

5.5.1 Atuação e Acompanhamento dos Professores ....................................................................222

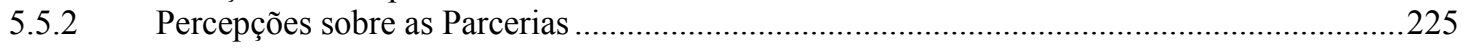

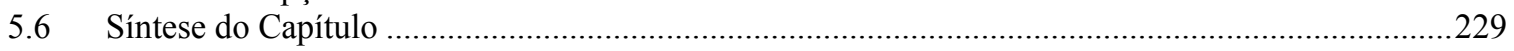

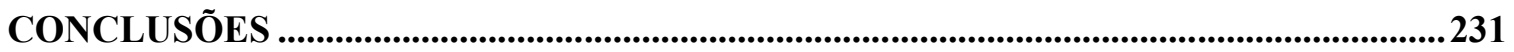

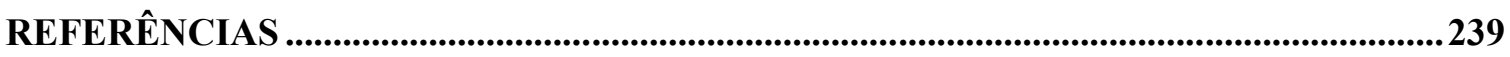

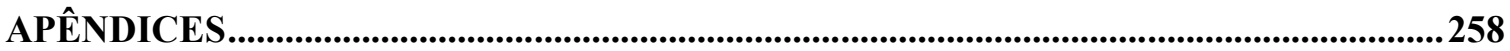

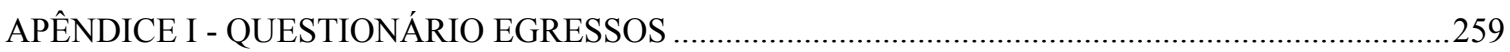

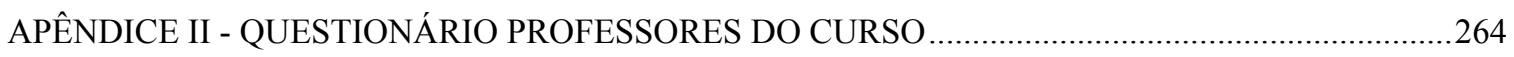

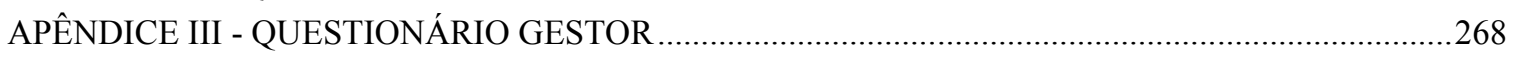

APÊNDICE IV - TERMO DE CONSENTIMENTO LIVRE E ESCLARECIDO …....................................22 


\section{INTRODUÇÃO}

Esta tese apresenta como objeto de estudo o curso de especialização lato sensu em Coordenação Pedagógica do Programa Nacional Escola de Gestores da Educação Básica (PNEGEB) situado no contexto das políticas de formação de professores/gestores ${ }^{1}$ da educação básica, como umas das ações integrantes do conjunto de políticas de formação dos profissionais da educação no Brasil.

\section{Dos Objetivos da Tese de Estudo}

A pesquisa teve como objetivo geral compreender as determinações da política de formação para professores/gestores escolares expressas a partir das vozes dos participantes na experiência do curso de especialização lato sensu em Coordenação Pedagógica, ofertado pela UFT e seus parceiros, no ano de 2010-2011, no âmbito do PNEGEB.

Como objetivos específicos, a pesquisa buscou: identificar questões essenciais sobre a formação, constituição e reestruturação do Estado Moderno a fim de compreendê-lo como agente promotor de políticas públicas educacionais; examinar diretrizes e orientações dos Organismos Internacionais (OIs) para entender sua influência nas reformas educacionais e na formulação e execução de políticas de formação dos profissionais da educação; revisar criticamente noções e conceitos gerais da educação à distância, visando obter elementos para a discussão sobre a formação proposta para os coordenadores pedagógicos; identificar questões essenciais sobre a elaboração, instituição e o desenvolvimento das ações do PNEGEB no Brasil, bem como, analisar como os participantes do curso de especialização em Coordenação Pedagógica percebem seus resultados.

Nesse sentido, situamos o objeto de estudo a partir do contexto mais amplo das políticas de formação para professores/gestores na atual sociedade capitalista de forma que, por meio de suas múltiplas determinações fossem apreendidas as possibilidades, limites e

\footnotetext{
1 Utilizamos a expressão "professores/gestores", considerando que a formação do gestor educacional contemporâneo no Brasil tem como fundamentos epistemológicos a formação para a docência, para a pesquisa e para a gestão democrática, como ressalta a LDB 9394/96 e as Diretrizes Curriculares Nacionais do Curso de Pedagogia (DCN-Pedagogia/2006), sendo que essas dispõem parâmetros conceituais e orientações operacionais para a formação de profissionais da educação para atuarem na educação básica, desde a creche ao ensino médio, apontando ainda as possibilidades de atuação do professor na gestão escolar.
} 
desafios da formação para coordenadores pedagógicos a partir da experiência desenvolvida no Tocantins.

Castro (2012) sinaliza que com a criação do PNEGEB, inicia-se o embrião de uma política de formação de gestores, tendo como princípios a gestão democrática e a formação em serviço por meio da educação a distância. Nesse sentido, a pesquisa se justifica por se apresentar como um estudo que busca contribuir com as discussões em torno desse Programa de formação para gestores no Brasil.

A pesquisa também se justifica entre outras questões, pelo fato de considerarmos que, em âmbito geral, as discussões referentes à formação de professores por meio da modalidade a distância no Brasil, tem sido eixo crescente de estudos, mas no que se refere à formação de gestores escolares, em especial sobre a formação de coordenadores pedagógicos, ainda são tímidas as produções em torno do tema.

Essas questões ficaram evidenciadas por meio de um mapeamento que realizamos sobre as pesquisas de mestrado e doutorado acerca do PNEGEB, em que utilizamos o Banco de Teses e Dissertações on-line da Capes.

Realizamos um levantamento das produções por meio da inserção de três descritores no campo de pesquisa do site da Capes denominado de "Busca Básica". Sobre o descritor "Escola de Gestores" obtivemos o maior número de pesquisas, com 33 registros. Desse total, dois trabalhos de mestrado tiveram como foco a Coordenação Pedagógica expressa pelo curso de especialização lato sensu, no entanto todas as outras produções analisaram o curso de especialização em Gestão Escolar do PNEGEB.

Embora esse descritor represente o maior número de registros, chama atenção porque também apresenta um quantitativo pequeno de produções sobre o PNEGEB no Brasil, considerando, por exemplo, os estudos sobre a formação de professores em que encontramos um universo de "13.516" registros sobre um descritor mais geral relacionado à "formação de professores" que inserimos no recurso de "Busca Básica" da Capes. Vemos que as 33 produções em torno do PNEGEB representam um número bem tímido de estudos sobre essa temática em relação ao número de produções sobre a formação de professores.

Em relação à seleção das produções do mapeamento sobre as pesquisas em torno do descritor "Escola de gestores", focalizamos aquelas que se aproximavam da área de conhecimento de políticas da educação, das quais buscamos evidenciar os principais enfoques de estudos sobre o PNEGEB, no sentido de obtermos elementos para a compreensão do 
concreto pensado, síntese da formação dos coordenadores pedagógicos, foco dessa pesquisa, a partir de uma visão de totalidade.

De modo geral, as pesquisas disponíveis no Banco de Dados da Capes sobre o PNEGEB, apresentaram dentre seus objetivos, a tendência predominante sobre os estudos que analisaram o curso de especialização lato sensu em Gestão Escolar, sendo apenas duas pesquisas que focalizaram o curso de especialização lato sensu em Coordenação Pedagógica como mencionamos anteriormente.

Em relação a essas duas dissertações, destaca-se a de 2012 que teve como título "O tutor presencial na educação à distância: interação entre papel, atribuição, mediação e prática pedagógica na formação continuada de professores", que foi realizada na Universidade Federal de Viçosa, no mestrado em educação. Teve como objetivo analisar as práticas pedagógicas dos tutores do referido curso.

A outra dissertação foi desenvolvida em 2015 no mestrado em Letras na área de Linguagem e Identidade da Universidade Federal do Acre (UFAcre). A pesquisa que teve como título "A Identidade Profissional do Coordenador Pedagógico da Rede Pública Estadual de Rio Branco: entre as normatizações legais e a prática cotidiana". Teve como objetivo analisar as relações existentes entre as normatizações legais do cargo de coordenador pedagógico, a prática cotidiana desse profissional e a construção de sua identidade.

Essas duas dissertações, embora fossem as únicas encontradas sobre a temática de recorte da nossa pesquisa, ou seja, sobre o curso de especialização para Coordenadores Pedagógicos, não entraram nas análises, pois não se aproximavam da área de políticas de educação.

Considerando essas questões e selecionando as produções da área de políticas da educação, o universo de pesquisas do mapeamento diminuiu ainda mais, sendo considerado um total de 14 publicações entre teses e dissertações sobre o Programa Nacional Escola de Gestores da Educação Básica no Brasil.

Assim, de forma geral, as produções analisadas a partir da leitura dos resumos e introduções dos trabalhos completos, apresentaram como objetivos a análise sobre a implantação dos cursos de pós-graduação lato sensu em Gestão Escolar e seus impactos para a formação e para a prática dos gestores.

Em relação aos principais resultados, as pesquisas apontaram que a formação continuada ofertada por esses cursos no contexto do PNEGEB foi considerada positiva. Embora o mapeamento assinale que as pesquisas apresentem resultados positivos em relação 
ao Programa, a partir da formação continuada e a distância, há pelo menos quatro delas que assinalam contradições. Mais adiante, esse ponto será retomado.

$\mathrm{Na}$ dimensão pessoal, o interesse pela temática se justifica considerando a formação inicial no curso de graduação em Pedagogia realizado na Universidade Federal de Uberlândia (UFU) no período de 2000 a 2003 e a participação em pesquisa de Iniciação Científica financiada pelo Projeto Institucional de Bolsas de Iniciação Científica (PIBIC) do Conselho Nacional de Desenvolvimento Científico e Tecnológico (CNPq).

$\mathrm{Na}$ ocasião, tivemos a primeira experiência com pesquisas a partir da realização de um mapeamento sobre a produção científica em periódicos nacionais da área da educação, que visava obter um levantamento das temáticas produzidas sobre a educação a distância no Brasil, no período de 1990 a 2000. Desde aquele momento, os estudos iniciais apontavam que a EaD vinha se configurando como uma possibilidade de atendimento das demandas de formação para os profissionais da educação, além de significar uma tendência que se fortalecia, sobretudo, na educação superior para os cursos de licenciaturas e formação continuada.

Buscando aprofundar esses estudos, em especial, sobre a educação superior no contexto do processo reformista do Estado brasileiro, desenvolvemos uma pesquisa no curso de mestrado em educação na linha de pesquisa "Políticas e Gestão da educação" da Faculdade de educação da UFU, com o foco nas formas de gestão presentes na educação superior e tendo como recorte o processo de criação e implantação Universidade Federal do Tocantins (UFT).

Pesquisas na área de políticas da educação e da $\mathrm{EaD}$ continuaram sendo nosso objeto de estudos durante nossa atuação como professora substituta em cursos de Licenciatura e depois como professora efetiva no curso de Pedagogia dessa mesma universidade, a UFT, na qual também tivemos a oportunidade de ter experiência em cursos de educação a distância.

A experiência como professora na $\mathrm{EaD}$ ocorreu nas duas ofertas do curso de especialização lato sensu em “Gestão Escolar" ofertados em 2008-2009 e em 2009-2010 e também na primeira turma do curso de especialização em Coordenação Pedagógica ofertado em 2010-2011 no âmbito do Programa Nacional Escola de Gestores.

Outras experiências como tutora em cursos de EaD também ocorreram, como no curso de Extensão e de Especialização lato sensu em "Mídias da Educação" oferecido pela UFT e apoiado pelo MEC e também tutora no curso de Aperfeiçoamento em "Diversidade Cultural", também pela UFT/MEC. Nessa função de tutoria, também participamos do curso de 
licenciatura em Pedagogia da Universidade de Brasília $(\mathrm{UnB})$ do programa Universidade Aberta do Brasil (UAB).

Além de professora e tutora em cursos de educação a distância, também destacamos nossa experiência como aluna no curso de especialização lato sensu em "Educação Continuada e a Distância”, ofertado pela Faculdade de Educação da UnB. A participação nos referidos cursos (como professora, tutora e aluna) instigou-nos a participar e publicar diversos textos e artigos em eventos da área da educação a distância e políticas da educação, dentre outras, assim como nos possibilitou organizar a produção de um livro sobre as experiências a especialização da Coordenação Pedagógica.

Em contrapartida, ao participarmos de cursos nessa modalidade como professora, tutora e aluna, ao produzir artigos e textos sobre formas de ensinar, aprender, avaliar, planejar e fazer gestão em cursos a distância, emergiu a necessidade de investigar de forma mais detalhada a respeito das políticas de $\mathrm{EaD}$ de forma a compreender as determinações dessas políticas.

A partir do olhar inicial na aparência do fenômeno, objeto dessa pesquisa, e considerando nossa inserção como professora nesse curso de pós-graduação, foi possível acompanhar o processo de formação dos profissionais e, ao mesmo tempo, formular indagações e questionamentos que nos incomodavam, sobretudo, questões relacionadas aos objetivos do curso, ao perfil de formação esperado aos egressos, às mudanças ocorridas na formação e no trabalho dos coordenadores, entre tantas outras.

A proximidade com o objeto como participante nessa condição de professora do referido curso, possibilitou a formulação das questões iniciais, levando-nos à tematização do problema de pesquisa a partir de sua materialidade na experiência desenvolvida pela UFT.

Esse curso de especialização para Coordenadores Pedagógicos teve a intenção de se tornar um auxílio aos profissionais das escolas públicas de modo que esses pudessem ampliar suas capacidades de análise e resolução de problemas, bem como, possibilitar que eles tivessem acesso a um referencial teórico e prático para que, em suas práticas diárias, pudessem desenvolver projetos e atividades no âmbito do trabalho pedagógico e do processo de ensino aprendizagem. Esses objetivos e atitudes esperadas estão associados aos dois pilares de formação do PNEGEB, que são o direito à educação e a gratuidade do ensino.

O Projeto Pedagógico do curso da UFT reconhece e afirma que a formação desses profissionais é de suma importância para o "fortalecimento da educação inclusiva e da gestão democrática na educação pública", afirmando que no Brasil há um "elevado número de 
coordenadores pedagógicos" e reforçando as possibilidades de o curso ser realizado na modalidade a distância, quando destaca que muitos desses profissionais encontram dificuldades para efetivar "uma formação continuada e pós-graduada" nas condições de um curso presencial e regular. (PPC/UFT, 2010, p.6).

Diante dessa compreensão inicial sobre o curso, algumas inquietações foram aflorando e indagamos se a formação realizada por meio do curso no Tocantins possibilitou ao profissional fazer questionamentos ao seu próprio trabalho e às suas práticas cotidianas, visando transformá-las em novas ações a partir dos conhecimentos proporcionados pelo curso, ou se o profissional que se formou acabou dominando conceitos fragmentados, desconectados de seu contexto real de trabalho.

Questionamos também, pautados em Ilma Veiga (2003) e considerando que o PNEGEB se apresenta como uma proposta de inovação ao propor cursos de pós-graduação lato sensu para professores/gestores, se o referido curso para Coordenadores Pedagógicos se apresentou como uma inovação de cunho "emancipatório ou edificante" ou se enquadrou em ações que marcam as inovações do tipo "regulatória ou técnica"?

Por "inovação regulatória ou técnica", Veiga (2003) entende que ela se refere às ações de cunho regulatório e normativo e tem suas bases na ciência conservadora que ora se caracteriza pela "observação descomprometida, pela certeza e pela quantificação dos fenômenos", ora pela não articulação e não desenvolvimento de "novas relações entre o ser, o saber e o agir”. (p.269).

Nesse sentido, as relações sociais dos indivíduos com a sociedade são desprezadas, além disso, eles não são protagonistas das inovações e nem mesmo delas se beneficiam, pois elas representam continuidade e reprodução acrítica, sendo o termo "inovação" apropriado no sentido de que o "novo" é também uma regulação em que as mudanças ocorrem "do todo pelas partes" (VEIGA, 2003, p.269). Um exemplo dado pela autora é a reforma educacional representada pela LDB 9394/96, a qual mostra:

Incitações teóricas a uma participação formal, legitimadora de um controle burocrático cada vez maior sobre as instituições educativas, os professores, os servidores técnico-administrativos e alunos. Dessa forma, as políticas públicas constrangem e orientam algumas condições de inovação. (Idem, p.269).

Por sua vez, a "inovação emancipatória ou edificante" é entendida pela autora a partir do conceito de "inovação" como sendo produção humana, tendo suas bases fundamentadas no “caráter emancipador e argumentativo da ciência emergente" (VEIGA, 2003, p.274). Dessa 
forma, as relações sociais dos indivíduos com a sociedade é fator determinante, pois eles são considerados sujeitos históricos e sociais, tendo em vista que a ciência emergente não permite dicotomias, pois ela busca "a superação da fragmentação das ciências e suas implicações para a vida do homem e da sociedade". (p.274).

A inovação emancipatória ou edificante é de natureza ético-social e
cognitivo-instrumental, visando à eficácia dos processos formativos sob
exigência da ética. A inovação é produto da reflexão da realidade interna da
instituição referenciada a um contexto social mais amplo. (VEIGA, 2003,
p.275).

Veiga (2003) discute o significado de inovação, tendo como foco o projeto político pedagógico, considerando-o a partir dessas duas perspectivas, a de uma ação "regulatória ou técnica" e a de uma ação "emancipatória ou edificante". Na primeira concepção a inovação se caracteriza por ser responsável por gerar um produto pronto e acabado, negando as diversidades e chegando ao que já era instituído, embora com novas roupagens. Trata-se de relações com caráter regulador em que o processo ocorre de fora para dentro, padronizado, uniforme, normativo, a partir do controle burocrático, causando mudanças, mas de forma temporária e parcial, pois as decisões já estavam estabelecidas.

$\mathrm{Na}$ segunda concepção, a autora destaca que a inovação gera o produto no processo, provoca rupturas chegando a novas ideias e práticas, pois é uma produção humana, portanto é também histórica e social. Há o caráter da coletividade em que as particularidades e singularidades são essenciais no processo de construção de um produto inovador.

Concordamos com Veiga (2003) e consideramos que essa segunda perspectiva deve ser alcançada pelos cursos de formação de professores/gestores. As primeiras determinações se mostravam implícitas nos documentos de criação do PNEGEB e documentos do curso lato sensu para os CP (da UFT e do MEC) e também pelas vozes dos egressos expressas em suas respostas aos questionários aplicados, quando apontam que suas práticas foram mudadas após realização do curso.

Por outro lado, compreendíamos que era necessário continuar fazendo questionamentos numa perspectiva de inquirição sobre os dados levantados, pois tendo em vista a natureza do curso de pós-graduação lato sensu, fazia-se necessário compreender sobre: Quais seriam essas práticas? Como elas eram materializadas nas funções dos coordenadores? Inquietávamo-nos em saber: Elas possibilitaram mudanças para práticas sociais de forma a romper com as práticas instituídas nas escolas? Qual a eficácia das evidências confirmadas? Qual auxílio o curso havia fornecido para as práticas cotidianas desses profissionais? Será que 
os novos saberes relacionavam possibilidades de novas ações técnicas para as mesmas tarefas diárias, sem romper ou levar à transformação de novas reflexões para fazer e produzir práticas diferentes?

$\mathrm{Na}$ medida em que esses questionamentos foram ganhando amplitude e as análises sendo realizadas, outras questões iam se somando a essas: quais teriam sido os benefícios e desafios do curso para a formação e para o trabalho diário dos CP? Os profissionais conseguem desenvolver uma gestão mais democrática em suas escolas de modo a desenvolver a inclusão social e a emancipação humana? Esse curso, por meio do PNEGEB, consolidou-se, no Tocantins, como uma ação de inovação reguladora ou técnica ou emancipadora e edificante?

A partir dessas questões, o problema de pesquisa se organizou em torno do questionamento sobre: quais seriam as determinações da política de formação para professores/gestores no Brasil no contexto do PNEGEB e como elas se expressam na experiência do curso de especialização lato sensu para Coordenadores Pedagógicos, desenvolvido pela UFT e seus parceiros no estado do Tocantins?

\section{Abordagem Metodológica}

Consideramos que o objeto de estudo e sua realidade fazem parte de uma totalidade complexa, com movimento e contradições e que se apresenta como um potencial para produção de conhecimento.

Nesse sentido, a compreensão sobre os determinantes da política de formação para professor/gestores, considerou a dimensão micro, pela experiência do curso em Coordenação Pedagógica no Tocantins e, ao mesmo tempo, as dimensões macro das quais o objeto faz parte e é constituído.

Essa compreensão não nega as condições concretas vividas, a totalidade histórica, bem como o movimento e as contradições próprias da realidade pela qual estão inseridos o objeto e os sujeitos envolvidos. Assim, a construção do conhecimento científico, parte do mais abstrato para o mais concreto, pois o todo ganha sentido significativo por meio das partes, o individual e o particular que existe na conexão com o universal.

Tomamos a categoria da contradição como referencial que está diretamente ligada à questão da dialética e da totalidade, pois só haverá contradição se houver movimento. Triviños (2012) a considera como a categoria fundamental do materialismo dialético, pois ela se apresenta na realidade objetiva, refere-se ao conteúdo da lei da unidade dos contrários, a 
Lei da Contradição (luta entre contrários que se excluem) e ainda: estabelece "interação"; "distingue os tipos de contradições"; "determina o papel e a importância que ela tem na formação material"; e "ressalta que a categoria da contradição é a origem do movimento e do desenvolvimento". (p.54).

Mason (2012) também pontua que a Contradição é capaz de promover o movimento que leva à transformação dos fenômenos. "O ser e o pensar modificam-se na sua trajetória histórica movidos pela contradição, pois a presença de aspectos e tendências contrários contribui para que a realidade passe de um estado qualitativo a outro" (p.5).

Esse é um princípio básico do materialismo dialético, é o que distingue da concepção dialética idealista e metafísica da realidade, pois "a fonte do desenvolvimento das formações materiais está em seu interior" como lembra Triviños (2012) e, portanto, é a partir das contradições internas, a partir de suas condições opostas que eles se complementam. O autor ressalta, por exemplo, que seria impossível pensar na existência da burguesia sem a presença do proletariado e, ao mesmo tempo, é a primeira a mais privilegiada por ser proprietária dos meios de produção.

Como nosso objetivo geral foi compreender as determinações das políticas de formação de professores/gestores expressas na experiência de formação no Tocantins e, tendo como base as vozes dos egressos, desenvolvemos esta investigação considerando sua dimensão histórica no contexto econômico e social, buscando situar o problema de estudo por meio da necessidade de conhecer e interpretar a realidade a partir de suas raízes em suas múltiplas relações sociais.

Para isso, partimos da aparência de como o curso de especialização lato sensu no âmbito do PNEGEB se apresenta e que está expresso nos discursos documentais, e o colocamos em relação com as vozes dos participantes (egressos, professores e gestor) visando entender a sua essência por meio de questionários, por termos considerado esse instrumento mais viável pelo tempo que tínhamos.

Considerando as indagações constantes ao longo da pesquisa, bem como o problema e os objetivos, realizamos a pesquisa bibliográfica e documental, associando com o procedimento de aplicação de questionários.

A pesquisa bibliográfica se desenvolveu durante o processo de pesquisa em variados momentos e representou um auxílio para a compreensão e construção de referenciais sobre o Estado, na compreensão sobre o sujeito, objeto da pesquisa, que se refere ao coordenador pedagógico, de modo que foi possível reunir elementos teóricos sobre as origens de sua 
função, as mudanças dela ao longo da história da educação e apreensão sobre as marcas que esse profissional carrega e que muitas vezes o impedem de refletir sobre sua identidade e de desenvolver práticas que possam contribuir para a função social da escola.

A pesquisa bibliográfica também foi fundamental para traçarmos uma compreensão em torno da educação a distância, modalidade de educação utilizada nos cursos do PNEGEB e foco das políticas de educação dos governos brasileiros nos últimos anos, a qual vem representando uma das possibilidades de se viabilizar o acesso de vagas e a garantia de formação dos profissionais da educação.

Também utilizamos esse tipo de pesquisa para a compreensão das produções científicas sobre o PNEGEB no Brasil, a partir da realização de um mapeamento realizado no Banco de Teses e dissertações da Capes, considerando as pesquisas de mestrados e doutorados que tomaram esse tema como eixo de seus estudos.

A pesquisa bibliográfica se utiliza da contribuição de vários autores e fontes sobre determinado assunto. É um procedimento usado em quase todo tipo de investigação e pode ser desenvolvido em todas as fases da pesquisa, à medida que se faz necessário o movimento de análise e síntese do objeto de estudo. Sua finalidade, como aponta Pádua (2004), é “colocar o pesquisador em contato com o que já se produziu e registrou a respeito do seu tema de pesquisa”. (p. 56).

Dentre suas vantagens, destaca-se, de acordo com Gil (2012), que ela permite ao investigador ter acesso a uma ampla "cobertura de fenômenos" das quais não se teria acesso de forma direta. Assim como para os estudos históricos, para os quais se pode contar com fontes secundárias, mas alerta o autor que, ao tomar contato com essas fontes, o pesquisador possa se assegurar "das condições em que os dados foram obtidos, analisar em profundidade cada informação para descobrir possíveis incoerências ou contradições”. (GIL, 2012, p.50$51)$.

Realizamos também a pesquisa documental, cuja base empírica se pautou em fontes primárias sobre a criação do PNEGEB no Brasil e sobre o curso de especialização ofertado pela UFT, destacando-se entre os documentos o: Projeto Básico: Escola de Gestores (2004); Diretrizes do PNEGEB (2009); Projeto Pedagógico do Curso (MEC, 2009); Projeto Pedagógico do Curso (UFT, 2010); Relatório Final do Curso (UFT, 2012), Relatório de Avaliação do Curso (UFT, 2012), além dos editais de seleção (UFT, 2010).

A pesquisa documental se apresenta importante, tendo em vista que, por meio dela, o pesquisador se apoia em documentos e fontes primárias que ainda não foram manuseados e, 
como destaca Gil (2012), "vale-se de materiais, que ainda não receberam tratamento analítico" (p.51), ou também por dados secundários desde que sejam considerados confiáveis para a realização da pesquisa.

Esse autor destaca que as fontes documentais são capazes de "proporcionar ao pesquisador dados em quantidade e qualidade suficiente para evitar a perda de tempo e constrangimentos" (p. 51), referindo-se às pesquisas que a coleta de dados faz referência às pessoas. Além dessas vantagens, destaca-se o fato de que possibilita o conhecimento do passado, a investigação de processos de mudanças sociais e culturais e facilita a obtenção de dados com menor custo.

Com relação ao que se considera como documento, o autor ressalta:

Para fins de pesquisa científica são considerados documentos não apenas os escritos utilizados para esclarecer determinada coisa, mas qualquer objeto que possa contribuir para a investigação de determinado fato ou fenômeno. Assim, a pesquisa documental tradicionalmente vale-se dos registros cursivos, que são persistentes e continuados. Exemplos clássicos dessa modalidade de registro são os documentos elaborados por agências governamentais. Mas muitas pesquisas utilizam registros episódicos e privados, constituídos principalmente por documentos pessoais e por imagens visuais produzidas pelo meio de comunicação de massa. (GIL, 2012, p.147).

Também selecionamos alguns documentos de publicações do Banco Mundial e da Unesco, buscando compreender os principais elementos e características de suas diretrizes para a formação de profissionais da educação e para a gestão escolar.

Esses documentos sugerem na sua aparência, a partir das Políticas Oficialmente Declaradas (POD), consensos e ideias que não são a expressão das Políticas de Fato (POF). Portanto, é necessário "fazer sangrar a fonte", como coloca Evangelista (2012), no sentido de que possamos compreender o que não está dito, o que elas silenciam, perguntando-lhes o que "oculta e o porquê oculta". (p.10).

Considerando essa perspectiva propomos uma compreensão dos documentos sobre políticas públicas a partir de uma perspectiva de distinção entre as POD e as POF, Políticas Oficialmente Declaradas e as Políticas de Fato, baseando-se na dinâmica utilizada por Bastos (2014) em seu estudo sobre um determinado documento do Banco Mundial, pela qual ele visava desvelar o efetivo papel desses OIs.

Considerando as dificuldades de se identificar, à primeira vista, os interesses reais de uma determinada política, essa perspectiva auxilia no sentido de fazermos a distinção entre as POD, aquelas políticas descritas, anunciadas, refletidas nos textos e documentos, desenhadas 
por meio de consensos e as POF, aquelas políticas refletidas e materializadas pelas ações das primeiras. Bastos (2014) reconhece que a primeira distinção é “ambígua, além de potencialmente parcial e viciada" e a segunda, são políticas que "muitas vezes contradizem as políticas oficialmente declaradas pela instituição”. (p.4).

Essa dinâmica apresenta-se coerente ao movimento adotado na pesquisa e não tem a intenção de ser uma proposta teórica e metodológica para a análise de políticas públicas, pois reconhecemos seus limites e fundamentos. No entanto, foi utilizada como uma possibilidade de compreensão sobre os documentos analisados.

Retomando ao que Evangelista (2012) coloca sobre os documentos, sabemos que a sua escolha como fontes de pesquisa é fundamental, mas reconhecemos que não é possível ter o acesso a todas as fontes existentes sobre o assunto estudado. Nesse sentido, a escolha das fontes analisadas esteve associada à intenção da investigação, como pontua Evangelista (2012): “Sendo impossível ter acesso a todos os documentos que se relacionam ao tema, é fundamental que se possa encontrar e conhecer os que o determinam historicamente e sem os quais a pesquisa não avança em direção ao conhecimento". (p. 5).

A autora destaca a importância do trabalho com documentos, pois esses são construídos pela história que, por sua vez, constrói-se nas relações sociais concretas. Assim, ela ressalta que é impossível "qualquer investigação que passe ao largo dos projetos históricos que expressa". (p.3). Nessa perspectiva, considera que a empiria é gestada na história e essa representa a manifestação da consciência humana na história:

[...] todos os documentos são importantes, em graus diferenciados, e expressam determinações que estão no cerne do corpus documental. Entretanto, isto não é dado na fonte em si; é necessária uma reflexão de largo espectro - uma decomposição da fonte, uma separação entre essência e aparência - para que a sua vida seja trazida à tona. Pressupondo-se que os documentos - incompletos e imperfeitos - estejam em mãos do pesquisador - nos limites que a história impõe para sua localização e acesso - tem início sua "inquirição" para entender-se quando, como, por quem e por que foram produzidos. (EVANGELISTA, 2012, p.6 e 8). (grifos da autora).

Nessa perspectiva, corroboramos a autora quando ressalta que é necessário captar as múltiplas determinações da fonte e da realidade em que foi produzida, ou seja, "captar os projetos litigantes e os interesses que os constituem" (p.8). É necessário dialogar com as fontes, com seu marco histórico e real e, nesse caso, o aporte teórico adotado na pesquisa se torna fundamental, pois ele concretiza a possibilidade do diálogo com as fontes e a teoria. Essas mediações levam à apreensão do real a partir das aproximações com a sua totalidade. 
Documentos "oficiais e oficiosos", para Evangelista (2012), são produzidos por indivíduos representantes de instituições do aparelho do Estado e expressam "não apenas diretrizes para a educação, mas articulam interesses, projetam políticas, produzem intervenções sociais". (p.2).

Ademais, é preciso captar a constituição de determinada moral e concepção de mundo de modo a envolver questões de ordem cultural visando a alcançar um "acordo coletivo" na medida em que a mensagem simbólica é introduzida, "produzindo consciências falantes, sujeitos que sentem a vivência ideológica como sua verdade”. (COSTA, 2016, p.3).

Para Costa (2016), na medida em que isso ocorre, desenvolve-se também uma ação prática, que é prática social, ou a práxis: “O pensamento político e ideológico, dessa forma, apresenta-se como uma realidade prática, porque, ao ser compreendido e aceito pelos atores, torna-se poder material, converte-se em ação prática, ou mais precisamente, em práxis”. (p.3).

Nesse processo de compreensão do objeto na sua dimensão de totalidade, realizamos a aplicação de questionários de forma a compreender a visão dos participantes do referido curso de especialização em relação às diretrizes políticas do programa.

Com relação ao uso de questionário, Pádua (2004) destaca que ele é um tipo de coleta de dados em que os informantes preenchem o instrumento, formulário de perguntas elaboradas pelo pesquisador. Embora seja um instrumento muito usado para quantificação dos dados, Triviños (2012) lembra que esse, como qualquer instrumento usado para a coleta de dados, pode ganhar vida a partir da iluminação teórica que o pesquisador lhe dará.

Gil (2012) aponta algumas desvantagens do uso de questionário, por exemplo, o fato de reduzir possibilidade de compreensão do informante, uma vez que o pesquisador não estará presente para fazer explicações ou ainda porque não oferece garantias de que a maioria das pessoas responderá o questionário.

Por outro lado, a aplicação de questionário apresenta vantagens como destacam Marconi e Lakatos (2007), pois “economiza tempo, viagens e obtém grande número de dados; obtém respostas mais rápidas e mais precisas; obtém respostas que materialmente seriam inacessíveis". (p. 203-204).

Além disso, o questionário constituiu-se em um importante instrumento para a pesquisa, considerando o fator tempo, economia e acesso há um grande número de participantes. No nosso caso, tornou-se fundamental considerando que não teríamos possibilidade de manter contato físico com os participantes, tendo em vista que o curso foi desenvolvido há mais de quatro anos. 
Assim, utilizamos a técnica de Survey, como uma estratégia de examinar uma amostra de certa quantidade de pessoas, como destaca Ramos (2011), para "obter dados ou informações a respeito de opiniões (conceitos, paradigmas), ações ou características de uma determinada população, para tanto, seleciona uma população alvo, a qual é a amostra" (p.33).

Dentre algumas de suas vantagens, tem-se a capacidade de generalização de uma população inteira a partir de uma amostra, considerando uma situação em que, quando o objeto da pesquisa decorre de algo que se instala no presente ou no passado recente, nem sempre se tem o contato com todos os sujeitos para a investigação.

Embora haja limites quanto ao uso do instrumento questionário, quando utilizado contando com recursos de comunicação digital, por meio do envio de correio eletrônico - $e$ mail, e usando ferramentas on-line do questionário Survey, ele se apresentou coerente para essa pesquisa.

O questionário aplicado foi elaborado utilizando um formulário on-line disponibilizado gratuitamente pela plataforma Google Docs. Foi elaborado considerando uma parte específica para cada categoria de participantes, sendo eles os cursistas, os professores e o gestor do curso, e uma parte comum a todos eles.

A parte específica foi organizada por meio de questões fechadas em que os participantes deveriam escolher e marcar a alternativa que mais se aproximava às suas opiniões, sendo que algumas questões tinham a opção "Outros" em que o participante poderia escrever livremente sua opinião. A parte comum do questionário foi organizada utilizando a escala do tipo Likert por meio de uma série de cinco proposições com o grau de concordância entre: 1 - Concordo Plenamente; 2 - Concordo; 3 - Indiferente; 4 - Discordo; 5 - Discordo Plenamente.

Buscamos de forma geral, evidenciar informações mais gerais sobre quem era o participante, bem como compreender de forma mais específica a opinião deles sobre desenvolvimento do curso e os principais resultados.

Importante destacarmos que na proposta inicial de coleta dos dados pretendíamos fazer entrevistas com alguns participantes do curso (a partir de uma seleção de ex-alunos por polos em que foi ofertado o curso). No entanto, dada à dinâmica da pesquisa e considerando as dificuldades de acesso a esses sujeitos, utilizamos apenas o questionário conforme especificado.

O questionário inicialmente foi encaminhado para os endereços eletrônicos de e-mails dos 299 egressos concluintes do curso de especialização lato sensu em CP, bem como para os 
35 professores e para os dois gestores. Foram enviados o convite e o link do questionário no período de novembro de 2015 a dezembro de 2015 em que solicitamos a contribuição da participação desses atores na pesquisa.

Após um mês de envio das mensagens, não havíamos obtido o retorno de nem $5 \%$ dos participantes. Percebemos que os endereços eletrônicos informados em 2009 na época de ingresso ao curso, já estavam desativados. O passo seguinte foi fazer contato por telefone, utilizando o aplicativo do WhatsApp Messenger, de mensagens multiplataforma que permite trocar mensagens em tempo síncrono e de forma gratuita.

Paralelo ao processo de busca de contatos por esse aplicativo, também utilizamos a rede social do facebook de modo a atualizar os contatos dos participantes, enviando o convite de participação à pesquisa, bem como o link do questionário. Fizemos o monitoramento sobre o recebimento das mensagens e, a cada dois dias, reenviávamos novas mensagens reiterando o convite para a participação, sobretudo dos egressos.

Essas ações auxiliaram para a obtenção de um retorno mais rápido, pois à medida que conversávamos com os participantes, explicávamos dúvidas, mantínhamos um contato mais próximo, o que certamente serviu de sensibilização para que eles respondessem ao questionário.

Após incessantes contatos e depois de quatro meses de tentativas, conseguimos a participação de 82 egressos, o que representa um total de $28 \%$ dos respondentes. Dos 35 professores que atuaram no curso, conseguimos a participação de 13 deles que responderam ao questionário, o que corresponde a $37 \%$ dos respondentes.

Também aplicamos questionários aos dois gestores gerais do curso, sendo que tivemos o retorno de um deles. Em todos os casos, trabalhamos com um quantitativo superior a 25\%, um mínimo desejável para respostas de questionários conforme aponta Marconi e Lakatos (2007).

Ao procedimento de análise dos dados, pautamo-nos na referência de Fiorin (2005), para quem a linguagem, ao mesmo tempo em que sofre influência de determinações sociais, também possui certa autonomia sobre elas. Para compreendê-la é preciso estabelecer relações entre elas.

Nesse sentido, o texto, para o autor supracitado, representa o "lugar de manipulação consciente, em que o homem organiza, da melhor maneira possível, os elementos de expressão que estão a sua disposição para veicular seu discurso. O texto é, pois, individual, enquanto o discurso é social". (p.44). Em outro ponto, acrescenta ainda que o "discurso é, 
pois, o lugar das coerções sociais, enquanto o texto é o espaço da 'liberdade' individual". (p.45).

O autor aponta que a "análise do discurso vai, à medida que estuda os elementos discursivos, montando por inferência a visão de mundo dos sujeitos inscritos no discurso. Depois, mostra o que é que determinou aquela visão nele revelada". (p.83). Nessa perspectiva, a análise dos textos não deve ficar na fase da descrição ou desvelamento da metáfora utilizada para explicar uma ordem social, mas também precisa revelar elementos ideológicos que traduzem concepções de mundo de determinada classe. (FIORIN, 2005).

A partir desse referencial, compreendemos que a análise dos documentos oficiais do curso para $\mathrm{CP}$, bem como as vozes dos participantes dessa pesquisa inseridas na política do PNEGEB, precisam ser entendidas para além da manifestação expressa na primeira aparência, ou seja, das primeiras análises e das percepções sobre as respostas dadas aos questionários, pois é preciso considerar o lugar de onde falam, a posição que ocupam o sujeitos, assim como compreender de qual é o espaço histórico, social e político pelos quais os documentos foram elaborados e colocados em prática.

Assim, o texto e o contexto da criação do PNEGEB e do curso para CP tratam-se de um conjunto de ações com finalidades e sentidos políticos próprios e, que, portanto, precisavam ser apreendidos a partir da prática estabelecida no curso, considerando a esfera local no estado do Tocantins, pois os processos de concretização da linguagem estabelecidos pelos documentos oficiais ganham novos significados e sentidos quando materializados pelas percepções dos sujeitos da pesquisa.

Nesse sentido, é importante termos claro o conceito de ideologia utilizado nesta pesquisa, tendo em vista as possibilidades de apreendê-la nos documentos e nas visões dos participantes. Assim, adotamos o conceito de ideologia a partir da perspectiva marxiana.

Na obra "Ideologia Alemã", Marx e Engels (2009) apontam que "quase toda Ideologia se reduz ou a uma concepção deturpada dessa história ou uma completa abstração dela". (p.21). Em outra passagem dessa obra, em que os autores fazem críticas aos jovens hegelianos, vemos esse conceito de ideologia entendido como a visão das relações sociais de forma invertida.

Marx e Engels (2009) identificam esses jovens hegelianos como os primeiros ideólogos e os maiores conservadores por se preocuparem mais com a luta contra conceitos, "frases", celebrando como sendo legítima a crença no domínio da religião, considerando as 
"representações, ideias, conceitos", mas tudo isso era produto da consciência deles, pois não as enxergavam como sendo produto das relações na sociedade.

Para os autores, o homem está ligado às condições materiais de existência, ou seja, as condições reais em que a vida humana se desenrola. Se, portanto, a ideologia é vista de forma invertida, é porque não se está percebendo a realidade das coisas tal como elas de fato são.

Os homens são os produtores das suas representações, ideias, etc, mas os homens reais, os homens que realizam, tal como se encontram condicionados por um determinado desenvolvimento das suas forças produtivas e pelas relações que a estas correspondem até suas formulações mais avançadas. A consciência nunca pode ser outra coisa senão o ser consciente, e o ser dos homens é seu processo real de vida. Se em toda ideologia os homens e suas relações aparecem de cabeça para baixo como numa câmera escura, é porque esse fenômeno deriva do seu processo histórico de vida da mesma maneira que a inversão dos objetos na retina deriva do seu processo diretamente físico de vida. (MARX, ENGELS, 2009, p.31). (grifos nossos).

A ideologia é também e quase sempre, uma distorção da consciência, da história, da vida real, o que é contrário à perspectiva dos hegelianos, de que a ideologia é a própria consciência. O homem é esse ser real como destaca Marx, o homem que se realiza e que é capaz, por meio da consciência, de se transformar em um ser consciente no percurso de seu processo histórico.

No entanto, mesmo considerando que o homem possui, desde sua existência uma consciência, é necessário compreender a diferença que existe de uma consciência de si e de uma consciência para si. A primeira refere-se a uma consciência individual, de si para si próprio e a segunda trata da consciência que considera a totalidade das classes sociais e históricas, e só ocorre quando há a passagem da consciência individual para consciência de classe, em que os indivíduos saem da condição egoísta para uma posição altruísta em que buscam a emancipação de forma consciente.

Nesse sentido o termo "Consciência" é mais amplo do que a "Ideologia" e só por meio daquela é que se consegue romper com essa, ou seja, só quando os indivíduos tiverem consciência para si, coletiva, é que conseguirão romper com as ideologias, pois "não é a consciência que determina a vida, é a vida que determina a consciência” (p.32).

Húngaro, (2014) ressalta que:

Ao não se perceber que é a vida que determina a consciência, tem-se o domínio da ideologia, do pensamento que não reconhece os seus determinantes. E é através da ideologia que se gesta uma falsa representação dos processos sociais. Falsa porque ao desconhecer sua relação com a base 
material da sociedade, o pensamento se autonomiza - não só não reconhece suas determinações como julga que o processo da base material é por ele originado. (p.61).

Antônio Severino (1986) lembra que Marx não chegou a explicitar sua concepção de ideologia em termos de um "esquema teórico", mas trabalhou com o termo a partir da análise da ideologia da burguesia de sua época, destacando que "toda a cultura ocidental dos últimos séculos se constitui num corpo que serve para camuflar os reais interesses da classe burguesa, ao mesmo tempo em que pretende apresentá-lo com sendo explicação verdadeira do mundo, como interesse de todos os homens." (p. 10).

Esse autor destaca o conceito de ideologia na perspectiva marxiana considerando o pressuposto que "todas as formas de pensamento e de representações, elaboradas pela consciência humana" que se caracterizam por um conjunto de crenças é chamado de ideologia. Trata-se de formas da consciência que não representam a realidade objetiva dos fatos, mas apenas certa expressão predeterminada por uma classe dominante. Isso é cada vez mais agravado com o aumento da divisão do trabalho, pois com ele há um distanciamento entre a "esfera social e a esfera da consciência" e, ao mesmo tempo, isso expressa que esses conceitos são universais, por meio de certo “poder misterioso". (SEVERINO, 1989, p.8).

Nessa perspectiva, o autor ressalta um aspecto da visão de ideologia, a partir da falsa consciência, em que, no plano da consciência, ela serve para "mascarar a realidade fundamental, que é de natureza econômica" (p.8), sendo que, os que dominam o poder a utilizam para ocultar seus verdadeiros propósitos e não deixar claro suas intenções de dominação. Nesse sentido, sintetiza o autor que:

[...] a ideologia é toda forma de pensamento teórico, cujo conteúdo se constitui de representações ilusórias do real objetivo, apresentadas como correspondendo aos interesses universais, mas correspondendo de fato aos interesses particulares das classes sociais e elaboradas com a finalidades de justificar o exercício do poder político sobre as outras classes ou grupos em decorrência do exercício do poder econômico fundado no domínio da propriedade privada. (SEVERINO, 1986, p. 10). (grifos nossos).

Por sua vez, Gramsci (1999) também se refere ao conceito de ideologia e, embora seja um autor marxiano, refere-se ao termo não numa visão negativa, mas como uma concepção de mundo que se manifesta em todas as atividades da vida individual e coletiva, sendo ele um elemento definidor e constituidor do movimento real. Essa é mais uma de suas contribuições ao marxismo em termos de superação como apontam Brandão e Dias (2007). 
Nessa perspectiva gramsciana, a ideologia refere-se a uma experiência que é materializada nas práticas dos indivíduos e seus grupos, do seu bloco social, ou seja, do sujeito coletivo. São, portanto, ideologias orgânicas, as quais “"organizam” as massas humanas, formam o terreno no qual os homens se movimentam, adquirem consciência de sua posição, lutam etc”. (GRAMSCI, 1999, p.273).

Para a filosofia da práxis, as ideologias não são de modo algum arbitrárias; são fatos históricos reais, que devem ser combatidos e revelados em sua natureza de instrumentos de domínio, não por razões de moralidade, etc., mas precisamente por razões de luta política: para tornar os governados intelectualmente independentes dos governantes, para destruir uma hegemonia e criar uma outra, como momento necessário da subversão da práxis. (GRAMSCI, 1999, p.392).

Por sua vez, essa ideia é original de Marx e Engels, tendo em vista que eles já apontavam na "Ideologia Alemã” que "As ideias da classe dominante são, em todas as épocas, as ideias dominantes, ou seja, a classe que é poder material dominante da sociedade é, ao mesmo tempo, o seu poder espiritual dominante.” (MARX, ENGELS, 2009, p.67). (Grifos dos autores). Em outra parte do texto, destaca-se: "Toda essa aparência de que o domínio de uma determinada classe seria apenas o domínio de certas ideias cessa, naturalmente, por si mesma logo que o domínio de classes em geral deixa de ser a forma da ordem social”. (p.70).

Brandão e Dias (2007) argumentam que Gramsci aprofunda esse sentido de ideologia marxiana e o associa a compressão de hegemonia, pois se ideologia se refere a uma visão de mundo, a hegemonia tratará da construção dessa visão e, portanto, são elementos importantes para se pensar a realidade social e para se alcançar a emancipação dos indivíduos.

A filosofia da práxis, ao contrário, não tende a resolver pacificamente as
contradições existentes na história e na sociedade, ou, melhor, ela é a própria
teoria de tais contradições; não é o instrumento de governo de grupos
dominantes para obter o consentimento e exercer a hegemonia sobre as
classes subalternas; é a expressão destas classes subalternas, que querem
educar a si mesmas na arte de governo e que têm interesse em conhecer
todas as verdades, inclusive as desagradáveis, e em evitar os enganos
(impossíveis) da classe superior e, ainda mais, de si mesmas. (GRAMSCI,
1999, p.393).

Tendo em vista que nossa proposição de tese pretende analisar documentos de OIs de modo a apreender seus discursos ideológicos, temos que a pesquisa também busca investigar se as diretrizes do PNEGEB caminharam nas perspectivas desses OIs ou se mostrou contra hegemônica a sua direção a partir da experiência do curso no Tocantins. 


\section{Visão Geral da Pesquisa}

A forma de exposição da pesquisa foi organizada além do texto da Introdução da tese e das Conclusões, em duas partes compostas por capítulos. Essa dinâmica se apresentou coerente tendo em vista as especificidades próprias apresentadas em cada texto durante sua elaboração.

Assim, na Parte I, denominada: "Referencial Teórico", situamos as abordagens dos apítulos I, II e III. O primeiro Capítulo foi denominado de "Concepções e Desenvolvimento do Estado no Mundo Contemporâneo" e teve como além de aprofundar sobre conhecimentos teóricos e conceituais, destacar elementos que possibilitem a compreensão sobre a relação das características, gênese e desenvolvimento do Estado, com sua influência e impactos na formulação e execução de políticas públicas, face aos acontecimentos históricos, políticos e sociais que, por sua vez, são marcados por interesses predominantemente econômicos.

O segundo Capítulo foi intitulado de "Agências Internacionais e os Consensos para as Reformas na Educação" e nele foram destacadas características em torno das origens dos Organismos Internacionais, suas funções bem como suas diretrizes e orientações para as reformas administrativas e educacionais.

Ainda nessa Primeira Parte da tese, temos o terceiro Capítulo com o título "Educação a Distância e os Organismos Internacionais". Nele, desenvolvemos uma discussão a respeito da Educação a distância partindo da concepção de educação crítica de forma a compreendermos as possibilidades e os limites dos cursos desenvolvidos nessa modalidade, tendo em vista seus vínculos com os OIs.

Na Parte II da tese, denominada de "Referencial Empírico", situamos as discussões desenvolvidas nos Capítulos IV e V. No Capítulo IV, intitulado de "O Programa Nacional Escola de Gestores da Educação Básica - Ação das Políticas de Formação de Gestores Escolares", apresentamos as origens e as principais características do Programa, assim como algumas características do curso de especialização latu senso em Coordenação Pedagógica desenvolvido no Tocantins pela UFT e seus parceiros e associado a essas discussões, apresentamos o resultado de um mapeamento sobre as produções de pesquisas de mestrado e doutorado disponíveis no portal de Teses e Dissertações da Coordenação de Aperfeiçoamento de Pessoal de Nível Superior (CAPES), sobre o PNEGEB no Brasil.

No Capítulo V, que denominamos de "Visões dos participantes do Curso de Especialização em Coordenação Pedagógica", pontuamos as análises sobre o que os 
participantes da especialização em Coordenação Pedagógica pensam sobre o desenvolvimento e o resultado do curso, com a intenção de desenvolver melhor aproximação com o objeto de investigação, de modo articulado com os conceitos desenvolvidos na parte I.

Por fim, esperamos contribuir com as discussões sobre políticas públicas de educação, sobretudo as de educação a distância direcionadas à formação de professores/gestores escolares, para coordenadores pedagógicos, visando ampliar e aprofundar a produção científica e crítica sobre o assunto. 
PARTE I - Referencial Teórico 


\title{
CAPÍTULO I - CONCEPÇÕES E DESENVOLVIMENTO DO ESTADO CONTEMPORÂNEO
}

\author{
Assim, a primeira coisa a fazer em qualquer \\ concepção da história é observar esse fato \\ fundamental em todo o seu significado e em toda a \\ sua extensão e atribuir-lhe a importância que lhe é \\ devida.
}

Marx, Engels, 2009.

\subsection{Apontamentos Iniciais do Capítulo}

Neste capítulo, não temos a intenção de fazer um resgate histórico e detalhado acerca das teorias e origens do Estado moderno, nem mesmo de apresentar seu percurso de constituição e formação de forma pormenorizada.

Interessa-nos compreender, a partir de uma revisão bibliográfica, alguns elementos que se mostram importantes nesse processo por serem marcados por múltiplas determinações que, certamente, auxiliam na compreensão do objeto de estudo da tese proposta.

O objeto de pesquisa, o curso de formação de coordenadores pedagógicos no Tocantins a partir da oferta de especialização lato sensu pela UFT e seus parceiros, apresentase como uma política pública formulada pelo Estado na sua concepção mais atual, de Estado neoliberal.

Nesse sentido, o objetivo desse capítulo é, além de aprofundar sobre conhecimentos teóricos e conceituais, destacar elementos que possibilitem a compreensão sobre a relação das características, gênese e desenvolvimento do Estado, com sua influência e impactos na formulação e execução de políticas públicas, face aos acontecimentos históricos, políticos e sociais que, por sua vez, são marcados por interesses predominantemente econômicos.

É notável como a instituição "Estado" vem passando por profundas transformações, pois acompanha as mudanças que ocorrem nas formas de produção no âmbito mundial, sobretudo quando nos deparamos com as situações das consequências de guerras, de crises e imposição de novas formas de organização social e global, o que tem gerado muitas discussões sobre o real papel do Estado. 
No momento atual, vivenciado pela nova ordem mundial por meio do poderio econômico das grandes nações e interesses privados, vemos que o poder e a representatividade dos Estados têm sido questionados. Nesse sentido, para compreendermos a influência do Estado na formulação de políticas públicas de educação, resgatamos as contribuições de pensadores na história que, à sua forma e a seu tempo, muito contribuíram sobre a compreensão da constituição e caracterização do Estado para a atualidade contemporânea.

Com as mudanças no papel do Estado, suas funções de provedor de políticas sociais têm sido cada vez mais tímidas e omissas. Nesse sentido, é preciso compreender o objeto de discussão inserindo-o no contexto mais amplo das concepções de Estado, já que esse deveria ser o maior responsável pela formulação dessas políticas.

Compreendemos que as políticas públicas, como é o caso da política para formação de professores/gestores, expressa pelo curso de especialização em questão, sendo uma política social, não deve ser pensada e executada numa perspectiva isolada ou submissa aos interesses políticos, sociais e econômicos que modelam o Estado.

Concordamos com Azevedo (2001) quando afirma que uma política de educação, entendida como política social pode ser analisada a partir de algumas dimensões que considerem suas particularidades como as estruturas de poder e dominação, tendo o Estado como referência, cuja memória direciona as relações com as representações sociais desenvolvidas pelas sociedades e, ainda, porque a complexidade do seu papel e intervenção ou não dele culmina com a implementação das políticas públicas.

Assim, compreender a ação do Estado como responsável pela formulação de políticas torna-se um caminho importante, pois visões diferentes de Estado e de sociedade geram visões e objetivos diferentes de políticas públicas. É nesse sentido que esse capítulo foi construído, tendo em vista que a gênese e reestruturação do Estado têm base, sobretudo, a partir do desenvolvimento do capitalismo.

Essa compreensão tem como base o conceito de políticas públicas como sendo o "Estado em ação", adotado por Höfling (2001), em que o Estado é responsável pela promoção das políticas sociais, como é o caso da educação, por meio de ações e programas, assumindo um projeto de governo de um determinado período histórico.

É importante ressaltar, contudo, que existem várias interpretações e concepções teóricas a respeito do Estado. Optamos pela dimensão social e política, com base nas 
referências sugeridas por Dallari (1998) de que a origem do Estado pode ser compreendida a partir de sua época de criação e dos motivos de sua criação.

Com relação à época de criação, Dallari (1998) aponta pelo menos três posições fundamentais de acordo com teóricos do Estado. Uma primeira é a de que o "Estado e a sociedade sempre existiram"; outra de que a "sociedade humana existiu sem o Estado durante certo período" e uma última posição é a daqueles que admitem o Estado como a "sociedade política dotada de certas características muito bem definidas" (p.22), ou seja, a figura do Estado como conceito histórico e político que nasce junto com o conceito de soberania.

No que refere aos motivos de criação do Estado, o autor apresenta as possibilidades que chama de "formação originária". Aquela que surge de uma organização social que não foi ligada a outro Estado e a "formação derivada" que por sua vez seria aquela em que o Estado se origina de uma organização já existente anteriormente.

\footnotetext{
Ao se estudarem as causas do aparecimento dos Estados é preciso, antes de tudo, lembrar que há duas questões diferentes a serem tratadas: de um lado, existe o problema da formação originária dos Estados, partindo de agrupamentos humanos ainda não integrados em qualquer Estado; diferente dessa é a questão da formação de novos Estados a partir de outros preexistentes, podendo-se designar esta forma como derivada (DALLARI, 1998, p. 23).
}

Tomamos por base as posições de criação do Estado a partir das ideias de formação originária fazendo a reflexão em consonância com o pensamento dos autores como Hegel, Marx/Engels e Gramsci, buscando situar um marco de referência sobre a concepção de Estado para compreendermos a formulação da política de formação de gestores estudada nessa pesquisa.

\subsection{Estado a partir de Marx e Gramsci}

Considerando o referencial de Dallari (1998), vemos que a origem do Estado por motivos econômicos tem Marx e Engels como importantes representantes dessa percepção, como ressalta o autor: "entre as teorias que sustentam a origem do Estado por motivos econômicos, a de maior repercussão prática foi e continua sendo a de MARX e ENGELS" (p.24).

O autor cita o próprio Engels em sua obra "A Origem da Família, da Propriedade Privada e do Estado" para mostrar as concepções de formação do Estado: 
Além de negar que o Estado tenha nascido com a sociedade, ENGELS afirma que ele "é antes um produto da sociedade, quando ela chega a determinado grau de desenvolvimento". [...] Faltava apenas uma coisa: uma instituição que não só assegurasse as novas riquezas individuais contra as tradições comunistas da constituição gentílica; que não só consagrasse a propriedade privada, antes tão pouco estimada, e fizesse dessa consagração santificadora o objetivo mais elevado da comunidade humana, mas também imprimisse o selo geral do reconhecimento da sociedade às novas formas de aquisição da propriedade, que se desenvolviam umas sobre as outras - a acumulação, portanto, cada vez mais acelerada das riquezas: uma instituição que, em uma palavra, não só perpetuasse a nascente divisão da sociedade em classes, mas também o direito da classe possuidora explorar a não possuidora e o domínio da primeira sobre a segunda. E essa instituição nasceu. Inventou-se o Estado. (DALLARI, 1998, p.23-24).

No pensamento marxista de Estado existem posições de diferentes estudiosos que as consideram concepções muito reduzidas às preocupações sobre a separação entre poder e a possível transição do Estado, por exemplo, como é sinalizado por Bobbio (2000) e por outros que afirmam a não existência de uma teoria política de Estado em Marx.

No entanto, vale considerar que Marx tratou mais especificamente desse assunto nas obras de sua juventude, momento em que ele começa a reinterpretar as obras de Hegel, e passa a tecer críticas àquilo que ele acreditava enquanto militante e sujeito mais próximo das classes operárias. Outros estudiosos, após a morte de Marx, como o próprio Engels, Gramsci e outros, desenvolveram estudos mais completos a partir da não completude da obra "O Capital” de Marx, mais especificamente sobre uma teoria de Estado.

Karl Marx foi um teórico que não teve a intenção de esclarecer conceitos acerca da origem do Estado Moderno e da sociedade civil, mas preocupou-se, assim como Hegel, em compreender a relação entre essas instituições no contexto da ordem burguesa. Seus estudos da juventude partem das interpretações sobre a leitura da obra de Hegel "Princípios da Filosofia e do Direito", e em 1844 apresenta suas primeiras reflexões no texto "Contribuição Crítica da Filosofia do Direito de Hegel. Introdução”.

Estudiosos marxistas, como Liguori (2006), destacam que à medida que ocorre o amadurecimento intelectual de Marx, em muitas de suas obras e produções e, sobretudo, com sua parceria a Engels, há uma compreensão mais elaborada desses conceitos. Assim, a concepção de Estado vai se evidenciando nas obras: "O Manifesto do Partido Comunista" (1848), “As lutas de classe na França” (1850), “O 18 Brumário de Luís Bonaparte” (1852) e "A guerra civil na França” (1871).

Barros (2008) também ressalta a obra de Engels, "A origem da família, da propriedade privada e do Estado (1995)", em que o autor faz uma contribuição sobre o 
Estado, que se refere mais a apontamentos críticos do Estado burguês, tendo em vista que ele não tinha a pretensão de construir uma teoria do Estado.

[...] há na obra de Engels, [...] uma elaboração teórica sobre o nascimento do Estado, assim como pode-se encontrar em toda a obra de Marx, como também nos textos que redigiu em parceria com Engels, uma crítica ao Estado burguês. No entanto, uma teoria sistemática do Estado socialista não existe, e seria, na verdade, contraditório se existisse quando sabemos que as conclusões de Marx o conduzem a acreditar na extinção do Estado. (BARROS, 2008, p.5).

Assim, uma importante conclusão de Marx aparece após a leitura e compreensão da obra hegeliana, considerando como ponto de partida as críticas feitas por Feurbach a Hegel a respeito da religião quando aquele afirma que é o homem que cria a religião e não a religião que cria o homem, contrariando o pensamento de Hegel. Da mesma forma, Marx vai mostrar que é a sociedade que expressa o Estado e não o contrário como alegou Hegel.

Reza o fundamento da crítica ímpia: é o homem que faz a religião, não a religião que faz o homem [...]. O homem é de fato, o mundo do homem, o Estado, a sociedade. Esse Estado, essa sociedade produzem a religião, uma consciência de mundo equivocada, por constituírem um mundo equivocado [...] A crítica do céu transforma-se assim em crítica da terra, a crítica da religião em crítica do direito, a crítica da teologia em crítica da política. (MARX, 2010, p.30-32). (grifos do autor).

Contrapondo a visão absoluta de Estado defendida por Hegel, Marx propõe a necessidade de haver o rompimento desse idealismo hegeliano, dessa inversão feita de que o sujeito que é o Estado e o predicado que é a sociedade civil. Então o Estado não pode ser pensado como instância máxima, acima da família, da sociedade civil, de tudo, pois devem ser levadas em consideração as realidades históricas e concretas que o precede.

Nessa compreensão, é a partir da sociedade civil que se pode compreender o Estado. Aquela é composta por homens que desenvolvem uma relação com o Estado e, portanto, tratam-se dos homens realmente como eles são, "como agem, como produzem materialmente, como atuam”. (MARX, ENGELS, 2009, p.30).

A sociedade civil compreende todo o intercâmbio material dos indivíduos numa determinada etapa do desenvolvimento das forças produtivas. Compreende toda a vida comercial e industrial de uma etapa, e nessa medida transcende o Estado e a nação, embora, por outro lado, tenha de se fazer valer em relação ao exterior como nacionalidade e de se articular como Estado em relação ao interior. (MARX, ENGELS, 2009, p.110). 
Na obra "Ideologia Alemã", Marx e Engels teorizam que a base da estrutura social está nas condições materiais e nas relações de produção. Consideram que, para o homem existir, primeiro ele precisa ter condições de viver. A vida é entendida também como a capacidade de produção de ideias, consciência, valores, sentimentos. Isso é o pressuposto primeiro da existência humana e de toda sua história, a qual é feita em convívio com outros indivíduos e com o meio social que ele vive.

Assim, para o homem ter condições de viver ele precisa antes de tudo ter condições de "comer, beber, habitar, vestir-se e algumas coisas mais". (MARX e ENGELS, 2009, p. 40). Trata-se de considerar o processo de vida real dos homens.

Em completa oposição à filosofia alemã, a qual desce do céu para a terra, aqui sobe-se da terra ao céu. Isto é, não se parte daquilo que os homens dizem, imaginam ou se representam, e também não dos homens narrados, pensados, imaginados, representados, para daí se chegar aos homens em carne e osso; parte dos homens realmente ativos e, com base no seu processo real de vida. (p.41).

O processo real de vida dos homens tem no trabalho seu importante instrumento de garantia para satisfazer suas necessidades vitais. Ocorre que, com a divisão social do trabalho e da propriedade privada, resulta a contradição entre os interesses individuais e comunitários, levando, assim, a criação do Estado no contexto dessas relações de produção, ao contrário do que pensava Hegel. "E é precisamente por essa contradição do interesse particular e do interesse comunitário que o interesse comunitário assume uma organização autônoma, como Estado, separado dos interesses reais dos indivíduos". (MARX, ENGELS, 2009, p.47). (grifos dos autores).

O que serve de mediação para a relação entre o Estado, a família e a sociedade civil, são também os elementos que constituem o Estado, portanto não são secundários a ele.

A razão do Estado nada tem a ver, portanto, com a divisão da matéria do
Estado em família e sociedade civil. O Estado provém delas de um modo
inconsciente e arbitrário. Família e sociedade civil aparecem como o escuro
fundo natural donde se acende a luz do Estado. Sob a matéria do estado estão
as funções do estado, bem entendido, família e sociedade civil, na medida
em que elas formam partes do Estado, em que participam do estado como
tal. [...] A família e a sociedade civil são apreendidas como esferas
conceituais do Estado. (MARX, 2005, p. 29).

Marx e Engels, à proporção que desenvolvem estudos sobre a sociedade capitalista da época em que viveram, demonstram que, à medida que as formas de produção e de intercâmbio, que ocorriam entre as diferentes nações e dessas entre si internamente, iam sendo 
desenvolvidas, novas forças produtivas também iam surgindo e, com isso, ampliando a divisão do trabalho, culminando na formação da propriedade privada, a partir de um movimento que é histórico, dinâmico e que culmina por sua vez, na instituição "Estado".

As diferentes fases de desenvolvimento da divisão do trabalho são outras tantas formas diferentes de propriedade; ou seja, cada uma das fases da divisão do trabalho determina também as relações dos indivíduos entre si no que diz respeito ao material, ao instrumento e ao produto do trabalho. [...]. (MARX e ENGELS, 2009, p.26).

Importante perceber como Marx, no seu tempo histórico e real, já conseguia demonstrar as desigualdades de classes existentes, mesmo nas relações desenvolvidas nas sociedades escravista, feudal e, posteriormente, na capitalista.

Cada uma dessas etapas de desenvolvimento da burguesia foi acompanhada por um progresso político correspondente. Segmento social oprimido sob a dominação dos senhores feudais; organizado em associação armada autogerida na comuna; aqui república urbana independente, ali terceiro estado sujeito aos impostos na grande monarquia; ou, mais tarde, no período manufatureiro, contrapeso da nobreza na monarquia feudal ou absoluta; no geral, principal fundamento da grande monarquia - com o estabelecimento da grande indústria e do mercado mundial a burguesia conquistou, finalmente, o domínio público exclusivo no Estado representativo moderno. (MARX, ENGELS, 2008, p.11-12)

Considerando o contexto histórico, político e econômico vivido pelos teóricos, o pensamento a respeito da política e do Estado parte do entendimento de que ele representava a expressão direta e imediata do domínio de classe exercido pela coerção da classe dominadora, como se evidencia no trecho da obra "O Manifesto do Partido Comunista", em que reconhece o Estado como um comitê administrativo burguês. "O poder político do Estado moderno não passa de um comitê que administra os negócios comuns da classe burguesa como um todo". (MARX, ENGELS, 2008, p.12).

Assim, para Marx e Engels, o Estado se fortalece com o surgimento das desigualdades de classes, ou seja, com a propriedade privada e a divisão social do trabalho e se configura como um instrumento de domínio dessas classes, "ele nada mais é do que a forma de organização que os burgueses se dão, tanto externa quanto internamente, para garantia mútua da sua propriedade e dos seus interesses”. (MARX, ENGELS, 2009, p. 112).

Barros (2008) sintetiza a concepção de Estado em Marx apontando que: 
O Estado, desse modo, é a forma pela qual os indivíduos de uma classe dominante fazem valer seus interesses comuns e na qual se resume toda a sociedade civil de uma época. A divisão do trabalho, no âmbito da referida sociedade civil, produz a desigualdade e, por conseguinte, a instauração do Estado. Porém, essa divisão do trabalho não pode ser abolida - e aqui Marx e Engels fazem uma ironia ao modelo de Hegel - extirpando do cérebro essa representação geral, mas, apenas, se os indivíduos subjugarem novamente essas forças materiais e puserem um fim à divisão do trabalho. Destarte, para que os proletários possam se tornar livres, devem se contrapor ao Estado, conjurando sua destruição a fim de realizarem sua personalidade. (p.13).

Vemos que o Estado representa o produto das relações e contradições estabelecidas na sociedade e não um poder que se impõem de dentro para fora, pois como defende Marx e Engels, é o modo de vida material que determina o processo social. Embora nas formas mais primitivas, a presença do Estado seja claramente destacada pelas relações de dominação, no Estado moderno, com o modo de produção capitalista sendo desenvolvido e cada vez mais aperfeiçoado, nem sempre esse caráter fica evidenciado, pois ele se sustenta por ideologias que mascaram seu real poder, escondendo suas contradições.

Nessa visão marxiana, a sociedade civil é o campo em que ocorrem as relações econômicas sendo, portanto, campo dos conflitos de classe e o Estado é o representante dos interesses das classes hegemonicamente dominantes. Dessa forma, Marx e Engels defendem a necessidade do desenvolvimento de uma emancipação coletiva no interior da sociedade e não apenas no âmbito do interesse da democracia burguesa. Nesse caso, a sociedade civil deveria ser uma instituição politizada, ou seja, uma instituição que podia moldar o Estado e não o contrário, como postulava Hegel.

A sociedade civil como uma instituição que se apresentava como um campo de conflitos de classe, como também coloca Liguori (2006), faz parte do momento estrutural que “para Marx, é o ‘teatro da história' é a estrutura, a economia” (p.3).

Martins (2005) pontua o Estado em Marx concebido como uma "estrutura coercitiva de classes que se projetava sobre a sociedade para submetê-la por intermédio da sociedade política" (p.126). Trata-se de uma concepção coerente, pois os Estados na época de Marx e Engels se comportavam como estruturas repressoras. Nesse sentido, o autor coloca que a estratégia de luta pela transformação social dos autores marxianos também se apresentava coerentes com o momento vivido por eles, que seria pela via da revolução comunista.

Essa questão fica evidenciada, entre outras passagens, na obra “A Ideologia Alemã”:

é necessária uma transformação massiva dos homens, que só pode processar num movimento prático, numa revolução; que, portanto, a revolução não é só necessária porque a classe dominante de nenhum outro modo pode ser 
derrubada, mas também porque a classe que a derruba só numa revolução consegue sacudir dos ombros toda a velha porcaria e tornar-se capaz de uma nova fundação da sociedade. (MARX, ENGELS, 2009, p.57). (grifos do autor).

$\mathrm{Na}$ visão marxiana, o Estado é pensado dentro do seu contexto que é histórico e material. Assim, não é o Estado que dá forma à sociedade, mas sim é essa que o forma e o institui, considerando os modos e os processos de produção e a consequente formação econômica e social. Por sua vez, esse pensamento é superado por outros autores marxianos.

Bacellar (2011), por sua vez, aponta que o legado de Marx sobre a concepção de Estado não pode ser pensado apenas sob a interpretação do Estado burguês como sendo "um corpo burocrático-militar", pois o autor sinaliza as análises de Marx sobre a Comuna de Paris as quais indicaram importantes elementos para se pensar a questão do Estado em seu estágio de transição:

[...] conjugação em um órgão de trabalho das funções legislativas e executivas; preservação do sufrágio universal, combinado com a revogabilidade dos mandatos dos representantes comunais, assim como dos demais servidores públicos, inclusive magistrados e juízes; nivelamento da remuneração dos servidores públicos aos salários dos operários; instituição do ensino gratuito e laico; desoficialização e expropriação de todas as igrejas; despojamento das atribuições políticas da burocracia e da polícia, conservando apenas as funções técnicas; e, extinção das forças coercitivas, como o exército permanente. (p. 6-7).

Em continuidade aos estudos de Marx, Engels avança sobre essas percepções a partir de críticas e autocríticas estabelecidas sobre os acontecimentos após a Revolução de 1848, em relação ao modo de luta que era proposto com base em uma transformação social por meio de uma estratégia revolucionária. Outros acontecimentos também como o aparecimento de uma nova classe burguesa do novo período histórico e político que se configurava, como argumenta Bacellar (2011).

Esse autor também pontua que Engels se apresentou como um dos primeiros autores a mostrar mudanças sobre a concepção de revolução, destacando em seguida o autor marxiano Gramsci, o qual apresentou uma renovação e avanço desses conceitos, mas ressaltando que essas mudanças de visões ocorreram no sentido de acrescentar maior solidez e não no sentido de abominá-las.

É importante mencionar que Antônio Gramsci viveu sob condições sociais, políticas e, sobretudo, econômicas diferentes das vividas por Marx e Engels. Martins (2005) sinaliza esse contexto da vida de Gramsci pontuando, por exemplo, que o capitalismo de sua época era 
característico do "Americanismo e Fordismo", momento em que se mudam tanto os modos de produção material quanto o próprio modo de vida dos indivíduos e, desse modo, o Estado é um elemento constitutivo desse contexto. Sobre esse modelo trataremos com mais detalhes no próximo capítulo.

Nela, muda-se a produção, o trabalho, a ética, os aspectos psíquicos
humanos e toda a superestrutura jurídico-política da sociedade. [...] o Estado
é para Gramsci um dos elementos constitutivos dessa realidade modificada e
cambiante, e em sua lógica de funcionamento vai refletir as mudanças da
estrutura e da superestrutura social. (MARTINS, 2005, p. 125).

Em Gramsci, a sociedade civil e o Estado têm diferenças de ordem metodológica, mas são diferenças que os unem de forma orgânica como pontua Liguori (2006), portanto não são diferenças de natureza orgânica que os separa como muitos autores tentaram mostrar, como Bobbio, por exemplo.

Liguori (2006) argumenta que a posição gramsciana é a de reafirmar a "unidade real" pela qual compõe a totalidade do Estado entendido na sua dimensão ampliada, no qual estrutura, superestrutura, economia, cultura e política são esferas que o constituem, sendo, ao mesmo tempo, autônomas e unidas, conforme a concepção original marxiana de totalidade e de unidade dialética e, nesse sentido, amplia a concepção de Marx. "Enquanto Marx pensa a relação dialética da sociedade e do Estado a partir da sociedade, Gramsci pensa essa relação dialética da sociedade e do Estado a partir do Estado 'corrigindo' e 'reequilibrando' um progressivo desequilíbrio interpretativo". (LIGUORI, 2006, p.6).

No mesmo sentido, a sociedade civil em Gramsci é parte constituinte do Estado e representa o conjunto de organizações formadas por grupos que se organizam em torno de interesses comuns. Mendonça (2012) auxilia na compreensão desse conceito de sociedade civil destacando que ele se refere "à organização e à produção de vontades coletivamente organizadas, implicando em visões de mundo, em consciências sociais e em formas de ser adequadas - ou opostas - aos interesses burgueses". (p.3).

A sociedade civil busca obter aparelhos privados de hegemonia por meio da organização politizada. Ela representa um conjunto de aparelhos hegemônicos, de instâncias diversas que são representadas tanto por grupos dominantes quanto por grupos dominados. Por sua vez, esses grupos precisam garantir que seus membros façam sua adesão de forma voluntária e não pela força e, por isso, uma grande estratégia é o convencimento que pode ser feito pelo intelectual orgânico, importante personagem para garantir essa adesão e organização dos grupos. 
A sociedade política representa a instituição que detém o poder de repressão, da força e correção, ou seja, o Estado em sentido restrito. Mendonça (2014) argumenta que essa sociedade também é chamada de "Estado político" ou "Estado-governo": "os aparelhos governamentais incumbidos da administração, da organização dos grupos em confronto, bem como do exercício da coerção sobre aqueles que não consentem, sendo por ele também denominado de 'Estado político' ou Estado-governo"”. (p.35).

Mendonça (2012) pontua que há um dado que os unifica:

[...] todos são formas organizativas que se referem às formas de produção econômica (infraestrutura) e política (Estado), ainda que sua atuação seja basicamente cultural, ou seja, a busca de organização de vontades coletivas, calcadas em valores e eticidade próprios, em prol da afirmação de projetos de mudança ou conservação - que se tornem hegemônicos. Daí a importância dos intelectuais, responsáveis tanto pela organização das vontades coletivas, quanto pela estruturação do convencimento para o exercício da hegemonia ou contra-hegemonia. (p.3).

O Estado é o espaço onde a classe dominante exerce e mantém seu poder, visão original de Marx, mas é também o espaço em que ocorre o convencimento, o jogo de consentimento, por meio de um aparato hegemônico, a sociedade civil. "Além do aparelho de governo, também o aparelho 'privado' de hegemonia da sociedade civil”. (GRAMSCI, 2016, p. 258).

Trata-se de uma concepção ampliada de Estado que é pensada a partir das relações entre a sociedade civil e a sociedade política, sendo "Estado = sociedade política + sociedade civil, isto é, hegemonia couraçada de coerção". (GRAMSCI, 2016, p, 248). Há uma integração que é dialética nessa relação social entre ambas, que embora se apresentem com características distintas, são também inseparáveis, como coloca Semearo (1999).

Para evitar os perigos do "economicismo" e do "estatismo", Gramsci defende uma relação dialética de "identidade-distinção entre sociedade civil e sociedade política", duas esferas distintas e relativamente autônomas, mas inseparáveis na prática. De fato, a primeira - composta de organismos privados e voluntários - indica a "direção", enquanto a segunda estruturada sobre aparelhos públicos - caracteriza-se mais pelo exercício do "domínio". O Estado moderno não pode mais ser entendido como um sistema burocrático-coercitivo. As suas dimensões não podem se limitar aos instrumentos exteriores de governo, mas abarcam também a multiplicidade dos organismos da sociedade civil onde se manifesta a livre iniciativa dos cidadãos, seus interesses, suas organizações, sua cultura e seus valores, onde, praticamente, se estabelecem as bases do consenso e da hegemonia. (SEMEARO, 1999, p.5). 
Essas relações se vinculam às condições de desenvolvimento das forças e produção e acumulação de acordo com cada sociedade, suas características históricas, assim como pelas possibilidades do estabelecimento de consensos pela hegemonia entre os grupos a partir de vontades e ações coletivas.

Coutinho (2009) pontua que a vontade coletiva em Gramsci está ligada ao pensamento de "reforma intelectual e moral", que por sua vez está relacionado à concepção de hegemonia. Já nas produções da maturidade gramsciana, Coutinho aponta que o autor consegue mostrar essa ideia como uma superação dialética. Assim, a vontade coletiva continua tendo um papel importante na construção da ordem social, mas "não mais como 'plasmadora' da realidade, mas sim como um momento decisivo que se articula com as determinações que provêm da realidade objetiva, particularmente das relações sociais de produção". (2009, p. 3).

Dessa forma, Gramsci propõe uma reforma intelectual e moral, a qual será possível na medida em que a classe subalterna e proletária alcançar a condição hegemônica. Assim, poderá ser possível resolver as contradições tanto em nível dos dominantes, quanto em nível dos dominados.

Por sua vez, a hegemonia em Gramsci é a busca pelo consenso de lideranças políticas, ideológicas e culturais de uma classe sobre outra classe e, nesse sentido, ela não é entendida apenas como coerção, mas como possibilidade de consenso a partir do convencimento de intelectuais $^{2}$ que assumem a liderança dos grupos na sociedade civil na perspectiva da “filosofia da práxis" que ocorre articulando a "reflexão do 'bom senso' a partir da prática cotidiana das massas e de sua experiência na luta política” (VIEIRA, 2009, p.68).

A esse respeito, Costa (2016) também argumenta:

\begin{abstract}
A hegemonia seria a capacidade de um grupo social unificar em torno de seu projeto político um bloco mais amplo não homogêneo, marcado por contradições de classe. O grupo ou classe que lidera este bloco é hegemônico porque consegue ir além de seus interesses econômicos imediatos, para manter articuladas forças heterogêneas, numa ação essencialmente política, que impeça a irrupção dos contrastes existentes entre elas. (p. 3).
\end{abstract}

Por sua vez, esses grupos são tanto mais hegemônicos quanto são organizados, reafirmando-se a importância da figura do intelectual, o intelectual orgânico, aquele que consegue encaminhar as massas à filosofia da práxis. Trata-se de um intelectual que consegue unir teoria e prática, elevar a consciência dispersa das massas a um nível mais coerente e

\footnotetext{
${ }^{2} \mathrm{O}$ Intelectual na perspectiva gramsciana é entendido como o indivíduo que atua como preposto do grupo dominante para o exercício das funções subalternas da hegemonia social e do governo político. Trata-se de um conceito que supera a simples ideia de distinção entre manual e instrumental, aproximando-se da realidade concreta. (VIEIRA, 2009, p.67).
} 
homogêneo da classe a que pertence, difundindo a consciência de mundo revolucionário. (VIEIRA, 2009).

Mendonça (2014) também ressalta que "o pleno desenvolvimento de uma classe - ou fração - depende de sua capacidade de gerar seu próprio quadro de intelectuais, aptos a lhe conferirem homogeneidade e mesmo consciência de sua função, seja no âmbito econômico, político ou ideológico”. (p.35).

Nesse mesmo sentido, conforme proposto por Vieira (2009), para que a classe subalterna compreenda a realidade social e produza ações de superação e chegue ela mesma à condição hegemônica, é necessário que ela se conscientize da "incoerência do senso comum vigente entre eles e dos interesses como classe" e associado a isso, que seja desencadeado um “processo 'catártico' entre as classes subalternas pelo qual elas possam assumir-se como grupo social, com condições de libertar-se das subserviências a que estão submetidas”. (p.63).

Assim, o Estado ampliado seria melhor evidenciado nas chamadas "sociedades ocidentais" e o Estado restrito mais característico das "sociedades orientais", pois nessas a sociedade civil não é desenvolvida nem autônoma, é, portanto, primitiva e o Estado é considerado como representante maior. Já as sociedades ocidentais são representadas pelas regiões em que há equilíbrio entre a sociedade política e sociedade civil e onde o Estado não é o representante maior.

No Oriente, o Estado era tudo, a sociedade civil era primitiva e gelatinosa; no Ocidente, havia entre o Estado e a sociedade civil uma justa relação e, ao oscilar o Estado, podia-se imediatamente reconhecer uma robusta estrutura da sociedade civil. O Estado era apenas uma trincheira avançada, por trás da qual se situava uma robusta cadeia de fortalezas e casamatas; em medida diversa de Estado para Estado, é claro, mas exatamente isso exigia um acurado reconhecimento de caráter nacional. (GRAMSCI, 2016, p.266).

No entanto, isso não quer dizer que na sociedade civil não haja conflitos, pois como é formado por grupos distintos (igrejas, associações, escolas, sindicatos, partidos...), ela também representa uma arena de lutas de classes em que são muito presentes as disputas pela busca de consenso.

Em algumas passagens do Caderno do Cárcere, volume 3, essas questões se apresentam: "A divisão dos poderes e toda a discussão havida para sua efetivação e a dogmática jurídica derivada de seu advento constituem o resultado da luta entre sociedade civil e a sociedade política de um determinado período histórico, com certo equilíbrio instável entre as classes". (GRAMSCI, 2016, p.238). 
Mendonça (2014) ressalta então a questão do consenso e da coerção:

[...] para o pensador italiano, que tanto inovou o campo do marxismo com sua singular definição de Estado ampliado - ou Integral -, a marca peculiar ao Estado capitalista, desde sua época, reside no fato dele guardar, simultaneamente, um espaço de consenso e não apenas de violência, sendo o consenso - consentimento - obtido, segundo ele, através da ação dos aparelhos de hegemonia da sociedade civil, assim como através do próprio Estado restrito, que promove e generaliza o projeto da fração de classe hegemônica em certo contexto historicamente dado. Logo, política e Estado são inseparáveis da cultura e, mesmo instituições da sociedade política tipicamente relacionadas com a coerção - como o Exército, por exemplo respondem pela difusão de uma dada cultura. (p. 37).

Nesse sentido, alcançar a transformação social e do Estado significava alcançar a multiplicação dos aparelhos de hegemonia da sociedade civil na medida em que ela atuasse inserindo e mantendo seus intelectuais na sociedade política de modo a manter a disputa de um projeto hegemônico em busca da hegemonia. (MENDONÇA, 2014).

Gramsci, como um autor marxiano, não desconsiderou as análises e apontamentos feitos sobre o Estado por Marx e Engels, de que ele era uma estrutura coercitiva de classe, e que para superá-la, seria necessária, como estratégia de luta, a revolução comunista, mas superou e ampliou essas concepções chegando a uma nova estratégia revolucionária.

Martins (2005) pontua que a essa concepção marxiana de Gramsci vai ser denominada de "guerra de movimento" e que, por sua vez, refere-se à "estratégia que privilegia como método de ação libertadora, como método revolucionário a ser utilizado pelo proletário, o assalto direto ao poder, que tem na força o seu elemento primordial para a tomada do poder". (p.127).

Considerando a nova configuração econômica e social dos séculos XIX e XX, Gramsci postulou novas estratégias. Por meio de críticas e autocríticas, Martins (2005) argumenta que Gramsci "promove uma reavaliação da situação estrutural e superestrutural, tendo como perspectiva compreender a situação concreta para promover ações que possam alterá-la qualitativamente em benefício das classes subalternas.” (p. 129).

[...] a sociedade civil transformou-se em uma estrutura complexa e mais resistente às crises, e as superestruturas passaram a funcionar como o sistema de trincheiras utilizado nas guerras modernas. Nesse caso, nem as tropas atacantes, por causa da crise, organizam-se rapidamente no tempo e no espaço, nem os atacados sentem-se desmoralizados o suficiente para abandonarem suas defesas, nem perdem de imediato a confiança em sua força, já que o elemento surpresa, do tempo acelerado, não aparece de acordo com o que imaginavam os estrategistas da guerra de movimento. (COSTA, 2016, p.3). 
Das postulações gramscianas, surge a visão da "guerra de posição" como sendo uma nova estratégia para a passagem ao socialismo em que seria a superação da realidade capitalista nas chamadas sociedades ocidentais, como nos referimos anteriormente, por serem consideradas as sociedades capitalistas mais desenvolvidas. Essa guerra exige uma participação organizada da hegemonia como coloca Gramsci em Cadernos do Cárcere, volume 3 .

A guerra de posição exige enormes sacrifícios de massas imensas de população; por isto, é necessária uma concentração inaudita da hegemonia e, portanto, uma forma de governo mais "intervencionista", que mais abertamente tome a ofensiva contra os opositores e organize permanentemente a "impossibilidade" de desagregação interna: controles de todo o tipo, políticos, administrativos, etc., reforço das "posições" hegemônicas do grupo dominante, etc. (GRAMSCI, 2016, p. 259).

Esse tipo de guerra caracteriza-se num processo longo em que o partido revolucionário, a sociedade civil, busca exercer a hegemonia entre os setores sociais, dentre os quais os trabalhadores e, em especial, a classe operária, seriam os maiores interessados.

$\mathrm{Na}$ compreensão de Martins (2005), essa nova estratégia de passagem para o socialismo supera a compreensão da "guerra de movimento" indicando, portanto que ela ocorrerá pela "guerra de posição" e que, portanto, resulta dos embates tanto entre as relações sociais de produção material e como também das relações político-ideológicas e culturais.

A transformação radical da sociedade e a substituição de um sistema socioeconômico por outro (o capitalismo pelo socialismo) devem ser entendidas, portanto, como processos resultantes de intensa luta política e ideológica na qual se busca produzir, por meio dos embates sociais e da ampla discussão em torno do projeto contra-hegemônico, uma nova visão de mundo a ser abraçada pela maioria da população, um novo consenso, um novo senso comum. Trata-se de elaborar uma nova concepção de mundo através de uma análise crítica e consciente da realidade presente e da intervenção ativa na história, para que se enfrente a concepção de mundo dominante, imposta pelos grupos sociais dominantes. (COSTA, 2016, p. 4).

Entre os objetivos de uma luta revolucionária, é importante a presença de um novo tipo de ser humano para as novas formas de trabalho e de produção, "um homem (individual e coletivo) que tenha uma nova postura ante o mundo que o cerca”. (COSTA, 2016, p. 136). 


\subsection{Noções sobre Estado de Bem-Estar Social e de Estado Neoliberal}

No século XX, a partir de 1930, entra em vigor um novo modelo econômico conhecido por Estado de Bem-Estar Social. Após a Primeira Guerra Mundial (1918), e a Crise Econômica de 1929, o capital entra em crise e um novo modelo é demandando para manter o capital vivo. Assim de forma contraditória, mas representando-se uma alternativa, o novo modelo de Estado Interventor tem como características a promoção e a defesa aos direitos sociais.

O Estado intervencionista, denominado de Estado de Bem-Estar Social, EstadoProvidência ou Welfare State, representa um sistema político e econômico com base na livre empresa, mas com a presença do Estado nos assuntos sociais. Esse tipo de Estado surge como uma forma de reverter problemas advindos do liberalismo e do absolutismo, considerando o processo de industrialização dos países europeus e a necessidade de criação de políticas sociais, e como destaca Draibe (1993), representando uma forma de garantir direitos e a proteção dos serviços públicos, os quais deveriam ser regulamentados pelo Estado para garantia de bem-estar a todos.

Groppo (2005) lembra que esse é um dos tipos históricos do Estado Moderno e ele foi um Estado Interventor considerando que, "parecia conformar um todo coerente e duradouro, cujos direitos sociais propalados aparentemente tinham eterna vigência garantida, incluindo uma educação pública gratuita, de qualidade e inclusiva”, (p.2), no entanto, não foi isso que ocorreu no seu processo de desenvolvimento.

Interventor e Provedor, na medida em que representa um modelo de Estado adotado na Europa Ocidental no qual visava criar políticas com a intenção de garantir qualidade de vida para todos os cidadãos numa perspectiva mais assistencialista evitando, assim, problemas de ordem social.

Ao discutir as origens e decadências do Estado de Bem-Estar Social, Groppo (2005) o faz a partir da integração desse tipo de Estado com o capitalismo, tendo em vista que após as guerras mundiais, esse modelo se apresenta como um instrumento de auxílio aos problemas sociais e econômicos em âmbito mais funcionalista como ressalta o autor, já que, pelo menos por um período, houve crescimento econômico mundial.

[...] a busca de um modelo que suavizasse os conflitos de classe, a busca de uma rotina que aliasse crescimento econômico com distribuição de renda (impedindo a temida "Revolução"), a construção de instituições que resolveriam - no âmbito estatal - as querelas advindas dos diferentes 
interesses de classe e de frações de classe. A aceleração da internacionalização e, enfim, da globalização da economia, num primeiro momento constrói a possibilidade do Estado de Bem-Estar - durante o período de enorme crescimento econômico no Pós-2 ${ }^{\mathrm{a}}$ Guerra Mundial. (GROPPO, 2005, p.2).

Nesse modelo de Estado, predominou a organização da administração produtiva conhecida como Fordismo que, segundo Antunes (2003), baseava-se na produção em massa de mercadorias, sendo que a atividade de trabalho se reduzia a atividades mecânicas e repetitivas realizadas por operários semiqualificados. Considerando a esfera econômica, Silva Junior e Sguissardi (2001) argumentam que se trata de um modelo que tem a "base produtiva com tecnologia rígida, produtos homogêneos e produção em larga escala”, (p.104), e lembram, ainda, que ao se tratar de produção em massa, há também grande apelo para o consumo em massa.

Também é entendido como Estado Regulador, como apontam esses autores, pois, na esfera política e econômica, o Estado de Bem-Estar Social, precisava manter um compromisso com as classes criando políticas de distribuição de renda e para haver equilíbrio nesse modelo, essas políticas e legislações sociais precisavam ser regulados por meio de impostos e fundos públicos, geridos pelo Estado, o que representava para os autores um fetichismo do Estado capitalista.

O Estado de Bem-Estar Social, portanto, participa da reprodução do capital e da força de trabalho, ocupando, dessa maneira, um lugar central na dinâmica do Fordismo. Na medida em que participa da reprodução do capital e do trabalho, promovendo o compromisso, o Estado de Bem Estar Social desenvolve, ao mesmo tempo, uma intensa politização das relações entre capital e trabalho no interior do próprio Estado - oferecendo, desta forma, um certo grau de transparência do fetichismo do Estado Capitalista, que se apresenta como representante de toda nação, quando, ainda que com um certo grau de autonomia, representa e unifica os vários setores sociais ligados ao capital. (SILVA JÚNIOR, SGUISSARDI, 2001, p.105).

A gestão do fundo público pelo Estado tinha que levar em consideração as negociações políticas internas entre representantes do capital e do trabalho, o que segundo Silva Júnior e Sguissardi (2001), mostra como as instituições políticas e sociais tinham presença e como eram complexas as relações entre Estado e Sociedade, considerando a organização interna do fordismo que era rígida.

Antunes (2003) destaca que esse sistema de compromisso e regulação no Estado de Bem-Estar Social ficava limitado a uma parcela de países capitalistas avançados e, portanto, na verdade se oferecia uma ilusão de que "o sistema de metabolismo social do capital pudesse 
ser efetivo, duradouro e definitivamente controlado, regulado e fundado num compromisso entre capital e trabalho mediado pelo Estado" (p.38). (grifos do autor). Enquanto aos países subdesenvolvidos, que eram excluídos dos compromissos, restava a exploração do trabalho.

Ao mesmo tempo em que o Estado precisava criar mecanismos de regulação para equilibrar o sistema de produção e consumo, garantir a elevação das taxas de lucros nas empresas, precisava gerir os organismos políticos e ações de operários que se organizavam em sindicatos em busca de que seus direitos sociais fossem garantidos, como aponta Antunes (2003), “O compromisso fordista deu origem progressivamente à subordinação dos organismos institucionalizados, sindicatos e políticos, [...] convertendo esses organismos em verdadeiros cogestores do processo global de reprodução do capital”. (p.39).

Como estratégia para resolução desses e outros dilemas, Antunes (2003) ressalta que o Estado, na sua concepção de "Estado Providência", aproveita-se da situação de representante e gestor geral dos movimentos operários e organismos políticos, propagando-se sua concepção estadista por meio de um ideário de "poder coletivo, arbitral e de exterioridade frente ao capital e ao trabalho". (p.39), o que levou ainda mais a uma dependência ao Estado de Bem-Estar Social.

Esse processo significou, para segmentos importantes do proletariado europeu "um acréscimo da dependência tanto prática quanto ideológica, em relação ao Estado, sob a forma do famoso 'Estado-providência'. Dentro da moldura do fordismo, com efeito, esse Estado representa, para o proletariado, a garantia de 'seguridade social', com sua qualidade de gestor geral da relação salarial: é o Estado que fixa o estatuto mínimo dos assalariados (...); é ele que impulsiona a conclusão e garante o respeito das convenções coletivas; é ele que gera direta ou indiretamente o 'salário indireto"”. (ANTUNES, 2003, p.40).

Essas estratégias estatais são explicadas, como destaca Groppo (2005), por um dos maiores representantes do Estado de Bem-Estar Social que é Keynes, segundo o qual, a partir de suas preocupações com relação aos efeitos sociais negativos na economia, vai defender que a presença e interferência do Estado eram necessárias para garantir o emprego, o equilíbrio nas taxas de lucros, a criação de estatais e iniciativas de obras públicas garantindo a oferta de trabalho, além de que também poderia "impedir a convulsão do sistema pelas lutas de classe e pela revolução". (p.4).

No entanto, sinais de crises desse Estado começaram a surgir. A partir dos anos 1960 e 1970, como destaca Antunes (2003), a própria base de sustentação na produção por meio do profissional semiqualificado, capaz de cumprir ordens e fazer a mesma atividade por um 
longo período de tempo, já não se sustentava mais considerando as necessidades do capitalismo, as novas demandas de produção e as constantes ações e lutas de trabalhadores em busca de novas condições de trabalho. "Se o operário-massa foi a base social para a expansão do 'compromisso' social-democrático anterior, ele foi também seu principal elemento de transbordamento, ruptura e confrontação, da qual foram forte expressão os movimentos pelo controle social da produção". (p.41).

Outros sinais da crise ainda são destacados também por Antunes (2003), considerando que, após um longo período de acumulação de capitais, há uma queda da taxa de lucro causada pelo aumento do valor da mão de obra associado às constantes lutas sociais, levando a uma "redução dos níveis de produtividade do capital, acentuando a tendência decrescente da taxa de lucro"; Ocorre também um "esgotamento do padrão de acumulação taylorista/fordista de produção; Uma "hipertrofia da esfera financeira", que ganhava autonomia com relação aos capitais produtivos; Uma "maior concentração de capitais" a partir de fusões entre empresas; Destaca-se a também a crise fiscal e somado a isso, o processo crescente de privatizações”. (p.29-30).

Filgueiras (1997) ressalta que o fordismo não se caracterizou apenas como um modelo de organização do processo de trabalho, mas também como um "novo modo de vida", que vai além dos limites das fábricas e que levou à "construção de um novo homem”, o qual devia se adaptar às demandas exigidas pela dinâmica de produção e, nesse sentido, a crise do fordismo levou também à crise de certo "modo de vida". Acrescenta o autor que "A quebra de um pacto social, caracterizado pela busca do 'pleno emprego', por certa estabilidade no trabalho e por amplas garantias sociais. É justamente a destruição desse 'modo seguro de viver' [...] que dá origem à profunda instabilidade e insegurança específicas”. (p.904-905). Esses também são fatores muito relevantes e se somam aos motivos que levaram à crise do modelo de Estado vigente.

Como estratégias para saída da crise fordista têm-se o processo de reorganização do capital e do trabalho, a privatização do Estado e o neoliberalismo, como pontua Antunes (2003):

[...] iniciou-se um processo de reorganização do capital e do seu sistema ideológico e político de dominação, cujos contornos mais evidentes foram o advento do neoliberalismo, com a privatização do Estado, a desregulamentação dos direitos do trabalho e a desmontagem do setor produtivo estatal, da qual a era Thatcher-Reagan foi a expressão mais forte; a isso se seguiu também um intenso processo de reestruturação da produção e do trabalho, com vistas a dotar o capital do instrumental necessário para tentar repor patamares de expansão anteriores. (p.31). (grifos do autor). 
As propostas de reorganização do capital e do trabalho foram feitas a partir do processo de "acumulação flexível", ao lado de um modelo neoliberal de Estado. Esse modelo surge com ideais contrários ao do Estado de Bem-Estar Social, o qual representou a raiz dos problemas econômicos no período pós-guerra segundo Friedrich Hayek, um dos principais defensores desse modelo. Os escritos desse autor datam de 1944, mas inicialmente eles não foram levados a sério e somente depois com as consequências da crise impostas à sociedade capitalista, seu livro "Caminhos da Servidão" tornou-se "um verdadeiro manifesto político da direita", como destaca Silva Júnior. (2002, p. 31).

Nessa obra, “O Caminho da Servidão”, Hayek (2010) demonstra que os modelos de Estados anteriores não deram conta de resolver os problemas vivenciados pelas sociedades de cada época. Sobre o modelo liberal, por exemplo, ele afirma que o sucesso desse modelo foi a causa do seu próprio declínio.

O liberalismo veio a ser considerado uma filosofia "negativa" porque não podia oferecer a cada indivíduo mais do que uma participação no progresso comum - progresso cada vez mais considerado natural e inevitável e não mais encarado como decorrente da política de liberdade. Pode-se mesmo dizer que o próprio sucesso do liberalismo tornou-se a causa do seu declínio. Devido ao êxito já alcançado, o homem se foi mostrando cada vez menos disposto a tolerar os males ainda existentes, que a essa altura lhe pareciam insuportáveis e desnecessários. (HAYEK, 2010, p. 43-44).

O autor apresenta também suas concepções acerca de outros modelos de Estado, como o socialista, concepção que buscou superar o ideário liberalista, mas adverte que essa superação não foi positiva, e que ambos modelos deixaram a desejar. Faz críticas ao Estado de BemEstar Social e à sua concepção de construir "objetivos sociais" e "propósitos comuns" de organização da sociedade a partir de um "bem-comum”, entendendo que é difícil mensurar esse bem a todos de uma mesma forma, pois "O bem-estar e a felicidade de milhões não podem ser aferidos numa escala única de valores. O bem-estar de um povo, assim como a felicidade de um homem, depende de inúmeras coisas que lhe podem ser proporcionadas numa infinita variedade de combinações”. (HAYEK, 2010, p. 76).

Hayek defende então que o Estado Neoliberal se apresenta como uma solução contrária ao modelo de Estado de Bem-Estar social, sendo que o papel máximo e interventor desse passa a ser o de um Estado mínimo e não interventor. Defende a tese do individualismo e o respeito à liberdade individual, da qual faz parte a propriedade privada, por isso o mercado deve ser autônomo e representar a livre vontade dos indivíduos. 
O estado deve limitar-se a estabelecer normas aplicáveis a situações gerais deixando os indivíduos livres em tudo que depende das circunstâncias de tempo e lugar, porque só os indivíduos poderão conhecer plenamente as circunstâncias relativas a cada caso e a elas adaptar suas ações. Para que o indivíduo possa empregar com eficácia seus conhecimentos na elaboração de planos, deve estar em condições de prever as ações do estado que podem afetar esses planos [...] se o estado dirigisse as ações individuais visando a atingir objetivos específicos, teria de agir com base em todas as circunstâncias do momento, e, portanto, suas ações seriam imprevisíveis. Daí o conhecido fato de que, quanto mais o estado "planeja", mais difícil se torna para o indivíduo traçar seus próprios planos. (HAYEK, 2010, p.91-92).

Dessa forma, o neoliberalismo foi se constituindo como um terreno fértil, fortalecendo-se como a possibilidade de resolução de problemas. Na Inglaterra, um importante marco desse modelo ocorre a partir do governo de Margareth Thatcher (19791990) e espalha-se em outros países significando uma forma hegemônica de pensar e viver e como um guia teórico aos partidos políticos e aos governos. (FILGUEIRAS, 1997).

Se o modelo de Estado anterior entra em crise por conta de sua rigidez interna de sua organização, com o neoliberalismo e as propostas de flexibilização, busca-se reestruturar o modo de produção e de consumo a partir da "acumulação flexível”, termo utilizado por David Harvey para representar o confronto direto com a rigidez característica do modelo fordista, visando mostrar as possibilidades de flexibilidade dos processos de mercados de trabalho, de produtos e dos padrões de consumo.

Dentre as características da acumulação flexível, destacam-se o surgimento de novos setores de produção, novas maneiras de fornecimento dos serviços financeiros, novos mercados e a intensificação das taxas de inovação tecnológica e organizacional.

Esse modelo de acumulação representa, na visão de Harvey, uma saída à crise tendo em vista que ele envolve "rápidas mudanças dos padrões do desenvolvimento desigual, tanto entre setores como entre regiões geográficas, criando, por exemplo, um vasto movimento no emprego chamado de 'setor de serviços"”. (HARVEY, 2000, p.140).

No entanto, Antunes (2003) vai mostrar que esse sistema é contraditório e fica mais no plano do discurso, pois ao mesmo tempo em que propõem uma estrutura mais flexível por meio de "novas técnicas de gestão da força de trabalho", do trabalho em equipe, das "células de produção", dos "times de trabalho", dos grupos "semiautônomos", entre outras questões, ele continuou, assim como no modelo fordista, a exercer o controle sobre o processo de organização e exploração da força de trabalho. (p.52). 
Essa nova perspectiva de produção e organização do trabalho baseia-se na desregulamentação, na flexibilidade e na privatização das necessidades coletivas. Dessa forma, a ideologia do modelo anterior de consumo de bens duráveis muda para a ideologia do consumo individualizado e exacerbado como argumenta Antunes (2003),

\footnotetext{
Opondo-se ao contrapoder que emergia das lutas societais, o capital iniciou um processo de reorganização das suas formas de dominação societal, não só procurando reorganizar em termos capitalistas o processo produtivo, mas procurando gestar um projeto de recuperação da hegemonia nas mais diversas esferas da sociabilidade. Fez isso, por exemplo, no plano ideológico, por meio do culto ao subjetivismo e de um ideário fragmentador, que faz apologia ao individualismo exacerbado contra as formas de solidariedade e de atuação coletiva e social. (p.48). (grifo do autor).
}

No âmbito político, o neoliberalismo defende a democracia representativa, o Estado de Direito e os direitos individuais, no entanto não tem a intenção de dar abertura para movimentos sociais ou sindicais, tampouco se mostra preocupado com a execução de políticas sociais que "procurem diminuir as desigualdades entre indivíduos, pois isso acomoda seus beneficiários e arrefece a competição, motor maior da sociedade e da liberdade". (FILGUEIRAS, 1997. p.900).

Consumo, concorrência, individualismo, privatização, não intervenção seja do Estado, seja dos sindicados e movimentos sociais, mercantilização, reformas, flexibilização, entre outras, passam a ser as palavras dominantes no modelo de reestruturação do novo Estado. Importante ressaltar, como pontua Filgueiras (1997), que a não intervenção do Estado está ligada às questões sociais e não no que refere à intervenção econômica e política.

Nesse contexto de reestruturação econômica, surgem como mecanismos de ajuste neoliberal para auxiliar a elaboração e execução de projetos aos países ressurgentes da crise no pós-segunda guerra mundial, os Organismos Internacionais - OIs, como o Fundo Monetário Internacional (FMI), Banco Mundial, Banco Interamericano de Desenvolvimento (BIRD), Organização Mundial do Comércio (OMC), a Organização das Nações Unidas para a educação, a ciência e a cultura (UNESCO), a Comissão Econômica para a América Latina (CEPAL).

Silva Júnior e Sguissardi (2001) ressaltam que nessa nova ordem emergente, esses organismos internacionais despontam-se com um poder político e econômico para sedimentar as bases do modelo neoliberal a partir do regime de acumulação flexível. Inicialmente, foram criados com a intenção de prestar ajuda técnica e financeira, visando alcançar estabilidade econômica mundial e promover o crescimento, passando a interferir na "organização 
econômica e política dos Estados Nacionais, especialmente os chamados países em desenvolvimento". (p.109). Com o passar do tempo, suas funções foram sendo ressignificadas e passaram, inclusive, a ditar as diretrizes para as reformas nos Estados.

\subsection{Gênese, Evolução e Características do Estado Brasileiro}

Do ponto de vista da Teoria Geral do Estado, Teoria própria do Direito Constitucional, o Estado para ser considerado como tal, necessita de alguns requisitos elementares, como mencionamos anteriormente, a saber, "um território, uma população e um governo". Em geral, esse governo possui soberania que lhe permite o atributo de poder supremo dentro do seu território e de impor sua autoridade por meio de leis.

No Brasil, considerando seu surgimento, apesar de existir um povo nativo e um território, esse povo não era considerado como tal e o território foi motivo de muitas disputas. Da mesma forma, a representatividade do governo sempre foi marcada por constantes interesses econômicos por meio de lutas em busca do fortalecimento e da centralidade do poder.

Importante para essa compreensão também, é ter em mente a relação da origem dos Estados nacionais e a dinâmica do capital e o poder político, como destaca Roio (1999) "Sem a compreensão de que o Estado, tal como o mercado, é um elemento material constitutivo da dinâmica do capital, não conseguiremos escapar do plano da generalidade extrema da crise da reformulação do Estado brasileiro". (p.13).

Nesse contexto contraditório, o Brasil vem tentando, desde o seu episódio de Independência, consolidar suas bases democráticas, no entanto vive um dilema ao esbarrar em uma de suas características fundamentais, que é a não separação entre a esfera do público e do privado.

No período de colonização brasileira, Brasil Colônia, compreendido entre os anos de 1500 a 1822, parte do território das terras brasileiras era dominada por Portugal e parte pela Espanha e como forma de administração, foi criado o regime das Capitanias Hereditárias ${ }^{3}$ dividindo as terras ao longo do litoral brasileiro em Capitanias, sendo que, a partir de 1532, inicia-se a exploração e ocupação dessas terras.

\footnotetext{
${ }^{3}$ As Capitanias Hereditárias referem-se aos acordos de divisão de terras estabelecidos entre Portugal e Espanha, em que as terras brasileiras eram dividas em linhas imaginárias e doadas para administração.
} 
O direito de administração das Capitanias não era dado a qualquer pessoa, mas sim, a pessoas de interesses do trono, como argumenta Faoro (2001), pois o objetivo da Coroa era manter a defesa do território e manutenção do poder sobre ele. Destaca o autor que a Coroa "Selecionou, para guardar seus vínculos públicos com a conquista, pessoas próximas do trono, burocratas e militares, letrados ou guerreiros provados na Índia, a pequena nobreza, sedenta de glórias e riquezas". (p.143).

No entanto, a estratégia das Capitanias não foi viável, e Faoro (2001) sintetiza essa discussão mostrando que o mecanismo não estava dando os lucros esperados e, portanto, trataram de criar outro mecanismo como foi o caso do sistema de Governo Geral.

O novo sistema criado em 1548 pela Coroa, com o objetivo de melhor administrar o Brasil colônia, teve entre os governadores, Tomé de Souza (1549 a 1553), Duarte da Costa (1553 a 1558), e Mem de Sá (1558 a 1572). Fausto (2010) registra que, junto com o primeiro governador, chegaram os primeiros jesuítas Manoel da Nóbrega e seus companheiros com a missão de catequizar os indígenas, inculcar-lhes a cultura dominante da Europa, tornando-os mais sensíveis aos objetivos da Coroa.

As formas de administração por meio das Capitanias e do Governo Geral foram, na visão de Faoro (2001), medidas estabelecidas para garantir que o lucro da produção e exploração das novas terras não se desviasse das mãos da Coroa. Por conseguinte, o Brasil, enquanto território colonizado vai sendo moldado servilmente para atender e obedecer a ordens. Andrade (1999) reafirma que, "desde o início, a colonização foi realizada com o intuito de tornar a colônia uma fonte produtora de riquezas". (p.202).

$\mathrm{Na}$ medida em que o território vai sendo colonizado, as riquezas naturais também vão sendo exploradas e o povo, a população indígena brasileira, é forçada a trabalhar nessa exploração para obtenção de riquezas para a Coroa Portuguesa. Além dos índios, muitos negros africanos foram trazidos para o trabalho escravo no Brasil. Importante lembrar, como destaca Fausto (2010), que os nativos não aceitavam as condições impostas sem resistir e lutar, ao contrário dos negros.

Os índios resistiram a várias formas de sujeição, pela guerra, pela fuga, pelo trabalho compulsório. Em termos comparativos, as populações indígenas tinham melhores condições de resistir do que os escravos africanos. Enquanto esses se viam diante de um território desconhecido onde eram implantados à força, os índios se encontravam em sua casa. (p.44).

Entre as riquezas exploradas, destacam-se o pau-brasil, a cana-de-açúcar e o ouro, entre outros que se sobressaíam como produtos que geravam muito lucro e atraíam o interesse 
de outros países europeus, os quais não mediam esforços para também obter lucros com as novas terras, travando assim lutas com Portugal e Espanha, o que levou, ao mesmo tempo, ao processo de interiorização e ocupação portuguesa pelas terras brasileiras, mas também ao esgotamento da ordem vigente.

Fausto (1995) apresenta uma síntese do período Brasil colonial, dividindo-o em três momentos que expressam o processo de posse, colonização e exploração no território brasileiro.

Podemos dividir a história do período colonial em três períodos muito desiguais em termos cronológicos: o primeiro vai da chegada de Cabral à instalação do governo geral, em 1549, o segundo é um longo lapso de tempo entre a instalação do governo geral e as últimas décadas do século VXIII, o terceiro vai dessa época à Independência, em 1822. [...] o primeiro período se caracteriza pelo reconhecimento e posse da nova terra e um escasso comércio. Com a criação do governo geral inicia-se uma montagem da colonização que irá se consolidar ao longo de mais de dois séculos, com marchas e contramarchas. As últimas décadas do século VXIII são referências para indicar um conjunto de transformações na ordem mundial e nas colônias, que dão origem à crise do sistema colonial e aos anseios pela independência. (p.41).

Na concepção de Faoro (2001), o processo de colonização brasileira tratou de um negócio político planejado pela Coroa portuguesa, "foi obra do Estado" (p.130). Assim, destaca que todo o processo de Capitania e de feitorização tinha como objetivos consolidar os interesses comerciais, ou seja, "interesses comerciais, triunfantes na Europa e derivados dos valores que assoberbavam o reino, que ditam, por meio do Estado, a exploração social e econômica do Brasil”. (p.130).

Nas palavras de Faoro (2001), eis como fica evidenciado o interesse comercial para com o Brasil,

Dom João III (1521-57) inaugura o sistema americano de exploração mercantil, a um tempo dirigido contra a concorrência europeia e contra a dispersão do litoral. A linha fundamental, de caráter mercantil, seria a de encolher o espaço da exploração econômica aos tentáculos burocráticos. $\mathrm{O}$ Brasil, tal como a Índia, seria um negócio do rei, integrado na estrutura patrimonial, gerida pela realeza, versada nas armas e cobiçosamente atenta ao comércio. Nada - nem a ilusão dos historiadores, nem a dispersão do território imenso - afastará a empresa de Portugal de suas diretrizes fundamentais, plantadas pelas mãos de dom João I. (FAORO, 2001, p.127).

Dessa forma, o autor entende que a colonização tratou, desde seu início, de uma questão de ordem econômica: "A empresa colonizadora, da qual as capitanias foram a 
primeira expressão de grande envergadura, tem nítido, claro, inconfundível caráter capitalista”. (FAORO, 2001, p.130).

Predominou, nesse período, um modelo de Estado centrado nas concepções de uma política econômica mercantilista do Estado português, modelo que, por sua vez, entrou em crise. Fausto (1995) lembra que tanto a prática quanto a teoria dessa política partiam do princípio de que "não há ganho para um Estado sem o prejuízo do outro", (p.55) e para tanto, o Estado tinha que atrair a maior quantidade de estoque que conseguisse e, sempre que possível, devia criar mecanismos de proteção, como a criação de impostos, proibição de comércio, dentre outros, o que reforçava a característica de um Estado intervencionista.

Importante também lembrar que, nessa época, o Estado está intimamente ligado à Igreja Católica e ambos têm papel fundamental no processo de colonização do Brasil. Destaca Fausto (1995) que cabia ao Estado, inicialmente, o papel de "garantir a soberania portuguesa sobre a Colônia, dotá-la de uma administração, desenvolver uma política de povoamento, resolver problemas básicos". Esse papel dava ao Estado certa autoridade que era reconhecida pelos colonizadores.

Com relação ao papel da Igreja, o autor destaca sua função de educar, sobretudo para obtenção de obediência dos indivíduos ao poder do Estado e, ainda, pela ideologia pregada sobre a garantia de vida e morte. A Igreja estava presente na "vida e na morte das pessoas, nos episódios decisivos do nascimento, do casamento e morte" (FAUSTO, 1995, p.60). No caso português, a Igreja esteve subordinada ao Estado por meio do "Padroado Real"4.

Assim, tratou-se de um Estado Absolutista em que "todos os poderes divinos concentram-se na pessoa do rei” (p.62), ou seja, tudo estava sob o patrimônio do reinado português, portanto, também um estado patrimonialista em que não havia limites para o poder do rei. Roio (1999) entende que o Estado, nesse período, não teve uma nação e uma cidadania, dadas suas características de exclusão dos índios e escravos negros da vida civil e política, a não ser que esses termos se refiram aos grandes latifundiários e suas famílias, donas do poder.

Após anos de dominação de Portugal ao Brasil, elites brasileiras começam a resistir e mostram-se insatisfeitas com o modelo de Estado absoluto e começam a exigir o fim do monopólio comercial e mais autonomia. Esse processo, dentre outras características, representou a "crise do sistema colonial", pois passam a ser questionadas as condições

\footnotetext{
${ }^{4} \mathrm{O}$ padroado consistiu na concessão da Igreja de Roma ao Estado português, em troca de garantia de que a Coroa promoveria e asseguraria os direitos e a organização da Igreja em todas as terras descobertas. O Rei ficava com o direito de recolher o tributo devido pelos súditos, o dízimo. (FAUSTO, 2010, p. 29).
} 
históricas e sociais pelas quais se organizou o processo de colonização do país. Com isso, surgem várias rebeliões e revoltas na colônia contra o poder absolutista de Portugal.

Vários são os movimentos registrados pela história brasileira, cujos objetivos eram a busca pela independência por um país com seu governo e leis próprias, o que necessariamente também implicava a reestruturação política e administrativa do Estado, o que só foi ocorrer, depois de vários embates e uso da força armada, sendo proclamada a independência em 1822 e instaurado o período conhecido de Brasil Imperial.

Importantes são os marcos e acontecimentos relacionados ao processo de Independência do Brasil. Sem querer desmerecer a discussão necessária sobre o assunto, mas atendo-se ao objeto em estudo, passamos a compreender algumas características mais gerais do Estado brasileiro nesse novo período da história.

Entre 1822 a 1889 o Brasil Imperial foi estruturado por um modelo de monarquia hereditária em que o poder real era transmitido de geração a geração. Esse modelo de governo, como mostram Vieira e Freitas (2003), foi bastante conturbado, em especial, porque a Independência ocorre sem rupturas significativas com Portugal. Na verdade, Andrade (1999) pontua que até hoje a Independência não foi conquistada no Brasil.

Durante o período de governo de Dom Pedro I (1822 a 1831), destaca-se o clima de desequilíbrio político entre os brasileiros e o Imperador, marcado por constantes conflitos por vários motivos, dentre eles, a insatisfação de portugueses pela independência; o envolvimento do Imperador nos encaminhamentos da primeira Constituição; a falta de popularidade e de apoio político, dentre outros motivos, levando-o à renúncia.

O excessivo envolvimento do Imperador na política portuguesa, aliado aos episódios relativos à Constituição de 1824 , assim como a malsucedida Guerra da Cisplatina, com a consequente perda da região, acabam por diminuir sua popularidade, minando as suas bases de apoio. Em 1830, o assassinato de um jornalista oposicionista (Libero Badaró), em São Paulo, é atribuído ao mando de autoridades ligadas às tropas imperiais, provocando o afastamento dos liberais do governo. Sem sustentação política, D. Pedro acaba por renunciar ao trono em favor de seu filho, retomando a Portugal em abril de 1831. (VIEIRA, FREITAS, 2003, p.51).

Após renúncia, alguns governos em nome do Imperador, assumiram o trono no período de 1831 a 1840 até que o herdeiro, o qual ainda era criança pudesse assumi-lo. Por sua vez, esses governos também se defrontaram com vários problemas políticos e econômicos, entre os quais, como destacam Vieira e Freitas (2003), "os anseios de independência por parte das províncias, os desequilíbrios entre as regiões e o empobrecimento da população" (p.51), problemas agravados pelo "vácuo do poder". 
Fausto (1995) argumenta que esse período foi um dos mais agitados da história política do país, pois esteve em jogo a "unidade territorial do Brasil" e os debates políticos da época se concentravam em torno das questões de "centralização e descentralização do poder, do grau de autonomia das províncias e da organização das Forças Armadas”. (p.161).

Importantes reformas institucionais e revoltas provinciais ocorreram nesse período. As reformas buscavam reestruturação nas atribuições dos órgãos da Monarquia e a revisão no papel do Exército. Já as revoltas, como pontua Fausto (1995), surgiram em respostas às dificuldades diárias e incertezas da organização política. Dentre elas, destacam-se a Guerra dos Cabanos em Pernambuco; a Cabanagem no Pará; a Sabinada na Bahia; a Balaiada no Maranhão e a Guerra dos Farrapos no Rio Grande do Sul. Em meio às rebeliões, o país ia definindo suas tendências políticas a partir de dois partidos imperiais, que eram o Conservador e o Liberal.

O período posterior $(1840$ - 1889) com Dom Pedro II no governo, refere-se a um momento menos turbulento, considerado pelo processo de consolidação da Monarquia. No entanto, politicamente, os temas em torno da "centralização e descentralização" do poder ainda eram recorrentes tendo em vista que diziam respeito à organização do Estado brasileiro e que levou à consolidação dos dois partidos imperiais, os quais foram consolidados em 1830 .

A respeito dos partidos, o Conservador e o Liberal, Fausto (1995) questiona até que ponto eles apresentavam diferenciações ideológicas, lembrando que, por exemplo, nas eleições, interessava aos partidos obter prestígios e benefícios para si e para os partidários. Assim, conservadores e liberais utilizavam as mesmas estratégias políticas, autoritárias e patrimonialistas, "concedendo favores aos amigos e empregando a violência com relação aos indecisos e aos adversários”. (FAUSTO, 1995, p.181).

Além dessas questões, a política do Império precisava organizar o Estado e, nesse sentido, também estava em discussão o tema da não unidade territorial do país, lembrando que com a Independência essa questão não estava resolvida e, por isso, houve continuidade das rebeliões e revoltas ainda nesse período, tendo em vista o interesse de manutenção por um Estado centralizador. O Brasil Império, marcado pelas raízes portuguesas, com a falta de rigidez na sua estrutura social e a forma hierarquizada do poder, reforçava a manutenção da desigualdade em oposição à unidade.

Essas características levam à constituição de um Estado patrimonialista em que era comum, entre outras marcas, a não separação entre as esferas do público e de privado e a manutenção dos interesses particulares, sobretudo das elites. Na linha de raciocínio usada por 
Fausto (1995), baseada em José Murilo de Carvalho, essa questão da elite fica muito evidenciada como uma das respostas que determina as características do Estado centralizador e conservador em que se tornou o Brasil.

[...] uma parte significativa da elite política era constituída de magistrados. Desse modo, a profissão contribuiu para aumentar os índices de homogeneidade da elite política, em termos de visão do mundo, interesses e objetivos a serem alcançados. A elite que assumiu o poder e foi, ao mesmo tempo, se constituindo no Brasil pós-independência, possuía características básicas de unidade ideológica e de treinamento que não estavam presentes nas elites de outros países. Apesar de não ser nada representativa do conjunto da população, teve condições de realizar uma política de construção de um Estado centralizado e conservador, que acabou por assegurar a unidade do país. (FAUSTO, 1995, p.184).

Nesse sentido, os ideais de um Estado Liberal, tal como anunciava Rousseau e os clássicos do liberalismo, são muito tímidos no Brasil devido à sua organização centralizadora e autoritária. Mesmo quando há rumores de oposição a essa característica histórica, há uma falta de equilíbrio político como afirma Schwartzman (1998).

Para esse autor, vivemos em constante contradição e num dilema, pois a sociedade civil ainda não conseguiu criar um sistema político que pudesse de fato romper com as raízes de um Estado tão centralizador. Ao tentar opor-se ao sistema, confundem-se e misturam-se dois tipos de problemas, sendo um que aparece como "contraste entre Estado patrimonial" e os "setores da sociedade" que se denominam mais autônomos e racionais, e outro como sendo "contraste entre ideologias liberais de não intervencionismo" e a "intervenção do Estado na vida econômica e social do país". (SCHWARTZMAN, 1998, p.10).

Ao mesmo tempo em que se pretende desenvolver uma perspectiva liberal em que o Estado não deve controlar a sociedade, pois os setores sociais devem ter mais autonomia e ter seus direitos respeitados, essa mesma perspectiva nega esses direitos. Essas características embora datem da origem do Estado Brasileiro, estão presentes até os dias atuais na sua versão mais moderna do neoliberalismo.

[...] O Estado não deve se sobrepor à sociedade e controlá-la [...] é importante que os setores sociais mais dinâmicos e dotados de recursos próprios e autonomia tenham o direito e a oportunidade de se fazer ouvir e se fazer valer. Ao mesmo tempo, no entanto, essa perspectiva liberal nega a validade do planejamento social, da intervenção do Estado na vida econômica, da possibilidade de definição de valores sociais e nacionais que sejam superiores à simples agregação de interesses privatizados. Ela se confunde, assim, com a defesa do status quo, como a manutenção de privilégios econômicos, com o conservadorismo enfim. (SCHWARTZMAN, 1998, p.10). 
Importantes acontecimentos econômicos e sociais marcaram o período, como a abolição da escravidão, a adoção do trabalho livre, o crescimento urbano e industrial como resultado do início da industrialização, dentre outros acontecimentos, no entanto o Brasil continua com as mesmas práticas e modelos de economia da época colonial. "O poder continuou centralizado no imperador e as riquezas concentradas em mãos de poucos". (ANDRADE, 1999, p.208). (grifos do autor).

As características destacadas até então acompanham a evolução do Estado brasileiro e vão tomando novas feições, ganhando nomes diversos. No período do Brasil República que inicia em 1889 e vigora até os dias atuais, embora tenha mudado o regime político da Monarquia para a República, as marcas de autoritarismo e conservadorismo e as disputas pelo poder, ainda continuam.

Iglésias (1989) lembra que, desde a derrubada da Monarquia, já houve um golpe militar. O autor destaca a participação do exército na vida da política do Brasil república, embora reconheça que o novo regime teve um apoio muito grande das elites brasileiras. No entanto, chama atenção para o caráter autoritário e excludente do Estado brasileiro, o qual garante privilégios para as classes dominantes e nega direitos às classes exploradas durante muito tempo da sua história.

O Brasil República, segundo os historiadores, pode ser dividido em República Velha ou Primeira República (1889-1930), Era Vargas (1930-1945), República Populista (19451964), Ditadura Militar (1964-1985) e Nova República (1985 aos dias atuais). De forma geral, nesse novo regime, implanta-se o Federalismo, o sistema Presidencial, a independência dos poderes, tem-se a separação do Estado e a Igreja e extingue-se o sistema de hierarquia do poder.

O quadro político no período da Primeira República destaca-se pela presença dos militares, pela votação da Constituição de 1891, pela organização do Brasil em 20 estados, os quais eram as províncias antigas. Destaca-se também pelo modelo de eleição ${ }^{5}$ direta para presidente da República, dos deputados e senadores, tendo em vista que os cinco primeiros anos foram governados por militares, Deodoro da Fonseca e depois Floriano Peixoto. (IGLESIAS, 1989).

Após o governo desses militares, também conhecido como Republica da Espada, o Brasil foi governado por representantes da elite agrária, presidentes civis já eleitos no período

\footnotetext{
${ }^{5}$ Interessante ressaltar que o voto não permitia a participação de mulheres, analfabetos e militares de baixa patente. Marcas do autoritarismo e conservadorismo brasileiro.
} 
conhecido como Republica Oligárquica. Nesse contexto, surge a "Política dos Governadores" visando garantir o apoio dos governadores ao presidente e em troca desse apoio, garantiriam que os opositores não chegariam ao poder.

Ao lado dessa política tem-se a "Política do Café com Leite" em que o poder se alternava, ora pelo Partido Republicano Paulista, ora pelo Partido Republicano Mineiro. Os partidos controlavam as eleições, criavam políticas que beneficiavam os grandes fazendeiros e latifundiários. Essas ações demonstram a continuidade das práticas patrimonialistas do Estado brasileiro e a negação dos ideais republicanos, mantendo o domínio dos interesses de um grupo hegemônico, o que Iglésias (1989), vai chamar de federalismo distorcido.

O federalismo distorcido explica o fato. Sua projeção é a "política dos governadores" ou "dos Estados", inaugurada por Campos Sales, representando a negação dos ideais republicanos e o desvio do sistema federal. Em consequência da troca de favores, institucionalizada - os poderes dos Estados e da República se complementam em suas pequenas e grandes ambições, com o desconhecimento do povo -, fortalecem-se as oligarquias, atinge o auge o coronelismo. Formam-se no Congresso as bancadas de total apoio à política oficial. É o exemplo mais consumado da política de conciliação na história do Brasil - conciliação dos dirigentes sem respeito à vontade popular. [...] A máquina atua com perfeição, constituindo os famosos vícios da República Velha, oligárquica e fundamentada em falsificações [...]. (p.258-259).

Em oposição a esse modelo de governo, surgiram diversos conflitos e revoltas dentre elas a Revolta da Armada (1893-1894), Revolução Federalista (1839-1895), Guerra de Canudos (1893-1897), Revolta da Vacina (1904), Revolta da Chibata (1910), Guerra do Contestado (1912-1916), Greves Operárias (1917-1919), Revolta dos Dezoito do Forte (1922) e a Revolução de 1930.

Esses acontecimentos levaram a eclosão do movimento Tenentista, formado por um grupo de oficiais ou de "ramos empobrecidos de famílias de elite do Nordeste" (FAUSTO, 1995, p.315), que defendiam mudanças no sistema eleitoral para que o mesmo fosse mais democrático, na moralidade política e educacional do país. No entanto, não se tratou de novos rumos para o Brasil. O movimento embora tenha conquistado a adesão de muitos civis em busca de um bem comum para o país, foi mostrando seus objetivos de reestruturação de um Estado forte e centralizado.

Fausto (1995) pontua que o movimento Tenentista tem que ser lembrado por sua história antes e depois dos anos de 1930, pois os dois períodos possuem diferenças importantes, sendo que, no primeiro, tratou-se de uma reação contrária ao governo da 
República e, no segundo, depois de “30”, os Tenentes passam a fazer parte do próprio governo, mudando sua estrutura de forma a alcançar os objetivos do movimento.

No fundo, pretendiam dotar o país de um poder centralizado, com o objetivo de educar o povo e seguir uma política vagamente nacionalista. Tratava-se de reconstruir o Estado para construir a nação. $\mathrm{O}$ grande mal das oligarquias - pensavam eles - consistia na fragmentação do Brasil, na sua transformação "em vinte feudos" cujos senhores são escolhidos pela política dominante. (FAUSTO, 1995, p.314).

O autor destaca que, nos anos "1920", os Tenentes não tinham uma proposta clara de reestruturação da política existente e, na verdade, os ideais do movimento davam continuidade aos interesses para solidificar as raízes de um Estado com poder centralizador, visando a uma reforma do Estado e da sociedade pela via autoritária e uma educação voltada para o sentimento nacionalista.

As características do Estado brasileiro vão sendo ressignificadas com o passar dos acontecimentos históricos e políticos e, apesar de serem tímidas as mudanças, após os anos de 1930, com os movimentos nacionais e internacionais, é possível vislumbrar novos caminhos, sobretudo com a entrada de Getúlio Vargas no poder e com o processo de industrialização do país. O período que vai de 1930 a 1945 é conhecido como era Vargas. Em 1950, Getúlio retorna à presidência pelo voto direto, porém comete suicídio antes de concluir seu mandado.

Nomeado como presidente após a deposição de Washington Luiz, Getúlio Vargas assume e obtém poderes que lhe permitem fazer mudanças expressivas, sobretudo econômicas e sociais no país com vistas à modernização do Estado brasileiro. Seu período de governo foi dividido em Governo Provisório (1930-1934), o Governo Constitucional (1934-1937) e o Estado Novo (1937-1945).

Dentre as tarefas desempenhadas no governo de Vargas, destaca-se a criação da “Companhia Siderúrgica Nacional (CSN-1941); o Ministério do Trabalho, Indústria e Comércio (1931) e assegura direitos trabalhistas (1943)". (VIEIRA, FREITAS, 2003, p.87). Vargas teve que enfrentar diversos problemas internos e externos a seu governo e, dentre eles, destaca-se o próprio Tenentismo. Embora esse movimento tenha apoiado a entrada de Vargas ao poder, eles tinham seus interesses e ideias próprias, o que levou a disputas políticas no governo, sendo esse o vencedor.

Com relação aos problemas externos, Fausto (1995) destaca questões relacionadas com as elites dos Estados inconformados com a política centralizadora de Vargas, como foi o caso da elite paulista, cujos resultados levaram à Revolução de 1932, “Constitucionalista”, em 
que as bases do governo venceram. Vale lembrar a criação de duas novas Constituições, sendo que a de 1934 dá as bases para eleição de Vargas ao poder após o período do Governo Provisório e outra que se refere à Constituição de 1937 e coincide com o golpe de Estado conhecido por Estado Novo.

Essa fase de governo de Vargas é considerada a mais ditatorial e repressiva, sendo revogada a Constituição de 1934, suprimindo a liberdade partidária, a independência entre os três poderes e o Federalismo e privando o país de eleições e de liberdade de expressão, além de apoiar ideais fascistas inspirados nos líderes autoritários europeus da mesma época como Mussolini e Hitler. Por outro lado, destaca-se a criação das leis trabalhistas por meio da CLT (Consolidação das Leis do Trabalho), aprovada em $1^{\circ}$ de maio de 1943 e presente até os dias atuais. No âmbito legislativo, estabeleceu o Código Penal e o Código de Processo Penal.

Sobre esse período, Iglésias (1889) apresenta detalhamentos importantes:

De fato, a legislação trabalhista é dádiva ao trabalhador, não conquista em luta. Daí o salário mínimo, jornada regular, estabilidade, férias, indenização por dispensa não justificada, regulamentação do trabalho da mulher e do menor, institutos de aposentadoria e pensões. A assistência se consolidava. Formava-se a imagem de Vargas como amigo do grupo, o "pai dos pobres", o qual tanto lhe valeria no futuro. A tutela significa, é obvio, submissão, passividade do grupo, controlado por agentes do Ministério do Trabalho, ao mesmo tempo que impossibilidade de qualquer organização operária livre, cortando pela raiz as perspectivas ou projetos socialistas [...]Ao longo prazo, terá feito mais mal do que bem ao trabalhador. (p.275).

Em 1945, Getúlio Vargas foi deposto por um golpe militar, porém em 1951, retorna à Presidência pelo voto popular. Dentre algumas características do curto tempo de governo, destaca-se o lançamento das bases para criação da Petrobras. Vargas suicidou-se no Palácio do Catete em agosto de 1954, com um tiro no peito, deixando os dizeres: "Deixo a vida para entrar na História". (FAUSTO, 1995).

Outro momento importante no período "Brasil República" é o chamado de República Populista, Período Democrático ou ainda de República Liberal (1945-1964). É assim denominado pelos historiadores por marcar, um breve período entre as duas ditaduras vividas pelo país e que dificultou os ares democráticos no Estado brasileiro. Uma nova Constituição é aprovada, a de 1946, com fortes princípios liberais e democráticos.

Nos anos de 1964 a 1989, o país volta a conviver com governos ditadores e repressores no novo regime militar, marcado por restrições aos direitos e garantias individuais, pelo uso da violência aos opositores do regime, pela centralização do poder. Os 
governos preocupavam-se com a segurança nacional; editaram vários atos institucionais; promoveram diversas mudanças no Estado e sua estrutura de funcionamento, proclamando nova Constituição, agora a de 1967.

Importante lembrar que paralelo a esses acontecimentos no Brasil, na Inglaterra e outros países europeus, ganha terreno as experiências com o neoliberalismo econômico por meio da reestruturação do capital em busca de formas mais flexíveis de governança.

No Brasil, destaca-se a nova forma de Estado alcançada, denominada de Nova República, com a eleição de presidentes civis ao poder; a busca pela redemocratização do país; por liberdades sociais e de impressa; a promulgação de Constituição de 1988; as eleições diretas para presidente da República a partir de 1990; tentativas de criação de programas sociais para população carente e o destaque para a grande expressão do país no cenário externo.

Em contrapartida, enquanto o país está avançando, sofre outro golpe, o da investida do neoliberalismo, da globalização e reestruturação produtiva, como sinaliza Peroni e Caetano (2012).

No entanto, quando o país estava avançando alguns passos na participação popular e na luta por direitos sociais, sofreu o impacto das estratégias do capital para superação de sua crise: neoliberalismo, globalização e reestruturação produtiva, que já estavam em curso no resto do mundo e vinham em sentido contrário a esse movimento. (p.58).

Esse golpe pode ser bem visualizado nas políticas adotadas desde o governo do presidente Fernando Collor de Melo. A forma como esse presidente chega ao poder é marcada por acontecimentos importantes desde 1985, quando Tancredo Neves é eleito, mas nem sequer assume o poder, morrendo antes de sua posse. Assume o vice José Sarney que marca entre suas ações, o processo de transição do militarismo para o retorno do Estado democrático. Em seguida, assume a presidência Fernando Collor de Mello, permanecendo no poder apenas dois anos, de 1990 a 1992.

No entanto, como argumentam Vieira e Freitas (2003), trata-se de tempos em que não há projetos bem definidos, "o consenso desta fase inicial, em verdade, é a vontade política de mudar e de estabelecer a plenitude do estado de direito". (p.144). Trata-se de tempos muito atuais vivenciados pelo Brasil, tendo a frente do governo os presidentes Itamar Franco (1992 - 1994), Fernando Henrique Cardoso (1995- 2002), Luiz Inácio Lula da Silva (2003-2010) e Dilma Rousseff (2011-2016). 
A respeito desses períodos de governos e visando compreender características do Estado brasileiro, vamos nos ater a alguns elementos que demarcam, nos últimos 30 anos, a presença do país no contexto da nova ordem mundial.

De uma maneira bem geral, é possível visualizar como que as múltiplas determinações históricas, políticas e sociais, ajudam a compreender a origem do Estado brasileiro, bem como as marcas que ele carrega das continuidades em torno do autoritarismo, conservadorismo e centralismo do poder. Da condição de Monarquia Absoluta, passa pelos ideais de um Império marcado por laços de hereditariedade vitalícia, chegando ao Brasil República na tentativa de se constituir como um Estado livre, autônomo, independente e democrático.

Essas e tantas outras determinações implicam pensar que marcas dessas naturezas também são encontradas na forma de elaboração e na gestão das políticas públicas educacionais no país. Mas deixemos essa discussão para outro momento. Continuemos a compreender as novas ou velhas nuances que levam a consolidação do Estado brasileiro.

Fausto (1995) ressalta que o Brasil dos anos XX, apesar de grandes mudanças e transformações no papel e na função do Estado, ainda não pôs fim às suas marcas de autoritarismo e centralismo do poder, mas reconhece que o caráter delas sofre algumas mudanças para acompanhar as transformações mundiais.

Tendo em vista o processo de industrialização, globalização da economia, revolução tecnológica, e entre outros acontecimentos, o novo ideário liberal que marca a economia e política, nos dias atuais, o Brasil se vê na condição de acompanhar esse movimento, embora sob condições nada fáceis, como destaca Fausto (1995), pois é um Estado que vem sofrendo alterações no seu papel.

Se o Brasil conseguir sair de um quadro imediato difícil, terá de enfrentar questões amplas que não se reduzem à retomada do crescimento. Há uma série de interrogações sobre a qual deve ser o modelo de desenvolvimento sobre a inserção do país no mercado internalizado, sobre o caminho para começar a reduzir as desigualdades sociais. Uma das questões mais importantes é a da recuperação do Estado e da redefinição de seu papel. O Estado brasileiro, dilapidado por elites espertas e sob o peso burocrático, quebrou no final dos anos 80 . Sua máquina apodreceu em várias partes. (p.555).

Considerando os vários acontecimentos após o período de ditadura e após as eleições presidenciais de 1889, da morte do presidente Tancredo Neves, da posse do vice José Sarney, da eleição de Fernando Collor em 1990 e sua deposição por meio do Impeachment em 1992, o 
país necessita de muito fôlego para se reerguer enquanto uma nação que busca consolidar os princípios democráticos.

Vieira e Freitas (2003) destacam o período de governo de Collor como sendo uma "caixa de surpresas", e dentre as causas, tem-se a interrupção do seu mandato motivado por escândalos de corrupção e porque, mesmo em curto período de tempo, consegue fazer grandes mudanças na vida econômica dos brasileiros.

Tendo chegado ao poder através de promessas de campanhas voltadas para a modernização política e o fim da inflação. [...] Conforme prometera, no dia seguinte à sua posse, Collor lança um programa de estabilização que surpreende o País. O conjunto de medidas adotadas envolve desde um confisco monetário sem precedentes ao congelamento de preços e salários, extinção de órgãos públicos, demissão de funcionários e venda de patrimônio público. (p.151).

Dentre as promessas de campanha eleitoral, têm-se os planos de modernização do Brasil, da liberdade de mercado e a promoção de livre competição econômica, elementos que integram as tendências do neoliberalismo nas ações de reestruturação econômica do país as quais são formuladas a partir das diretrizes de organismos multilaterais.

Antunes (2005) destaca que Collor se elegeu tendo como base um projeto de modernização, o qual contempla uma "integração subordinada do Brasil nos marcos do mundo capitalista avançado. Fundado num ideário neoliberal para um país de Terceiro Mundo". No entanto, as marcas iniciais desse projeto são de uma "brutal reestruturação do país, levando à desindustrialização" do pouco que o país havia conseguido se industrializar. (p.16-17).

Roio (1999) também pontua que, desde as eleições para presidente da República de 1989, já se tinha marcos importantes da entrada do projeto neoliberal no Brasil.

As eleições presidenciais de 1989 representam um momento decisivo no projeto de reforma neoliberal do Estado brasileiro e no esforço de dar passagem a um novo padrão de acumulação, intimamente vinculado ao capital financeiro global. [...] A iniciativa do próprio Estado na sua reorganização neoliberal ficou patente desde logo com o saque da poupança pública feita pelo governo. As iniciativas em favor da abertura dos mercados brasileiros e a abolição das defesas internas, associadas a transferências de empresas públicas para o capital privado nacional e internacional, demarcaram o novo rumo. (ROIO, 1999, p.10).

No entanto, o resultado do curto governo de Collor não foi positivo para que as reestruturações ocorressem. Surgiram denúncias de desvios de verbas públicas, denúncias de relações de parentescos e de pessoas de confiança na política. O resultado foi o aumento da 
recessão econômica e o crescimento da inflação o que levou o povo, especialmente os jovens, à realização de protestos pelas ruas do país. Os partidos políticos souberam aproveitar esse momento e conseguiram o impeachment do presidente.

Martins (1994), por sua vez, entende que o caso de corrupção que veio a público com o presidente Collor trata-se mais de uma conformação da opinião pública, pois na verdade, casos de corrupção e maus tratos com o dinheiro público e relações de parentesco na política é uma prática comum na tradição brasileira. Lembra o autor que "a política do favor, base e fundamento do Estado brasileiro, não permite nem comporta a distinção entre o público e o privado". (p.20).

Nesse sentido, esse autor ressalta que, para compreender o processo político brasileiro, é preciso entender que a mudança só tem sentido quando se considera o contexto de "crises e descontinuidades do clientelismo de fundo oligárquico que domina o País", (MARTINS, 1994, p.20), tendo em vista que o Brasil tem sua origem numa base contraditória e que ao mesmo tempo combina interesses e concepções tradicionais e modernas.

O vice Itamar Franco assume a presidência em 1992 e, dentre as realizações de seu governo, destaca-se o plebiscito para consulta pública sobre a forma e sistema de governo que, como resultado, permaneceu a Republica Federalista. Além disso, foi apresentado o Plano Real pelo ministro da fazenda Fernando Henrique Cardoso (FHC), o qual foi candidato à presidência e venceu as eleições, assumindo o poder em 1995.

Sobre o governo Itamar, Antunes (2003) lembra que ele foi marcado por dualidades e ambiguidades, embora o quadro político lhe fosse muito favorável. Precisou aceitar o projeto de modernização neoliberal e por trás de muitos discursos pró-sociais, acabou agindo de forma antissocial, "propõe o crescimento da economia", mas "intensifica a privatização", "fala em mudar muito, para, em verdade, mudar muito pouco". (p.22-23).

Dado os acontecimentos mundiais relacionados à modernização e globalização econômica, o novo presidente da República em 1995, FHC, vê a oportunidade para consolidar o projeto neoliberal a partir da promoção de reformas na estrutura estatal visando garantir meios para que o país pudesse acompanhar os novos tempos e as exigências do capitalismo contemporâneo.

O Estado é projetado a seguir novo rumo a partir de uma reforma gerencialista que se configura como um importante instrumento de difusão das mudanças e transformações requeridas pelo setor empresarial e mercadológico, e que na verdade, refere-se a uma ideologia de reafirmação de que, só pela reforma, o sistema público funcionaria com mais 
eficiência e eficácia. O discurso que se manifesta não é o de substituição do Estado pelo mercado, mas sim o de uma reforma nele para que, então, ele se manifeste, regulando o mercado.

Dentre as justificativas para essa reforma na base administrativa do Estado brasileiro, têm-se as análises dos movimentos das crises internacionais e econômicas, as causas e consequências que levaram os países a vivenciarem a Crise de Estado.

De uma forma geral, as estratégias e os discursos para a reforma da administração no Brasil representaram os anseios dos ideais neoliberais cujos fundamentos se pautam nos eixos de sustentação impostos pelos organismos internacionais e seus interesses econômicos.

No entanto, como resultados desse modelo no panorama mundial, o que se vê é o enxugamento da máquina administrativa, o desmantelamento dos serviços públicos, incentivo à iniciativa privada, o desemprego, a exclusão social, aumento da dívida externa, desregulamentação dos direitos sociais e trabalhistas, repressão aos movimentos sindicais, dentre outras marcas, até que, depois de dois mandatos de FHC no poder, é eleito Luiz Inácio Lula da Silva, um governo que representa o partido dos trabalhadores no Brasil.

Nesse governo, há esperanças que marcam um novo tipo de Estado. Trabalhadores, operários, classe média e classe pobre, vislumbraram mudanças significativas no Estado brasileiro, tendo em vista que ele representava o partido dos trabalhadores, o pensamento de esquerdistas desde o período de transição democrática nos anos de 1980 e a esperança de grupos contrários ao projeto neoliberal em vigor.

No entanto, análises de alguns estudiosos evidenciam contradições. Silva Junior (2005) e Antunes (2005) mostram que há mais continuidade com as políticas estabelecidas por FHC, havendo, na verdade, apenas uma aparente ruptura. Destaca Antunes (2005) que "o governo do PT mantém uma política econômica que aprofunda a sujeição, amplia o desemprego e a informalidade do trabalho, além de estancar a produção em benefício dos capitais financeiros". (p.166).

As próprias ações estabelecidas no pacto para eleger Lula, que ficou conhecido como “Coligação Lula Presidente”, demonstra a ligação direta com os organismos internacionais e a continuidade com as raízes burguesas. Lima (2005) aponta que,

Do discurso em defesa de um "projeto nacional de desenvolvimento" que buscava impulsionar o capital produtivo brasileiro, a candidatura Lula amplia, cada vez mais, o arco de suas alianças para a garantia de apoio aos setores do capital financeiro, destacando-se a subserviência de sua política às exigências dos acordos financeiros e políticos com organismos internacionais do capital. Essa subordinação se expressa através de sua pauta 
política: ampliação do superávit primário para pagamento (dos juros) da dívida externa; aprovação de reformas estruturais e implementação de políticas sociais de "alívio à pobreza". (p.253-254).

A autora também destaca as práticas de organizações do quadro de cargos e seus representantes, separando-os entre o "núcleo duro" e representativo do governo, pessoas de maior peso político, como Antônio Palocci e Henrique Meirelles e do outro lado, representantes de "menor peso e passíveis de cooptação", mostrando que seu projeto de governo respondia bem aos interesses de uma ordem que se repetia. "A sintonia do governo Lula da Silva com os organismos internacionais, principalmente o Fundo Monetário Internacional (FMI) e Banco Mundial (BM), tem dado o tom das políticas econômicas e sociais". (LIMA, 2005, p.258). A autora argumenta que o governo do presidente Lula se caracterizou pela "terceira geração de reforma neoliberal" no Brasil.

Saviani (2011a) também sinaliza continuidades no governo do PT, desde o primeiro mandato do presidente Lula, embora se reconheça o tom dos discursos de inovação, mas que na prática, predominou as iniciativas das reformas educativas iniciadas no governo de FHC.

Chegara, enfim, ao poder central o PT, partido que mantinha fortes ligações com os movimentos populares e que dava respaldo ao movimento dos educadores, levando ao Parlamento suas propostas de mudanças dos rumos da política educacional. [...] Esperava-se, pois, que ao chegar ao poder, se procedesse a uma sensível mudança da orientação da política educacional. [...] No entanto, os primeiros movimentos do novo governo [...] foram deixando claro que as linhas básicas de ação governamental [...] não seriam alteradas. (p.450-451).

Maciel (2013), ao fazer distinções entre o neoliberalismo, destaca que, no governo de FHC, ele se caracterizou por sua fase mais extremada. No governo Lula por sua fase mais moderada, retornando sua fase mais extrema no governo de Dilma.

Em oito anos o governo Lula foi capaz de repor e consolidar o neoliberalismo como programa político do bloco no poder; atraindo para a hegemonia do capital financeiro o apoio ativo das principais organizações do mundo do trabalho, e o apoio passivo das enormes massas de trabalhadores desorganizados, por meio do lulismo e das políticas sociais compensatórias. Além disso, a adesão do governo do PT (Partido dos Trabalhadores) ao neoliberalismo moderado esvaziou significativamente a perspectiva antiautocrática e antineoliberal alimentada pelo conjunto da esquerda e pelos movimentos sociais nos últimos 20 anos, contribuindo poderosamente para seu isolamento político e social. (MACIEL, 2013, p. 1).

No mandato do primeiro governo da presidente Dilma (2011 a 2014), essas marcas governamentais continuam como destaca Peroni e Caetano (2012). No entanto, sob novas 
roupagens. Para as autoras, tanto nos mandatos presidenciais de Lula, quanto no de Dilma, a característica do Estado gerencialista se mantém e se fortalece. Destacam as autoras:

Esses mesmos princípios de gestão estão presentes no documento "Gestão pública para um país de todos", Plano de Gestão do Governo Lula, do Ministério do Planejamento, Orçamento e Gestão (BRASIL, 2003). Esses princípios estão sendo aprofundados pelo governo Dilma Rousseff, com a criação, em maio de 2011, da Câmara de Políticas de Gestão, Desempenho e Competitividade (CGDC), presidida por Jorge Gerdau, empresário brasileiro que vem fazendo uma verdadeira cruzada para que a lógica de mercado seja incorporada à gestão pública.(PERONI; CAETANO, 2012, p.60).

Essas marcas e continuidades de políticas neoliberais dos governos brasileiros nos anos de 1990 e 2000 no Brasil são reconhecidas por alguns autores, por seus modelos alternativos, como o Novo Desenvolvimentismo ou Neodesenvolvimentismo, que se refere ao desenvolvimentismo da época do capitalismo neoliberal, marcado exclusivamente pelas ações dos governos Lula e Dilma.

O novo desenvolvimentismo surgiu no século XXI após o neoliberalismo experimentar sinais de esgotamento, e logo se apresentou como uma terceira via, tanto ao projeto liberal quanto do socialismo. Os primeiros escritos do novo desenvolvimentismo brasileiro apareceram no primeiro mandato do governo Lula no tinteiro de Luiz Carlos Bresser Pereira. (CASTELO, 2012, p. 624).

Nos governos de Lula e Dilma, o Estado brasileiro vive uma nova fase de desenvolvimento capitalista, o que, para Castelo (2012), representa uma ideologia que se propõe como guia dos novos rumos do desenvolvimentismo. Trata-se de uma frente política, “ampla, heterogênea e eivada de contradições”, como destaca Boito Júnior e Berringer (2013). É assim caracterizada por representar os interesses do Partido dos Trabalhadores no Brasil, o PT, e por ser formada por representantes da burguesia, da baixa classe média, pelo operário urbano e o campesinato, além do setor de desempregados.

As classes que compõem essa frente de desenvolvimento do país, mesmo que tenham objetivos diferentes, acabam fazendo parte desse mesmo campo político, ou seja, se tornam cúmplices das políticas e ações desenvolvimentistas, conforme argumentam Boito Júnior. e Berringer (2013).

Em processos críticos do processo político nacional, as forças que a integram agem juntas no plano político embora entrem em um conflito, muitas vezes duro, em torno de questões econômicas [...] Ora, em todos os momentos críticos [...] a sobrevivência dos governos neodesenvolvimentistas esteve ameaçada e em todos eles, importantes associações patronais [...] apoiaram os governos Lula e Dilma. (p.34). 
Embora se refira a uma frente política que, em seus discursos afirma enfrentar o neoliberalismo ortodoxo, as ações do novo desenvolvimentismo brasileiro emergiram "do seio da intelectualidade tucana que implementou o neoliberalismo no país".(CASTELO, 2012).

Maciel (2013) assim pontua:

Nos marcos da hegemonia neoliberal vigente e da própria institucionalidade
autocrática, o aprofundamento da orientação neoliberal extremada por parte
do governo do PT favorece a passividade das massas trabalhadoras
desorganizadas diante dos efeitos da crise econômica e social, de um lado, e
a criação de uma situação política e ideológica francamente hostil às
reivindicações democráticas e populares, aos movimentos sociais e à
esquerda socialista. (p. 6 )

Nesse sentido, diante das ressignificações no papel do Estado à luz do ideário neoliberal, é perceptível que há a perda, entre outras questões, dos direitos sociais, que diretamente são observados pelas práticas de criação ou omissão de políticas sociais que tenham interesse real de serem eficazes.

Peroni e Caetano (2012) lembram que a lógica do quase mercado em que estão inseridas as atividades dos setores não exclusivos do Estado, a propriedade continua sendo estatal, mas é orientada pelo capital, justificando-se que o mercado é mais eficiente e produtivo do que o Estado e, por isso, as reformas são essenciais. É nessa perspectiva de atuação do Estado brasileiro que as políticas públicas são criadas e executadas, como é o caso do Programa Nacional Escola de Gestores, nosso objeto de estudo nesta tese. Sobre a concepção e formação de políticas públicas, passamos a refletir com mais detalhes no próximo capítulo.

\subsection{Síntese do Capítulo}

Apesar da limitação com que desenvolvemos o estudo bibliográfico em torno das origens, concepções e transformações do Estado moderno e brasileiro, pois reconhecemos que um estudo mais completo merece mais aprofundamento, é possível compreendermos como em diferentes contextos históricos e políticos temos diferentes homens, diferentes ideias e concepções sobre Estado.

Nesse sentido, das distintas concepções e compreensões acerca do Estado é perceptível como algumas marcas não têm rupturas ao longo de tantos anos da história, sobretudo as 
relacionadas à não separação entre propriedade pública e privada, à centralidade do poder, à busca pelo lucro, ao desenvolvimento do individualismo, às questões econômicas, entre outros, como é evidenciado em quase todos os períodos da história do homem.

Essas marcas são aprofundadas a partir das transformações vividas pelo Estado capitalista. Por sua vez, representam muitos desafios considerando um duplo projeto de sociedade tendo em vista a divisão das classes sociais no Brasil em que há separação dos privilegiados e os desafortunados. E, segundo pontua Brzesinsk (2008), a educação e a escola brasileira, por serem herdeiras do modelo patrimonialista de Estado, mantêm essa dualidade.

A autora destaca essa dualidade do projeto de sociedade no Brasil pontuando que os projetos convivem em disputa na arena de poder das políticas educacionais:

De um lado, está o projeto da sociedade política, defendido pelos tecnocratas, que em seus discursos enfatizam a qualidade social da formação do professor, entretanto colocam em prática os princípios da qualidade total. De outro lado, encontra-se o da sociedade civil organizada em entidades educacionais reunidas no movimento nacional de educadores, cuja luta tem por princípio a qualidade social para formar docentes que atuará na educação básica. $(2008$, p.1).

Em Marx e Engels, o Estado nem sempre existiu, vindo a surgir quando, em determinado estágio do desenvolvimento econômico, apareceram as desigualdades de classes e, nesse sentido, é uma instituição que não se configura como mero mediador das lutas de classes, pois ao contrário, ele atua como um instrumento do domínio de classe.

Na perspectiva de Gramsci, o Estado é teorizado a partir de uma visão ampliada, referindo-se a um conjunto de organismos públicos que têm como função a dominação direta, quer seja no campo do consenso, quer seja no uso da coerção.

De forma geral, percebemos pelas concepções destacadas que em relação ao Estado, suas origens, seu papel e função na sociedade, sempre esteve em jogo a questão do domínio, da riqueza, do poder, da acumulação do capital, da geração de lucros, mesmo que, por um período da história, isso tenha sido feito a partir da busca de certo "bem-estar" para todos, bem-estar que, na sua conjuntura política e econômica proposta, serviam as classes hegemônicas e donas do poder e não aos operários e trabalhadores que acumulavam as riquezas para as empresas privadas e para o Estado.

Vemos, no decorrer das concepções históricas de Estado, que suas transformações seguem o curso do processo de expansão do capital, cujo movimento é social, histórico e político e que se trata de um fator que independe dos preceitos e vontade dos indivíduos e que, portanto, as consequências também vão além do esforço empreendido, como afirma Silva 
Junior (2002) que nesse movimento as "consequências nos âmbitos econômico, social, cultural, civilizatório vão sempre além das ações e metas empreendidas pelos atores, quanto à extensão da humanidade na sua dimensão genérica.” (p.19).

Diante desses apontamentos iniciais sobre o Estado, ressaltamos que nessa tese adotamos a concepção de Estado a partir da perspectiva de Gramsci da visão de Estado ampliado, ou Estado Integral. Consideramos que a política pública instituída pelo PNEGEB, nosso objeto de estudo, é um tipo de política social e faz parte de um tipo particular de Estado.

Sendo o PNEGEB uma política pública e social voltada para a formação de professores/gestores, ela representa o "Estado em ação", que como pontua Höfling (2001) "é o Estado implantando um projeto de governo, através de programas, de ações voltadas para setores específicos da sociedade" (p.2). [...] "É impossível pensar Estado fora de um projeto político e de uma teoria social para a sociedade como um todo" (p.3).

Dessa forma, o PNEGEB traduz-se como uma política que assume feições próprias do Estado capitalista atual e, ao mesmo tempo, não representa ações implementadas automaticamente, pois elas têm "movimento, têm contradições e podem gerar resultados diferentes dos esperados". (HÖFLING, 2001, p.6). 


\title{
CAPÍTULO II - AGÊNCIAS INTERNACIONAIS E OS CONSENSOS PARA AS REFORMAS NA EDUCAÇÃO
}

\author{
As ideias da classe dominante são, em todas as \\ épocas, as ideias dominantes, ou seja, a classe que é \\ poder material dominante da sociedade é, ao mesmo \\ tempo, o seu poder espiritual.
}

Marx, Engels, 2009.

\subsection{Apontamentos Iniciais do Capítulo}

Historicamente, temos acompanhando a influência de Organismos Internacionais (OIs) por meio da condução, orientação e discursos para a formulação e execução de políticas públicas de educação no Brasil, sobretudo aquelas relacionadas à formação de profissionais da educação a partir da realização de reformas.

Os OIs, entre eles o Banco Mundial (BM), a Organização das Nações Unidas para a Educação, a Ciência e a Cultura (UNESCO), a Organização para Cooperação e o Desenvolvimento Econômico (OCDE), Fundo Monetário Internacional (FMI) dentre outros, apresentam o discurso que a educação é considerada como o foco central para o desenvolvimento humano e econômico visando à diminuição da pobreza e o desenvolvimento social e os professores e gestores são os protagonistas para colocar em ação esse papel educacional.

Nesse sentido, neste capítulo discutimos mais detidamente, o que são esses OIs, como surgiram e como direcionam as políticas públicas de educação brasileira, visando demarcar elementos teóricos para compreender as determinações do PNEGEB e suas implicações para formação de coordenadores pedagógicos a partir do curso de especialização lato sensu.

\subsection{Agentes Internacionais e os Interesses com a Educação}

Ao iniciar este tópico cabe também esclarecer que não pretendemos fazer um resgate histórico e detalhado a respeito dos Organismos Internacionais, embora se reconheça a importância de tal ação. Considerando os objetivos deste trabalho, a intenção é compreender 
questões em torno da atuação desses OIs nas políticas de formação de profissionais da educação.

Vale destacar que importantes pesquisas e estudos têm sido desenvolvidos em torno desses organismos, sobretudo relacionando os efeitos, as diretrizes e as orientações para a política educacional brasileira, como destacam os estudos de Marília Fonseca, Ângela Siqueira, Maria Abádia da Silva, Ângela Gomide, dentre outros, os quais também ressaltam as relações econômicas e financeiras pelas quais esses organismos são interlocutores.

Organismos Internacionais ou multilaterais, os conhecidos OIs, referem-se à expressão conceitual dada às agências ou órgãos responsáveis por cooperações e acordos que envolvem vários países. Surgiram, sua grande maioria, no período pós a Segunda Guerra Mundial, com diferentes propósitos e objetivos, mais especificamente, com fins técnicos e financeiros de forma a prestar ajuda aos países em consequência das crises.

Bendrath e Gomes (2010) destacam quatro importantes acontecimentos mundiais que demarcam o nascimento dos OIs a partir do estabelecimento de diretrizes em forma de consensos internacionais sobre temas diversos, os quais passaram a legitimar o papel das agências multilaterais, estipulando como cumpridores dessas diretrizes, os países que necessitavam de seus financiamentos. Assim, destacam os autores:

[...] a conferência de Bretton Woods em 1944, evento que culminou com a criação do Fundo Monetário Internacional (FMI) e Banco Mundial; a assinatura da Carta das Nações Unidas em 1945, que culminou no surgimento da própria Organização das Nações Unidas (ONU); e o início das atividades da Organização das Nações Unidas para a Educação, Ciência e Cultura (UNESCO) em 1947. Assim, o estabelecimento de uma posição de consenso internacional sobre determinados temas, tendo como legitimador de tais posições, os organismos internacionais, conferiu ao Estado, em especial os mais pobres, a função de executor de programas e medidas de origem transnacional para salvaguardar a macroeconomia e assegurar $o$ desenvolvimento dentro do modelo capitalista. (p.4)

O contexto histórico e político em que ocorre o surgimento dos OIs está ligado ao movimento de crise do próprio capitalismo que, para se manter vivo, busca alternativas para se reconstruir continuamente. Quando ele entra em declínio, um novo período de ajustes econômicos é instaurado por meio do modelo de Estado de Bem-Estar Social, sobretudo considerando as crises mundiais de 1929, inaugurando a fase em que o Estado passa a exercer um papel de regulação social nos espaços políticos e econômicos da sociedade, caracterizando-se pelos princípios da social democracia, tendo o fordismo como sua principal expressão de produção econômica, conforme destacamos no Capítulo primeiro. 
Silva Júnior (2002) lembra que o fordismo se caracterizou como "um modelo estruturado em uma base produtiva com tecnologia rígida, produtos homogêneos e produção em larga escala" (p.24). No âmbito político, esse modelo propôs compromissos sociais, por meio de políticas e legislações, assim como no aspecto social, em que muitos direitos são reivindicados.

O autor também destaca que o papel do Estado é de interventor nas questões sociais e econômicas e a gestão tendia para certa forma de democratividade. "O indivíduo é envolvido na gestão pública de seu país" e elementos como "os valores 'coletivo', 'público', 'político' e 'reivindicação"”, estão presentes nesse momento, dando a impressão de cidadania e democratividade, quando ao mesmo tempo, tem-se o incentivo ao consumo: "o ser humano dessa época é o cidadão consumista: com agudo senso público, coletivo e reivindicativo". (p.28). Tratou-se na verdade de um modelo de produção frágil e por vários motivos, entrou em crise:

[...] o fordismo, depois de uma época de altas taxas de acumulação de capital, logo após a segunda Guerra Mundial, entra em declínio na década de 1970. O mercado dá sinais de esgotamento, a taxa média de lucros dos países cai em movimento contínuo, o desemprego surge e se avoluma, as taxas inflacionárias elevam-se e o ciclo fordista de acumulação mostra sua fragilidade. (SILVA JUNIOR, 2002, p. 30).

Como nos referimos no Capítulo I, novas dinâmicas e estratégias surgem para reestruturação do capitalismo em crise, as quais são baseadas nos ideais de um novo modelo de Estado a partir do neoliberalismo, por meio do qual o Estado é limitado em suas ações referentes às questões sociais.

No âmbito acadêmico, esses ideais se fortaleceram com os estudos de Hayek e Friedman, os quais criticavam o papel interventor do Estado, propondo que ele fosse mínimo, tendo suas funções reduzidas a fim de dar total liberdade para o comércio atuar.

Para esse novo modelo, a produção capitalista passa a ser orientada por meio da acumulação flexível do capital, termo utilizado por Harvey (2000) para demarcar as diferenças com o modelo rígido de produção fordista. Trata-se de um modelo baseado em novos setores de produção, novos mercados de fornecimento, novos produtos e padrões de consumo.

Nesse contexto, da nova ordem do capital estabelecida entre as tentativas de ruptura com o modelo fordista e implantação do novo modelo econômico, tem-se a origem dos Organismos Internacionais, juntamente com o modelo neoliberal de Estado. Diante desse 
cenário, os OIs passam a representar as possibilidades de sedimentação e consolidação dessa ordem emergente, que segundo Silva Júnior:

[...] tem de conviver com os traços fordistas remanescentes, e a época atual conjuga elementos do novo e do velho. Parece derivar daí a necessidade de organismos globais que, com o poder político e econômico, produzam a sedimentação da nova ordem, sob a mesma hegemonia do capital (especialmente o financeiro) no âmbito nacional e global, agora em forma diversa, num novo regime de acumulação, em diferente forma de organização social. Nesse décor, emergem os intelectuais coletivos internacionais - os órgãos multilaterais - como o Banco Mundial, o Banco Interamericano de Desenvolvimento, o Fundo Monetário Internacional, a Organização Mundial do Comércio, UNESCO, Cepal etc, com novas funções especificas voltadas para a consolidação, em nível global, da nova forma histórica do capitalismo. (2002, p.32-33). (grifos nossos).

Dentre os OIs, além dos citados: FMI, BM, UNESCO, a Comissão Econômica para a América Latina (CEPAL), Organização Mundial do Comércio (OMC), destaca-se também a Organização das Nações Unidas (ONU), Organização Internacional do Trabalho (OIT), Organização dos Estados Americanos (OEA), a Organização do Tratado do Atlântico Norte (OTAN), Organização Internacional para o Desenvolvimento Econômico (OCDE), dentre outras.

Nesse mesmo contexto, o neoliberalismo vai constituindo-se como um terreno fértil em oposição aos mecanismos do modelo de produção anterior, em especial, contrário aos movimentos e políticas sociais. Anderson (1995) destaca que ele vai se consolidando, sobretudo após a Segunda Guerra Mundial, passando a ser visto não só como uma estratégia de solução para a ordem econômica, social e política, mas também se tratando de um projeto filosófico e ideológico, atuando, por exemplo, nas políticas de educação.

Azevedo (1991) corrobora que os neoliberais veem a educação como um papel estratégico, pois, por meio dela, é possível formar e preparar indivíduos aptos aos interesses capitalistas de produção e difundir os ideais liberais, em que ela passa a ser uma organização social por meio da livre iniciativa e livre mercado.

A autora lembra que, embora a educação seja reconhecida como estratégia de mercado, é uma das poucas ações em que o Estado pode intervir, em decorrência de sua nova reconfiguração de não interventor, a partir do consenso estabelecido pelos ideais neoliberais, em que é dado novo tratamento para o sistema educacional, por exemplo, os mecanismos de descentralização tanto para divisão das responsabilidades, quanto para garantir que todos participem do financiamento da educação. 
Postula-se que os poderes públicos devem transferir ou dividir suas responsabilidades administrativas com o setor privado, um meio de estimular a competição e o aquecimento do mercado, mantendo-se o padrão de qualidade na oferta dos serviços. As famílias teriam, assim, a chance de exercitar o direito de livre escolha do tipo de educação desejada para os seus filhos. Ao mesmo tempo, minar-se-ia o monopólio estatal existente na área, diminuindo-se o corpo burocrático, a máquina administrativa e, consequentemente, os gastos públicos. (AZEVEDO, 1991, p.15)

A ênfase dos discursos neoliberais é a de que os problemas de crise do Estado estão associados à ineficiência dos modelos de gestão praticados pelos sistemas públicos e, portanto, orientam dentre as soluções as reformas na estrutura pública, para que essa se desenvolva com mais eficiência, qualidade e equidade.

O documento do Banco Mundial, "Pryoridades y Strategias para la Educacion" de 1996, declara que a educação é eixo pontencializador para o desenvolvimento econômico e suas múltiplas funções são reconhecidas e valorizadas tendo em vista, mostrar que ela é responsável para manter a ordem civil e para diminuir a pobreza dos países em desenvolvimento.

LA EDUCACION es crucial para el crecimiento económico y la reducción de la pobreza [...] ésta debe atender a la creciente demanda por parte de las economías de trabajadores adaptables capaces de adquirir sin dificultad nuevos conocimientos y debe contribuir a la constante expansión del saber. [...] De modo más general, la educación contribuye a fortalecer las instituciones civiles, a crear una capacidad nacional y a promover el buen gobierno, que son elementos esenciales para la implantación de políticas económicas y sociales racionales. (BM, 1996, p. 21).

Evidente que numa sociedade capitalista como a nossa, regida pelos interesses do capital cuja busca incessante é pelo lucro, em que o dinheiro compra, além dos meios de produção, a força de produção e a energia humana que produz o excedente para os proprietários desses meios, a educação também passa a ser objeto de interesse e desejo para que ela e, por meio dela, sejam alcançados os fins econômicos necessários para manter vivo o modelo de capitalismo.

A partir da perspectiva gramsciana, percebemos que os interesses das agências internacionais buscam a hegemonia nas políticas educacionais no capitalismo. Contudo, isso se dá num movimento contraditório, pois a política não pode ser entendida de modo monolítico sendo travada na arena política do conflito de interesses. Daí a possibilidade da guerra de posição e luta contra-hegemônica para Gramsci, conforme pontuamos no Capítulo I. 


\subsection{Banco Mundial e UNESCO: Percursos Históricos de Consensos e Intervenções na Educação}

No contexto histórico, a partir da criação e dos objetivos pelos quais foram criados os OIs e, em especial, o Banco Mundial no contexto do pós-Segunda Guerra Mundial para fins de ajuda financeira e estrutural dos países prejudicados, associado às transformações e crises do capitalismo mundial, com o surgimento de novas demandas para sua sobrevivência, percebe-se o movimento de transformações que esses organismos desenvolvem ao longo de sua existência para continuar impondo suas orientações.

Tomando como referência o BM, tem-se que, após os anos de 1960/70, é criado um departamento próprio nas instâncias do Banco para tratar dos assuntos referentes à área educacional, o qual conta com especialistas para realização de estudos e pesquisas, sobretudo durante a gestão do presidente Robert McNamara (1961-1968). Surgem os primeiros documentos direcionados às políticas de educação, como o Documento "Education Sector Working Paper" em 1973, o qual apresenta os critérios para financiamentos e as áreas que poderiam ser financiadas com relação à educação, como destaca Bastos (2014).

Silva (2000) ressalta que, em termos educacionais, já nos anos de 1971, o BM assumia os financiamentos da área educacional, reformulando e reforçando as ações iniciais e agregando a questão de avaliação do sistema educacional. Em termos de Políticas Oficialmente Declaradas - POD, vemos que o BM trabalha com os objetivos de:

[...] avaliar o potencial dos projetos para melhorar a adequação, a eficiência e a economia dos sistemas educacionais. Nesse contexto são formulados os primeiros documentos da política educacional do Banco Mundial: Educación: Documento de Trabajo sobre el sector-1971 e Educación: Documento de politica setorial -1980, Washington para dar direção a dois problemas: I- a identificação da educação como um problema e o reconhecimento da expansão da demanda, II- o combate à pobreza nos países devedores. (p.36).

Os documentos da década de 1970 enfatizam a discussão sobre a questão da pobreza e o conceito da teoria do capital humano, associando os benefícios educacionais ao crescimento econômico e financeiro e, nesse sentido, Silva (2000) é enfática ao destacar que a concepção de educação requerida pelo BM nesse período é a de "investimento industrial, expressa na racionalização dos custos, na política de concorrência e da competitividade, na abertura de mercado para a educação privada, no estímulo aos empresários de equipamentos técnicos, de informática e de produção do livro didático.” (p.37). 
As orientações para a gestão educacional desse período recaem sobre a melhoria da gestão e do planejamento educacional, já que os diagnósticos dos documentos oficiais mostravam problemas de deficiência na qualidade e ineficiência do sistema educacional. Nesse sentido, as políticas públicas têm o foco à "política de avaliação do sistema educacional, políticas voltadas para a racionalização de custos; possibilidades de novas formas de financiamento" (p.39), como pontua Silva (2000).

A autora destaca que, frente aos diagnósticos do BM sobre a ineficiência do sistema educacional entre os anos 1960/1970, a organização dos sistemas educacionais já mostrava as marcas da dicotomia entre educação para o intelecto e educação para o trabalho, revelando "as marcas da perversidade da política de equilíbrio forçado entre a formação escolar e a formação para o trabalho". (SILVA, 2000, p.4).

Nos anos de 1980 o BM se tornou o principal organismo a financiar a educação na América Latina, com destaque para o Brasil, tendo como seu gestor o presidente Clausen (1981-1986). Nesse período de atuação do BM, no que refere à gestão educacional, há ênfase nos diagnósticos apresentados pelos documentos sobre a questão da ineficiência do sistema educacional, o qual era considerado responsável pela incapacidade de assegurar qualidade, produtividade e competitividade.

As diretrizes, nesse momento, também orientam que as políticas públicas de educação devem estar subordinadas à produção e às demandas do mercado, assim como devem promover a descentralização do financiamento da gestão, reduzir os recursos, diversificar as fontes de financiamentos e reorganizar a estrutura administrativa das escolas de forma mais eficiente, flexível e com muita fiscalização, por meio de processos avaliativos.

Como estratégias para alcançar os objetivos assinalados, Silva (2000) destaca as orientações do BM para a capacitação de professores em serviço, para a contenção e diferenciação salarial dos docentes, destaca as possibilidades da escola colocar os pais mais em contato com os assuntos escolares, além do desenvolvimento de mais e melhores inovações educacionais, como o uso de equipamentos e materiais pedagógicos de forma a tornar o ensino mais eficiente.

Na perspectiva da Política de Fato - POD, Silva (2000) destaca que o Banco, por meio dos seus "técnicos economistas, guardiões dos interesses da instituição" (p.43), aqueles que deveriam ser os especialistas em assuntos educacionais, disseminam as orientações para a melhoria da qualidade educacional apoiada em um "conjunto de regulamentos econômicos do 
mercado", (p.43), além de apresentar concepções antidemocráticas, desconsiderando as realidades nacionais e culturais.

\begin{abstract}
Os técnicos e economicistas do Banco Mundial elaboram políticas e estratégias a-históricas e discricionárias, num processo de definhamento das instituições educacionais, na medida em que as mesmas são incorporadas pelo Ministério da Educação. [...] são políticas e estratégias capazes de introduzir disfunções profundas na educação pública e de colocar em escombros conquistas sociais através de fissuras permanentes, lançando a população desses países, particularmente o Brasil, para contínuos processos de desvantagens, subserviência e subordinação. (SILVA, 2000, p.43-44).
\end{abstract}

Nos anos de 1990, a gestão do BM esteve sob a presidência de James Wolfensohn. O grupo executivo em assuntos educacionais passa a produzir documentos subsetoriais considerando os diferentes níveis de educação, sem deixar de lado a ideia do combate à pobreza.

No entanto, Silva (2000) destaca que, nos documentos desse organismo no período de 1992 a 1996, os conceitos de aprendizagem e pobreza foram reconceitualizados a partir dos seus ideais políticos e ideológicos, de forma que a educação possibilitasse o fornecimento dos conteúdos mínimos e necessários para que todos tivessem acesso à aprendizagem.

De forma geral, é nos anos de 1990 que as ações do BM e outros OIs são decisivas para emplacar as suas orientações nas políticas educacionais, quando se focaliza uma série de eventos internacionais, como é o caso da Conferência Mundial de Educação para Todos, em Jontien na Tailândia.

Essa Conferência ocorreu em 1990 com o objetivo central de estabelecer estratégias e compromissos mundiais para garantir que todas as pessoas tivessem acesso aos conhecimentos mínimos, básicos e necessários a uma vida mais digna. Participaram das discussões a UNESCO e a UNICEF, com apoio do Banco Mundial e de várias outras organizações intergovernamentais, regionais e entidades não governamentais (ONGs).

Dessa Conferência, foi elaborado o documento "Declaração Mundial sobre Educação Para Todos" de 1990, no qual se definiu as novas abordagens sobre as necessidades básicas de aprendizagem, as metas a serem atingidas para a educação básica e os compromissos dos governos e outras entidades participantes. Dentre os compromissos, destaca-se o incentivo dado aos países para elaborarem seus Planos Decenais de Educação Para Todos, os quais deveriam contemplar as diretrizes e metas do Plano de Ação da Conferência Mundial.

Fundamentado no conhecimento coletivo e no compromisso dos participantes, o Plano de Ação foi concebido como uma referência e um guia 
para governos, organismos internacionais, instituições de cooperação bilateral, organizações não governamentais (ONGs), e todos aqueles comprometidos com a meta da educação para todos. (UNESCO, 1998, p. 5).

O Plano de Ação para satisfazer as necessidades básicas de aprendizagem, que consta da Declaração Mundial sobre a Educação para Todos, destaca dentre outros elementos o artigo $7^{\circ}$ que trata sobre o fortalecimento das alianças entre as autoridades responsáveis pela educação, as quais têm a obrigação de proporcionar educação básica para todos os municípios. Reconhecendo que não poderão suprir tudo, propõe que trabalhem em conjunto, que façam "articulações e parcerias", o que implica possibilidades dos regimes de colaboração.

Não só a participação dos governos, mas outras participações da sociedade civil, pública e privada são importantes para se alcançar as metas de educação para todos, como declarado no item sobre os princípios e ações do referido documento, em que há o reconhecimento da responsabilidade de toda a sociedade.

Nessa direção, o documento propõe que todos os profissionais envolvidos com a escola também sejam responsáveis para promover uma educação de qualidade e por isso, faz-se necessário proporcionar a "capacitação especializada" desses profissionais a fim de "preparálos para o exercício de suas funções". O documento assim deixa claro que alguns países terão que desenvolver mecanismos de "planejamento e gestão, aos níveis estadual e local, com uma maior distribuição de responsabilidades" e também desenvolver "programas de formação e de capacitação em serviço para o pessoal-chave”. (UNESCO, 1998, p.9).

Associado aos novos modelos de gestão e administração possíveis por meio da participação de todos na educação, destaca-se também o papel e a influência que as modernas tecnologias de comunicação e informação podem ter para ajudar a melhorar a gestão da educação básica e, nesse sentido, o documento do Plano de Ação também enfatiza que, além de uma boa seleção de tecnologias, é importante cuidar para que os profissionais saibam utilizá-las nas escolas.

Esses elementos são apresentados como fundamentais juntamente com o reconhecimento sobre o papel e a situação social dos atores da educação, entre eles os professores e administradores, os quais têm ação decisiva para que a "educação para todos" ocorra. É importante ressaltar novamente que no documento há o reconhecimento e a preocupação com a formação desses profissionais reforçando as orientações para que os países considerem esse aspecto em suas ações reformistas, atentando-se para as orientações de criação de programas de formação em serviço e na modalidade a distância. 
Retomando os documentos do Banco Mundial nesse movimento de compreensão histórica sobre as diretrizes e orientações dos OIs, considerando os anos de 1990 e as consequências dessa Conferência Internacional em Jontien, o BM disponibiliza o documento intitulado de "Pryoridades y Strategias para La Educación" em 1996, como destacamos no tópico anterior.

Esse documento, numa perspectiva de Política Oficialmente Declarada - POD, inicia sua apresentação por meio de uma linguagem discursiva, apontando que suas ações vêm ajudando a melhorar a educação mundial, mas reconhecendo também que tem muitos desafios a serem vencidos e, por isso, insiste para que os sistemas educacionais e seus países adotem suas orientações.

Dentre os desafios destacados no diagnóstico desse documento, é enfatizada a questão do acesso, da melhoria e equidade, a elevação da qualidade e o aceleramento do ritmo das reformas de educação nos países em desenvolvimento. Sobre o desafio relacionado ao acesso à educação, o documento ressalta o problema do analfabetismo em alguns países, apresentando uma expectativa de que mais de 162 milhões de crianças, na fase de alfabetização até os 11 anos, ficariam sem ter acesso ao ensino primário até o ano de 2015, se alguma coisa urgente não fosse feita. Apresenta também a preocupação com os problemas de acesso de alunos da educação secundária e superior, tendo em vista que o quantitativo de estudantes será bem maior que o número de vagas destinadas.

Com relação à melhoria da equidade, o documento aponta os problemas de desigualdades econômicas entre grupos em desvantagens que não podem dar escolas de qualidade para seus filhos, considera também a questão de gênero, em que, em alguns países, o acesso escolar entre homens e mulheres é desigual o que afeta a geração adulta.

Também considera a falta de equidade com os gastos públicos com a educação superior, nível que atende aos discursos do BM, a uma classe favorecida, enquanto seus gastos poderiam ser mais bem distribuídos para os outros níveis educacionais. A respeito do problema da qualidade educacional, o documento afirma que ele se refere mais aos países em desenvolvimento cuja educação é deficiente em quase todos os níveis, comparado aos países desenvolvidos.

Em relação à aceleração das reformas, as declarações desse documento sobre "Pryoridades y Strategias para la Educación" de 1996, recaem no fato de que muitos países, até aquele momento, que não haviam iniciado as reformas necessárias na educação e, por isso, estavam dificultando que as mudanças na educação ocorressem e, consequentemente, não 
estavam contribuindo para reduzir seus índices de pobreza, o que atrasava o desenvolvimento econômico do país, considerando a evolução dos países desenvolvidos, sobretudo aqueles que estão investindo em capital humano.

O diagnóstico do Banco, apresentado no documento em questão, enfatiza que os sistemas educacionais, por meio de sua administração e financiamento da educação pública, não estão preparados para vencer tais desafios e, portanto, reafirma que ele (o documento) se representa como um norte para auxiliar os países em suas ações, sobretudo a partir das necessárias reformas educativas.

A partir de suas orientações para as reformas, enfatiza-se que elas devem levar em conta pelo menos cinco prioridades, que estão associadas aos desafios apontados, como dar mais prioridades à educação considerando suas múltiplas funções e potencialidades para o desenvolvimento econômico do país; prestar atenção nos resultados da educação por meio de avaliações da aprendizagem e de análises econômicas; realizar a inversão da educação básica (níveis primário e secundário) para que se torne o centro das políticas públicas, deixando a educação superior para ser financiada pela própria sociedade que dela se beneficia.

Outra prioridade é relacionada ao fato de que a equidade pode ser resolvida de modo a garantir formas mais justas de ingresso à educação, desde que os candidatos demonstrem condições para obter a vaga pleiteada. Essa prioridade também implica melhorar as formas de gestão e financiamento dos recursos públicos, uma vez que passa a ser possível a oferta de bolsas para assegurar que todos tenham acesso à educação. Além da preocupação com os pobres e marginalizados, o Banco também é enfático ao preocupar-se com o acesso das mulheres à educação.

Há um enfoque para que os países proponham em suas reformas mais incentivo e acesso das mulheres à educação, pois elas também são percebidas como um importante e necessário capital humano. $\mathrm{O}$ documento declara que a mulher que se educa mais pode diminuir o número de filhos, o número de óbitos e que elas são as maiores incentivadoras para que seus filhos também estudem. "La educación influye em la fecundidad a través del aumento de la edad a que las mujeres contraen matrimonio y del mayor uso de anticonceptivos”. (BM, 1996, p. 52).

Há ainda outra importante prioridade para as reformas, de acordo com esse documento do BM, que está relacionada à questão das parcerias e relacionamentos dos pais com a gestão da escola, que não é novidade nesse documento, conforme já anunciamos anteriormente. Por fim, tem-se também a prioridade relacionada à autonomia administrativa e financeira das 
instituições, pela qual o documento reconhece as potencialidades de melhora da qualidade educacional.

Com relação aos argumentos e orientações que tratam sobre a formação de professores, percebe-se a ênfase para o desenvolvimento das reformas educacionais de forma que a educação possa alcançar os objetivos de formar indivíduos preparados e competentes para o mercado de trabalho. No referido documento de 1996, a ênfase continua sendo dada à formação continuada em serviço para os docentes, a qual é entendida como uma possibilidade de que esses profissionais tenham bom conhecimento sobre o assunto da área e às práticas da sala de aula.

La capacitación em el servicio para mejorar el conocimiento de las asignaturas por parte de los maestros y las prácticas pedagógicas conexas es especialmente eficaz cuando está directamente vinculada a la práctica em el aula y es impartida por el jefe de docentes. (BM, 1996, p.28).

Há o reconhecimento da importância e necessidade da formação de profissionais da educação e, por isso, a colocam também como questão central para as reformas educacionais. Em relação ao sentido da Política Oficialmente Declarada - POD, o Banco Mundial enfatiza a formação docente reconhecendo sua importância e necessidade de formação de profissionais competentes, qualificados e flexíveis, considerando o modelo flexível de produção do capitalismo na atualidade.

No entanto, no sentido da Política de Fato - POF, ela prioriza uma formação em que o conhecimento das técnicas e os mecanismos de ensino se apresentam em detrimento do conteúdo pedagógico, além de diminuir custos com a contratação de professores e aumentar o quantitativo de alunos, focaliza também um discurso que enfatiza a teoria do capital humano a partir da formação em serviço.

La educación aumenta la produtividade em el mercado y em el hogar pues permite adquirir más informaciones; la educación mehora la capacidade de aprender. Pero para cosecharlos benefícios de las inversiones en educaciones es preciso ampliar as possibilidades de aprendizaje productivo mediante inovaciones técnicas. [...] mejorar el aprendizaje, aumentando el coeficiente profesor-estudiantes. Utilizan menos maestros y poderíanas gnarlos recursos a otros insumos que mejoran el rendimento, como los libros de textos y la formacion em servicio. (BM, 1996, p.48 e 84).

Esses e outros elementos também estão presentes em outros documentos do BM e também em documentos da UNESCO, entre eles: Assistance strategies reduce poverty (1992); Prioridades y estrategias para la educación - estudo sectorial del Banco Mundial 
(1995); La enseñanza superior: las lecciones derivadas de la experiência (1995); Higher education in developing countries; periland promise (2000); Política para el cambio y el desarollo em la educación superior (1996); Educação: um tesouro a descobrir (1996); Declaração mundial sobre educação superior no século XXI: visão e ação (1998), dentre outros. (VIEIRA, MORAES, 2014).

Por sua vez, esses documentos também destacam que a formação dos profissionais da educação por meio da formação continuada em serviço tem maiores possibilidades se forem utilizadas as potencialidades da educação a distância $(\mathrm{EaD})$, conforme o próprio documento de 1996 "Pryoridades y Strategias para la Educacion" destaca: "los programas de educación a distancia para formación pedagógica em elservicio suelen ser más eficaces em función de los costos que los programas de enzeñasas em internatos”. (p.112).

A educação a distância é apontada nos documentos "oficiais e oficiosos" (EVANGELISTA, 2012) dos OIs, como um mecanismo que pode auxiliar o processo formativo dos indivíduos, como também se percebe em outro documento de 1995 do BM, "La enseñaza superior: las lecciones derivadas de la experiencia". Nesse documento, a EaD é reafirmada como um elemento central das políticas do BM para atender de forma mais eficiente às demandas de formação garantindo acesso de educação às camadas mais desprestigiadas.

Nesse sentindo, os documentos declaram oficialmente uma visão que é aparente, pois é uma visão invertida, quando se percebe de fato que eles não têm o interesse de propor soluções para os problemas reais dos sistemas de educação específicos de cada país.

Mesmo que haja o reconhecimento pela educação em seu papel amplo e diversificado, as orientações internacionais demonstram uma preocupação baseada nos interesses educacionais que se voltam para os resultados assumidos com a elevação da produção econômica. Por isso, a formação dos profissionais e a ressignificação dos modelos de gestão se fazem necessários, mas não na perspectiva da preparação de indivíduos emancipados enquanto sujeitos de sua história e de seu tempo.

Quando os documentos enfatizam que todos devem ter direito de acesso aos conteúdos mínimos, deseja-se oferecer conhecimentos básicos e necessários para se obter profissionais com competências específicas e adequadas às vagas de emprego e que possam aumentar os rendimentos econômicos, diminuindo, assim, uma parte da pobreza global, mas não uma diminuição total, como ressalta Silva (2000). Daí o surgimento de programas assistencialistas e de caráter compensatório. 
Com relação à pobreza os gestores do Banco Mundial não se interessam por todo o empobrecimento da população. [...] o interesse concentrou-se, apenas $10 \%$ da população desprovida de uma cesta básica, tendo como estratégia para mitigar a pobreza indigente, os programas focalizados concebidos dentro da lógica assistencialista. Quanto às necessidades básicas de aprendizagem [...] o Banco Mundial propôs políticas para alcançar as necessidades básicas de aprendizagem para todos [...] Na sua concepção prevaleceu a lógica credencialista-utilitarista, a ênfase dessa política foi direcionada à metodologia de ensino, ou seja, como ocorre a aprendizagem e como se pode expandir os conteúdos mínimos, mais do que como transmitilos, com o propósito de que aqueles que têm acesso à escola pública adquiriram conhecimentos, competência, domínio de linguagens, habilidades, destrezas essenciais para o aliviamento da pobreza e produzam maiores rendimentos econômicos. (BRACHO, 1992, apud SILVA, 2000).

A educação está diretamente ligada aos interesses declarados pela teoria do capital humano, na qual importa que os indivíduos, considerados como recursos humanos, qualifiquem-se, obtenham competências técnicas e habilidades necessárias para desenvolver com presteza, eficiência e rapidez os exercícios de sua profissão.

Quando as políticas são materializadas por meio das reformas, como as evidenciadas no Brasil, sobretudo a partir do governo do presidente FHC, por sua vez, continuadas no governo de Lula e Dilma, percebemos muitas de suas dimensões contraditórias. Shiroma (2011), por exemplo, ressalta que os discursos neoliberais dos OIs tentam convencer que os problemas da falta de qualidade da educação estão relacionados à falta de "bons professores e escolas eficazes", portanto reafirmam que mais do que recursos financeiros, a educação precisa de bons gestores para gerir melhor os recursos já existentes.

A autora aponta que, no Brasil, as diretrizes para formação de professores receberam e recebem muitas críticas, sobretudo porque amplia "o leque de funções docentes atribuindo grande ênfase às atividades de gestão" (SHIROMA, 2011, p.6), dando centralidade nos documentos e políticas educacionais, ao mesmo tempo atribuindo funções adicionais e responsabilizando o professor pela qualidade e desempenho dos alunos.

Essa lógica se apresenta, por exemplo, na prioridade cinco do documento do BM, "Pryoridades y Strategias para la Educación" de 1996, quando é enfatizada a necessidade de se prestar atenção aos resultados das avaliações do desempenho dos alunos de acordo com as análises econômicas. Por sua vez, esse discurso de responsabilização também recai sobre os pais e responsáveis pelos filhos nas escolas, além das parcerias e regime de colaboração o que é muito enfatizada para ocorrer entre a sociedade e as instituições de educação. 
Como destacamos no documento do BM (1996), a prioridade que se refere ao mecanismo de participação dos pais na gestão da escola se apresenta bem contraditória, quando o discurso é o de melhorar a qualidade da educação e desenvolver mecanismos de uma gestão mais democrática. Entretanto, a participação está associada à responsabilização dos pais e comunidades pelo o acompanhamento dos recursos aplicados na educação.

La reforma también da buenos resultados cuando aumenta la participación de la comunidad, de los padres y de los alumnos. El control que ejercen la comunidad y los padres, cuando está acompañado de medidas orientadas agarantizar el suministro equitativo de recursos, puede compensar em gran parte el poder de los interesses creados, como los sindicatos de maestros y la elite. La participación de los padres y las comunidades se puede aumentar mediante la descentralización, la autonomía a nivel de la escuela y la responsabilidad de ésta ante la población local. (BM, 1996, p.178).

No mesmo sentido, esse documento também aponta que, quanto mais os pais e responsáveis participarem da administração escolar, mais podem estar dispostos a contribuir com o financiamento da educação dos filhos, o que certamente também estará ajudando a diminuir os gastos com a educação pública. De fato, o que se percebe não é o interesse de desenvolver práticas de gestão democrática e participativa na educação, mas sim descentralizar as responsabilidades de administração da escola.

Desde o documento da Declaração de Educação para Todos em Jontien (1990), por exemplo, vemos que ele se apresenta como uma possibilidade de os países se ajudarem e apoiar as ações nacionais e regionais para implementação dos Planos Nacionais de Educação:

Seis áreas parecem-nos particularmente apropriadas a essa forma de colaboração regional:

(i) capacitação de pessoal chave, como planejadores, administradores, formadores de educadores, pesquisadores, etc.;

(ii) esforços para melhorar a coleta e análise da informação;

(iii) pesquisa;

(iv) produção de material didático;

(v) utilização dos meios de comunicação para satisfazer as necessidades básicas de aprendizagem; e

(vi) gestão e uso dos serviços de educação a distância. (UNESCO, 1998, p. 11).

Nessa passagem, fica expressa uma compreensão a respeito do regime de colaboração dos OIs, o qual tem como foco as seguintes questões: capacitação, avaliação, produção de insumos materiais e uso de tecnologias, assim como o incentivo pela educação a distância.

Não há dúvidas de que a participação dos pais e da comunidade escolar seja fundamental para a construção do seu processo democrático, no entanto, como ressalta Paro 
(1992), não se trata de qualquer participação, pois existem condicionantes internos e externos que devem ser levados em consideração se a participação que se deseja seja a de contribuir para que a escola e a educação desenvolva sua função social e, para isso, os atores precisam ter consciência de seu papel como sujeitos ativos e a escola deve propiciar os meios e os fins para que essa participação ocorra.

Em relação ao suposto processo de colaboração, tão eminentemente ressaltado pelos documentos dos OIs, vemos que o sentido dado pelas Políticas Oficialmente Declaradas POD, são contrárias às Políticas de Fato - POF, pois o que é declarado como processo de colaboração entre os entes federados, entre países e até mesmo entre profissionais da educação não se aproxima das possibilidades da constituição de um Sistema Nacional de Educação e de um Plano Nacional de Educação, como defendido por Demerval Saviani e tantos outros educadores comprometidos com a educação no país, que entendem que o objetivo desse regime é o de proporcionar que a educação seja desenvolvida com os mesmos padrões de qualidade para todos.

$\mathrm{Na}$ construção do sistema nacional de educação e na efetivação do plano nacional de educação deve-se levar em conta o regime de colaboração entre a União, os estados, o Distrito Federal e os municípios, conforme disposto na Constituição Federal, efetuando uma repartição das responsabilidades entre os entes federativos, todos voltados para o mesmo objetivo de prover uma educação com o mesmo padrão de qualidade a toda a população. (SAVIANI, 2012, p.1).

A Constituição Federal de 1988 do Brasil, em seu artigo 211 estabelece que a "União, os Estados, o Distrito Federal e os Municípios organizarão em regime de colaboração seus sistemas de ensino". Essa nomenclatura "regime de colaboração" surge para abordar as devidas relações de parceria e compromissos entre os entes federados para a educação entendida como "direito de todos e dever do Estado e da família" e que por sua vez "será promovida e incentivada com a colaboração da sociedade, visando ao pleno desenvolvimento da pessoa, seu preparo para o exercício da cidadania e sua qualificação para o trabalho". (BRASIL, CF/1988, Art. 205).

Saviani (2009) destaca em entrevista ao Observatório de Educação que acredita que o regime de colaboração é importante e poderá ser materializado por meio de um Sistema Nacional de Educação, por meio do qual será possível atingir os objetivos fixados em lei, como a universalização do ensino fundamental, a erradicação do analfabetismo, o acesso à educação a todos como direito e condições de igualdade, dentre outros. Esse sistema 
coordenado pela União precisa ter a colaboração dos estados e municípios. Assim, Saviani também ressalta que:

[...] a educação deve ser encarada como problema de Estado, não de governo. Portanto, deve ter uma estrutura que não esteja sujeita à política de conjuntura, aos mandatos governamentais, porque educação deve ser pensada em médio e longo prazo. São necessárias estruturas permanentes que não sejam fortemente afetadas pelas conjunturas políticas e partidárias. (OBSERVATÓRIO DA EDUCAÇÃO, Entrevista Saviani, 2009).

Considerando esses apontamentos é possível perceber que o regime de colaboração, a educação para Todos e a educação de qualidade, eixos pretendidos pelos OIs focaliza outros interesses que não são os mesmos, como pontuados por Demerval Saviani e educadores comprometidos com a educação emancipatória.

De modo geral, os documentos dos OIs, desde seu nascedouro aos dias atuais propõem diretrizes como sendo a solução aos problemas e políticas educacionais, mas que, quando materializadas nas políticas dos governos, apresentam-se como "discricionáriascontencionalistas e antidemocráticas".

Silva (2000) ressalta que, para além dos discursos e justificativas baseadas em dados internacionais que não levam em consideração contextos nacionais e locais, ao invés de promover a inclusão, excluem; ao invés de valorizar os profissionais da educação, desvaloriza-o; ao invés de resolver e propor ações que de fato resolvam os problemas de analfabetismo, de pobreza e desigualdades sociais, mais as intensificam.

Tendo em vista que os documentos analisados do BM podem se referir a um período já distante, pois são documentos da década passada, poderíamos acreditar que suas diretrizes e orientações já não se fazem mais presentes, mas em termos históricos, essas análises se apresentam bem atuais, mudando-se apenas os discursos e a linguagem, mas mantendo-se o foco de que, numa primeira aparência, o fenômeno pode-se mostrar diferente.

Se tomarmos um documento mais recente do BM de 2011, "Estratégias 2020 para educação do grupo do BM", vemos, dentre outras questões, a atenção reafirmada para a melhoria da qualidade da educação e a aceleração da aprendizagem a partir de ações de melhoria na gestão dos sistemas educacionais por meio da proposição das reformas no sistema.

O documento é enfático ao afirmar que, para além de apenas inserir recursos na educação, é preciso "garantir que os recursos serão utilizados de forma mais eficaz, para 
acelerar a aprendizagem”. (p.5). Essa perspectiva já fora analisada por Shiroma (2011), conforme discutimos anteriormente a partir de outros documentos.

Outra continuidade presente nesse documento mais atual refere-se à questão da responsabilização para se ter bons resultados.

\begin{abstract}
A abordagem da nova estratégia ao sistema educacional centra-se em maior responsabilização e resultados como complemento de proporcionar recursos. Reforçar os sistemas educacionais significa alinhar a sua governação, a gestão de escolas e professores, regras de financiamento e mecanismos de incentivo, com o objetivo da aprendizagem para todos. Isto implica em reforma das relações de responsabilização entre vários atores e participantes no sistema educacional, para que esse relacionamento seja claro, coerente com as funções, medido, monitorizado e apoiado. Significa também estabelecer um ciclo claro de retorno entre financiamento (incluindo ajuda internacional) e os resultados. (BM, 2011, p.5-6). (grifos nossos).
\end{abstract}

O foco desse documento é a necessidade de se "investir cedo, investir com inteligência e investir em todos". Para alcançar essas premissas, o BM propõe como vias estratégicas a "reforma dos sistemas de educação no nível dos países e construir uma base de conhecimento de alta qualidade para reformas educacionais no nível global”. (Idem, p.9).

Em outro documento também recente de 2014 do BM, "Professores Excelentes: como melhorar a aprendizagem dos estudantes na América Latina e no Caribe", vemos, a partir de uma nova linguagem, princípios que se repetem. $\mathrm{O}$ documento apresenta evidências globais e regionais sobre a importância dos resultados da educação para o crescimento econômico e para a competitividade, mostrando números sobre as mudanças proporcionadas e reforçando o discurso sobre a importância do professor para a obtenção desses resultados na América Latina e no Caribe.

O documento é enfático ao considerar que há muito ainda o que deve ser feito para se chegar ao patamar dos países desenvolvidos, considerando, portanto, que será por meio das ações que fortalecem o desenvolvimento social a partir do maior número de capital humano. (BM, 2014). Assim, o documento focaliza três áreas para que ocorra a reforma das políticas de formação de professores, dentre elas a análise de políticas para recrutar melhores professores; programas para capacitar professores e desenvolver seu potencial para função docente e a revisão de estratégias para motivar o professor a dedicar o seu melhor para sua carreira.

O prefácio do documento reafirma que a qualidade da educação está diretamente associada ao trabalho docente e, portanto, apresenta-se como mais uma diretriz consensual a responsabilidade desse profissional para o sucesso da qualidade da educação. 
Com simplicidade elegante, este livro argumenta que a qualidade da educação está condicionada à qualidade de nossos professores. Propõe um novo enfoque com o recrutamento dos jovens mais talentosos para $o$ magistério, o aumento da eficácia dos professores em serviço e o provimento de incentivos que motivem os professores ao máximo esforço em todas as salas de aula, todos os dias, com todos os alunos. (BM, 2014, p.12).

Vemos assim, a continuidade das propostas internacionais do Banco Mundial, seja do século XX ou XXI. Nesse mesmo movimento histórico de declarações das intenções dos OIs, também é importante retomar as diretrizes da UNESCO, que como pontua Shiroma (2011), representa um organismo que "outorgou lugar de destaque à formação de recursos humanos na reforma da educação", recomendando entre outras questões:

Descentralização da gestão escolar educacional; autonomia da escola; participação de pais e professores na gestão escolar; fortalecimento do vínculo entre escola e comunidade; responsabilização da gestão dos profissionais da escola pela prestação de contas e assunção pelos profissionais escolares da competitividade e da lógica do mercado no interior da unidade escolar. Dedicou especial atenção às novas tarefas e ao currículo para profissionalizar e prover o docente com competências gerenciais, formando um professor-gestor. (SHIROMA, 2011, p.15).

Dentre os vários documentos publicizados e eventos organizados por esse organismo destaca-se, por exemplo, a Conferência de Nova Delhi, realizada em 1993, que contou com a participação do Brasil como um dos nove países signatários. Nessa Conferência, reafirmam-se os compromissos assumidos em Jontien sobre a meta global de educação para todos, "de buscar com zelo e determinação as metas definidas" e atender às "necessidades básicas de aprendizagem de todos os nossos povos tornando universal a educação básica e ampliando as oportunidades de aprendizagem para crianças, jovens e adultos". (UNESCO, 1998, p.2).

No documento Declaração de Nova Delhi dessa Conferência, são apresentadas promessas de que até o ano de 2000, ou antes disso, iriam ser resolvidos muitos problemas educacionais, dentre eles:

3.4 melhoraremos a qualidade e relevância dos programas de educação básica através da intensificação de esforços para aperfeiçoar o "status", o treinamento e as condições de trabalho do magistério; melhorar os conteúdos educacionais e o material didático e implementar outras reformas necessárias aos nossos sistemas educacionais;

3.5 em todas as nossas ações, em nível nacional e em todos os níveis, atribuiremos a mais alta prioridade ao desenvolvimento humano, assegurando que uma parcela crescente dos recursos nacionais $\mathrm{e}$ comunitários seja canalizada à educação básica e melhoria do gerenciamento dos recursos educacionais agora disponiveis. (UNESCO, 1998, p.3). (grifos nossos). 
Seguindo os ideais da Conferência Jontien (1990) e a Declaração de Nova Delhi (1993), a UNESCO cria a Comissão Internacional sobre Educação para o século XXI sob a coordenação de Jaques Delors. Essa comissão reuniu estudiosos de vários países que, sob o lema "Educação para Todos", elaboraram e divulgaram em 1997 o "Relatório de Delors: Educação um Tesouro a Descobrir”.

No Brasil, importante lembrarmos que foi nesse período, no ano anterior, que ocorreu a aprovação da Lei de Diretrizes e Bases da Educação Nacional, Lei nº394/96. Também é marcado por um período em que as diretrizes de Jontien se fazem presentes desde o Plano Decenal de Educação para Todos (1994-2003), o qual foi elaborado a partir da Conferência de 1994, conforme destacamos anteriormente, sendo implementado por meio das ações do governo do presidente FHC (1994-2002).

Dessa forma, o Relatório Delors é recebido como grande prestígio pelos dirigentes, tendo em vista que estavam em curso as pretensões das reformas no país. De forma geral, Malanchen (2008) pontua que, nesse Relatório Delors, “a educação é colocada como a chave mágica para resolução de todos os problemas que se referem à justiça social, sendo capaz de favorecer o desenvolvimento humano e está apta a contribuir no alívio da pobreza mundial”. (p.184).

Já no prefácio do Relatório, encontramos palavras (discursos) de encorajamento para uma educação permanente por meio dos quatro pilares da educação (aprender a conhecer, aprender a fazer, aprender a viver juntos e aprender a ser), com a ênfase dada aos dirigentes da educação para que eles sejam encorajados a ter iniciativas para aperfeiçoar suas competências de gestão e conhecimentos técnicos, em especial no que se refere ao aspecto financeiro. Há também o encorajamento para que a sociedade (pais, mães e profissionais) participe das ações diretivas da escola.

O professor é colocado como agente de mudança, pois como ressalta o documento, eles têm um papel determinante para "formação de atitudes - positivas ou negativas - perante o estudo. Devem despertar a curiosidade, desenvolver a autonomia, estimular o rigor intelectual e criar as condições necessárias para o sucesso da educação formal e da educação permanente". (UNESCO, 1997, p.145).

No mesmo sentido, não podemos deixar de destacar que, nesse Relatório, também fica enfatizada a formação de professores por meio da educação a distância, inclusive pontua que as universidades devem se especializar na oferta de aprender a distância considerando o pilar da educação de que cada indivíduo deve aprender a conhecer. 
Todas as universidades deviam tornar-se "abertas" e oferecer a possibilidade de aprender a distância e em vários momentos da vida. A experiência do ensino a distância demonstrou que, no nível do ensino superior, uma dose sensata de utilização dos meios de comunicação social, de cursos por correspondência, de tecnologias de comunicação informatizadas e de contatos pessoais, pode ampliar as possibilidades oferecidas, a um custo relativamente baixo. Estas possibilidades devem incluir, ao mesmo tempo, a formação profissional e os ensinamentos de enriquecimento pessoal. Além disso, de acordo com a ideia segundo a qual cada um deve simultaneamente aprender e ensinar, a universidade deve apelar mais à colaboração de especialistas além dos professores de ensino superior: o trabalho de grupo, a cooperação com a comunidade circunvizinha, o trabalho de estudantes a serviço da comunidade, são alguns dos fatores a que podem enriquecer o papel cultural das instituições de ensino superior e como tal merecem ser encorajados. (UNESCO, 1997, p. 138).

Nesse sentido, o Relatório reconhece que a formação dos profissionais da educação é requisito fundamental para melhorar a qualidade da educação, pontuando que é preciso melhorar o "recrutamento, a formação, o estatuto social e as condições de trabalho dos professores". O Relatório enfatiza que os professores precisam ter as condições necessárias: “pois estes só poderão responder ao que deles se espera se possuírem os conhecimentos e as competências, as qualidades pessoais, as possibilidades profissionais e as motivações requeridas". (p.146).

No ano de 2000, outra importante reunião internacional realizada pela UNESCO em Dakar, no Senegal, foi o Fórum Mundial de Educação, em que os membros participantes ao fazer avaliação dos resultados dos compromissos estabelecidos após os anos de 1990, redefinem novos prazos para que os países alcancem as metas estabelecidas e também propõem novas metas para alcançarem a Educação para Todos. Dentre outras questões, destacam-se o foco dado para a gestão, a qual é declarada como sendo um princípio que deve ser desenvolvido de forma democrática e participativa, assim como também reforçam o reconhecimento sobre a valorização e a qualificação dos professores como dimensões essenciais para se alcançar a necessária qualidade educacional.

O documento síntese dessa reunião, já na sua apresentação destaca que o Marco de Ação de Dakar representa um momento oportuno para um repensar da política educacional dos países membros considerando as exigências que o século XXI apresenta e os desafios não alcançados no século anterior. No caso brasileiro, destaca-se a coincidência com a aprovação do Plano Nacional de Educação (2000-2010), fato considerado como "sintonia com as demandas de nossa época”. (UNESCO, 2001, p.4). 
A educação como um direito fundamental, como peça chave para o desenvolvimento sustentável e para promoção da paz é retomada como argumento central. Destaca-se o reconhecimento sobre os desafios e as oportunidades para maior incentivo à educação das mulheres e reforçam que as ações da educação fundamental devem garantir sua gratuidade e qualidade.

Afirmam que as famílias que não têm o direito de colocar seus filhos e filhas na educação fundamental estão sendo excluídas de seus direitos, considerando as potencialidades de uma época em globalização, em que estão sendo marginalizados aqueles potenciais que poderiam colaborar com o desenvolvimento econômico.

Ainda em relação à gestão escolar, percebemos a ênfase dada ao desenvolvimento dos "sistemas de administração e de gestão educacional que sejam participativos e capazes de dar respostas e de prestar contas", ou seja, há uma prioridade para que os sistemas sejam “controláveis" por meio de uma gestão eficiente. (UNESCO, 2001).

Dentre as metas estabelecidas destacam-se a de "desenvolver sistemas de direção e administração educacional, sensíveis, participativos e controláveis” (p.19). O documento resgata as experiências desenvolvidas na década anterior e aponta que, embora tenha havido avanços, ainda existem muitos desafios para melhorar a gestão nas escolas, as quais são muito autoritárias e centralizadoras.

Fazem proposições para que as práticas de gestão sejam mais descentralizadoras, reafirmando, portanto, que as reformas podem ajudar, sobretudo com o apoio das tecnologias de informação e comunicação para apoiar esses processos. Ainda nessa meta, fica evidente o desejo de se "proporcionar capacitação para dirigentes de escolas e demais funcionários da área da educação”. (UNESCO, 2001, p.20).

Nas estratégias propostas nesse documento da UNESCO, destacam-se a da elevação do "status, o moral e profissionalismo dos professores" (p.21), em que há o compromisso de se buscar ações que possam melhorar a autoestima e o profissionalismo docente. Apoiam-se na justificativa de que esse profissional é um ator fundamental para promover a educação de qualidade, seja nos espaços formais ou não formais, e por isso, devem ser respeitados, valorizados e ter o acesso à formação continuada, inclusive a distância. O documento também destaca que, além do profissional ter esses direitos, eles têm deveres como os de "aceitar as responsabilidades profissionais e serem responsáveis perante a sociedade e a comunidade" (UNESCO, 2001, p.22). 
Sobre esses compromissos, o Marco de Dakar (2001) esclarece que, ao se desenvolver as estratégias, é preciso ter o cuidado para se propor ações que vão garantir, por meio do novo papel docente, que os alunos serão preparados para as novas demandas globais. Existem grandes expectativas sobre a função múltipla dos professores, em especial, dá-se ênfase na função do professor/gestor, os quais são responsáveis pela gestão do processo de ensino e aprendizagem de modo que possam: "compreender a diversidade de estilos de aprendizagem e de desenvolvimento físico e intelectual dos estudantes e de criar ambientes de aprendizagem favoráveis e participativos". (p.22).

Em documento mais recente da UNESCO especificamente sobre as lideranças escolares, "El liderazgo escolar em América Latina y el Caribe: Un estado del arte com base em ocho sistemas escolares de la región", de 2014, muitas das diretrizes acima destacadas também se reapresentam.

Embora o documento aponte que a preocupação em torno da formação dos dirigentes escolares na América Latina é recente e que poucos são os estudos sobre esse assunto, as proposições se repetem. O Documento recorre aos dados do Programa Internacional de Avaliação de Estudantes (PISA) coordenado pela Organização para Cooperação e Desenvolvimento Econômico (OCDE) e também aos dados do Segundo Estudo Regional Comparativo e Explicativo (Serce) da Oficina Regional de Educação para América Latina e Caribe (Orealc), que se destacam entre as principais características dos diretores escolares.

O documento ressalta que, mesmo se apoiando em dados desses órgãos, os mesmos não disponibilizam elementos essenciais sobre as condições do trabalho e formação dos diretores das escolas e, portanto, se propõe como um documento de estudo que aprofunde essas questões a partir do estudo de oito sistemas escolares da região da América Latina, sendo sete países e um estado do Brasil, no caso o Ceará.

Entre os objetivos desse documento destaca-se:

El interes estuvo puesto no solo en la obtención de información sobre los directores mismos, sino que también, y de manera fundamental, en la indagación en las políticas que se han desarrollado respecto de la dirección escolar desde una perspectiva comparada - de manera de cotejar similitudes y diferencias existentes en la región. (UNESCO, 2014. p.8).

Em outro ponto o documento enfatiza que:

En su conjunto, la evidencia y el análisis entregado por la investigación constituye un nuevo insumo para el avance en el fortalecimiento de las situación del liderazgo directivo en la región, y asi mismo para la orientación de una agenda de investigación sobre este tema. (UNESCO, 2014. p.93) 
Embora o documento se refira aos diretores escolares, tomamos seus resultados e orientações dadas como elementos que servem para todos os profissionais que integram a equipe diretiva das escolas públicas. Em relação às orientações do documento, ressaltam-se as orientações dadas às autoridades para que elaborem políticas a fim de fomentar as lideranças das escolas em termos de status, condições de trabalho e salário, definição de suas funções.

Reforçam-se as orientações para que sejam fortalecidas as políticas de formação inicial e continuada, assim como possam ser redefinidas as funções e criação de novas formas de seleção e ingresso dos gestores ao cargo. No mesmo sentido, reforça-se que deve haver um contínuo processo de avaliação em torno do desempenho das funções dos gestores associadas também as possibilidades de permanência ou não aos cargos, entre outras orientações.

Diante das visões declaradas pelas Políticas Oficialmente Declaradas - POD, pela UNESCO desde a década de 1990, assim como pelos documentos do BM, conforme destacados, vemos que continuidades permanecem a partir de um referencial macro para formação dos profissionais da educação, as quais se alargam também para a gestão educacional, tendo em vista que os profissionais também são responsáveis por ações de administração que sejam mais eficientes e competentes.

Poderíamos nos reportar a vários outros documentos do BM e da UNESCO e de outros OIs, mas considerando os objetivos propostos, é possível compreender que, os que aqui foram tomados como referência, auxiliam bastante para a discussão do objeto de estudo da presente pesquisa.

Como observamos, os documentos apontam em uma visão macro, os interesses e percepções a respeito da educação, reconhecendo sua função, destacando as orientações para o processo de gestão escolar e para a formação de profissionais da educação, mas de forma específica, apresentam como diagnósticos os mesmos problemas e desafios e apontam as mesmas soluções, embora anunciem superação, continuam com seus interesses subordinados ao capital e ao desenvolvimento econômico antes de tudo.

Os OIs repetem discursos, reafirmam e os reformulam à medida que as demandas no tempo e na história assim exigem. Eles distorcem o papel social da educação, à proporção que atuam para consolidar consensos e disseminar suas recomendações, desenvolvidas a partir de diagnósticos, comparações com países desenvolvidos, falseando ou não considerando os problemas das realidades locais e regionais dos países não desenvolvidos, a partir das experiências internacionais. 
Essas visões são necessárias para manter a nova ordem do capitalismo, fortalecendo o crescimento econômico, mas que, por sua vez, também são fundamentos para o adestramento, ou como argumenta Gomide (2010) são "os novos requisitos para conformar, ética e politicamente, o cidadão brasileiro". (p.112).

Para essa autora, as orientações dos OIs apresentam um "pacote de medidas genéricas, em que reflete uma concepção generalista, que explora a família, a comunidade civil e os meios de comunicação de massa, visando proporcionar a educação básica". (p. 110). A visão de gestão escolar está associada à descentralização de tarefas e recursos financeiros, numa concepção gerencialista e organizacional, assim como a formação de profissionais da educação, cujo foco é o de obter profissionais com mais competência e eficiência em suas ações.

Gomide (2010) sinaliza, em relação à UNESCO, que é um OI que "encobre a dimensão privatista, precarizada e adaptativa do ser humano, necessária a uma política de conformação e manutenção da ordem instaurada em nossa sociedade" (p.118). Propõem ações sistêmicas que seriam capazes de preparar o profissional por meio de estratégias da formação continuada apoiado nas reformas educacionais, mas que, na verdade, tem levado o docente a se conformar e se responsabilizar por sua formação.

Estas orientações, ideologicamente recomendadas às políticas para a
formação de professores, foram concebidas num caráter sistêmico, ou seja,
na perspectiva de que não se podem mudar as políticas docentes se não se
mudam as políticas da escola, a gestão, os currículos e a administração do
sistema. Esta concepção induz à proação dos professores na resolução de
problemas da escola e na gestão democrática. Características como
competência, flexibilidade e eficiência são incorporados à sua formação, de
modo a adequar o trabalho docente às exigências profissionais advindas das
inovações tecnológicas. Da mesma forma, os professores têm sido
responsabilizados por sua própria formação, considerada como um
empreendimento individual, num movimento articulado ao sucesso das
reformas educacionais. A perspectiva humanista do currículo contribui para
determinar o perfil do professor que se adapta e se conforma, de maneira
flexível, às mudanças nos processos produtivos, resultante de estratégias de
formação continuada. (GOMIDE, 2010, p.118).

Corroborando essas análises, Bastos (2014) ressalta que nas Políticas Oficialmente Declaradas - POD, por meio da linguagem discursiva nos documentos oficiais, percebe-se continuidades a respeito das críticas feitas aos currículos escolares, considerados ou muito teóricos ou muito práticos, apontando que para haver mudanças seria necessário desenvolver reformas educacionais de forma a garantir maior flexibilidade nos currículos tendo em vista 
que o objetivo educacional é o de garantir sucesso para empregabilidade para amenizar a pobreza.

Nas análises de Shiroma (2011), essas questões também são evidenciadas, sendo que a autora aponta que, em relação à formação de profissionais da educação, os OIs intensificam os discursos em torno da formação para a gestão, como ela analisa a partir das proposições das DCNs do curso de Pedagogia, em que há ênfase para formação de um professor com amplas funções, com destaque para a de um professor como um gestor e não exatamente do professor/gestor, ou seja, o professor como objeto e não como sujeito de seu desenvolvimento profissional.

\begin{abstract}
Nossa hipótese é que a ênfase da gestão nas DCNs tem em vista a implantação de uma nova concepção de "sistema de formação docente" que ao associar formação e carreira, institui novas formas de regulação no campo educacional tais como dispositivos de acompanhamento e de responsabilização, nova estrutura de incentivos que atrelam financiamento à avaliação de desempenho, condiciona o salário, carreira e gratificação aos resultados alcançados. Essa concepção alargada de profissionalização anunciada nas DCNs está se efetivando por meio de processos articulados de gerenciamento de professores ao mesmo tempo em que produzem um tipo específico de professor. Nesta ótica, o professor gestor poderia ser compreendido como produto e produtor dessas novas formas de gestão educacional. [...] Contrariando o anúncio das DCNs que atribuem ao professor a responsabilidade de 'gerenciar seu desenvolvimento profissional', as medidas implantadas em nome da profissionalização docente tendem a produzir um professor como alvo da gestão, e não como um gestor. (SHIROMA, 2011, p.16-17).
\end{abstract}

Nesse sentido, a autora pontua a centralidade dos discursos dos OIs em torno da avaliação de resultados, da gratificação por desempenho e da formação por meio da educação a distância. Não são, portanto, novas recomendações, pois, como vimos, aparecem de diversas maneiras nos diferentes documentos dos OIs e são adotadas nos governos dos presidentes brasileiros a partir da década de 1990, sendo continuada nas ações dos atuais governos.

Retomando a perspectiva gramsciana, vemos que a hegemonia é uma maneira das classes subalternas expressarem consentimento à classe dominante, sendo que essa domina as consciências e reproduz ideologias que distorcem e falsificam a realidade, de modo a que os dominados vejam a opressão como um fenômeno natural, como argumenta Moraes (2003, p.115).

Por essa perspectiva, podemos apreender que a Política Oficialmente Declarada POD, a partir dos consensos da linguagem e discursos dos documentos dos OIs, deseja demarcar os rumos e suas diretrizes ideológicas para o desenvolvimento das reformas, a fim de que as políticas educacionais sigam o ritmo adotado pela globalização, pelas novas formas 
de produção econômica a partir da perspectiva da acumulação flexível, enquanto classe dominante.

Por um lado, representa uma aparência fenomênica que tem sido sustentada por meio de discursos e consensos e, por outro, tem sido materializada por meio das reformas educacionais no Brasil, representando as Políticas de Fato - POF, e que se apresentam em continuidades nas políticas públicas, independentemente das descontinuidades dos governos de diferentes partidos que, como ressalta Shiroma (2011), é explicada pela "racionalidade que orienta as políticas públicas de educação num Estado capitalista", em que prevalece a "lógica de formar para a sociabilidade demandada pelo capital com prioridades e itinerário formativo indicado pelos organismos multilaterais". (p.17).

\subsection{Reforma na Educação Brasileira a partir de Consensos Estabelecidos pelos OIs}

No movimento de compreensão sobre as múltiplas determinações que cercam o nosso objeto de estudo, focalizamos, nessa seção, a discussão acerca da reforma educacional em curso no Brasil, iniciada com a reforma gerencialista da administração pública no período de governo do presidente FHC. Para tanto, retomaremos os marcos e orientações feitos pelos OIs, as dimensões sobre o Estado brasileiro e suas redefinições e faremos um recorte de compreensão histórica considerando 20 anos do período entre os mandatos de presidentes da república, que datam dos anos de 1995 ao ano de 2015.

A compreensão sobre as reformas na educação brasileira perpassa a compreensão sobre a ressignificação do papel do Estado neoliberal em que, em contexto amplo, está associada ao entendimento das crises econômicas vivenciadas em todo o mundo e que, segundo Antunes (2003), refere-se às crises da estrutura capitalista, conforme discutimos no Capítulo I.

Após um longo período de acumulação do capital, o modelo produtivo fordista e o próprio Estado, na condição de Estado de Bem-Estar Social, entra em crise e, nesse contexto, delineia-se o novo processo de reestruturação do modo de produção por meio da acumulação flexível do capital, ao lado do avanço do ideário neoliberalista, que se apresenta como a saída às crises.

Essa lógica perpassa os discursos dos OIs que são adotados pelos governos em prol das reformas educacionais. No Brasil, destaca-se o período da presidência de Fernando Henrique Cardoso (FHC), em seus dois mandatos de 1995 a 1998 e de 1999 a 2002, em que 
se consolida o projeto neoliberal a partir do desenvolvimento de reformas na estrutura estatal pública visando garantir estratégias para que o país pudesse acompanhar os novos tempos e as exigências do capitalismo contemporâneo. A esse respeito, Silva Júnior (2002, p.49) argumenta que,

[...] com legitimidade política e eleitoral e em um clima de 'hiperpresidencialismo', o presidente transforma o Brasil no país das reformas e o submete, apesar de suas peculiaridades, ao figurino do capital, desenhado, agora, pelos organismos multilaterais, com especial destaque para o Banco Mundial.

O Estado é projetado a seguir novos rumos a partir de uma reforma gerencialista que se configura como um importante instrumento de difusão das mudanças e transformações requeridas pelo setor empresarial e mercadológico, mas que, na verdade, trata-se de uma ideologia de reafirmação de que, só pela reforma, o sistema público funcionaria com mais eficiência e eficácia. O discurso que se manifesta não é o de substituição do Estado pelo mercado, mas sim o de uma reforma nele, para que então ele se manifeste, regulando o mercado.

Dentre as justificativas para a reforma na base administrativa do Estado brasileiro, conforme discutimos, tem-se o discurso de que o Estado estava em crise, como anunciava os OIs sobre os movimentos das crises internacionais e econômicas, os quais apontavam que suas causas e consequências levaram os países a vivenciar uma crise de Estado, baseada na incompetência de gerir e administrar e, portanto, fazia-se necessário desenvolver uma nova administração que tivesse caráter gerencialista e fosse competente.

Esses ideais, portanto, para alcançarem êxito, deveriam ser desenvolvidos por meio de um tipo especial de contrato de gestão que se pautava, sobretudo, na perspectiva da flexibilização, da descentralização e da privatização. Em prosseguimento às iniciativas reformistas, foi criado o Ministério da Administração e Reforma do Estado (MARE), Ministério coordenado por Bresser Pereira que conduziu as ações reformistas a partir do Plano Diretor da Reforma do Aparelho do Estado (PDRAE) a partir de 1995.

Como mecanismo de divulgação dos ideais da reforma, organizaram-se seminários e publicações com o objetivo de mostrar para a sociedade as necessidades da reforma, reafirmando possibilidades de mudanças na forma de gestão da empresa pública, a qual era considerada burocrática e que continha marcas patrimonialistas. Justificavam-se os interesses de modernizá-la assim como as empresas de negócios, como afirma Bresser Pereira (2001), “Ao invés da velha administração pública burocrática, uma nova forma de administração, que 
tomou de empréstimo os imensos avanços por que passaram, no século $\mathrm{XX}$, as empresas de administração de negócios". (BRASIL, PDRAE, 1995, p.27).

Dentre os pressupostos da reforma, destaca-se a busca por uma nova administração com caráter gerencialista e que fosse centrada na obtenção de resultados, no atendimento dos interesses do cidadão e focalizasse o incentivo à criatividade, à inovação e à produtividade. Essas propostas, portanto, para alcançarem êxito, deveriam ser desenvolvidas por meio do contrato de gestão, que nos dizeres de Bresser Pereira (2001), referia-se a um "instrumento de controle dos gestores públicos". (p.28).

Dentre as propostas da reforma administrativa que tinham com objetivos tornar a gestão mais eficiente a partir de seu caráter gerencialista e centrada na obtenção dos resultados, era preciso considerar o contrato de gestão. Por sua vez, essas propostas deviam considerar a existência de quatro setores, entre eles o Núcleo Estratégico; as Atividades Exclusivas do Estado; a Produção de Bens e Serviços para o Mercado e também os Serviços não exclusivos ou competitivos, e para cada um dos setores deveria haver um tipo de propriedade e um tipo de administração específica.

Trata-se de pressupostos de caráter ideológicos da reforma, os quais permitiriam alocar os direitos sociais, das áreas da saúde, da educação e da cultura, no setor dos Serviços Não exclusivos ou competitivos que não deveriam ser exclusivos do Estado, mas também poderiam ser definidos pelos princípios do mercado.

No setor dos serviços não exclusivos do Estado, as atividades dedicadas à educação, [...] deveriam ser transformadas, segundo defensores da reforma, no tipo especial de entidade pública não estatal, ou organizações sociais, pois entendiam que elas facilitariam a parceria entre o Estado e a Sociedade. (SOUZA, 2007, p.42).

Por meio de ações dessa natureza e tantas outras, a reforma promoveria a ampliação do espaço privado e a consequente diminuição do espaço público no que se refere aos direitos democráticos e, ao mesmo tempo, fortaleceria o reconhecimento de um espaço que antes não pertencia necessariamente ao Estado, o dos Serviços Não exclusivos do Estado. (SILVA JÚNIOR. 2002).

Autores como Peroni e Caetano (2012) chamam atenção para o fato de que essas ações representam a consolidação do projeto neoliberal instruído a partir das recomendações dos OIs, no sentido da Política de Fato - POF, em que, na verdade, ocorre a minimização do papel do Estado para com as questões de ordem social, "estratégias de retirada do Estado do campo das políticas sociais, já que não foram consideradas atividades exclusivas do Estado e não 
pertenciam mais ao núcleo estratégico, descentralizando a sua execução para a sociedade". (p.62).

A educação, de forma geral, e a educação superior sofreram as reações dessas diretrizes. No caso da segunda, Cunha Antônio (2003) lembra que a reforma representa uma "revolução administrativa", com o objetivo de promover uma "administração mais racional dos recursos" tendo em vista aumentar as matrículas sem ter que aumentar as despesas. Para isso, as universidades deveriam ter uma "efetiva autonomia", por meio da qual condiciona o montante de verbas a partir dos resultados da avaliação de desempenho. (CUNHA ANTÔNIO, 2003, p. 39).

Corroborando essas premissas, Ferreira (2012) também aponta que a educação superior foi reconfigurada, sobretudo a partir da LDB 9394/96, pelas demandas do capital internacional e pelas recomendações dos OIs. A autora destaca as modificações para a educação superior dessa década.

[...] a existência de instituições de ensino superior públicas ou privadas, com variados graus de abrangência ou especialização (art. 45 da LDB); a distinção entre as IES públicas, IES privadas sem fins lucrativo se IES privadas com fins lucrativos (Decreto $\mathrm{n}^{\circ} 2.306$, de 19 de agosto de 1997); a diversificação das IES, ao mudar sua organização acadêmica para universidades, centros universitários, faculdades integradas, faculdades, institutos superiores ou escolas superiores (art. $4^{\circ}$ do Decreto $n^{\circ} 2.306 / 1997$ ). Também o parágrafo único do art. 52 da LDB propiciou nova possibilidade de caracterização para as universidades: "É facultada a criação de universidades especializadas por campo do saber". Esse novo tipo de IES introduziu uma modificação substantiva em relação à natureza e à identidade das universidades tradicionais. (FERREIRA, 2012, p.459-560).

Considerando a formação de profissionais da educação, destacam-se nesse período de governo, ações da reforma educacional que buscaram por meio da educação a distância mecanismos de auxílio para a formação de professores em serviço. Assim, destaca-se como marco legal para a implantação da $\mathrm{EaD}$ a instituição da Secretaria de educação a distância (Seed) em 1996, a partir da qual foram desenvolvidos programas para atualização e formação de professores como: a TV Escola em 1996, o Programa Nacional de Informática na Educação (ProInfo) em 1997, o Programa de Formação de Professores em Exercício (Proformação) em 1999 e o Programa de Capacitação a Distância para Gestores Escolares (PROGESTÃO) em 2001, entre outros voltados para a formação, aperfeiçoamento e valorização de professores e gestores escolares, por meio de iniciativas com a EaD. 
A partir dessas e outras ações do governo de Luiz Inácio Lula da Silva (2003 - 2010), há um novo tipo de educação? Estudiosos desse período político do país, como Pinto (2006), reconhecem que em relação ao governo de FHC, o governo Lula se diferenciava por ser um governo que se relacionava mais e chamava a sociedade para participação, mostrando-se mais democrático, mesmo que essa democracia tenha sido marcada por uma característica formal e restritiva. De fato, o que o presidente fez em seus mandatos foi bem contraditório ao que prometia e ao que defendia durante as lutas como membro do Partido dos Trabalhadores. (PINTO, 2006).

Esse autor destaca que o governo Lula também dá continuidade às políticas assistencialistas e compensatórias na medida em que emprega o discurso da inclusão social privilegiando uma relação de "clientelismos entre o governo e setores desorganizados da massa trabalhadora", enquanto que para a classe mais organizada, promove políticas de “atrelamento e subordinação". (p.12). A educação tem uma perspectiva de moeda de troca:

Segundo o presidente, seu governo tem como prioridade a educação, e quando se garante a criança na escola estão-se garantindo menos adultos na cadeia. A tese é positiva, mas o que se verifica não é o direito a estudar, e sim, a criação de uma moeda de troca: estudo por um "trocadinho" ao fim do mês. Deparamo-nos com a exploração da miséria, pois, para quem não tinha nada, receber no final do mês $\mathrm{R} \$ 45,00$ é de grande valor. Assim, o presidente, torna-se, aos olhos do povo um bem-aventurado. (PINTO, 2006, p.12).

A educação superior foi palco de reformas profundas, as quais têm como base os mesmos discursos instaurados no governo de FHC de que o Estado ainda enfrentava crises e, por isso, demandava reformas, mas as crises são a aquelas próprias do capitalismo e, portanto, a reformulação também estava conectada às políticas difundidas pelos intelectuais internacionais.

Dentre as ações da reforma educacional do governo Lula, é possível situar: o Programa Universidade para Todos (ProUni); o Sistema Nacional de Avaliação (Sinaes); a Lei de Inovação Tecnológica; o Projeto de Lei que institui o Sistema Especial de Reserva de Vagas; os projetos de lei que tratam da reformulação da educação profissional e tecnológica; a Gratificação de Estímulo à Docência (GED); apoio a criação das Fundações de apoio privado no interior das universidades.

Destaca-se também o Decreto Presidencial de 2005, que normatizou a educação a distância, fortalecendo a abertura do mercado educacional ao capital estrangeiro; o Decreto de 2007, que instituiu o Programa de Apoio a Planos de Reestruturação e Expansão das 
Universidades Federais (Reuni); o Programa Expandir as Universidades Federais; a criação do Plano de Desenvolvimento da Educação (PDE), dentre outros. (LIMA, 2006, FERREIRA, 2012).

Dentre as ações que envolvem os programas de formação para profissionais da educação, além da continuidade das ações da Seed do governo FHC, destacam-se: a criação do Programa de Formação Inicial para Professores em Exercício na Educação Infantil (ProInfantil) em 2005; O Programa Nacional Escola de Gestores da Educação Básica Pública em 2004/2009; o Programa Mídias na Educação em 2005; o Programa Universidade Aberta (UAB) em 2006.

Destacam-se ainda o Programa de Formação Continuada de Professores para a Educação Especial em 2007; o Programa Nacional de Formação Continuada em Tecnologia Educacional (ProInfo Integrado) em 2007; a Rede UAB de educação para a diversidade em 2008; o Plano Nacional de Formação de Professores da Educação Básica (Parfor) em 2009, dentre outros programas, cujos objetivos também estão associados ao apoio para a formação dos profissionais da educação. Contudo, nesse governo, o foco se direciona para a inclusão social e formação inicial e continuada, por meio da EaD.

Nos mandatos da presidente Dilma Rousseff (2011 a 2015), essas marcas governamentais continuam, no entanto, sob novas roupagens, como destacamos de Peroni e Caetano (2012). Tendo em vista que o papel do Estado é minimizado para as políticas sociais e maximizado para as questões econômicas sendo que a responsabilidade de execução das políticas sociais é repassada para a sociedade, já que não são mais consideradas como atividades exclusivas do Estado e são, portanto, considerados parceiros importantes.

As marcas e continuidades das políticas neoliberais dos governos brasileiros, a partir dos anos de 1995, no Brasil, conforme pontuamos no Capítulo I, são reconhecidas por seus modelos alternativos, como o Novo Desenvolvimentismo sendo o desenvolvimentismo do capitalismo neoliberal, marcados exclusivamente pelas ações dos governos Lula e Dilma. (BOITO JÚNIOR, BERRINGER, 2013).

Essa perspectiva pode ser entendida a partir de Gramsci, quando ele postula suas ideias sobre o partido e o intelectual orgânico. Na luta hegemônica, os partidos políticos, integrantes da sociedade civil, são para Gramsci o organismo responsável pela reforma intelectual e moral, pois representam e dirigem a vontade coletiva. 
Costa (2016) pontua que, nessa perspectiva, o papel básico de um partido voltado para os interesses do operário, seria o de representar um elo entre os princípios que buscam a crise de hegemonia ou a contra-hegemonia e não o contrário.

O papel básico do partido operário é contribuir para a elevação da consciência da classe, superando os marcos dos interesses puramente imediatos, economicistas, corporativos, para o nível da visão global da realidade, forjando, desta feita, uma "vontade coletiva nacional - popular", capaz de hegemonizar um projeto político nacional de construção da sociedade socialista. O partido, portanto, é a organização capaz de promover a passagem do momento "egoísta-passional", economicista e corporativo dos grupos sociais para o momento ético-político, universalizante, hegemônico, no que Gramsci chama de momento "catártico", quando a ideologia, como criação da fantasia concreta", atua sobre um povo disperso e pulverizado para despertar e organizar a sua vontade coletiva. (COSTA, 2016, p.5).

No caso dos períodos de governos dos últimos 20 anos no Brasil, vemos que as reformas educacionais seguem os mesmos princípios e diretrizes dos governos de partidos que se põem contra a hegemonia estabelecida, mas que reproduzem ações hegemônicas que não apresentam rupturas com os modelos dominantes, como percebemos pelo governo de Lula, pautando-se em princípios de "inovação, empreendedorismo, competitividade, formação e atração de capital humano, mobilidade internacional, universidade como agente de desenvolvimento econômico e social". (FERREIRA, 2012, p.468).

Essas análises sobre os períodos de governos e as reformas na educação brasileira estão em acordo como o que Shiroma (2011) pontuou e que já destacamos anteriormente de que a continuidade das políticas segue uma mesma racionalidade, cuja lógica é a de formar para a "sociabilidade demandada pelo capital". (p.17).

\subsection{Síntese do Capítulo}

Mota Júnior e Maués (2014) argumentam que as diretrizes internacionais, no âmbito da gestão, se dão por meio das parcerias público-privadas, dos contratos de gestão e da descentralização, do financiamento com a manutenção dos padrões de financiamento como percentual do PIB em educação nas últimas duas décadas e da avaliação (entendida como instrumento de regulação e controle). Com esse tripé da nova regulação educacional, na América Latina e no Brasil, é possível identificar as principais transformações operadas na educação brasileira. 
Peroni e Caetano (2012) lembram que a lógica do quase mercado em que estão inseridas as atividades dos setores não exclusivos do Estado a partir da reforma gerencialista, a propriedade continua sendo estatal, mas é orientada pelo capital, justificando-se que o mercado é mais eficiente e produtivo do que o Estado e, por isso, as reformas são essenciais.

Diante das ressignificações no papel do Estado à luz do ideário neoliberalista, é perceptível que há diminuição, entre outras questões, dos direitos sociais que, diretamente, são observados pelas práticas de criação de políticas sociais que tenham interesses reais com uma educação de qualidade e que, a partir dos programas e políticas, sejam de fato ações eficazes, significando políticas compensatórias, típicas de um Estado neoliberalista.

É nessa perspectiva de atuação do Estado brasileiro que as políticas públicas são criadas e executadas, como é o caso do Programa Nacional Escola de Gestores da Educação Básica, nosso objeto de estudo nesta tese. Sobre a concepção e formação desse Programa como uma das ações das políticas públicas de formação para gestores escolares, vamos refletir com mais detalhes no Capítulo IV.

Tendo em vista que a educação a distância foi a modalidade de educação escolhida para que os cursos desse Programa fossem ofertados no Brasil, e ainda considerando que ela tem sido um elemento central das diretrizes internacionais para as reformas educacionais, passamos a discuti-la no próximo capítulo. 


\title{
CAPÍTULO III - EDUCAÇÃO A DISTÂNCIA E OS ORGANISMOS INTERNACIONAIS
}

\author{
O primeiro pressuposto de toda a existência \\ humana, e, portanto, também, de toda a história, a \\ saber, o pressuposto de que os homens têm de estar \\ em condições de viver para poderem fazer história.
}

Marx, Engels, 2009.

\subsection{Apontamentos Iniciais do Capítulo}

Neste capítulo, desenvolvemos uma compreensão sobre as características mais gerais sobre a modalidade da Educação a Distância de forma a apreender suas possibilidades, limites, bem como seus vínculos com os OIs, considerando que ela é a modalidade de educação escolhida pelo PNEGEB para a oferta dos cursos de formação continuada e de aperfeiçoamento aos gestores escolares do Brasil.

Essa compreensão é elaborada a partir de um estudo bibliográfico de pesquisas sobre cursos na modalidade a distância, sobretudo cursos para formação de profissionais da educação. Por um lado, destacamos argumentos favoráveis ao uso dessa modalidade para a educação, apontando possibilidades de uma formação na perspectiva da emancipação e transformação dos indivíduos.

Por outro, destacamos argumentos contrários à utilização da EaD como modalidade de educação, mostrando suas impossibilidades de se constituir em espaços de formação emancipatória, tendo em vista que a base de sustentação dessa metodologia está pautada na utopia da utilização das técnicas e tecnologias como instrumentos de inclusão social.

\subsection{Educação e Educação a Distância: Pressupostos Teórico-Conceituais}

Os significados para o termo da Educação a Distância (EaD) são variados, como destaca Belloni (2008), mas de forma geral as tendências apontam sobre a ênfase que esses significados têm em torno do processo de ensino e aprendizagem centrado na perspectiva da distância temporal, no uso de tecnologias da comunicação e informação (TIC), nos modelos 
on-line, na aprendizagem focalizada no aluno, além de estar diretamente ligada aos paradigmas da sociedade contemporânea e suas demandas para formação de profissionais.

Para além dos significados e concepções encontrados em torno do assunto, concordamos com Oliveira (2003) e Neder (2005) quando afirmam que Educação a Distância é, antes de tudo, "educação". Antes de pensarmos sobre a forma de organização de um projeto pedagógico a partir de suas modalidades, se presencial, semipresencial, modular, ou a distância, "é preciso pensar a respeito do significado que atribuímos à educação". (NEDER, 2005, p.78).

Nesse sentido, é preciso deixar claro que concebemos a educação como prática democrática, aquela em que por meio da prática social, há a apropriação do saber historicamente produzido pelos homens. Argumenta Paro (2002) que a educação "consiste na apropriação da cultura humana, entendida esta como aquilo que o homem produz em termos de conhecimentos, crenças, valores, arte, ciência, tecnologia, tudo enfim que constitui o produzir-se histórico do homem”. (p.16).

Educação como formação da personalidade humano-histórica do educando, pela apropriação da cultura em seu sentido pleno, que inclui conhecimentos, informações, valores, arte, tecnologia, crenças, filosofia, direito, costumes, tudo enfim que é produzido historicamente pelo homem e que, numa democracia, o cidadão deve ter o direito de acesso e apropriação. (PARO, 2011, p.696).

Em consonância com esse autor, os pressupostos de Gramsci (1982, 2004, 2016) e outros autores marxianos, como Frigotto (2001, 2009), Duarte (2008) e Saviani (2005, 2011a, 2011b) de que, a educação é uma atividade especificamente humana cuja origem coincide com a origem do próprio homem e, portanto, deve ser pensada e desenvolvida na perspectiva da emancipação humana e intelectual.

Gramsci (1982) já afirmava que "Na realidade, toda geração educa a nova geração, isto é, forma-a; a educação é uma luta contra os instintos ligados às funções biológicas elementares, uma luta contra a natureza, a fim de dominá-la e de criar o homem 'atual' à sua época”. (p.74).

Para compreender a educação se faz necessário compreender a essência e existência humana. Essa compreensão, por sua vez, perpassa a relação de educação com a concepção ontológica de trabalho na visão marxiana, tendo em vista que ele representa o ponto de partida da humanização dos indivíduos, é o pressuposto de toda existência humana. Nessa visão, o trabalho é também um princípio educativo. 
[...] para Gramsci, o processo de trabalho como princípio educativo é imprescindível na formação de novos intelectuais orgânicos para a classe trabalhadora que, organizada, concretize o ideal de uma sociedade emancipadora, onde tanto o trabalho material quanto o trabalho imaterial absorva uma visão crítica da realidade, uma visão coerente e unitária, que leve em conta a racionalidade, a totalidade e a historicidade das relações sociais. (NASCIMENTO, SBARDELLOTO, 2008, p.15).

Para fazer história os indivíduos precisam ter condições de vida, (MARX, ENGELS, 2009). Para se apropriar dos saberes historicamente produzidos, fazer educação, o homem precisa encontrar as condições essenciais para viver e, para tanto, transforma a natureza ajustando-a às suas necessidades, ou seja, realiza trabalho. Saviani (2005) lembra que "é pelo trabalho que os homens produzem a si mesmos. Logo o que o homem é, o é pelo trabalho". (p.225).

Como ponto de partida para humanização, Saviani (2007) ressalta que a relação "trabalho e educação" é uma questão de identidade, pois os homens aprendiam a trabalhar, trabalhando, na prática diária, no relacionamento com os outros, gerando e produzindo educação de geração a geração, como ocorria nas comunidades primitivas, em que não havia divisão de classes.

No entanto, esse sentido positivo educação ou ontológico de trabalho, não é fator dominante na sociedade moderna, pois os indivíduos não transformam a natureza pelas suas necessidades básicas de sobrevivência, não trabalham ou se educam para se formar e se produzirem como homens humanos, mas sim, pelas necessidades do capital, considerando as mudanças de interesse sobre o modo de produção do capital e as diferenças de classes em que vivem.

Na sociedade atual e moderna, a educação tem sido impressa pela dualidade entre teoria e prática e separação entre o que é manual e intelectual, mas como postulou Gramsci, essa dualidade deve ser combatida pela luta hegemônica, pela crise de hegemonia, para se alcançar a verdadeira revolução.

Gramsci teceu duras críticas ao modelo de educação da Itália de sua época em que já se previa reformas educacionais em que haveria um tipo de escola para formação profissional e outra para formação intelectual e humanista em geral, ressaltando as diferenças entre escola clássica e escola profissional, como bem pontuam Nascimento e Sbardelloto.

[...] a preocupação de Gramsci com a educação tinha relação com a sua crítica ao ensino técnico italiano de caráter pragmático, destinado aos trabalhadores - e estes destinados ao trabalho assalariado, à submissão e exploração pelo capital - e ao ensino humanista italiano, oferecido à 
burguesia - esta sim destinada a comandar, a dominar, a governar a sociedade capitalista, compondo os cargos na administração pública do Estado liberal-burguês. O processo de trabalho para Gramsci deve ser o princípio educativo, mas não o modelo de escola profissional de sua época (não diferente hoje) que apenas cumpria a função de eternizar as estratificações de classes e a pré-destinação da maioria ao trabalho alienante, sob falsos princípios democráticos. (NASCIMENTO, SBARDELLOTO, 2008, p.7).

Corroboramos com os autores marxianos que acreditam na educação a partir da perspectiva adotada pela teoria pedagogia histórico-crítica, em que educação e trabalho não podem ser pensados por essa via da relação de dualidade, e sim por meio de uma relação de unidade a partir de uma concepção de politecnia, como argumenta Saviani (1989):

A noção de politécnica se encaminha na direção da superação da dicotomia entre trabalho manual e trabalho intelectual, entre instrução profissional e instrução geral. [...] Ela postula que o processo de trabalho desenvolva, numa unidade indissolúvel, os aspectos manuais e intelectuais. Um pressuposto dessa concepção é de que não existe trabalho manual puro, e nem trabalho intelectual puro. Todo trabalho humano envolve a concomitância do exercício dos membros, das mãos, e do exercício mental, intelectual. (SAVIANI, 1989, p.9-10).

Frigotto (2009) também pontua:

A educação politécnica ou tecnológica e o trabalho como princípio educativo, nas poucas passagens da obra de Marx e Engels, não estão vinculados a dimensões especificamente dos projetos e métodos pedagógicos, e sim à concepção dos processos sociais e educativos, que de dentro do terreno contraditório e numa perspectiva antagônica às relações sociais capitalistas pudessem desenvolver as bases sociais, culturais e científicas das múltiplas dimensões do ser humano no horizonte da práxis revolucionária, para a transição a um novo modo de produção e organização da vida social. (p.5).

A partir dessas considerações iniciais sobre a concepção de educação e pressuposto de que a EaD é educação, acreditamos que ela precisa desenvolver-se pelos princípios da educação politécnica, como argumenta Moraes (2015) ao analisar a relação "Educação e Trabalho" diante dos modelos de EaD apresentados por Belloni. Moraes (2015) propõe um terceiro modelo a partir do que ela chama de "Modelo da Politecnia ou da Educação Omnilateral" (p.4), justificando sua proposta pela conexão com as ideias marxianas e contrahegemônicas de educação.

Essa proposta considera a necessidade de uma outra sociedade em que seja superado o dualismo teoria e prática, exige uma nova função social da escola a qual deva ser 
comprometida com a formação total dos indivíduos (formação omnilateral). Trata-se também de uma concepção de práxis, mais especificamente da prática social.

Numa concepção democrática de mundo, e sendo a educação direito de todos, ela deve contribuir para a construção do sujeito humano-histórico. É a maneira pela qual o homem se constrói em sua historicidade por meio do acesso à herança cultural historicamente produzida e necessária para sua transformação e para a transformação da hegemonia dominante.

Moraes e Pereira (2009) também ratificam essa questão ao conceberem a educação “como formadora do ser humano, para além da perspectiva de capacitação de 'recursos humanos', de modo a que [...] contribua para a emancipação humana como um dos requisitos para o exercício da cidadania". (p.65). Dessa forma, a "educação a distância compartilha dessas mesmas finalidades" (p.65).

Por sua vez, esses pressupostos estão de acordo com a proposta da escola unitária de Gramsci, cujo objetivo maior era com a perspectiva transformadora dos indivíduos a partir da formação de intelectuais que organizassem e formassem uma nova cultura de modo a construir uma contra-hegemonia à hegemonia dominante, como pontua Moraes (2003), que "é necessário que as consciências sejam libertas da hegemonia burguesa e criem uma nova cultura com novos valores, e consequentemente, uma nova ordem social”. (p.116).

Gramsci (1982), na obra "Os Intelectuais e a Organização da Cultura", refere-se à escola unitária como sendo um espaço de formação humana, intelectual e prática:

A escola unitária ou deformação humanista (entendido este termo,
"humanismo", em sentido amplo e não apenas em sentido tradicional) ou de
cultura geral deveria se propor a tarefa de inserir os jovens na atividade
social, depois de tê-los levado a um certo grau de maturidade e capacidade, à
criação intelectual e prática e a uma certa autonomia na orientação e na
iniciativa. $(p, 63)$.

Moraes (2003), ao basear-se nessas características e no princípio filosófico do diálogo de Paulo Freire, acredita que a EaD pode ser possível numa perspectiva crítico-emancipadora:

[...] a educação é concebida como prática da liberdade, a superação é possível e a interatividade e a potencialidade em EAD seriam dadas por relações sociais dialógicas entre os professores, os sujeito-aprendizes e o mundo mediante o uso livre e libertador da palavra, caracterizada pelo amor, pela reflexão e pela ação. Por isso, deveríamos abraçar os projetos políticopedagógicos, nos quais o uso da palavra seja valorizado e estimulado, em detrimento dos programas ou pacotes de treinamento para algum tipo de trabalho, em que o uso da palavra é restrito aos seus objetivos de eficiência e eficácia, na busca de uma maior competitividade e lucratividade. (MORAES, 2003, p.121). 
A nosso ver, os projetos para cursos na modalidade da educação a distância que tomam e vivenciam essas premissas e concepções, certamente buscarão utilizar meios e fins adequados para alcançar os objetivos de uma educação na perspectiva crítica e transformadora, priorizando a formação dos indivíduos na sua dimensão humana e certamente não contribuirão para execução de modelos massificantes de $\mathrm{EaD}$, reduzindo-se ao apelo vislumbrante das tecnologias e às necessidades do capital neoliberal.

De fato, evidenciamos que a $\mathrm{EaD}$ representa uma entre tantas políticas educacionais dos governos brasileiros, que tem sua presença mais intensificada a partir da expansão do uso das tecnologias. Ela vem sendo reafirmada como uma possibilidade para resolver problemas da educação, como o de expansão de vagas nas universidades e, sobretudo, para atender as demandas de formação de profissionais da educação.

No entanto, reconhecemos que, atualmente, com os grandes investimentos que o governo federal tem feito para a produção e execução de cursos a distância, existe mais a ocorrência de modismos tecnológicos do que necessariamente possibilidades comprometidas com a formação humana.

Várias pesquisas em torno dessa modalidade de educação têm apontando como resultados, seu uso para o barateamento da educação, para a formação em massa de trabalhadores marginalizados, em especial da área da educação e associado a esses elementos, o fato de que a $\mathrm{EaD}$ tem representado os interesses propalados pelos OIs em relação ao retorno econômico, conforme sinalizamos a partir da análise de documentos desses organismos.

\subsection{Educação a Distância: características e possibilidades}

Importante relembrar que a $\mathrm{EaD}$ não é um fenômeno recente no Brasil, considerando os modelos de cursos desenvolvidos por correspondência, rádio e televisão, no entanto é, a partir da década de 1990, que ela vem adquirindo relevância social como uma modalidade de educação reconhecida pela Lei 9394/96 e regulamentada por vários documentos legais, além de contar com as potencialidades das tecnologias como aliadas.

Sem pretender caminhar para os discursos modistas das tecnologias, não podemos ignorar suas características e potencialidades para a realização da educação, sobretudo da $\mathrm{EaD}$. Isso não significa dizer que estamos preocupados com uma formação de indivíduos que sejam competentes para o mercado de trabalho como tanto anseia o capitalismo, mas como 
anunciamos, preocupa-nos a formação de indivíduos humanos e históricos que aceitam o desafio de formação em cursos mediados por tecnologias.

Nesse sentido, concordamos com Oliveira (2003) ao apontar que:

[...] o que está em jogo é a criação de novas maneiras de (re) educar as pessoas, para lidar não exatamente com o aparato tecnológico, mas com as informações advindas desse novo tipo de saber ou propiciadas por ele. Esse contexto indica a necessidade de (re) pensar a educação, passando pelas formas de produzir, adquirir, transmitir e estocar o conhecimento, em que a formação se torne preponderante. Nessa formação deve ser incentivado o pensar e ativada a capacidade crítica, as quais, garantindo a produção do conhecimento, reafirmem as noções de ética e de solidariedade. (p.33-34).

Se por um lado se faz necessário estar atento aos reflexos do rápido avanço das tecnologias e seus impactos na educação, também é necessário aprender a utilizá-las a favor do processo de ensino e aprendizagem que emancipa, sem adotar uma postura de dependência, subordinação ou de recusa. Moraes e Pereira (2009) chamam atenção, pois, por mais que haja importantes possibilidades emancipadoras e democratizantes das tecnologias, há também "sérios riscos a considerar em relação à apropriação desses meios tecnológicos para fins mercantis e propagandísticos, que ferem os princípios éticos veiculando cursos massificados, de baixa qualidade, alienantes, impeditivos da formação profissional cidadã". (p.66).

A educação propiciada pela modalidade a distância, por ter características que lhes são peculiares, certamente precisa utilizar recursos das Tecnologias da Informação e Comunicação (TIC) como ferramentas que podem auxiliar o processo educacional. Isso ocorrerá, afirmamos novamente, na medida em que elas sejam apropriadas nos projetos dos cursos e seus usuários (gestores, professores e cursistas) passarem a utilizá-las numa perspectiva democratizante da produção de conhecimentos.

É importante que os projetos de cursos explicitem em suas propostas, e estas sejam executadas, por meio de metodologias em que o processo operacional das técnicas pedagógicas e dos processos de avaliação faça a mediação e o diálogo constante. Assim, a construção do material pedagógico, a gestão do curso, as possibilidade de convivência, as dinâmicas com o fator tempo e espaço, a realização dos encontros presenciais (quando houver), as parcerias do curso, dentre outras questões, estejam bem definidas e tenham clara a visão de homem que se deseja formar.

Fiorentini (2009), preocupada com as questões pedagógicas do "aprender e ensinar com tecnologias, a distância e/ou em ambiente virtual de aprendizagem" destaca algumas 
questões que considera importantes e que podem auxiliar o trabalho docente nos cursos a distância.

[...] espera-se que as decisões docentes promovam participação ativa, compartilhada e cooperativa; criem oportunidades variadas e flexíveis de negociação e construção de conhecimentos em ambientes presenciais e virtuais; utilizem um olhar prático-teórico aliado à força pedagógica da reflexão e observação da própria pratica docente; exercitem metacognição e empatia nas tentativas de compreensão das necessidades de aprendizagem, facilidades, dificuldades e de modos de superá-las. (FIORENTINI, 2009, p.137).

A partir das referências de Fiorentini (2009), Oliveira (2003), Ramos e Medeiros (2009), apresentamos algumas possibilidades para o desenvolvimento de cursos na modalidade a distancia. As autoras apresentam subsídios filosóficos e metodológicos sobre a construção e desenvolvimento de cursos em ambientes de ensino e aprendizagem on-line, especificamente para os de formação de professores a distância, ressaltando que de uma forma geral, é preciso uma ressignificação do conceito de aprender mediado por tecnologias.

Oliveira (2003) apresenta reflexões em torno das possibilidades e pertinência da EaD, especificamente para a formação continuada de professores. Ao discutir sobre a nova dinâmica social em que a educação se situa com o desenvolvimento e implantação de TICs, da necessidade de ressignificação das maneiras de aprender e ensinar e de reeducar os indivíduos, ressaltando que as "potencialidades pedagógicas das TICs, na mediação da EAD, têm como eixo a construção do saber a distância, modificando-se assim o paradigma que traz o conhecimento como estado e não como processo". (p.34-35).

Nessa perspectiva, a autora aponta pelo menos duas razões nas quais acredita na pertinência dessa modalidade de educação para a formação de profissionais da educação, destacando que:

Por um lado, visa atenuar as dificuldades que os formandos enfrentam para participar de programas de formação, em decorrência da extensão territorial e da densidade populacional do país e, por outro lado, atende ao direito de professores e alunos ao acesso e domínio dos recursos tecnológicos que marcam o mundo contemporâneo, oferecendo possibilidades e impondo novas exigências à formação do cidadão. (OLIVEIRA, 2003, p.40).

Essas razões, segundo a autora, estão associadas à perspectiva de formação críticoreflexiva e humanizadora dos indivíduos, pois ter oportunidade de formação, acesso e domínio de tecnologias, tem a ver com o direito do indivíduo e de ele contar com mais uma possibilidade de formação, mas que ela não que seja a única ou a melhor. Trata-se de mais uma possibilidade e espaço de formação, inicial ou continuada, em que os profissionais têm 
"para refletir na/sobre sua atuação, (re) elaborando seus saberes iniciais num movimento de circularidade" (OLIVEIRA, 2003, p.42), dados as características peculiares de aprendizagem a distância.

A autora argumenta que a mudança de paradigma é o "fio condutor da ruptura com o modo conservador/dominante de pensar e realizar a $\mathrm{EaD}$ e/ou qualquer modalidade de educação" (p.15). Dessa forma, tanto na modalidade presencial ou a distância, a formação de profissionais da educação deve ser pensada e executada buscando romper com os paradigmas conservadores e dominantes, pois se eles não mudarem "as possibilidades de rupturas e avanços tornam-se insignificantes, mesmo com a adoção de sofisticadas tecnologias digitais". (Idem, p.15).

Com relação ao fator "distância", destacado por muitos críticos da $\mathrm{EaD}$ como sendo o problema dos cursos nessa modalidade, Fiorentini (2009) reflete sobre a dicotomia em torno da questão da presença e da mediação tecnológica, uma vez que ela compreende que o fator distância não é problema apenas dos cursos na modalidade $\mathrm{EaD}$, pois em cursos presenciais, embora se tenha a presença física de docentes e alunos e todos se encontrem ao mesmo tempo e no mesmo espaço, pode haver até uma total distância entre eles. Dessa forma, a autora compreende que esse fator não é o único que poderia gerar dificuldades com a qualidade da educação.

Fiorentini (2009) reconhece que a distância em si não deve ser obstáculo, mas ela deve ser ressignificada. "Os relacionamentos, inclusive os pessoais, independem da proximidade no espaço e no tempo já que se viabilizam por distintos meios de informação e comunicação". (p.148). Dessa maneira, ela ressalta que, para aperfeiçoar a educação mediada por tecnologias, é necessário investir nos processos de colaboração, relacionamento e diálogo mútuo e para tanto se deve "equacionar adequadamente locais, horários, calendários, presença, distância, linguagens de comunicação e meios tecnológicos [...] por meio de um sistema de trocas contínuo com a sociedade e seu desenvolvimento humano [...]" (p.17).

Esse sistema de trocas e diálogos é importante para o aperfeiçoamento do fator interação/mediação em cursos nessa modalidade, sobretudo os virtuais, pois como ressalta essa autora, mesmo que os alunos tenham seus ritmos de aprendizagem e se organizem para realizar seus estudos no tempo cronológico que lhes convenha, eles sempre vão precisar do professor e de outros colegas na relação de ensino e aprendizagem, para melhor compreender os conteúdos, as atividades, as avaliações, a dinâmica do curso, para sanar dúvidas pedagógicas e técnicas quanto ao ambiente, enfim, embora estejam distantes no espaço físico, 
para que haja qualidade na educação, é essencial o aperfeiçoamento desse processo comunicacional.

É preciso buscar maneiras diferenciadas para virtualizar a discussão, o trabalho colaborativo e desenvolvimento de projetos, aprofundando o significado das interações e relações na solução de problemas concretos e reais, seja por meio de listas de discussão, fóruns, bate-papos, blogs, espaços colaborativos de trabalho no ambiente on-line. (PIPER, 2004, apud, FIORENTINI, 2009, p. 150).

Ramos e Medeiros (2009) também argumentam que o processo de construção de conhecimento nessa modalidade de educação ocorre de forma diferente quando são utilizadas as linguagens mediatizadas pelas tecnologias, no entanto, assim como na educação convencional, é preciso garantir que essas formas sejam significativas para professores e alunos, sendo aqueles considerados como mediadores e esses os agentes autônomos de sua aprendizagem.

Os canais de interação devem estar "contextualizados e as nossas inserções devem estar baseadas na certeza de que somos apenas mediadores de conhecimento, pois é o sujeito autônomo que irá utilizar de todo seu conhecimento prévio e do que disponibilizamos para construir sua aprendizagem". (p.49).

Nessa perspectiva, é esperado que docentes e alunos aprendam a se relacionar constantemente e de maneira significativa a partir da mediação pedagógica nos ambientes virtuais de aprendizagem, de forma a que, como destaca Fiorentini (2009), seja possível "superar a tradição verbalista na educação" (p.155), a partir da utilização de variadas estratégias comunicativas.

Trata-se, nesse sentido, do que Paro (2007) adverte sobre a função docente de propiciar condições adequadas para que o aluno queira aprender, e que aqui utilizamos para afirmar que na $\mathrm{EaD}$, o professor também precisa desenvolver meios adequados ao ensino mediado por tecnologias, de modo que possa auxiliar o aluno a querer aprender a distância.

Dessa forma, a mediação pedagógica em curso on-line certamente depende da utilização das mais variadas ferramentas tecnológicas para promoção da interação pedagógica, mas utilizadas de forma coerente para os fins utilizados. Assim, alunos e professores têm o desafio tanto do acesso a esses recursos, quanto também de saber utilizá-los na perspectiva da interatividade relacional. Oliveira (2003) argumenta que, em relação à formação de professores a distância, é preciso que a apropriação de tecnologias nos cursos possa 
possibilitar também a "formação de sujeitos construtores de conhecimento e pensadores de sua prática, num mundo de velozes mudanças e avanços tecnológicos”. (p.42).

No caso dos cursos que utilizam o ambiente virtual de aprendizagem (AVA) como o moodle, Ramos e Medeiros (2009) apresentam alguns elementos para a reflexão sobre sua utilização, considerando que ele oferece variadas possibilidades de interação, mediação, reflexão e aprendizado. Ressaltam que, na medida em que os usuários vão usando o AVA, explorando seus espaços e ferramentas de modo intuitivo e interativo, vão também aperfeiçoando esse uso: "Seguir intuições e navegar ao máximo no ambiente do curso são condições importantes para o domínio do ambiente moodle”. (56).

Ao iniciarmos a aprendizagem de uma nova ferramenta é natural sentirmos algumas dificuldades que tomarão mais tempo para o estudo do que o usual. $\mathrm{O}$ usuário do sistema irá perceber que na medida em que a interação e a navegação se tornar mais frequentes, ele passará a dominar o uso dos recursos e também a orientar seus olhares à aprendizagem e menos ao software. (MEDEIROS, RAMOS, 2009, p.56).

As autoras orientam que, ao se utilizar qualquer ambiente virtual, é preciso questionar sobre quais características desse software podem ser usadas de maneira mais efetiva para o processo de ensino e aprendizagem dos conteúdos. Além disso, é importante compreender como e quais tarefas on-line usar considerando o objetivo do curso, dentre elas os recursos de fóruns, questionários interativos, tarefas colaborativas, chat, bem como ter a percepção da melhor forma de disponibilização da interface dos módulos, temas, eixos dos conteúdos. “Lembramos que este ambiente será a sua sala de aula. Na sala de aula a forma de organizar o espaço expressa os princípios educativos, valores e crenças do professor". (p.58).

Ainda sobre o planejamento de cursos em AVAs, as autoras destacam a importância da organização de um plano de produção e os meios tendo em vista alcançarem os objetivos do curso. Nesse sentido, é fundamental ter claro qual a concepção de educação, ensino e aprendizagem para se decidir como será a forma de apresentação dos conteúdos curriculares, considerando que o AVA tem várias possibilidades de interfaces, além de se ter clareza de como irá organizar o tempo e espaço do ambiente.

Da mesma maneira, o material pedagógico deve ser elaborado numa linguagem envolvente e coerente com o objetivo da formação, assim como os textos principais e complementares, devem ser disponibilizados de modo a proporcionar um "estado de conversa virtual", ou seja, possibilitar a motivação para a interação e o diálogo nos espaços de debates. 
De acordo com essa ideia, Ramos e Medeiros (2009) destacam que os cursistas "diferem na maneira como têm acesso ao conhecimento em termos de interesses e estilos" (p.50) e, portanto, afirmam que o material didático e pedagógico de cursos on-line é um elemento muito importante e sua utilização deve estar articulada aos objetivos do curso e à construção de ambientes de aprendizagem virtual, para que de fato ocorra inclusão virtual ao invés da exclusão.

Com relação ao conteúdo, alguns questionamentos são importantes ao se planejar cursos na modalidade EaD. Ao considerar que cada conteúdo será apresentado a partir dos objetivos pedagógicos e serão utilizadas ferramentas tecnológicas diversas para promover o diálogo, as autoras ressaltam que é preciso questionar sobre quais objetivos de determinados conteúdos; observar se são sequenciais ou lineares; se coadunam como os conteúdos curriculares; quais as maneiras didáticas de apresentar tais conteúdos; como o processo de ensino e aprendizagem pode ser facilitado; quais os tipos de atividades deveriam ser desenvolvidos; quais atividades podem provocar o desenvolvimento da criatividade; que recursos materiais digitais (textos, hipertextos, imagens, som, vídeo...) são mais adequados e se são de fácil acesso; se os recursos exigem reflexão na ação; se propiciam a contextualização e descontextualização. (RAMOS, MEDEIROS, 2009).

Associado a essas questões, os cursos planejados para ambientes on-line, também precisam conceber e desenvolver processos de avaliação que considerem essas características de aprendizagem em processos e em dinâmicas que relacionam as interações com o conhecimento a partir dos recursos tecnológicos. Nesse sentido, Fiorentini (2009) chama a atenção para o fato de que esses recursos podem contribuir muito para a perspectiva da avaliação em processo, pois ao longo dos cursos é possível desenvolver vários registros sobre o percurso da aprendizagem.

No mesmo sentido, Ramos e Medeiros (2009) ressaltam que as metodologias de avaliação do processo de aprendizagem devem contemplar e instigar o "registro dos processos individuais e coletivos de aprendizagem, mediados pela tecnologia e orientados para fazê-lo docente e a identidade profissional em construção". (p.50).

Diante das reflexões apontadas, é possível compreender algumas características e possibilidades e também vislumbrar limites sobre a realização de cursos na modalidade a distância. Percebemos preocupações no sentido dos autores pontuarem elementos que devem ser pensados e repensados ao se elaborar propostas para formação de profissionais da educação por meio dessa modalidade de educação, de forma que essas propostas possam 
contribuir para que a formação se desenvolva na concepção emancipadora dos indivíduos que, por sua vez, contradiz as concepções de formação a distância propostas pelos organismos internacionais como melhor compreenderemos no próximo eixo deste capítulo.

É perceptível como a $\mathrm{EaD}$ interessa a muitos atores e instituições, considerando desde os educadores comprometidos com uma educação emancipadora, passando pelos alunos e profissionais que a veem como um direito, assim como as instituições privadas, aos empresários e os próprios OIs. Para uns existe possibilidades de se desenvolver educação a distância com qualidade e com seriedade, mas para outros, dado que o interesse maior é o econômico e financeiro, a EaD se torna uma alternativa viável de formação de mão de obra.

\subsection{Educação a Distância: Limites e Impossibilidades}

É senso comum afirmar que a modalidade de educação a distância revela-se como uma potencialidade nas políticas educacionais do Brasil, no entanto preocupam os estudos que apontam que, na forma como vem sendo desenvolvida no Brasil, tem representado uma forte estratégia dos Organismos Internacionais (OIs) para a mercantilização da educação, em especial a educação superior.

Essas características são demonstradas em estudos realizados por pesquisadores como Preti (1998); Borges (2002); Lima (2005); Oliveira (2009), Dourado (2011), Silva Júnior (2003, 2010), Otranto (2006), Santos (2008), Neves (2008), Souza, Silva Júnior, Floresta (2010), Gomes (2010), Nogueira (2011), Gomide (2010), Vieira e Moraes (2014), Malanchen (2008), Moraes (2015), dentre outros.

Partimos das reflexões propostas por Gomes (2010) a respeito da falta de clareza sobre a utilização da $\mathrm{EaD}$ no Brasil, e dos resultados de pesquisas dos autores que tratam sobre as políticas de formação de profissionais da educação por meio dessa modalidade para compreendermos algumas de suas características que se impõem mais como desafios do que como possibilidades.

Sabemos que no Brasil não há consenso suficientemente claro sobre a necessidade da $\mathrm{EaD}$ e sua finalidade no contexto educacional brasileiro. Oportunamente, com o advento das tecnologias de informação e comunicação (TIC), as práticas da EaD parecem cada vez mais recorrentes, com a justificativa da flexibilidade de acesso ao conhecimento e um número cada vez maior de pessoas. Mas, que tipo de saber essas pessoas estão acessando? Um saber que emancipa ou um saber que aliena e escraviza ainda mais? (GOMES, 2010, p.110). 
Preti (1998) ressalta que, diante a conjuntura de avanço das tecnologias e da sua introdução na educação, a educação a distância parece ser uma alternativa viável, tanto com relação às exigências sociais e pedagógicas quanto à questão de estruturação física como uma alternativa economicamente viável. "Ela passou a ocupar uma posição instrumental estratégica para satisfazer as amplas e diversificadas necessidades de qualificação [...] para a contenção de gastos nas áreas de serviços educacionais e, ao nível ideológico, traduz a crença de que o conhecimento está disponível a quem quiser”. (p.7).

$\mathrm{Na}$ pesquisa de Borges (2002), a autora destaca que a EaD tem sido assumida pelo Plano Nacional de Educação para Todos no Brasil como um elemento essencial no sistema educacional para atender às demandas de formação exigidas para o mercado de trabalho. Destaca que essa modalidade aparece como um "instrumento de democracia e emancipação" considerando suas possibilidades de alcançar alunos em todos os lugares, tempo e espaço. No entanto, ela chama atenção para um debate mais aprofundado para se apreender seus reais sentidos.

Quando o debate a respeito da emergência da educação a distância nos dias atuais é aprofundado, suas nuances são desnudadas, fazendo aflorar os interesses corporativos e as demandas econômicas que têm movido a maioria dos interesses da própria população, que, na maioria dos cursos de educação a distância, não tem sequer direito à voz, sendo condenada a dialogar consigo mesma ou com fontes virtuais de informações. Além disso, a maioria dos programas de educação a distância está buscando sua consolidação em práticas excludentes e antidialógicas, pois estão imersos em uma estrutura maior, cujas prioridades centram-se na utilização de meios tecnológicos, em detrimento das mediações existentes no processo de ensino-aprendizagem, de modo que as tendências da área educacional, incluindo os modelos de educação a distância, têm cumprido a pauta da agenda neoliberal, acompanhando as mudanças ocasionadas pela reestruturação produtiva em curso no país. (BORGES, 2002, p.99).

As pesquisas que relacionam o tema das políticas públicas para a formação de profissionais da educação por meio da educação a distância, consideram o processo de expansão da educação superior, no qual a $\mathrm{EaD}$ representa uma das respostas dadas pelo movimento reformista educacional que se fortalece, sobretudo, a partir dos anos de 1990 no Brasil, no contexto da influência das políticas neoliberais, conforme discutimos no Capítulo II.

Corroboramos com essa premissa de compreensão das políticas de formação por meio da $\mathrm{EaD}$ que a situa no contexto mais amplo de formulação e desenvolvimento das políticas públicas educacionais no Brasil, bem como no contexto das transformações estruturais 
vivenciadas no processo de ressignificação do papel do Estado diante do modelo capitalista vigente, o qual por sua vez, recebe influências de OIs que lhes imprimem diretrizes exigindo mudanças na função e na estrutura rígida e burocrática do Estado, visando à sua modernização para que, assim, ele possa dar respostas ao modo de produção capitalista.

Como discutimos, os OIs produzem discursos e consensos internacionais de modo a que os países realizem reformas administrativas e educacionais, tendo em vista proporcionar elementos que são considerados necessários para que a educação possa garantir a formação de mão de obra qualificada para atender às novas demandas de produção capitalista, que requerem um novo modelo de ser humano, adaptável, flexível e competente.

Gomide (2010) argumenta que essas demandas exigem características de "flexibilidade, competitividade, excelência, desempenho, eficiência, autonomia e equidade" (p.109), as quais conseguiram atender às necessidades do mercado de trabalho conforme proposto pelo projeto neoliberal de educação.

$\mathrm{Na}$ verdade, esse momento renovador fez parte de um [...] projeto neoliberal de educação [...] que acatava a intervenção de organismos multilaterais como a [...] (UNESCO), o Banco Mundial e [...] (CEPAL). Estes disseminaram um conjunto de ideias, orientações e recomendações essenciais para renovar o sistema educativo público e fazer o país ascender à economia de primeiro mundo. (GOMIDE, 2010, p.110).

Como evidenciamos, vários documentos dos OIs, em especial do Banco Mundial e da UNESCO, destacam as potencialidades de formação para os profissionais da educação por meio da $\mathrm{EaD}$, considerando os aspectos da diversificação das instituições e acesso à educação superior. Um exemplo é do documento do BM "La enseñaza superior: las lecciones derivadas de la experiencia" de 1995, que aponta a EaD como um elemento central de suas políticas para os países da América Latina, Ásia e Caribe.

A EaD é ressaltada nesse documento do Banco como sendo como uma eficiente estratégia de diversificação das instituições de ensino superior, garantindo o acesso aos segmentos populacionais mais pobres, sem aumentar muito os custos da educação superior, além de ser importante para proporcionar a formação em serviço dos professores, como destaca o documento do BM:

[...] la educación a distancia pude ser eficaz para aumentar a um costo moderado el acceso de los grupos desfavorecidos, que por lo general están deficientemente representados entre los estudiantes universitários. [...] puede ser uma forma eficaz de promover también la educación permanente y de mejorar los conocinimentos, por ejemplo, cuando se usa para la formacón de los maestros em el serviço. (BM, 1995, p.36). 
Documentos mais recentes do Banco ressaltam a importância do papel do professor para a formação do aluno e, nesse sentido, a formação do próprio professor se faz necessária para que ele cumpra esse papel. O documento de 2014, "Professores Excelentes: como melhorar a aprendizagem dos estudantes na América Latina e no Caribe" tem um tópico específico desenvolvido para mostrar o porquê o professor é importante, destacando que a eficácia do desenvolvimento econômico dos países ocorre pela contribuição do capital humano e pelo o que os alunos aprendem e não pelo tempo de estudo.

Não se discute que uma definição completa de qualidade do professor deve abranger muitas características diferentes e dimensões do desempenho do professor. Mas a capacidade dos professores de assegurar que seus alunos aprendam é condição sinequa non para que alunos e países colham os benefícios econômicos e sociais da Educação. (BM, 2014, p.6).

Documentos da UNESCO têm demonstrado esses interesses quando apoiam e valorizam ações de formação de professores por meio da educação a distância, conforme destacamos no Capítulo II. Como pontuou Malanchen (2008), a principal diretriz desse OI na última década foi a defesa do programa "Todos pela Educação" desde a Conferência em Jontien em 1990, passando pela Conferência de 1994 e o Relatório de Delors de 1997, em que a educação é colocada como "chave mágica para a resolução de todos os problemas que se referem à justiça social", assim como a EaD que é colocada como "motor do desenvolvimento econômico, lugar de alta especialização, adaptada a economia e à sociedade". (MALANCHEN, 2008, p.184).

O documento "Educação para Todos: o compromisso de Dakar”, (2001) ao reconhecer a importância do professor e as necessidades de sua formação e valorização, aponta que essa formação pode ser realizada por meio da formação em serviço e a distância, utilizando-se dos recursos das tecnologias da comunicação e informação (TIC) como aliados aos programas de formação. Assim o documento é enfático ao demonstrar estratégias sobre a utilização das novas tecnologias.

É preciso aproveitar o potencial das TIC para [...] aperfeiçoar o acesso à educação por comunidades remotas e desfavorecidas; para dar apoio ao desenvolvimento profissional inicial e continuado de professores, e proporcionar oportunidades de comunicação entre matérias e disciplinas e entre as culturas. (UNESCO, 2001, p.25).

No documento intitulado "Conferência Mundial sobre Ensino Superior - As Novas Dinâmicas do Ensino Superior e Pesquisas para a Mudança e o Desenvolvimento Social” de 
2009, relatório das atividades da Conferência Mundial de Ensino Superior que ocorreu na sede da UNESCO em Paris, apresenta também o reconhecimento e a preocupação com o investimento na educação superior apostando assim na EaD e na introdução das TICs para a educação.

Nossa habilidade em atingir as metas da EPT depende de nossa habilidade de suprir a carência mundial de professores. A educação superior deve atualizar a educação dos professores, tanto no pré-serviço quanto em serviço, com um currículo que prepare os professores para formar indivíduos com o conhecimento e as habilidades que eles precisam para o século 21. Isso demandará novas abordagens, inclusive ensino a distância (EaD) e tecnologias de Informação e Comunicação (TIC). (UNESCO, 2009, p. 3).

No entanto, como vimos no Capítulo II, o reconhecimento à educação e apoio à formação dos profissionais da educação pelos OIs para a utilização da $\mathrm{EaD}$ apresentam-se como um discurso de uma Política Oficialmente Declarada - POD, pois na sua essência, na Política de Fato - POF, trata-se de interesses de formação que enfatizam o conhecimento pedagógico das técnicas de ensino em detrimento do conteúdo, como pontuou Vieira e Moraes (2014), que o BM "não considera o professor como insumo mais importante em sala de aula, colocando, antes dele, a biblioteca, os livros didáticos, entre outros" e, nesse sentido, o interesse de formação está associado aos interesses do capital humano.

Malanchen (2008) também corrobora essa questão pontuando que, embora os documentos da UNESCO atribuam ênfase ao papel do professor para os processos formativos, as orientações para formação deles por meio de cursos a distância sugerem que "o fundamental são os meios e, como tal, a formação deve estar centrada no aprender a aprender a lidar com eles" (p.184). A autora aponta que o foco dos documentos desse OI está na busca de formação de habilidades e saberes considerando o progresso científico e tecnológico.

Considerando os períodos de governo presidenciais no Brasil e o financiamento dado às políticas de EaD, Silva, Oliveira e Costa (2011) assinalam que um dos eixos destacados durante o primeiro mandato de governo de Dilma Rousseff e que é marcado pela continuidade dos governos de Luiz Inácio Lula da Silva (Lula) e Fernando Henrique Cardoso (FHC), é a “garantia da educação para igualdade social, a cidadania e o desenvolvimento".

Para tanto, nas pretensas reformas educacionais propostas e desenvolvidas nesses governos, destaca-se, dentre seus objetivos, a questão da "universalidade do acesso e a inclusão da possibilidade de novas tecnologias na educação por meio da autorização de abertura e certificação de cursos superiores de graduação a distância" (SILVA, OLIVEIRA, 
COSTA, 2011, p.9). Segue-se a isso, o grande investimento pretendido a partir da intensificação aos cursos na modalidade EaD.

No entanto, esses objetivos são questionados pelos autores quando procuram compreender se esse "modelo pretendido" não seria mais um instrumento de reprodução de novas formas de produção de capital humano para atender aos interesses do capitalismo, o que outras pesquisas vêm demonstrando que sim.

Para Mota Júnior e Maués (2014), a ideia central da teoria do capital humano é a de um acréscimo marginal de instrução, treinamento e educação como capacidade de produção. Trata-se de "uma quantidade ou um grau de educação e de qualificação" considerando como indicativo um "determinado volume de conhecimentos, habilidades e atitudes adquiridas, que funcionam como potencializadoras da capacidade de trabalho e produção". (p.1147).

Apoiados em Frigotto (2000) os autores sinalizam que essa visão se trata na verdade de um mito, por sua vez muito difundido na sociedade que tenta justificar que a educação seria a "grande panaceia para superar a pobreza e as desigualdades sociais em termos tanto macro como microeconômicos”. (MOTA JÚNIOR, MAUÉS, 2014, p.1148).

Dessa forma, concordamos com os apontamentos de Bonetti (2007), ao assinalar que as políticas públicas devem ser pensadas no conjunto que integram o Estado e a sociedade civil, considerando que elas nascem dos anseios e das necessidades sociais, embora nem sempre sejam significantes para todos. Desse modo, se é anseio dos profissionais da educação contar com uma formação de qualidade social, e se o governo declara por meio de uma Política Oficialmente Declarada - POD, as possibilidades de formação, isso não quer dizer que elas representem as políticas que responderão aos anseios históricos.

Discorrendo sobre a caracterização das políticas públicas para compreender sua gênese, seus princípios determinantes, a forma de elaboração e operacionalização para se entender o que elas representam, Bonetti (2007) ressalta que elas são "ações que nascem do contexto social, mas que passam pela esfera estatal como uma decisão de intervenção pública numa realidade social". Além disso, é o "resultado da dinâmica do jogo de forças que se estabelecem no âmbito das relações de poder", sendo que essas relações "determinam um conjunto de ações atribuídas à instituição estatal”. (p.740).

Höfling (2001) também argumenta que as políticas sociais - e a educação - situam-se no interior de um tipo particular de Estado. São formas de interferência dele visando à manutenção das relações sociais de determinada formação social. Portanto, assumem 
"feições" distintas em diferentes sociedades. É impossível pensar o Estado fora de um projeto político e de uma teoria social para a sociedade como um todo.

Considerando o período histórico, econômico e produtivo mundial que vivemos, a racionalidade global e tecnológica que diretamente reflete e exige mudanças em todos os setores no Brasil, Bonetti (2007) destaca que, de forma geral, as políticas públicas têm se constituído por "uma correlação de forças sociais, conjugando interesses específicos e/ou de classes, em que os interesses das classes política e/ou economicamente dominantes, têm prevalência, mas não unanimidade". (Grifos nosso). Ademais, os argumentos utilizados por Bonetti (2007) referem-se à concepção de que a constituição do Estado atual não considera a existência de diferenças sociais na sociedade.

Assim, a concepção de Estado nesse ideal, aposta na homogeneização das diferenças a partir de certo "padrão referencial", o qual se considera o que está no "auge", o que aparece como modismo em um determinado momento histórico e, no caso em tela, trata-se do padrão da racionalidade tecnológica. Mas, se a competência tecnológica representa um "padrão referencial" exigido na atualidade para igualdade das diferenças, o Estado não mede esforços para garantir e promover, entre os indivíduos e a sociedade civil, espaços de permanente competitividade, subordinando as políticas sociais às políticas de mercado, sendo essas, responsáveis por regular aquela esfera.

Dessa forma, esse padrão de referencial hegemônico exige que os indivíduos se esforcem ao máximo para serem iguais, para que desenvolvam hábitos culturais e de consumo constante, mesmo que não seja necessidade básica, mas para que acompanhem essa racionalidade imposta. Importa que se qualifiquem se tornem competentes, adquiram saberes técnicos para assumir cargos e funções, sejam produtivos e, assim, acompanhem a racionalidade imposta na chamada "Sociedade do Conhecimento", a partir dos discursos de inclusão tecnológica e social.

Ocorre que entre a formulação das políticas públicas e a ação das forças sociais, considerando seus interesses de classe, há uma relação direta com o discurso pretenso da inclusão, sobretudo da inclusão tecnológica, ou seja, um discurso ideológico. No caso dessas políticas de inclusão, destacando-se as que são formuladas para formação de professores, e dos profissionais da educação como um todo por meio de cursos a distância e que usam

\footnotetext{
${ }^{6}$ Para Duarte (2008), a "Sociedade do Conhecimento" é uma ideologia produzida pelo capitalismo, é um fenômeno no campo da reprodução ideológica do capitalismo, "uma ilusão que cumpre determinada função ideológica na sociedade capitalista contemporânea". O papel desempenhado por esse tipo de sociedade é "enfraquecer as críticas radicais ao capitalismo e enfraquecer a luta por uma revolução que leve a uma superação radical do capitalismo, gerando a crença de que essa luta teria sido superada". (p.13).
} 
tecnologias com finalidades de inclusão, o saber técnico nem sempre levará ao caminho da inclusão social, pois, em grande parte, ele representa, no discurso ideológico do Estado, um instrumento de controle, em que só terão direito aqueles que têm condições de ter acesso a essa racionalidade técnica.

Se a visão de homogeneização das diferenças sociais aparece como um discurso pretensamente ideológico de uma classe dominante que até reconhece as necessidades de políticas públicas para a formação dos profissionais da educação, isso não quer dizer que, quando materializadas, vão de fato significar soluções e responder aos anseios históricos por formação de qualidade e formação para emancipação.

Considerando as análises de documentos dos OIs e suas diretrizes para a formação dos profissionais da educação e tendo em vista os resultados de pesquisas sobre cursos em $\mathrm{EaD}$, conforme apresentamos, vemos que a preocupação com a formação se relaciona ao fornecimento de conhecimentos básicos e necessários para que os profissionais da educação tenham competência sobre o processo de ensino aprendizagem e, no caso dos professores/gestores, espera-se que esses possam administrar melhor a escola.

Nessa concepção, o sistema educacional não carece apenas de investimentos financeiros, mas sim de profissionais eficientes para gerir os recursos, assim como necessita de professores eficazes para administrar a formação dos alunos, segundo os interesses econômicos.

Dessa forma, os OIs impõem suas diretrizes por meio de consensos e ideias, mas que retratam apenas uma aparência quando, de fato, são mecanismos que mascaram sua essência, e, portanto, põem-se invertidos, como aponta Fiorin (2005), considerando que temos dois níveis de realidade "um de essência e um de aparência, ou seja, um profundo e um superficial, um não visível e um fenomênico". (p.28).

No Capítulo II vimos que as reformas educacionais desenvolvidas no Brasil, a partir dos anos de 1990, materializam-se nesse contexto de respostas às diretrizes dos OIs sob as orientações neoliberais, tendo em vista os compromissos assumidos pela agenda educacional, política e econômica do país a partir de compromissos realizados nas conferências e encontros internacionais, como em Jontien, Nova Delhi e Dakar, que demarcam "sua primeira expressão orgânica do movimento reformista mundial com o Plano Decenal de Educação para Todos, na esfera da educação", como destaca Silva Júnior, Kato e Santos (2010, p.36).

Esses autores analisam dois programas de educação a distância considerando a reforma do Estado brasileiro e da educação, em busca de respostas sobre as implicações 
teóricas, políticas e práticas do contexto vivido para a formação de professores por meio dessa modalidade. Eles lembram que, na dimensão docente, a reforma produzida no núcleo estratégico do Estado, segundo indicações do MARE, sinaliza que o professor e os dirigentes educacionais são agentes centrais de mudanças para as pretensas reformas considerando que os discursos oficiais justificavam sua realização afirmando que a gestão pública era ineficiente, rígida e burocrática e, portanto, necessitava ser alterada para se desenvolver por mecanismos mais flexíveis, modernos e eficientes de gestão.

Considerando que a "educação é uma esfera social de formação humana e, como tal, realizam-se no âmbito das relações sociais”, Silva Júnior, Kato e Santos (2010) apontam que a formação de professores desenvolvida por meio da EaD, nesse contexto mais amplo de ressignificação do papel do Estado e de reformas educacionais, parece "enfatizar uma pseudoformação articulada a uma submissão política do Brasil aos organismos multilaterais". (p.47). Chegam a essa reposta considerando que as políticas de formação parecem seguir a mesma racionalidade das reformas administrativas.

\begin{abstract}
A EaD põe-se como uma prática instrucional entre sujeitos, mediada por tecnologias de informação e comunicação com foco no processo de ensinoaprendizagem, num contexto tal em que a objetividade social apresenta um horizonte de possibilidades orientado pela racionalidade mercantil produzida pela mudança nas estruturas sociais, resultado do processo de reformas que se assistiu no país na segunda metade da década de 1990. (p.50).
\end{abstract}

Diferentemente das características anunciadas no tópico anterior desenvolvidas nesse capítulo, as quais apontam características da $\mathrm{EaD}$ e possibilidades de haver uma boa formação de profissionais da educação, Silva Júnior, Kato e Santos (2010) não concordam e defendem que a "prática escolar desse ser presencial, se o objetivo for não somente a instrumentalização do ser humano, mas a elevação de sua condição de ser”. (p.49). Apontam que os programas de $\mathrm{EaD}$, financiados pelo governo e pelas instituições privadas, apresentam-se como sustentação teórica às "pedagogias do aprender a aprender"" ou ao modelo da pedagogia das competências" $"$. (p.49).

\footnotetext{
${ }^{7}$ A pedagogia do aprender a aprender é um dos lemas da chamada Sociedade do Conhecimento, como aponta Duarte (2008). É uma ilusão, um lema educacional. Sua concepção de criticidade não se refere à busca por transformações radicais na realidade social, mas sim em termos de capacidade de encontrar novas formas de ação que permitam melhor adaptação aos ditames da sociedade capitalista”. (p. 12).

${ }^{8}$ Silva (2010) ressalta que "o modelo da pedagogia das competências apresenta similaridades inequívocas com o discurso da gestão por competências, tão apregoadas nos cursos de Administração de Empresas" e baseando-se em Heloani (2003) destaca que "as novas formas de gestão reproduzem a essência da gestão taylorista-fordista, calcada na racionalidade instrumental e econômica”. (p.97).
} 
Gomes (2010) também corroborando essa ideia, argumenta, a partir de uma reflexão teórica e filosófica, que a educação superior brasileira parece não saber qual sua função social, desenvolvendo mais um caráter performático, reduzindo sua finalidade a uma função pragmática e utilitária que é guiada "pelo investimento em determinadas áreas do conhecimento que possam promover, em nome do critério da utilidade e do lucro, o desenvolvimento técnico e instrumental da sociedade". (p.121). Nesse caso, a EaD e a formação de profissionais da educação por essa modalidade acompanham esse mesmo cenário.

Na concepção de Borges (2002), a educação a distância se apresenta como um álibi ao projeto neoliberal tendo em vista que ela vem representando uma adaptação do sistema educacional ao mercado de trabalho quando os cursos, embora apresentem discursos de formação crítica e emancipatória, preocupam-se com uma formação em massa, guiam-se por orientações gerais para todos as regiões do país, considerando o público de forma homogênea e igual, oferecem materiais instrucionais e padronizados, dentre outras características, que são justificadas pelo deslocamento da formação humana do campo social para o campo econômico.

[...] acreditamos que o tripé neoliberal para a educação realmente vem para garantir não a qualidade, a eficiência e a equidade do sistema educacional, a partir da igualdade das oportunidades e de uma prática educativa libertária, na qual a aprendizagem é fruto da participação de sujeitos cognoscentes diante da construção do conhecimento, e sim para garantir a qualidade necessária à racionalidade empresarial para o cumprimento das exigências do mercado capitalista. Enquanto obedece à lógica do capital, nem os modelos de educação a distância nem as tecnologias que são instrumentos para tais modelos, contribuirão com a transformação social e com a humanização da sociedade, pois suas relações baseiam-se na lucratividade em detrimento da equidade. (p.117).

No mesmo sentido, a pesquisa de Malanchen (2008), que tomou documentos da UNESCO para compreender a configuração da educação a distância no Brasil, demarca que a formação de professores por meio da $\mathrm{EaD}$ faz parte de um conjunto de diretrizes e consensos ideológicos, por sua vez fundamentados pela globalização e "sociedade do conhecimento", que pretendem tornar esses profissionais flexíveis e controláveis para que aceitem as reformas. 


\subsection{Síntese do Capítulo}

Na reflexão desenvolvida neste capítulo, vemos que existem argumentos favoráveis de que a educação a distância se apresente como uma modalidade de educação em que a educação desenvolvida represente de fato uma postura emancipadora e contribua para a formação e a transformação de novos indivíduos.

Essa postura é corroborada por nós tendo em vista que a consideramos como educação, e como tal, seus princípios e sua função social devem ser os mesmos da educação na modalidade presencial, ou seja, por ser uma apropriação da cultura, é objetivada de geração a geração a partir do processo de formação da individualidade como coloca Duarte (2008) que, com base em Marx (1978), afirma que o indivíduo precisa apropriar-se dos resultados da história e fazer desses resultados os órgãos da sua individualidade. Isso independe se de forma presencial ou a distância.

No entanto, vemos por outro lado, a partir de argumentos contrários a essa visão, que a $\mathrm{EaD}$, da forma como tem sido implantada e desenvolvida no Brasil, não está conseguindo desenvolver esses objetivos, considerando suas bases de sustentação a partir de um referencial hegemônico pautado nas diretrizes da retórica da sociedade do conhecimento.

Esses argumentos e posturas fazem partem de visões de mundo diferenciadas e se apresentam coerentes a partir de suas concepções. Considerando que fazem parte de uma totalidade, não podem ser entendidos de forma separadas e, portanto, questões essenciais devem ser levadas em consideração, como a postura política e autônoma da educação, o fato de que as classes subalternas precisam ter consciência e lutar por mudanças alcançando patamares contra-hegemônicos, além de que, os intelectuais devem agir para manter o consenso entre os projetos dos grupos, relacionando o tempo todo o princípio educativo do trabalho na visão marxiana.

Após discutirmos esses importantes aspectos de ordem mais teórica sobre as origens do Estado, suas ressignificações à luz do ideário capitalista e neoliberal, sob a vigilância e influência dos organismos internacionais nas políticas públicas e sociais do Brasil e também de compreendermos alguns dilemas pelos quais a educação a distância tem passado, passamos à compreensão do referencial empírico de forma a melhor situarmos o objeto de estudo. 
PARTE II - A Pesquisa Empírica 


\section{CAPÍTULO IV- O PROGRAMA NACIONAL ESCOLA DE GESTORES DA EDUCAÇÃO BÁSICA - AÇÃO DAS POLÍTICAS DE FORMAÇAO DE GESTORES}

Os filósofos apenas interpretam o mundo de diferentes maneiras; porém, o que importa é transformá-lo.

Marx, Engels, 2009.

\subsection{Apontamentos Iniciais do Capítulo}

Compreendemos que se faz necessário conhecer as origens e as principais características do Programa Nacional Escola de Gestores para melhor entendermos a experiência do curso de especialização lato sensu em Coordenação Pedagógica desenvolvido no Tocantins pela UFT e seus parceiros no período de 2010 a 2011.

Esse capítulo apresenta as características mais gerais do PNEGEB a partir do estudo documental sobre os documentos primários do Programa, dentre eles o "Projeto Básico: Programa Escola de Gestores" (2004), as "Diretrizes Nacionais do Programa Escola de Gestores da Educação Básica" (2009), assim como o "Projeto Pedagógico do Curso de Especialização em Coordenação Pedagógica do MEC" (2009).

Também realizamos análises dos documentos de criação e implantação do curso de especialização lato sensu para Coordenador Pedagógico ofertado pela UFT, dentre eles o "Projeto de Especialização em Coordenação Pedagógica da UFT" (2010), o "Relatório Final de Curso" (2012), o "Relatório de Avaliação do Curso" (2012), os "Editais de Seleção do Curso" (2010) e o "Plano de Trabalho Anual da UFT" (2009).

Nesse movimento de compreensão, também foi importante somar, às vozes desse estudo, as de outros cursos ofertados em diversas regiões no Brasil de forma a que, por meio da categoria dialética da totalidade, fosse possível alcançar o concreto pensado.

Assim, apresentamos também algumas experiências do PNEGEB no Brasil a partir de um mapeamento sobre as produções referentes a esse Programa por meio do levantamento de pesquisas de mestrado e doutorado disponíveis no portal de Teses e Dissertações da Coordenação de Aperfeiçoamento de Pessoal de Nível Superior (CAPES). 


\subsection{Gênese e Características do PNEGEB}

O contexto das políticas públicas para a educação no Brasil, sua gênese e desenvolvimento ganham maior destaque após os anos de 1990, com a Lei de Diretrizes e Bases da Educação n 9394 de 1996 e com a Reforma Gerencialista desenvolvida no Estado brasileiro a partir das ações empreendidas no governo do presidente FHC (1995-2002), que, por sua vez, tem continuidades nos governos posteriores como vimos nos capítulos anteriores.

Nesse contexto, perpassam os discursos de modernização da gestão pública amparada, entre outras diretrizes, pelos consensos estabelecidos pelos Organismos Internacionais direcionados pelo capital em sua fase neoliberal. Mais especificamente sobre as políticas para formação de profissionais da gestão escolar, Aguiar (2011) ressalta que elas tiveram um grande impulso a partir do ano de 2003, já no governo do presidente Luiz Inácio Lula da Silva (Lula).

A autora ressalta, como justificativas da implantação dessas políticas, razões relacionadas tanto aos acordos internacionais que buscam uma "gestão eficiente e eficaz como o elemento chave para assegurar a boa qualidade do sistema de ensino e das escolas", quanto também, impulsionadas por questões que situam a participação de movimentos da sociedade civil organizada por meio de diversas entidades do campo educacional, os quais conseguiram “inscrever a gestão democrática da educação como princípio constitucional, além de sua contribuição ao debate sobre políticas da área”. (AGUIAR, 2011, p.2).

No Brasil, dentre outras ações, o processo de formação para os profissionais da gestão escolar vem sendo apoiado por meio do PNEGEB. Esse Programa inicia suas ações sob a coordenação do Instituto Nacional de Estudos e Pesquisas Anísio Teixeira (Inep), tendo sido formulado em 2004 como um projeto básico, intitulado de "Programa: Escola de Gestores", durante o período de governo do presidente Lula. Posteriormente, foi reformulado e continua vigente dentre as ações de formação para gestores escolares nos governos da presidente Dilma Rousseff, considerando como referência o ano de 2015, recorte temporal desta pesquisa.

Castro (2012) argumenta que a criação do PNEGEB se apresenta como o embrião de uma política de formação de gestores no Brasil que teve como foco os princípios da gestão democrática, a formação em serviço e a educação a distância. Trata-se da institucionalização de uma política de formação nacional para gestores escolares, o que também é sinalizado pelo documento de Diretrizes Nacionais do Programa em 2009. 
O PNEGEB, de acordo com esse autor, representa uma iniciativa pioneira como política sistematizada para a formação de gestores no Brasil. Assim destaca alguns fatores determinantes para sua criação:

a) as diretrizes elaboradas e disseminadas pelos organismos internacionais; b) as novas demandas para organizar a escola de forma mais eficiente e articulada com os novos paradigmas da reforma do Estado; c) a precariedade da formação de escolha de diretores, na maioria das vezes realizado por indicação, fez com que a formação dos gestores educacionais da escola pública passasse a ser uma necessidade e começasse a fazer parte da agenda das políticas educacionais. (CASTRO, 2012, p.6)

Fernandes (2015) também afirma que o PNEGEB se caracteriza como um Programa que surge como demandas de apoiar ações de formação continuada para gestores da educação básica de escolas públicas, num contexto em que a gestão escolar, assim como a educação de modo geral, é alvo da necessidade de profissionalização e modernização tão exigidas pelas diretrizes internacionais, considerando os discursos em prol da busca por qualidade na educação.

O Projeto básico aponta que o Programa surgiu considerando as necessidades de processos de gestão escolar compatíveis com uma concepção voltada para o alcance de qualidade social da educação. Destaca que seus princípios estão voltados para "a moderna administração pública e de modelos avançados de gerenciamento de instituições de ensino públicas". (PROJETO BÁSICO, 2004, p.1). (grifos nossos).

Desse Projeto Básico, destacamos seus objetivos gerais que visavam proporcionar:

-a formação continuada do gestor escolar para o efetivo exercício da liderança enquanto componente mediador, integrador e catalisador dos esforços da escola como um todo para a realização de suas propostas educativas;

-o fornecimento de instrumentos para a qualificação dos processos e procedimentos da gestão escolar tendo em vista a melhoria da qualidade do ensino;

-o conhecimento e a aplicação de processos de trabalho com a utilização da tecnologia como ferramenta gerencial no cotidiano da escola. (PROJETO BÁSICO, 2004, p. 14).

Embora o Projeto mencione a gestão escolar como um termo amplo, mostrando-se na forma de sua Política Oficialmente Declarada - POD, a leitura e interpretação do documento levam-nos a inferir que na Política de Fato - POF, a gestão está associada apenas à figura e ao trabalho do diretor da escola, como se percebe em alguns trechos do Projeto: "o protagonismo do diretor escolar na contribuição da escola para um projeto de nação e na liderança 
comunitária" (p.4), (grifos nossos) e também no item sobre a metodologia do Projeto quando discorre que: "Pretende-se formar diretores de escolas de todo o País, por meio da formação continuada em serviço, permitindo que esses profissionais possam ser qualificados no próprio espaço de trabalho". (p.4). (grifos nossos).

Também compreendemos que, nesse Projeto, o discurso é claro, ou seja, a POD declara a compreensão e preocupação com a formação de gestores que possam acompanhar as mudanças da gestão pública, no que refere à modernização e gerenciamento das ações administrativas. Nessa concepção original do Programa, parte-se do princípio da busca pela modernização da gestão como um dos elementos para se alcançar educação de qualidade, que tem suas raízes nas diretrizes estabelecidas pela reforma administração pública dos anos de 1990, como discutimos nos capítulos anteriores, e que tem continuidade nas políticas educacionais dos anos 2000 .

Vemos que as políticas públicas desde 1996 apontam para a centralidade sobre a democratização da educação e da escola e dos modelos de descentralização e da gestão colegiada dos sistemas de ensino. Também há um grande enfoque sobre as questões referentes à formação inicial e continuada de professores e gestores, por meio da capacitação e atualização em serviço, que buscam a melhoria da gestão, do processo pedagógico participativo, bem como, a ampliação dos mecanismos de avaliação interna e institucional em busca da garantia de qualidade.

Essas primeiras aproximações e inferências se apresentam importantes, tendo em vista que o contexto de criação do PNEGEB e os discursos da proposta inicial demonstram compactuar com uma visão hegemônica de que a formação de gestores se faz necessária, mas que suas bases se assentam nos interesses das classes que consentem que a técnica, a tecnologia e formação em serviço garantirão uma inclusão social e o desenvolvimento social.

No entanto, essas primeiras impressões vão sendo reformuladas ao longo das análises dos documentos. No ano de 2005, PNEGEB inicia suas ações com a oferta de um projeto piloto ofertando 400 vagas para o curso de extensão em gestão escolar para gestores em exercício de escolas estaduais e municipais em dez estados brasileiros, sendo eles o Ceará, Pernambuco, Bahia, Piauí, Rio Grande do Norte, Mato Grosso, Espírito Santo, Santa Catarina, Rio Grande do Sul e o município de Palmas no Tocantins.

Esse curso piloto utilizou como suporte tecnológico o ambiente virtual de aprendizagem (AVA) e-proinfo que é um ambiente colaborativo de aprendizagem 
desenvolvido pela antiga Secretaria de Educação a Distância (SeeD) do MEC e por colaboradores de outras instituições no país.

A partir desse projeto piloto e tendo em vista uma avaliação do Programa para sua posterior normatização, o MEC propõe algumas alterações. Fernandes (2015) destaca, por exemplo, a mudança do ambiente de aprendizagem e-proinfo para outro com mais suporte tecnológico, de forma a que possibilitasse maior interatividade nas ações dos cursos, apontando que muitas instituições formadoras optaram pelo uso da plataforma moodle ${ }^{9}$.

Aguiar (2010) também aponta, dentre as mudanças, que o Programa passa a oferecer o curso de especialização lato sensu em Gestão Escolar e que o PNEGEB deixa de ser coordenado pelo Inep, passando a integrar ações do próprio MEC a partir do Plano de Desenvolvimento da Educação (PDE).

O Programa Escola de Gestores também passou por mudanças a começar pela sua transferência do Inep, no início de 2006, para o âmbito e coordenação da Secretaria de Educação Básica (SEB) deste ministério. Tal mudança visava assegurar maior unidade dos programas direcionados à educação básica [...] Além disto, este programa, posteriormente, passou a integrar o Plano de Desenvolvimento de Educação (PDE). (AGUIAR, 2010, p.4).

Em outro texto, Aguiar (2011) também ressalta que as mudanças no Programa estão diretamente ligadas com questões internas do próprio MEC considerando os resultados do período político vivido pelo país naquele contexto.

Com a saída do Ministro da Educação Tarso Genro, em julho de 2005, motivada, sobretudo, pelos arranjos do processo eleitoral em curso no país e a assunção do Ministro Fernando Haddad, ocorreram, como é de praxe na dinâmica da política brasileira, re-orientações das políticas e dos procedimentos administrativos internos ministeriais [...] Interessa, neste texto, destacar a mudança que ocorreu no Programa Escola de Gestores que passou, a partir de janeiro de 2006, para a esfera de coordenação da Secretaria de Educação Básica- SEB deste Ministério, sofrendo várias alterações no tocante aos conteúdos e configuração institucional. (p.165).

Nesse movimento de apreensão sobre as origens e características do PNEGEB, considerando que ele passa a integrar as ações do Plano de Desenvolvimento de Educação (PDE), faremos um breve adendo para situarmos esse Programa nesse contexto de alterações, visando compreender a institucionalização dessa inserção.

\footnotetext{
${ }^{9}$ Moodle - sistema de gerenciamento de cursos (Course Management Sistem - CMS). Possibilita o trabalho colaborativo entre os participantes em um mesmo ambiente de aprendizagem mediante o uso da internet. Software livre de código aberto distribuído gratuitamente - significa que o usuário pode modificar, usar e distribuir de acordo com suas necessidades didáticas e de conteúdo. (RAMOS, MEDEIROS, 2009).
} 


\subsubsection{O PNEGEB no contexto do PDE}

O Plano de Desenvolvimento de Educação - PDE foi criado pelo ministro da educação Fernando Haddad no governo Lula em 2007 e constitui-se em um conjunto de ações e metas para melhorar a educação básica do Brasil em todas as suas etapas, elevando o nível da educação ao dos países desenvolvidos em um período de 15 anos. Assim, desde seu lançamento, a previsão é que até o ano de 2022, essa política tenha resolvido os problemas sobre a qualidade da educação no país.

Entre os compromissos assumidos pelo PDE, tem-se o Plano de Metas Compromisso Todos Pela Educação que foi instituído pelo Decreto Federal $n^{\circ}$. 6.094/2007 como uma estratégia para regulamentar o regime de colaboração entre os municípios, estados e Distrito Federal, bem como incentivar a participação das famílias e da comunidade, de forma a garantir uma mobilização social para o alcance da melhoria da qualidade da educação básica.

Essa integração dos entes federados ocorre por meio da assinatura de um termo de adesão na forma de "compromisso" que implica que, aqueles que aderirem a esse Plano estarão assumindo o compromisso de "28 diretrizes pautadas em resultados de avaliação de qualidade e de rendimento dos estudantes". (PORTAL MEC, ACS).

O MEC publicou um Guia em 2007 apresentando os Programas constituintes do Plano de Metas Compromisso Todos Pela Educação, os quais na época somavam quase 65 programas subdivididos nas áreas da gestão educacional (com 18 ações), na área de formação de professores e profissionais da educação (com 21 programas) e na área de infraestrutura e apoio educacional (com 25 ações).

Assim, o PNGEB, Programa criado em 2004, foi disciplinado institucionalmente em 2009, passando a ser gerenciado pela SEB/MEC e integrando as ações desse Plano de Metas, como uma ação do PDE. O artigo primeiro da Portaria Ministerial n ${ }^{\circ}$ 145/2009 que disciplina legalmente o PNGEB ressalta e caracteriza-o como um Programa que pode ofertar "cursos de formação continuada voltada para a gestão escolar, de acordo com as necessidades das escolas e dos profissionais de educação dos sistemas de ensino de educação básica pública".

A referida Portaria (2009) destaca a articulação do Programa com o Plano de Metas integrante das ações do PDE, ressaltando em seu artigo $4^{\circ}$ que uma das condições para os estados e municípios que queiram participar do PNEGEB é a de que eles tenham "aderido formalmente ao Plano de Metas Compromisso Todos pela Educação" e que sigam "as 
orientações e diretrizes estabelecidas em Resolução do Fundo Nacional de Desenvolvimento da Educação (FNDE)".

Sobre esse Plano de Metas, Saviani (2007b) assinala, no entanto, que ele foi considerado como o "carro-chefe" do PDE e que é um grande "guarda-chuva" que abriga todos os programas já existentes no MEC:

Ao que parece, na circunstância do lançamento do Programa de Aceleração do Crescimento (PAC) pelo governo federal, cada ministério teria que indicar as ações que se enquadrariam no referido Programa. O MEC aproveitou, então, o ensejo e lançou o Índice de Desenvolvimento da Educação Básica (IDEB) e a ele atrelou as diversas ações que já se encontravam na pauta do Ministério, ajustando e atualizando algumas delas. Trata-se, com efeito, de ações que cobrem todas as áreas de atuação do MEC, abrangendo os níveis e modalidades de ensino, além de medidas de apoio e de infraestrutura. (SAVIANI, 2007b, p.3)

Dourado (2007) argumenta que o PDE é um dos programas centrais na área da gestão que compõe o Fundo de Fortalecimento da Escola (FUNDESCOLA). Desde sua origem, o PDE busca conformar o ideal de melhoria educacional associado aos parâmetros de mercado, de autonomia restrita e ao caráter diretivo e centralizador, tendo em vista a ressignificação do conceito de gestão democrática e da participação por meio de mecanismos e instrumentos coletivos nas escolas.

O autor pondera também sobre o distanciamento dos ideais do PDE em relação com os marcos legais, os princípios da gestão democrática e, ainda, com as próprias ações do FUNDESCOLA, quando a gestão dele passa para o FNDE, ocorrendo "sobreposição de ações e planos e programas com concepções político-pedagógicas distintas no âmbito do governo federal". (p.932). Dessa forma, Dourado (2007) ressalta que o PDE tem "foco e ação políticopedagógica baseados em concepção gerencial”. (p.12).

Como veremos mais adiante, o PNEGEB como ação do PDE, coloca como requisito a participação de gestores de escolas que tenham baixo IDEB. No entanto, na visão de Freitas (2007), esse índice utilizado para medir o desenvolvimento da educação básica representa mais um mecanismo de regulação do que de inovação ou, como pontua Veiga (2003), uma inovação regulatória e técnica. 
4.2.2 Diretrizes e objetivos do PNEGEB após a revisão do programa

A partir dessa breve contextualização da inserção do PNEGEB ao PDE, retomamos aos documentos oficiais, os quais apresentam, dentre as justificativas para sua criação, as avaliações e resultados do Sistema de Avaliação Básica (SAEB) e dos dados do Censo Escolar, que apontam problemas com o baixo desempenho dos estudantes e a preocupação com a melhoria da qualidade da educação das escolas públicas.

Tendo em vista os compromissos dos governos assumidos em torno da melhoria pela qualidade da educação nos encontros mundiais, desde 1990, o governo de Lula buscou incentivar ações para melhorar essa situação por meio do fortalecimento de uma gestão escolar democrática e que pudesse garantir mudanças nos índices apresentados.

No documento de Diretrizes Nacionais do Programa (2009), as justificativas para implantação do PNEGEB pontuam essas questões de baixos indicadores educacionais e também associam à preocupação com as diferentes formas de provimentos de cargos de gestores escolares e com o baixo nível de formação escolar desses profissionais.

A necessária dinamização e efetivação de programas, projetos e ações
direcionados à formação continuada de gestores escolares, se fazem
presentes em função dos indicadores educacionais no País e, ainda, em
função das novas formas de provimento ao cargo de gestor escolar em
vigência nos estados e municípios. Os dados recentes do Censo Escolar/2007
indicam que, no Brasil, a realidade da gestão escolar é bastante diversa no
que se refere à formação dos dirigentes. Do total de dirigentes escolares,
$29,32 \%$ possuem apenas formação em nível médio, sobretudo nos estados
das regiões norte, nordeste e centro-oeste. O percentual desses dirigentes
com formação em nível superior é de $69,79 \%$, enquanto apenas $22,96 \%$
possuem curso de pós-graduação lato sensu/especialização. (BRASIL,
MEC/DN/PNEGEB, 2009, p. 6).

Em relação aos objetivos do Programa, o documento de Diretrizes enfatiza sua pretensão de contribuir com a "formação efetiva de gestores educacionais da escola pública, de modo que disponham de elementos teórico-práticos que viabilizem uma educação escolar básica com qualidade social". (p.6). Os gestores educacionais, nesse documento de 2009, diferentemente daquele de 2004, referem-se aos profissionais da educação, ou seja, aos professores/gestores que "exerçam o cargo de diretor ou vice-diretor de escola ou demais cargos de gestão pedagógica”. (PM n ${ }^{\circ}$ 145/2009, Art. $2^{\circ}$ ).

De modo geral, os objetivos das Diretrizes do PNEGEB pretendem que suas ações, por meio dos cursos de formação continuada, possam: “Aprimorar a formação do gestor 
escolar das escolas públicas da educação básica"; Contribuir com a qualificação do gestor escolar na perspectiva da gestão democrática e da efetivação do direito à educação escolar básica com qualidade social" e também possa "Estimular o desenvolvimento de práticas e gestão democrática e de organização do trabalho pedagógico que contribuam para uma aprendizagem efetiva dos alunos, de modo a incidir, progressivamente, no desempenho escolar". (BRASIL, MEC/DN/PNEGEB, 2009, p.10).

De forma específica, o documento destaca a pretensão de:

- Incentivar os gestores a refletirem sobre a gestão democrática e a desenvolverem práticas colegiadas de gestão, no ambiente escolar, que favoreçam a formação cidadã do estudante;

- Propiciar, aos gestores, oportunidades de lidar com ferramentas tecnológicas, que favorecem o trabalho coletivo e a transparência da gestão da escola;

- Propiciar oportunidades aos gestores para o exercício de práticas inovadoras nos processos de planejamento e avaliação da gestão escolar;

- Possibilitar, aos gestores, oportunidades para ampliação de capacidades para analisar e resolver problemas, elaborar e desenvolver projetos e atividades na área de gestão com o suporte das novas tecnologias de informação e comunicação;

- Desenvolver uma compreensão pedagógica de gestão escolar, situada nos contextos micro e macro da escola, superando as concepções fragmentadas do processo educacional e contemplando as dimensões da construção e formação como objeto do trabalho pedagógico e

- Estimular o desenvolvimento de práticas de gestão democrática e de organização do trabalho pedagógico, que contribuam para uma aprendizagem efetiva dos alunos, de modo a incidir, progressivamente, na melhoria do desempenho escolar. (BRASIL, MEC/DN/PNEGEB, 2009, p. $10)$.

Para a oferta dos cursos, o MEC propõe que eles sejam ofertados por meio de parcerias em regime de colaboração entre as Instituições Públicas de Ensino Superior (IPES) e as secretarias estaduais e municipais. Importante ressaltar que as tentativas desse processo de parceria se estabelecem desde as discussões em torno da elaboração das Diretrizes do PNEGEB, quando há o incentivo e abertura para a participação de entidades sociais, o que se apresenta como positivo considerando os espaços de participação possíveis no governo do presidente Lula, como ponderou Aguiar (2011).

Essa autora argumenta que esse fato se relaciona às características do período do governo Lula que, embora cheio de tensões e condicionantes políticos, foi um momento que propiciou o debate e a participação de várias entidades civis em ações governamentais. A autora lembra que dentre as alterações propostas ao Programa após seu projeto inicial de 2004, teve-se o fato de que a SEB abriu espaço para articulação externa. 
Tomadas essas decisões, a SEB desencadeou o processo de articulação externa mediante contatos com instituições e órgãos da sociedade civil ANPEd, ANDIFES, CNTE, CONSED, UNDIME, UNICEF -, com o propósito de assegurar sustentação política e acadêmica a esse empreendimento. (AGUIAR, 2010, p. 166).

A autora reconhece que, mesmo que os programas governamentais destinados à formação de gestores escolares já tenham suas propostas definidas e operacionalizadas pelos órgãos centrais, no caso do PNEGEB, “considera-se que houve a intervenção de setores da sociedade civil, o que lhe emprestou uma configuração singular no plano das políticas públicas em educação". (AGUIAR, 2011, p.2).

Com relação às parcerias para o funcionamento dos cursos propostos a partir do PNEGEB, os documentos destacam as funções de cada um dos entes envolvidos entre o MEC, os municípios e estados e as Instituições de Ensino Superior - IPES. Em relação ao papel do MEC, por meio da SEB e da Diretoria de Fortalecimento Institucional e Gestão Educacional (DFIGE), é de fornecer suporte pedagógico, técnico e financeiro e também de coordenar e avaliar o desenvolvimento do Programa em âmbito nacional.

O MEC também oferece às IPES os projetos pedagógicos dos cursos, direcionando os objetivos de formação, o perfil esperado, os princípios orientadores do curso, a carga horária e organização curricular e fluxo curricular, bem como fornece o material didático-pedagógico, as orientações metodológicas para funcionamento dos cursos, além de orientar quanto à avaliação da aprendizagem e à operacionalização dos cursos. De acordo com o artigo $5^{\circ}$ da Portaria ministerial n $n^{\circ} 145$ de 2009, o MEC também faz a articulação entre a oferta de cursos e a demanda dos entes federativos.

As IPES são convidadas e selecionadas pelo MEC para participarem do Programa na condição de instituições formadoras. Para participar, precisam apresentar um Plano de Trabalho e o Projeto Pedagógico do Curso de acordo com as necessidades em que ele será ofertado.

Sobre a parceria das IPES, o documento de Diretrizes Nacionais do PNEGEB reconhece que a formação continuada é um dos direitos que os profissionais da educação têm, baseando-se legalmente no artigo 63, inciso III, da LDB 9394/96, a qual determina às instituições formadoras de educação a manter programas de educação continuada para os profissionais da educação dos diversos níveis. Assim, reconhece que as instituições públicas e participantes do PNEGEB devem "criar as condições para sua operacionalização, associada ao exercício profissional na escola, devendo possibilitar atualização, aprofundamento, 
complementação e ampliação de conhecimentos”. (BRASIL, MEC/DN/PNEGEB, 2009, p.12).

Sobre a parceria das secretarias municipais e estaduais, as Diretrizes do PNEGEB não deixam claro quais seriam suas funções, referindo-se apenas na questão do trabalho em regime de colaboração e a adesão dessas secretarias ao Programa, conforme explicitado no $\operatorname{artigo} 4^{\circ}$ da Portaria Ministerial de 2009.

No entanto, no Projeto Pedagógico do Curso de especialização lato sensu proposto pelo MEC no ano de 2009, mais especificamente no anexo 2 desse PPC, encontramos a apresentação de um roteiro de ações e responsabilidades dos parceiros do curso, no qual se percebe que é função das secretarias estaduais e municipais, por meio da UNDIME e SEDUC, a constituição das equipes de coordenação local do curso para promoção da articulação com o MEC, bem como de "fazer a inscrição e pré-seleção dos candidatos/cursistas", divulgar o curso em "impressa ou digital ou online (a critério de cada Estado)"; organizar e divulgar critérios para participação.

O anexo do projeto também aponta, como ações de responsabilidades desses entes, juntamente com as instituições formadoras a "definição de polos presenciais de atendimento"; "constituição das equipes locais de assistência e de apoio técnico"; o auxílio financeiro para deslocamentos aos polos, além de auxiliarem a formação dos cursistas para que esses tivessem acesso e permanência ao ambiente virtual de aprendizagem.

Sobre a questão do auxílio financeiro para a participação dos cursistas nos encontros presenciais, consta no PPC do MEC que "o deslocamento dos cursistas para os polos de apoio presenciais será planejado e custeado pelas secretarias municipais e estadual de cada estado em parceria com a SEB/MEC”. (BRASIL, MEC/PPC-CP, 2009, p.6).

Com relação à modalidade de formação adotada pelo Programa por meio da educação a distância, as Diretrizes Nacionais reconhecem que os cursos de formação devem garantir uma formação "de qualidade socialmente referenciada" (p.8). Assim, apostam na formação continuada a distância, destacando algumas de suas qualidades, dentre elas:

[...] maior flexibilidade na organização e desenvolvimento dos estudos; fortalecimento da autonomia intelectual no processo formativo; acesso às novas tecnologias da informação e comunicação; interiorização dos processos formativos, garantindo o acesso daqueles que atuam em escolas distantes dos grandes centros urbanos; redução dos custos de formação a médio e longo prazo; a interatividade entre os formandos, facilitando o trabalho coletivo; fortalecimento de infraestrutura adequada nas universidades públicas, estimulando a formação de grupos de produção científica na área de gestão escolar, e de formação de quadros para atuarem 
com EAD e sua institucionalização no tocante à formação continuada. (BRASIL, MEC/DN/PNEGEB, 2009, p.8)

Nesse documento de Diretrizes, também é ressaltada a compreensão da educação a distância voltada para a relação dialética entre teoria e a prática, sugerindo que o processo de formação nos cursos ofertados pelo PNEGEB valorize a prática do profissional, ou seja, que ele adquira conhecimento na ação da prática diária de trabalho. O documento reconhece que apenas esse conhecimento não é suficiente, e espera que os processos de formação desse Programa, possam "propiciar o desenvolvimento da capacidade de refletir, oferecendo perspectivas de análise, para que os gestores escolares compreendam os contextos históricos, sociais, culturais, organizacionais e de si próprios como profissionais". (p.12).

De maneira geral o documento aponta mudanças com relação ao Projeto Básico. Um exemplo é sobre a concepção dos gestores escolares, os quais não se resumem apenas aos diretores das escolas, mas também se amplia aos outros cargos da gestão pedagógica, sendo esse profissional considerado como um professor/gestor. "Os processos de formação continuada que caracterizam este Programa são dirigidos aos Professores-Gestores das Escolas Públicas de Educação Básica”. (BRASIL, MEC/DN/PNEGEB, 2009, p.14).

Ao mesmo tempo em que percebemos mudanças, também apreendemos contradições. Há trechos do documento das Diretrizes em que se confunde o Programa, na sua dimensão mais geral, com um curso. Um exemplo está expresso no item 1.1 denominado de "Princípio Norteador do Curso", o que nesse caso pode ter sido um erro de digitação, uma vez que o exposto nesse item não se refere a um curso.

Outro exemplo está no item 1.6 das Diretrizes em que se apresentam as concepções de formação do Programa, mas se discorre a uma concepção de curso: "Conforme se pode inferir dos objetivos do Programa Nacional Escola de Gestores da Educação Básica Pública e dos pressupostos da respectiva estratégia, esta proposta de curso está sustentada em uma concepção de educação como processo construtivo e permanente”. (p.12). (grifos nossos).

No que refere às estratégias de formação para gestores escolares, percebemos que as Diretrizes, na perspectiva da POD, declaram que o PNEGEB "integra um conjunto de estratégias, voltadas à formação de gestores escolares", dentre elas destaca-se o curso Piloto em Gestão Escolar de 100h (2005), o Curso de Atualização em Gestão Escolar de 180h que seria implementado em 2009 e o Curso de Pós-Graduação lato sensu em Gestão Escolar de 400h, implementado a partir de 2006/2007.

No entanto, não conseguimos identificar, nessas estratégias, a proposta para o curso de especialização lato sensu em Coordenação Pedagógica, embora o MEC tenha elaborado o 
PPC desse curso também no ano de 2009, mesmo ano em que as Diretrizes do Programa foram aprovadas. Buscando entender os motivos desse curso não ter sido apontando dentre as suas estratégias, buscamos informações no portal do MEC, no espaço "Histórico/Escola de Gestores", mas encontramos apenas o registro de funcionamento dos cursos:

O Programa Nacional Escola de Gestores da Educação Básica integra um conjunto de ações que teve início, em 2005, com o curso-piloto de extensão em gestão escolar (100 horas), ofertado pelo Inep. [...] Em 2006, o programa passou a ser coordenado pela SEB/MEC, dando início ao Curso de Pósgraduação (lato sensu) em Gestão Escolar, com carga horária de 400 horas, destinado a diretores e vice-diretores, em exercício, de escola pública da educação básica. Em 2009, o programa implementou o Curso de PósGraduação Lato sensu em Coordenação Pedagógica, carga horária de 405 horas, para coordenadores pedagógicos elou profissionais que exercem função equivalente que integram a equipe gestora da escola de educação básica. E em 2010, lançou o Curso de Aperfeiçoamento em Gestão Escolar, com carga horária de 200 horas, este curso destina-se aos profissionais de instituições públicas de educação básica da equipe gestora: Diretor e ViceDiretor, ou o equivalente, nos diferentes sistemas de ensino. Hoje, os cursos estão sendo operados sob a responsabilidade de 31 IPES, atendendo a totalidade dos estados e do Distrito Federal. (PORTAL MEC, HISTORICO/ESCOLA DE GESTORES).

$\mathrm{Na}$ pesquisa de doutorado de Fernandes (2015), ela pontua que a instituição desse curso se refere a um dos mecanismos encontrados pelo MEC para se alcançar a meta proposta nas Diretrizes do Programa, que era de "atingir, até 2011, cerca de 35.000 (trinta e cinco mil) gestores da Educação Básica, que atuam nas redes públicas”. (BRASIL, MEC/DN/PNEGEB, 2009, p.11).

A autora, ao analisar sobre as metas de formação de gestores, conforme anunciado no documento de Diretrizes, sinaliza que o curso de Coordenação Pedagógica surge como uma alternativa para o MEC alcançar essa meta estabelecida, já que, apenas pelo curso de gestão escolar, não seria possível.

No que se refere ao alcance de tais metas, a coordenação nacional do Programa fez um levantamento e constatou que, no período de 2006 a 2008, o Curso de Especialização em Gestão Escolar beneficiou 11.095 gestores em todo o país, número ainda distante da meta, provavelmente inicial, de 174.800. Para alcançar outros profissionais da gestão escolar, em 2009, o programa foi ampliado aos coordenadores pedagógicos ou funções equivalentes com a implantação do curso de especialização em Coordenação Pedagógica. Com isso, houve um aumento significativo de beneficiados, sendo 9.09022 gestores em formação nos Cursos de Especialização em Gestão Escolar e em Coordenação Pedagógica, [...] Para 2010, a SEB/MEC autorizou a oferta de 7.86023 novas vagas nos dois cursos já referidos e iniciou o curso de aperfeiçoamento em Gestão do IDEB Escolar (180 horas), 
direcionado, prioritariamente, a atender aos gestores das escolas que se apresentam abaixo da média nacional. (FERNANDES, 2015, p. 67).

Outra percepção acerca das análises desses documentos tem a ver com a ênfase ao processo de desenvolvimento das parcerias para que o Programa fosse implementado nos Estados brasileiros. Em posição de inquirição, indagamos se essas parcerias de fato ocorrem, se os parceiros envolvidos entendem e desenvolvem suas funções? Questionamos acerca do regime de colaboração pretendido, pois será que existe esse regime entre os entes federados? Questionamos sobre qual a concepção de educação e de formação que esses parceiros possuem e como as materializam nas ações dos cursos do PNEGEB?

Não há dúvida de que, nos estados brasileiros, representados pelas escolas públicas estaduais e municipais, há uma demanda urgente por formação de professores/gestores, tanto para que eles se tornem profissionais melhores, quanto para que produzam mudanças nas ações no seu dia a dia de trabalho e possam contribuir com a melhoria da qualidade educacional do país. No entanto, questionamos sobre a ênfase do Programa em contribuir com a formação de profissionais para a melhoria na qualidade dos processos de gestão da escola, a partir do contexto em que ele se situa a partir do PDE e do Plano de Metas Compromisso Todos Pela Educação, que, por sua vez, está atrelando aos instrumentos de regulação como o IDEB.

Várias são as percepções por meio das análises dos documentos de criação e implantação do PNEGEB no Brasil, as quais, ora se apresentam a partir da perspectiva da Política Oficialmente Declarada - POD e ora na perspectiva da Política de Fato - POF. Como estamos estudando uma política que é social, histórica e constituída por seres humanos, sabemos que ela está repleta de contradições e são elas que nos fazem continuar os estudos.

Conhecidas as origens do Programa Nacional, bem como algumas de suas principais características, no próximo tópico apresentamos a proposta do curso de especialização em Coordenação Pedagógica desenvolvida pela UFT e seus parceiros no Tocantins no período de 2010 a 2011, a fim de melhor compreendermos sua dinâmica no contexto do PNEGEB.

\subsection{O PNEGEB no Tocantins a partir da Especialização para Coordenadores Pedagógicos}

No estado do Tocantins, a presença do PNEGEB é marcada, desde o ano de 2005, com a oferta do Programa Piloto sob a coordenação do Inep e em parceria com a Universidade 
Federal do Tocantins (UFT), as secretarias municipais e estaduais. Até o ano de 2016, foram ofertados quatro cursos de especialização lato sensu sendo dois voltados para a Gestão Escolar e dois para a Coordenação Pedagógica o que supõe a oferta de quase 2000 vagas para formação de professores/gestores.

Dentre essas experiências do PNEGEB no Tocantins, tomamos como recorte para o estudo nesta tese, o curso de especialização lato sensu em Coordenação Pedagógica cujas atividades pedagógicas tiveram início em dezembro de 2010 sendo finalizadas em dezembro de 2011. No entanto, como destaca o Plano de Trabalho Anual (PTA) da UFT, o processo de tramitação dos projetos para apreciação na UFT e no MEC iniciou-se em julho de 2009, com previsão de que o curso iniciasse em dezembro do mesmo ano.

Esse processo de tramitação do curso foi considerado complicado e muito demorado pela coordenação geral do curso, tanto referente às ações do âmbito do MEC, quanto internamente pela própria instituição formadora. O Relatório Final do Curso apresenta o extrato do Fórum de uma Sala Ambiente da coordenação denominada de "Colegiado do Curso", em que o coordenador geral relata esses problemas.

No Fórum intitulado de "A burocracia é mais importante" percebemos o desabado do coordenador que inicia a discussão com a seguinte frase: "veja com quantos processos se faz uma burocracia..." e na sequência informa que a UFT foi convidada em julho de 2009 a ofertar o curso e, desde então, foi realizado um esforço para elaboração e tramitação dos documentos necessários à aprovação dos projetos.

Da parte do MEC, embora o PTA da UFT tivesse sido aprovado, o curso não pôde iniciar, pois a equipe de produção do material pedagógico não havia entregado a plataforma com todos os conteúdos disponíveis. No que se refere à UFT, o coordenador relata que houve vários problemas burocráticos com relação ao encaminhamento do PPC, o qual deveria passar pelas instâncias de aprovação de um curso de graduação e ser encaminhado para a reitoria da Universidade para sua aprovação nas instâncias superiores. Esse processo interno, portanto, foi muito complicado.

Importante ressaltar que as entidades civis, como a ANDIFES e a ANPED, que participaram da discussão para a elaboração das Diretrizes do PNEGEB e do Projeto Pedagógico do Curso de Especialização em Gestão Escolar, como destacado por Aguiar (2010), orientaram que os cursos de pós-graduação ofertados por esse Programa fossem vinculados aos núcleos de educação que desenvolvessem estudos em política e gestão da educação. 
No entanto, a UFT foge a essas orientações. Todos os cursos ofertados pelo PNEGEB por meio dessa instituição foram iniciativas de um grupo de professores com experiência em EaD, ligados ao Centro de Tecnologia Educação (CTE) e que, não especificamente, eram da área da gestão escolar. Na estrutura da UFT, não há faculdades ou departamentos de educação e os cursos de pedagogia e licenciaturas são ofertados em vários campi da Universidade.

Assim, o CTE, atualmente denominado de Diretoria de Tecnologias Educacionais (DTE), assumiu a condução do curso de especialização tendo em vista as experiências com curso na modalidade a distância. Para atender as normas internas da pós-graduação na instituição, a coordenação geral do curso de Coordenadores precisava aprovar o PPC em um dos cursos de graduação em que tinham professores/representantes e envolvidos na gestão do curso.

Assim, como relata o coordenador no extrato do Fórum do Colegiado, destacado no Relatório Final do Curso, houve três tentativas de aprovação do PPC, sendo um no curso de Pedagogia do campus de Miracema, outro no curso de Comunicação Social e, por fim, no curso de Pedagogia do campus de Arraias que foi aprovado, mas ocorreram problemas de encaminhamento da documentação para reitoria, demorando algum tempo para ser finalizado.

Como o PTA havia sido aprovado pelo MEC para a descentralização do recurso financeiro, o que havia sido pensado e planejado pela coordenação teve que ser novamente reestruturado.

As discussões para execução do curso, elaboração do PTA e do PPC ocorreram na Sala Ambiente "Espaço do Colegiado" no AVA moodle e contou com a participação dos coordenadores e de alguns professores do curso de Gestão Escolar que estava em fase de encerramento. Também teve a participação da secretária executiva da União Nacional dos Dirigentes Municipais de Educação (Undime - TO) e da diretora de formação continuada da Secretaria Estadual de Educação do Tocantins (Seduc-TO). (UFT, RELATÓRIO DO CURSO, 2012).

Conforme destaca o Relatório Final do Curso, as discussões e justificativas do grupo para a implantação do curso também levaram em consideração um estudo realizado pela Seduc-TO sobre a demanda de interesse para formação de coordenadores pedagógicos e profissionais afins, como percebemos pela Figura 1, a qual sinaliza a maior demanda nas regiões centro oeste, norte e sul do Estado. 
Figura 1 - Demanda de formação de coordenadores Seduc-TO

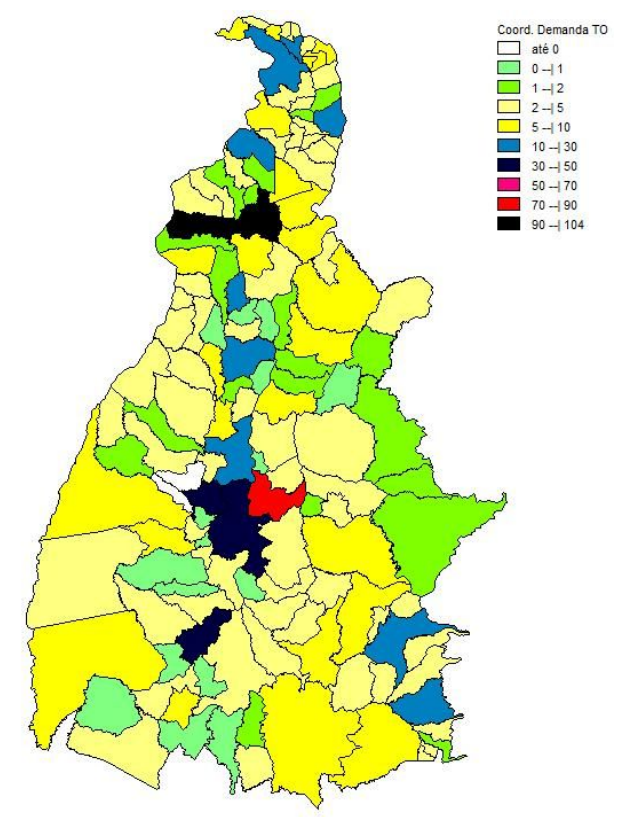

Fonte: SEDUC-TO/MEC - Relatório Final do Curso

A partir da demanda para a oferta do curso no Tocantins, das discussões, da elaboração do PPC e PTA na UFT, as atividades pedagógicas foram então iniciadas em dezembro de 2010. Foram disponibilizadas 400 vagas, sendo 200 para atender os profissionais das escolas do Município e 200 vagas para escolas do Estado, de acordo com a demanda sendo distribuídas em 10 polos no Estado e subdivididas por turmas, conforme melhor visualizamos pela Figura2.

Figura 2 - Distribuição de vagas

\begin{tabular}{|c|c|c|}
\hline Polos & Turmas & Vagas \\
\hline Araguaína & 2 & 80 \\
\hline Arraias & 1 & 40 \\
\hline Gurupi & 1 & 40 \\
\hline Guaraí & 1 & 40 \\
\hline Palmas & 3 & 120 \\
\hline Porto Nacional & 1 & 40 \\
\hline Tocantinópolis & 1 & 40 \\
\hline Total & 10 & 400 \\
\hline
\end{tabular}

FONTE: Relatório do Curso - Coordenação Pedagógica, UFT, 2012.

Os profissionais que podiam concorrer às vagas eram os coordenadores pedagógicos, profissionais do suporte pedagógico da rede estadual de educação elou aqueles que exerciam 
função equivalente e integravam a equipe gestora da escola, os quais podiam ser em número de até dois profissionais de cada escola, considerando as prioridades estabelecidas no PPC da UFT conforme o Ofício/GAB/DFIGE/MEC n 91 de 27 de outubro de 2009.

$\left.1^{\circ}\right)$ Escolas prioritárias - baixo IDEB;

$2^{\circ}$ ) Municípios que demandaram esta formação no PAR;

$3^{\circ}$ ) Municípios que elaboraram PAR, mas não apresentaram demanda para esta formação. (UFT/PPC, 2010, p. 3).

Mesmo com o processo em tramitação, a coordenação resolveu fazer a seleção dos participantes. Assim, o processo seletivo iniciou em agosto de 2010 e foi encerrado em novembro de 2010, tendo sido realizado em três meses, após tentativas para o preenchimento de todas as vagas nas turmas do curso. O Relatório Final do Curso aponta que foram elaborados cinco editais para tentar sanar os problemas encontrados durante a seleção.

Conforme primeiro Edital de seleção $n^{\circ}$ 01/2010 da PROPESQ/CTE ${ }^{10} /$ UFT, para se inscrever o candidato deveria preencher uma ficha on-line por meio de formulário disponibilizado no site da UFT, realizar o pagamento de uma taxa de inscrição no valor de R\$ 25,00 e enviar cópia dessa ficha impressa e assinada, do comprovante de pagamento, bem como a cópia dos documentos exigidos conforme o edital, sendo o envio por meio de Correios ou com a possibilidade de serem entregues pessoalmente ou por pessoa autorizada.

Dentre os documentos exigidos, os candidatos deveriam encaminhar documento oficial que declarava o exercício da sua função de coordenador pedagógico ou de função equivalente, um Termo de Compromisso sobre as exigências do curso, bem como, deveriam enviar um Memorial Descritivo que justificava o interesse do candidato, mostrando sua trajetória de formação e também um Projeto de Intervenção sobre as possíveis ações a serem desenvolvidas nas escolas onde o candidato trabalhava. Para todos esses documentos, o edital disponibilizava modelos em anexo.

Por meio desse Edital, o processo seletivo ocorreria em etapa única "mediante análise da documentação exigida, ou seja, do Plano de Intervenção, Memorial Descritivo e atendendo aos requisitos mínimos". (UFT/EDITAL, 01/ 2010). Ocorre que, como ressaltado no Relatório Final do Curso, esse processo não foi positivo e a coordenação encontrou vários problemas para preencher as vagas, embora tivesse mais inscritos do que vagas, seja porque muitos candidatos não entregaram a documentação ou porque muitos não atendiam aos requisitos.

\footnotetext{
${ }^{10}$ PROPESQ refere-se a Pró-Reitoria de Pesquisa da UFT e CTE ao Centro de Tecnologias Educacionais.
} 
Tivemos um problema que complicou bastante o processo que foi o fato de muitos não entregar a documentação. Foram 742 inscrições, porém com a análise do banco de dados identificamos sendo que 154 incrições não atendiam aos criterios do curso porque muitos não atuavam em escola pública, não atuava na coordenação, não tinham curso superior completo. Das 588 inscrições restantes 279 já haviam cursado outra especilização e, portanto não eram prioridades. Do primeiro edital tivemos apenas 502 inscrições com a documentação completa para a conferência dos documentos. (UFT, RELATÓRIO CURSO CP, 2012, p. 6).

O Relatório destaca que, diante desses acontecimentos, a coordenação considerou a possibilidade de prorrogação dos prazos, tendo em vista o preenchimento das vagas: “Após o início da análise aplicando todos os critérios do Programa, vimos que haveria uma redução muito grande para atender apenas aos que estivessem rigorosamente dentro dos critérios". Assim, foram divulgados outros cinco editais com a prorrogação das inscrições, sendo possível a divulgação da lista completa dos inscritos no último Edital de ${ }^{\circ} 6$.

Por meio do primeiro edital, o total de vagas não foi preenchido em todos os polos. Vale ressaltar que nele havia um item que previa que: "As vagas não preenchidas, [...] poderão ser preenchidas por candidatos aprovados no processo de seleção em lista de espera em outros polos, a critério da coordenação do curso até o preenchimento total das vagas". Assim, foram abertos os outros editais prorrogando as datas de inscrições ao curso.

No Edital de $n^{0} 5$, destaca-se que a coordenação disponibilizou as vagas remanescentes aos parceiros para que eles providenciassem diretamente o preenchimento das vagas, ressaltando que:

1. Em continuidade ao processo seletivo, divulga-se a lista de classificados e encaminhamentos a outras providências.

2. A coordenação do curso apresenta o anexo da lista de classificados e esclarece que:

2.1 Considerando que muitos inscritos não cumpriram os requisitos estabelecidos no Edital $n^{\circ} 01 / 2010$ do Processo de Seleção, as vagas remanescentes serão disponibilizadas aos parceiros articuladores (SEDUC e UNDIME);

2.2 Os novos candidatos serão submetidos às mesmas regras do Edita101/2010. (UFT, EDITAL 05/2010).

Assim, as turmas foram preenchidas e organizadas por municípios conforme observamos na Figura 3. Disponibilizaram-se quatro turmas para a região Norte, sendo uma em Tocantinópolis, duas em Araguaína e uma em Guaraí. Quatro turmas para a região Central do Estado, sendo três em Palmas e uma em Porto Nacional e ainda duas turmas para a região 
Sul, sendo uma em Gurupi e uma em Arraias, de forma a atender as demandas de formação expressas no Estado.

Figura 3 - Turmas por polos

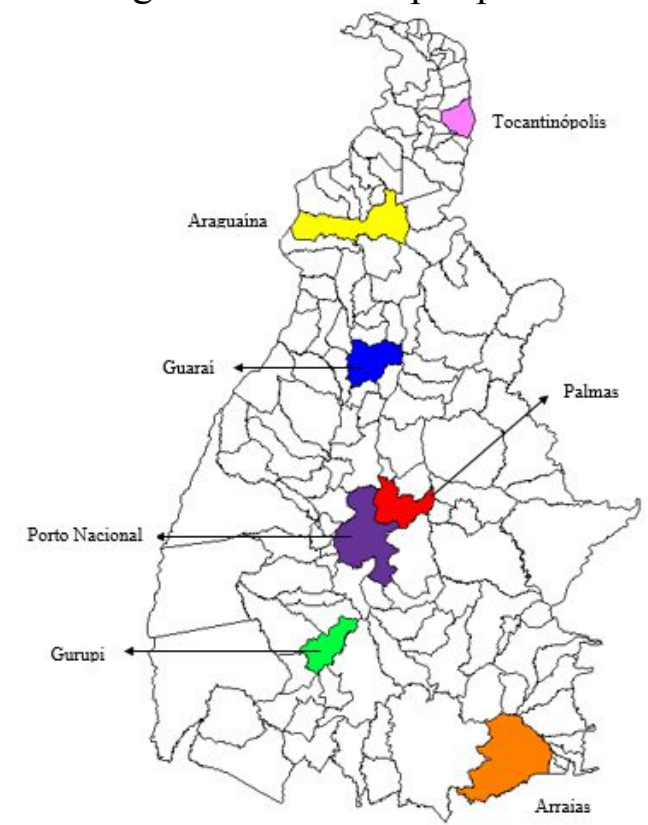

FONTE: Relatório do Curso - Coordenação Pedagógica, UFT, 2012.

Para organização das turmas, o Relatório Final do Curso aponta que foi considerada a localização geográfica das escolas, a proximidade entre os municípios, o acesso à cidade do polo presencial e, também, a disponibilidade de vagas. Em relação aos resultados quantitativos da formação, o Relatório destaca que o curso conseguiu atender à demanda de formação de mais de 97 (noventa e sete) municípios, sendo o número de evasão considerado baixo, pois dentre os 400 cursistas que ingressaram, obteve-se mais de $75 \%$ de êxito, apesar de que, no PPC da UFT, tinha-se o desejo de não se ultrapassar os $20 \%$ de evadidos.

Com relação ao desenvolvimento operacional do curso, observamos pelo PPC da UFT que algumas ações e propostas foram modificadas em relação ao PPC do MEC, no entanto a maior parte do projeto se apresenta igual, por exemplo, os objetivos gerais e específicos do curso permaneceram os mesmos propostos no PPC do MEC, as metas, o perfil esperado, a concepção de formação, os princípios orientadores, a organização curricular e material didático, carga horária, dentre outros elementos.

A oferta do curso pela UFT foi organizada para ser desenvolvida no ambiente virtual de aprendizagem (AVA) moodle, sendo as disciplinas ou componentes curriculares 
disponibilizadas nas chamadas Salas Ambientes ${ }^{11}$. O PPC da UFT é enfático ao justificar e concordar com a dinâmica das salas ambientes:

A concepção do curso em salas ambientes possibilita oferecer o curso com as atividades curriculares distribuídas em rede ao longo do curso sem a necessidade da estratégia tradicional de oferta em disciplinas ou módulos. Dessa forma, todas as salas ambientes estarão abertas durante o curso, mas as atividades nas salas serão descontinuadas conforme a organização que as exigirem. (PPC/UFT, 2010, p.12).

Apreendemos que a matriz curricular foi organizada em torno do eixo da Organização do Trabalho Pedagógico, conforme previsto pelo PPC do MEC, na qual considera as temáticas relacionadas aos dois níveis abrangentes do trabalho do coordenador que são o espaço da escola em geral e o espaço da sala de aula:

A opção por essa denominação para o eixo integrador do curso justifica-se pelo fato de que ela sintetiza a dupla abrangência da função de Coordenação Pedagógica numa instituição educacional: o âmbito da escola compreendida como local social de formação crítica e cidadã e o âmbito da sala de aula, espaço em que a prática educativa acontece de forma planejada e intencional. (BRASIL, MEC/PPC, 2009, p. 11).

A partir desse eixo central, o curso foi organizado em nove Salas Ambientes, sendo oito salas temáticas e uma de Introdução ao Ambiente Virtual moodle. Considerando o curso com carga horária de $405 \mathrm{~h}$, a sugestão do fluxo curricular do MEC era de que as Salas Ambientes disponibilizassem os conteúdos teóricos e atividades da seguinte maneira: Salas Ambientes: Introdução ao moodle - (15horas); Realidade Escolar e Trabalho Pedagógico - (30 horas); Projeto Político-Pedagógico e Organização do Ensino - (45 horas); Currículo, Cultura e Conhecimento Escolar - (45 horas); Avaliação Escolar - (45 horas); Práticas e Espaços de Comunicação na Escola - (45 horas); Aprendizagem Escolar e Trabalho Pedagógico - (45 horas); Políticas Educacionais e Gestão Pedagógica - (45 horas); Tópico Especial -(45 horas) e a Sala Ambiente - Metodologia do Trabalho Científico - MTC (45 horas). (BRASIL, MEC/PPC, 2009, p.12-13).

O PPC da UFT considerou essas orientações do MEC, mas a Sala Ambiente Tópicos Especiais de $45 \mathrm{~h}$ não foi ofertada, sendo sua carga horária inserida à da Sala de Trabalho Científico, que ao invés de MTC, foi chamada de "Sala Projeto de Intervenção e TCC" passando a somar 90h. Essa sala foi desenvolvida ao longo de todo o curso, conforme

\footnotetext{
${ }^{11}$ Salas Ambientes referem-se aos espaços virtuais em que o material didático e pedagógico era disponibilizado, como as unidades curriculares, os textos e as atividades e, ainda, local em que ocorria o processo de interação e aprendizagem virtual.
} 
observamos pela Figura 4 e não como a sugestão do MEC que seria iniciada só após a Sala Projeto Político Pedagógico e Organização do Ensino.

Figura 4 - Distribuição das componentes curriculares por carga horária.

\begin{tabular}{|c|c|c|c|c|c|}
\hline $\begin{array}{l}\text { Salas Ambientes } \\
\text { (Componentes curriculares) }\end{array}$ & \multicolumn{3}{|c|}{ Carga Horária } & $\begin{array}{l}\text { Duração } \\
\text { Minima }\end{array}$ & Fases \\
\hline $\begin{array}{l}\text { Introdução ao Curso e ao Ambiente } \\
\text { Virtual }\end{array}$ & $15 \mathrm{hs}$ & \multirow{3}{*}{$\begin{array}{l}30 \mathrm{hs} \\
\text { TCC }\end{array}$} & \multirow{3}{*}{$\begin{array}{l}120 \\
\text { hs }\end{array}$} & $\begin{array}{c}7 \\
\text { semanas }\end{array}$ & \multirow{3}{*}{$\begin{array}{l}1^{\mathrm{a}} \mathrm{FASE} \\
2 \text { Encontros } \\
\text { Presenciais }\end{array}$} \\
\hline $\begin{array}{l}\text { Realidade Escolar e Trabalho } \\
\text { Pedagógico }\end{array}$ & $30 \mathrm{hs}$ & & & \multirow{2}{*}{$\begin{array}{c}9 \\
\text { semanas }\end{array}$} & \\
\hline $\begin{array}{l}\text { Projeto Político Pedagógico e } \\
\text { Organização do Ensino }\end{array}$ & 45 hs & & & & \\
\hline $\begin{array}{l}\text { Currículo, Cultura e Conhecimento } \\
\text { Escolar }\end{array}$ & 45 hs & \multirow{4}{*}{$\begin{array}{l}20 \mathrm{hs} \\
\text { TCC }\end{array}$} & \multirow{4}{*}{$\begin{array}{l}200 \\
\text { hs }\end{array}$} & $\begin{array}{c}12 \\
\text { semanas }\end{array}$ & \multirow{4}{*}{$\begin{array}{l}2^{\mathrm{a}} \mathrm{FASE} \\
3 \text { Encontros } \\
\text { Presenciais }\end{array}$} \\
\hline Avaliação Escolar & $45 \mathrm{hs}$ & & & \multirow{3}{*}{$\begin{array}{c}12 \\
\text { semanas }\end{array}$} & \\
\hline Aprendizagem e Trabalho Pedagógico & $45 \mathrm{hs}$ & & & & \\
\hline $\begin{array}{l}\text { Práticas e Espaços de Comunicação } \\
\text { na Escola }\end{array}$ & 45 hs & & & & \\
\hline $\begin{array}{l}\text { Politicas Educacionais e Gestão } \\
\text { Pedagógica }\end{array}$ & 45 hs & \multirow{2}{*}{$\begin{array}{l}40 \mathrm{hs} \\
\text { TCC }\end{array}$} & \multirow{2}{*}{85 hs } & \multirow{2}{*}{$\begin{array}{c}8 \\
\text { semanas }\end{array}$} & \multirow{2}{*}{$\begin{array}{l}3^{\text {a }} \text { FASE } \\
1 \text { Encontro } \\
\text { Presencial }\end{array}$} \\
\hline Trabalho de conclusão de curso & $90 \mathrm{hs}$ & & & & \\
\hline Carga horária total & \multicolumn{3}{|c|}{405 hs } & $\begin{array}{c}48 \\
\text { semanas }\end{array}$ & 12 meses \\
\hline
\end{tabular}

FONTE: UFT/PPC, 2010, p.21.

Com relação aos encontros presenciais, a orientação do MEC era que fossem organizados, no mínimo, três e, de acordo com planejamento prévio dos parceiros, os cursistas contariam com o apoio das secretarias municipais e estaduais para custear as viagens aos polos. "O deslocamento dos cursistas para os polos de apoio presenciais será planejado e custeado pelas secretarias municipais e estadual de cada estado em parceria com a SEB/MEC".

No entanto, essa diretriz se coloca na perspectiva da Política Oficialmente Declarada POD, pois como fica evidenciado nos Relatórios do curso e como veremos nas análises dos dados empíricos, o apoio institucional dos parceiros para custeamento das viagens dos cursistas aos polos não foi totalmente realizado.

Sobre o quantitativo dos encontros presenciais, a UFT optou pela realização de seis encontros presenciais, sendo um a cada dois meses, considerando os 12 meses do curso, os quais foram intercalados nas três fases de desenvolvimento como observamos na Figura 4.

Em relação ao material didático para cursos na modalidade a distância, se considerarmos o Documento "Referenciais de Qualidade para Educação Superior a Distância" elaborado pela Seed/MEC em 2007, apreendemos que, para os projetos de curso a distância, 
as orientações são para que a equipe de produção dos materiais trabalhe de forma multidisciplinar e que atendam às concepções de educação desejadas de forma a tornar explícitas as concepções de formação.

[...] é recomendável que as instituições elaborem seus materiais para uso a distância, buscando integrar as diferentes mídias, explorando a convergência e integração entre materiais impressos, radiofônicos, televisivos, de informática, de videoconferências e teleconferências, dentre outros, sempre na perspectiva da construção do conhecimento e favorecendo a interação entre os múltiplos atores. (MEC, REFERENCIAIS DE QUALIDADE EAD, 2007).

O Referencial orienta que, em cursos ofertados nessa modalidade, seja disponibilizado um conjunto de materiais didáticos que permitam o melhor desenvolvimento cognitivo dos alunos, entre eles: material impresso, vídeos, programas televisivos e radiofônicos, videoconferências, CD-Rom, páginas WEB, objetos de aprendizagem entre outros.

No caso do curso em análise, não identificamos, nos documentos oficiais, a referência aos materiais didáticos utilizados, e sim aos conteúdos, dentre eles o material teórico de estudo composto por textos, links para vídeos, referências bibliográficas complementares e as atividades do curso. Embora o PPC do MEC indicasse que seria ofertado CD-Rom para os alunos, não encontramos essa afirmação em nenhum documento da UFT.

O conteúdo teórico foi elaborado por professores de várias universidades, como passaremos a detalhar a seguir e, no caso da UFT, vemos que ela utilizou o conteúdo dos textos e referenciais de acordo com as orientações do $\mathrm{MEC}$, no entanto, com relação às atividades, veremos que elas foram reformuladas.

Consta nos créditos gerais de cada Sala Ambiente os nomes dos professores da equipe de produção do material teórico do curso, como passamos a descrever a seguir. A Sala "Introdução ao Ambiente Virtual" foi elaborada por Sônia Schechtman Sette, Cristina Teixeira Vieira de Melo, Maria de Fátima Duarte Angeiras, Eduardo José Soares Dias da Silva, Maria Cleoneide Adolfo Brito, Suzana de Andrade Ferreira, Bruno Rafael Torres Ferreira e Michele Ramos Valongo, sendo todos da Universidade Federal de Pernambuco (UFPE).

A Sala "Aprendizagem e Trabalho Pedagógico" também foi elaborada por autores dessa universidade, sendo eles: Ester Calland de Sousa Rosa, Tacyana Carla Ramos, e Hurika Andrade. A Universidade Federal de Santa Catarina (UFSC) por meio das autoras Leda 
Sheibe e Ticiane Bombassaro, elaborou o material para a Sala "Currículo, Cultura e Conhecimento Escolar".

A Sala Ambiente "Projeto Pedagógico e a Organização do Ensino" foi elaborada pela autora Marta Leandro da Silva da Universidade Federal de Uberlândia (UFU) em colaboração com Mirza Seabra Toschi, Eliane Anderi e Renato Ribeiro Leite da Universidade Estadual de Goiás (UEG). A UFU também elaborou o material da Sala "Metodologia da Pesquisa Científica” por meio da autora Marisa Lomônaco de Paula Naves.

A Universidade Federal de Sergipe (UFS) também elaborou material para a Sala "Práticas e Espaços de Comunicação na Escola" por meio do autor José Mário Aleluia Oliveira. A Universidade de São Paulo (USP) elaborou material para a Sala "Avaliação Escolar" por meio da autora Sandra Zákia Sousa.

A Sala de "Politicas Educacionais e Gestão Pedagógica" foi elaborada pela Universidade Federal do Rio Grande do Norte (UFRN) por meio do autor Antônio Lisboa Leitão de Souza e, por fim, a Sala Ambiente “Realidade Escolar e Trabalho Pedagógico” foi elaborada pela autora Eliza Bartolozzi Ferreira, da Universidade Federal do Espírito Santo (UFES).

Com relação à percepção de avaliação da aprendizagem, o PPC do MEC é enfático em afirmar que os cursos para a formação de Coordenadores Pedagógicos devem priorizar a relação de interação entre os professores e alunos de forma a propiciar uma avaliação processual e formativa.

Esse Projeto Pedagógico também sinaliza que a avaliação deve considerar os objetivos de cada componente curricular e podem ser desenvolvida a partir das propostas das instituições formadoras: "cada sala ambiente apresentará um rol de atividades obrigatórias a serem desenvolvidas a distância. No entanto, outras atividades avaliativas poderão ser propostas pelas IFES e desenvolvidas, inclusive, nos momentos dos encontros presenciais". (PPC/MEC, 2009, p. 15).

Considerando o PPC da UFT e o Relatório Final do Curso, vemos que a coordenação reorganizou as atividades nas Salas Ambientes, não considerando a proposta estabelecida pelo MEC. Assim, no curso da UFT, cada Sala ficou organizada com um quantitativo de até três atividades e um fórum avaliativo.

O Relatório aponta que a coordenação do curso considerou absurda a quantidade excessiva de mais de 134 atividades, bem como o formato das atividades que deveriam ser 
desenvolvidas ao longo do curso, considerando a proposta original do Projeto Pedagógico do MEC.

O curso original tinha 98 atividades distribuídas em 34 Base de dados, 1 Chat, 33 Fóruns, 1 Glossário, 2 Questionários, 25 Tarefas, 2 Wikis. Somando-se as atividades das salas de Tópicos Especiais, havia 11 Base de dados, 1 Chat, 11 Fóruns, 1 Questionário, 11 Tarefas e 1 Wiki. Isso daria um total de 134 atividades para um curso de formação em serviço para serem realizada em 12 meses. O que foi considerado absurdo pela equipe pedagógica e fora decidido que cada sala ambiente teria no máximo 3 atividades, aproximadamente ao que se usa nos cursos presenciais e um fórum de estudos com participação obrigatória. (UFT, RELATÓRIO CURSO/CP, 2012, p.27).

Como atividade avaliativa, o projeto do MEC também ressalta sobre o desenvolvimento do Trabalho de Conclusão do Curso (TCC), pontuando que ele deveria ser desenvolvido pelo cursista ao longo do desenvolvimento do curso e receber orientações de um professor com titulação de mestrado ou doutorado. Assim, destaca o documento:

O TCC será concretizado na elaboração de um estudo que culmine em uma proposta de ação que articule a organização do trabalho pedagógico e a busca de um ensino-aprendizagem de qualidade na escola de educação básica onde atua o cursista. Essa proposta de ação procurará, dentre outros aspectos, consolidar os fundamentos teórico-práticos desenvolvidos ao longo do curso por meio dos conteúdos e atividades das salas ambientes. O formato do TCC deverá atender aos critérios elou requisitos definidos pelas IES. (BRASIL, MEC/PPC, 2009, p.15).

A proposta da UFT, embora tenha considerado essas diretrizes, reformulou a Sala Ambiente sobre Metodologia do Trabalho Científico incluindo horas de trabalho, discussões e orientações para o TCC que, segundo a proposta inicial, seria a de produzir um artigo científico a partir do trabalho de intervenção desenvolvido por meio da metodologia da pesquisa-ação.

No entanto, o Relatório de Avaliação do Curso ressalta que essa questão foi complicada ao longo do curso e, pelo o que a coordenação avaliou da experiência do curso de especialização em Gestão Escolar, a grande maioria dos alunos tiveram dificuldades de elaborar o TCC em forma de artigo e, portanto, fazem alterações e solicitam que o TCC poderia ser expresso em forma de Relatório Analítico, mesmo assim, os cursistas encontram dificuldades na sua realização, como destaca o Relatório do Curso:

[...] a coordenação do curso, juntamente com a coordenação pedagógica e avaliadora, após discussões, encaminharam a decisão de que o TCC seria apresentado em forma de um relatório analítico e também definiram que, os 
trabalhos só seriam realizados individualmente para não contrariar normativa interna da UFT, sobre TCCs de cursos de pós-graduação. Com efeito, como se pode constatar nos memoriais reflexivos e avaliação do curso, essas decisões afetaram em parte muitos cursistas, mesmo tendo significado um trabalho menos exigente quanto o artigo". (UFT, RELATORIO DE AVALIAÇÃO/CP, 2012, p.42).

No que se refere à avaliação do curso, o PPC do MEC não deixa claro como seria realizado e, além disso, apresenta informações que se contradizem, pois destaca sobre o acompanhamento e monitoramento do curso e aponta sobre a avaliação do Programa, informando que ela seria feita pela coordenação geral, de forma a tomar medidas necessárias para o melhoramento do PNEGEB.

Na UFT a coordenação geral do curso previu no seu PTA a contratação de um professor específico para desenvolver um projeto de avaliação do curso no âmbito da experiência no Tocantins. Esse projeto visava estabelecer um processo de avaliação tanto da aprendizagem quanto do curso de forma processual e dialógica, como aponta o Relatório de Avaliação “concebe a avaliação como uma prática contínua e permanente que se configura em um processo de aperfeiçoamento do sistema de gestão e do sistema pedagógico para assim produzir possibilidades de correções na direção da melhoria e da qualidade na oferta do curso". (2012, p.4).

Como melhor compreenderemos no próximo capítulo, os instrumentos para acompanhamento da avaliação da aprendizagem e do curso, propostos pelo projeto de avaliação e utilizados nessa experiência em análise, foram vários e diversificados, dentre eles: o Registro de Acesso do cursista no Ambiente de aprendizagem; o Acompanhamento das Atividades (Tarefas e Fóruns) em cada Sala Ambiente; os Fóruns; os Memoriais Reflexivos; os Encontros Presenciais; a Avaliação Presencial; o Acompanhamento das Propostas de Intervenção de cada cursista e o Acompanhamento dos trabalhos de Conclusão de Curso.

A importância desses instrumentos, como destaca o Relatório de Avaliação do Curso, estava na "possibilidade proporcionada pelo processo de acompanhamento diário, semanal e quinzenal que deveria ocorrer ao longo de todo o desenvolvimento do curso" (p.9), o que permitiria a compreensão do relacionamento e interação entre os envolvidos no curso, evidenciando o acesso e ausência dos cursistas, entre outras questões.

Ainda a título de informações sobre o desenvolvimento do curso pela UFT, é importante ressaltar a concepção de EaD que fica expressa pelos documentos oficiais. Para o MEC ela é uma opção importante considerando o fato de haver um elevado número de profissionais que 
exercem a função de coordenadores pedagógicos nas escolas públicas, que por sua vez têm dificuldades de participar de uma formação presencial.

As Diretrizes Nacionais do PNGEB (2009) enfatizam as potencialidades da EaD, quando destaca que os cursos de formação para gestores escolares estruturados por meio dessa modalidade estão integrados a um conjunto de ações que são desenvolvidas presencialmente, sendo que todas pretendem "democratizar ainda mais o acesso a novos espaços e ações, com vistas ao fortalecimento da escola pública como direito social inalienável”. (p.8).

Dentre as potencialidades da $\mathrm{EaD}$ as Diretrizes sinalizam:

[...] maior flexibilidade na organização e desenvolvimento dos estudos; fortalecimento da autonomia intelectual no processo formativo; acesso às novas tecnologias da informação e comunicação; interiorização dos processos formativos, garantindo o acesso daqueles que atuam em escolas distantes dos grandes centros urbanos; redução dos custos de formação a médio e longo prazo; a interatividade entre os formandos, facilitando o trabalho coletivo; fortalecimento de infraestrutura adequada nas universidades públicas, estimulando a formação de grupos de produção científica na área de gestão escolar, e de formação de quadros para atuarem com EAD e sua institucionalização no tocante à formação continuada. (BRASIL, MEC/DN, 2009, p.8).

No mesmo sentido, percebemos que o PPC da UFT também enfatiza essas possibilidades da oferta do curso pela via da educação a distância. O documento ressalta que a UFT acredita nas potencialidades da EaD a partir das experiências em outros cursos ofertados. O documento expressa que "por meio das potencialidades da modalidade do ensino a distância, é possível proporcionar espaços de aprendizagens que ajudarão a romper com a "distância" social e principalmente cultural, que é uma dura realidade no estado do Tocantins". (PPC/UFT, 2010, p.4).

O documento também enfatiza que, por meio da $\mathrm{EaD}$, seria possível que professores e cursistas desenvolvessem processos de interação e que pudessem aprofundar o estudo das temáticas bem como construir conhecimentos e tivessem o "domínio de processos, procedimentos e ferramentas tecnológicas para ampliar e tornar mais efetiva a ação dos coordenadores pedagógicos no cotidiano escolar”. (PPC/UFT, 2010, p.12).

Sobre o desenvolvimento operacional do curso pela UFT, também percebemos mudança em relação ao PPC proposto pelo MEC no que se refere às equipes de trabalho. O MEC propôs que o curso tivesse um coordenador geral e um vice-coordenador, um coordenador para cada Sala Ambiente; Um professor, um assistente de turma para cada turma e um 
Assistente de polo, de modo que houvesse um representante da rede estadual ou municipal em cada polo.

Na proposta da UFT, o curso foi organizado, como observamos na Figura 5, pela coordenação geral e coordenação pedagógica. A geral foi formada por um coordenador geral e um vice-coordenador e o Grupo de Trabalho Interinstitucional, composto por representantes da UFT, UNDIME e Seduc-TO.

A coordenação pedagógica foi constituída pelos professores que aturam no curso num total de 35 professores, sendo cinco professores regentes, um para cada um dos cinco polos do curso. 10 professores de turma, 10 assistentes de turma e 10 assistentes de polo, sendo um para cada uma das 10 turmas.

Figura 5 - Equipes de trabalho do curso

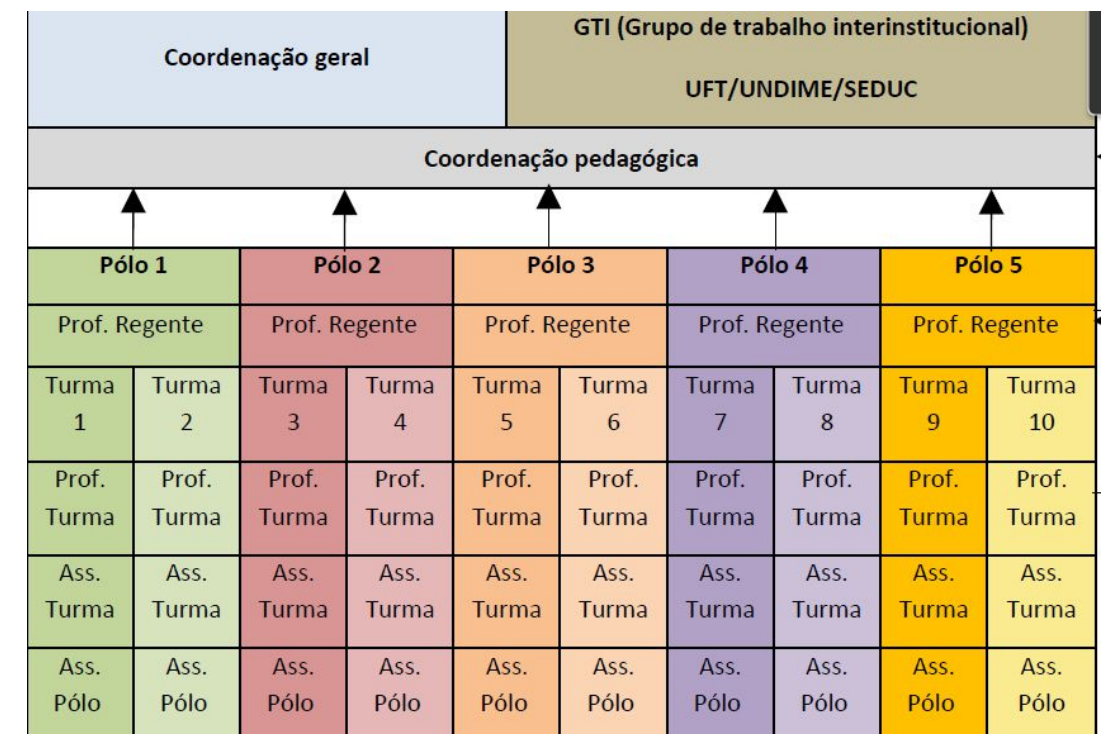

FONTE: PPC/UFT, 2010.

O professor regente era responsável por coordenar as ações pedagógicas e administrativas de duas turmas, atuando de forma síncrona nos encontros presenciais e assíncrona pelo ambiente de aprendizagem. Esse professor também tinha a função de orientar os alunos nas atividades e no TCC.

O professor de turma era responsável pelo desenvolvimento pedagógico das salas ambientes, bem como orientar e avaliar as atividades e o TCC. Esse professor deveria disponibilizar pelos menos $2 \mathrm{~h}$ por dia para as ações do curso. O Professor Assistente de turma tinha como função auxiliar o trabalho pedagógico e administrativo da turma atuando de forma assíncrona pelo AVA. Podia também, quando necessário e de acordo com sua formação, assumir conteúdo das salas ambientes, bem como orientar atividades e trabalhos de TCC. 
O professor assistente de polo também auxiliava o professor de turma nas atividades acadêmicas e administrativas, mas desenvolvia ações de modo a reter a evasão dos cursistas, além de prestar assistência presencial sobre dúvidas das atividades e, quando necessário, no desenvolvimento dos TCCs.

Cada turma do curso contou com a presença de pelo menos três professores os quais, embora com funções diferentes, se dedicavam integralmente ao desenvolvimento do curso em todas as suas fases, inclusive no desenvolvimento dos conteúdos das salas ambientes, bem como, na orientação dos fóruns e atividades, nas dúvidas sobre conteúdos, na orientação dos TCCs e, ainda, sobre problemas técnicos.

O Documento de Diretrizes do PNEGEB ressalta a importância do papel e função dos professores em cursos a distância, como evidenciado no trecho: "A manutenção do papel do professor em detrimento a adoção da figura do tutor é um dos marcos políticos do Programa", (p.8). A proposta da UFT considerou todos os agentes envolvidos na formação de professores como sendo também professores, não trabalhando com a figura do tutor.

Em relação ao financiamento do curso, que é realizado mediante a estratégia de descentralização de recursos efetivados pelo MEC FFNDE após a aprovação do PTA, temos que o curso em análise, teve o PTA da UFT aprovado com o valor de financiamento de R\$ 512.036,51 (quinhentos e doze mil e trinta e seis reais e cinquenta e um centavos), sendo planejado para executar as ações de pagamento de bolsas de extensão, pagamento de professores, diárias e passagens para os deslocamentos dos professores aos encontros presenciais, bem como para material de consumo. (UFT, PTA, 2009).

Essas são algumas características da operacionalização e desenvolvimento do curso de especialização lato sensu para Coordenadores Pedagógicos do PNEGEB ofertado pela UFT. De forma geral, apreendemos pelos documentos oficiais, que há a intenção de se desenvolver uma proposta de formação para profissionais que busca uma perspectiva de integração do percurso formativo teórico com as práticas do cotidiano desses profissionais.

Percebemos que embora o MEC aponte as diretrizes para o curso, a UFT como instituição formadora, apresentou-se em algumas etapas do curso, com autonomia para realizar mudanças, alterar o percurso do curso, propor ações inovadoras como a de um projeto de avaliação para o curso, dentre outras ações que se destacam ao longo do seu desenvolvimento.

No entanto, mesmo que diante de apontamentos positivos que sinalizam que o curso de coordenadores pedagógicos e o PNEGEB poderiam se tornar uma referência para a formação 
dos profissionais da gestão educacional, percebemos que se trata de uma política que não tem sido acompanhada e avaliada, embora os recursos investidos sejam bem expressivos.

Como apontou Fernandes (2015), o PNEGEB pensado para ser uma política permanente de formação de gestores escolares, "no que tange às perspectivas, paira a insegurança quanto à continuidade do Programa, por ser uma iniciativa de governo". (p.10). Essa perspectiva da autora é muito atual quando identificamos no mesmo governo, ou partido de governo, em que se criou o PNEGEB, que outras ações têm sido planejadas com os mesmos objetivos para a formação de gestores escolares, sem que as ações já iniciadas tenham acompanhamento.

Recentemente, em 2015, foi lançado pelo MEC o Programa Nacional de Formação e Certificação de Diretores Escolares (PNFCD), instituído pela Portaria 1.118 de 3 de dezembro de 2015, apresentando os objetivos de formar profissionais da área de gestão escolar por meio de cursos de formação continuada e extensão.

Em relação a esse Programa, a diretora global do Banco Mundial, Cláudia Costin, em ocasião de sua participação em evento no Brasil, em que fora anunciado o referido Programa, o considerou como muito importante, apontando que os professores não têm formação adequada para exercer os cargos de direção.

Ressaltou a diretora que: "As pesquisas mostram que o papel do diretor de escola é decisivo para criar um ambiente escolar propício à aprendizagem. [...] o programa de formação e certificação de diretores pode ser muito positivo. Isso vai levar a uma gestão mais profissionalizada" (ZINET, 2015).

Embora esse programa seja específico para a formação e certificação de diretores escolares, vemos que os programas não se comunicam não se interligam, apesar de apresentar objetivos em comum e pertencer às ações de um mesmo governo, considerando o mesmo partido político.

\subsection{O PNEGEB em ação - mapeamento das produções no Brasil}

A partir da compreensão sobre as origens e características do Programa Nacional Escola de Gestores da Educação Básica, bem como sobre as características do curso de especialização para Coordenadores Pedagógicos, desenvolvido no Tocantins, passamos nesse tópico à apreensão sobre as produções científicas em torno desse Programa em âmbito nacional. 
Visando construir uma espécie de "estado do conhecimento" sobre as pesquisas de mestrado e doutorado que tiveram como objeto de estudo o PNEGEB, realizamos um levantamento das produções científicas a partir de consulta ao Banco de Teses \& Dissertações online da Capes, disponível no endereço eletrônico http://bancodeteses.capes.gov.br/bancoteses/\#/.

Realizamos um mapeamento das produções no sentido da construção de uma espécie de "estado do Conhecimento", sem a pretensão de desenvolver um "Estado da Arte" sobre o assunto. Corroboramos com a classificação de Romanowski e Ens (2006) de que o estudo de produções que aborda um único setor de publicações sobre determinado tema.

Como o nosso foco é conhecer as produções de mestrado e doutorado sobre o PNGEB no Brasil a partir da busca de publicações em apenas um local, no caso o Banco de dados de Teses e Dissertações da Capes, é melhor denominado de "estado de conhecimento", diferenciando-se do "estado da arte", o qual caracteriza as pesquisas que abrangem a totalidade da produção de conhecimento de uma determinada área a partir do levantamento de vários tipos e aspectos de produções.

Embora recentes, os estudos de "estado da arte" que objetivam a sistematização da produção numa determinada área do conhecimento já se tornaram imprescindíveis para apreender a amplitude do que vem sendo produzido. Os estudos realizados a partir de uma sistematização de dados, denominada "estado da arte", recebem esta denominação quando abrangem toda uma área do conhecimento, nos diferentes aspectos que geraram produções. Por exemplo: para realizar um "estado da arte" sobre "Formação de Professores no Brasil" não basta apenas estudar os resumos de dissertações e teses, são necessários estudos sobre as produções em congressos na área, estudos sobre as publicações em periódicos da área. O estudo que aborda apenas um setor das publicações sobre o tema estudado vem sendo denominado de "estado do conhecimento". (ROMANOWSKI, ENS, 2006. p.39-40). (grifos nossos).

Nesse sentido, é que realizamos o mapeamento, no qual a etapa de consulta e levantamento dos dados foi realizada por meio da inserção de três descritores no campo de pesquisa on-line do Banco de dados da Capes denominado de "Busca Básica", a fim de obtermos o maior número de registros das produções sobre o PNEGEB. Sobre o primeiro descritor "Programa Nacional Escola de Gestores" obtivemos o registro de 26 trabalhos entre teses e dissertações. Sobre o segundo descritor "Programa Escola de Gestores", retirando o termo "Nacional", o Banco registrou 11 produções e sobre o terceiro descritor "Escola de Gestores", obtivemos o maior número de pesquisas, com 33 registros. 
A partir desse último descritor "Escola de Gestores" com o maior número de registros das produções, passamos à seleção das produções. Na sequência, passamos às primeiras análises dessas produções, realizando a leitura dos resumos e dos textos de introdução dos 33 trabalhos, dos quais, sete eram teses e 26 dissertações, sendo uma dessas de mestrado profissional. Dessas produções referentes às dissertações, a maioria delas (24) era de programas de pesquisas da área de educação e duas de outras áreas, uma de Letras e outra da Administração. Com relação às produções de doutorado, das sete teses registradas, cinco delas eram da área de educação e duas da área de Difusão do Conhecimento.

Considerando essas produções dos programas de pós-graduação stricto sensu a partir das regiões geográficas no Brasil em que foram realizados, evidenciamos que os programas da região sudeste e nordeste apresentaram o maior número de estudos sobre o Programa Escola de Gestores, tanto em relação às pesquisas de mestrado quanto de doutorado, conforme observamos pelo Gráfico 1.

Com relação ao menor quantitativo de produções por regiões, percebemos que os referentes aos trabalhos de mestrado se concentram nos programas das regiões Sul e Norte e os de doutorado, no norte do país. Também observamos que nas regiões Sul e Centro-Oeste não houve nenhuma produção de tese.

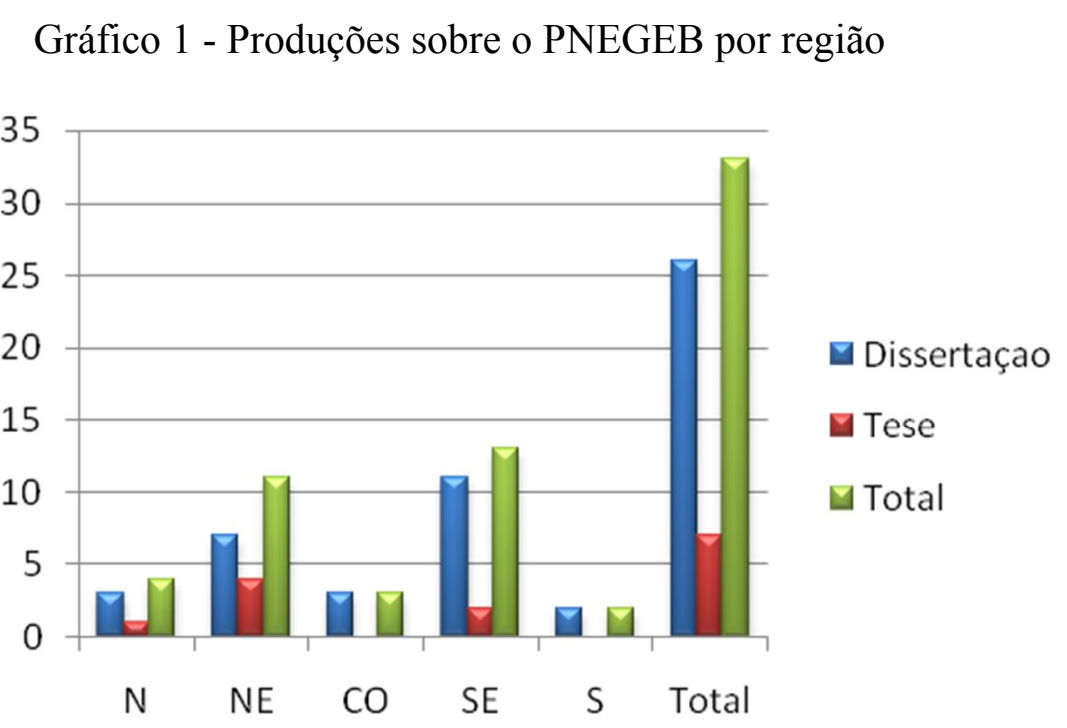

FONTE: Dados do Banco de Teses e Dissertações. Capes, 2016.

Considerando o recorte temporal para o levantamento das produções entre os anos de 2009 a 2016, o que se justifica por ter sido o período que marca a implementação legal do Programa no Brasil por meio da Portaria Ministerial nº 145 em 2009, até as produções mais 
atuais do ano de 2016, constatamos que o maior quantitativo de produções se destaca entre os anos de 2010 e 2012 como observamos pela Tabela 1 e são representados na sua maioria pelas pesquisas de mestrado em educação, enquanto o maior número de teses se destaca no ano de 2015.

Tabela 1 - Produções sobre o PNEGEB por ano.

\begin{tabular}{ccccc}
\hline \multirow{2}{*}{ Prod./ Ano } & \multicolumn{2}{c}{ DISSERTAÇÕES } & \multicolumn{2}{c}{ TESES } \\
\cline { 2 - 5 } & Educação & Outros & Educação & Outros \\
\hline 2009 & 3 & 1 & 1 & 0 \\
2010 & 4 & 1 & 0 & 0 \\
2011 & 3 & 0 & 0 & 0 \\
2012 & 6 & 0 & 0 & 0 \\
2013 & 2 & 0 & 0 & 1 \\
2014 & 2 & 2 & 1 & 1 \\
2015 & 2 & 0 & 3 & 0 \\
TOTAL & $\mathbf{2 2}$ & $\mathbf{4}$ & $\mathbf{5}$ & $\mathbf{2}$ \\
\hline
\end{tabular}

FONTE: Dados do Banco de Teses e Dissertações. Capes, 2016.

Importante ressaltar que, nessa fase da análise das produções, em que fizemos a leitura dos resumos das pesquisas, foi necessário realizar outras buscas nos próprios sites dos programas de pós-graduação stricto sensu e também em sites de pesquisas como o "Google" e "Google Acadêmico" para termos o acesso a pelo menos 20 dissertações que não possuíam os detalhes de suas produções, conforme os registros disponibilizados no Banco da Capes pela Plataforma Sucupira. Como essa plataforma foi implantada em 2014, as publicações anteriores ao ano de 2013 não são fornecidas pelo Banco de Dados, sendo divulgadas apenas informações sobre o autor, título, ano e instituição em que a pesquisa foi realizada.

No entanto, mesmo por meio dessas buscas livres, também não conseguimos o acesso a todos os trabalhos, restando ainda seis que não foram encontrados. Assim, o universo das publicações diminuiu para 27, sendo 20 dissertações e sete teses. Nessa fase analítica, a partir da primeira leitura a partir dos resumos, evidenciamos que as pesquisas apresentavam proximidades com diferentes áreas do conhecimento, como em Administração em geral, em Currículo, em Informática, em Políticas da Educação, em Práticas de Ensino e em Psicologia, como visualizamos pelo Gráfico 2. 
Gráfico 2 - Áreas do conhecimento das produções sobre o PNEGEB

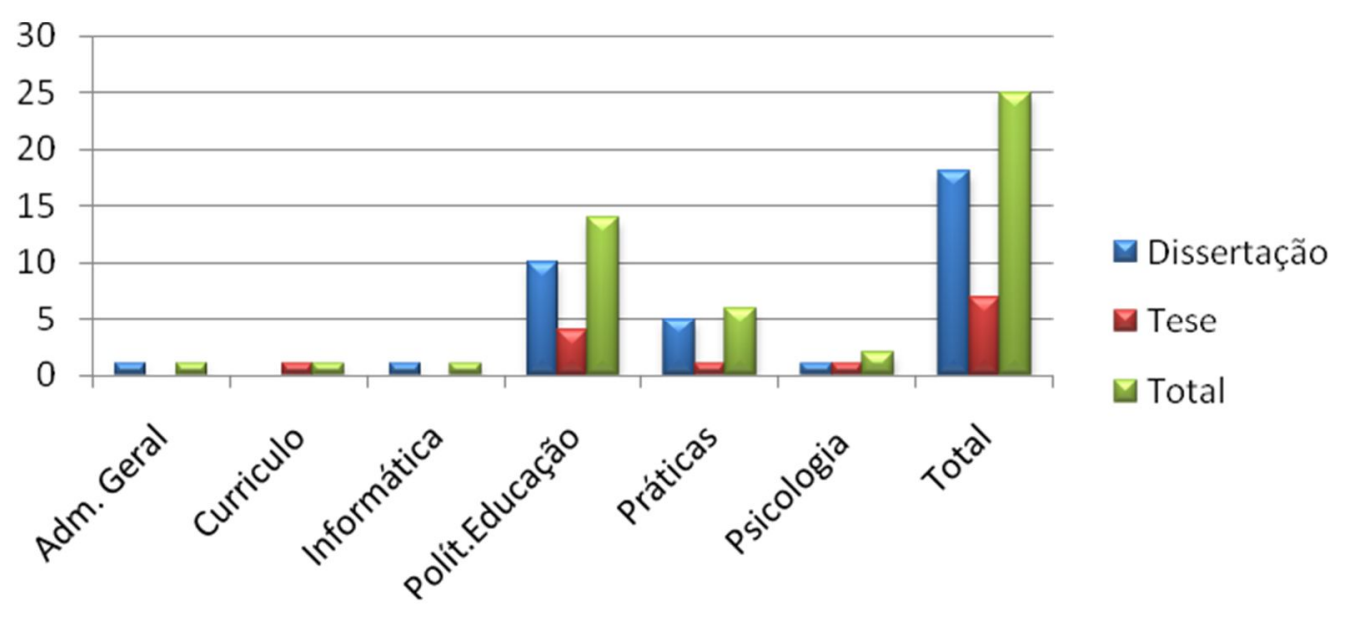

FONTE: Dados do Banco de Teses e Dissertações. Capes, 2016.

Esse Gráfico aponta que a maior produção de pesquisas sobre o Programa Escola de Gestores foi desenvolvida na área de políticas da educação, como vemos representado por 14 trabalhos, dentre eles, 10 dissertações e quatro teses. Diante desses resultados e considerando o nosso foco de estudo, que é da área de políticas e gestão da educação, passamos a considerar na fase de aprofundamento das análises, esse número de produções, ou seja, o total de 14 produções acadêmicas.

Nessa etapa de aprofundamento das análises, focalizamos as leituras a partir dos resumos e introdução dos trabalhos completos, visando compreender os objetivos e os principais resultados apresentados. Buscamos, ainda, evidenciar os principais enfoques dos estudos sobre o PNEGEB, no sentido de ter uma visão de totalidade e obter elementos para a compreensão do concreto pensado, síntese da formação dos coordenadores pedagógicos, foco da nossa pesquisa de doutorado.

As análises das 14 produções selecionadas (teses e dissertações) apontaram que há uma tendência predominante sobre os estudos que se reportaram ao curso de especialização lato sensu em Gestão Escolar, sendo que apenas duas pesquisas focalizaram o curso de especialização lato sensu em Coordenação Pedagógica e que, por sua vez, embora fossem as únicas encontradas sobre o nosso recorte dessa pesquisa, elas não foram consideradas para as análises, conforme destacamos no texto de introdução dessa tese.

De modo geral, quanto aos objetivos, temos que as produções de mestrado e doutorado, entre as 14 selecionadas, buscaram analisar a implantação dos cursos de gestão escolar e seus impactos para a formação e prática dos gestores. Em relação aos principais 
resultados, as pesquisas apontaram que a formação continuada ofertada nos cursos de pósgraduação por meio do PNEGEB foi considerada positiva.

De forma mais específica, considerando os 10 trabalhos de mestrado da área de política da educação, apreendemos que, a dissertação realizada no ano de 2009, intitulada "Concepções sobre Gestão Escolar entre os egressos do curso de especialização em Gestão Escolar do polo de JOACAB”, de Marco André Serighelli, buscou investigar as concepções que os gestores egressos desse curso tinham sobre a gestão escolar.

A pesquisa tomou como amostra para o estudo os egressos do curso sob a responsabilidade de Polo de educação a distância de Joaçaba, responsável pela oferta em vários municípios da região. A título de contextualização, a pesquisa aborda, inicialmente, a centralidade adquirida pela gestão escolar no interior da reforma educacional dos anos de 1990.

A linha teórica baseia-se na concepção de gestão democrática das escolas, valoriza os processos participativos na gestão escolar, com o envolvimento de todos os seus atores, buscando destacar entre os egressos do curso a sua compreensão a respeito da gestão escolar utilizando como categorias para análise além da concepção de gestão escolar, as concepções sobre autonomia da escola pública e de participação política nos processos de gestão escolar.

Dentre seus resultados, essa dissertação de 2009 mostra que os egressos manifestaram um entendimento de gestão escolar democrática voltada ao direito de todos à educação, ressaltando o reconhecimento de que essa compreensão exige a implementação de diversos mecanismos de participação da comunidade escolar e local para os encaminhamentos administrativos e pedagógicos relativos aos trabalhos escolares.

No ano de 2010, identificamos uma pesquisa de mestrado realizada na Paraíba, com o título "O Programa Escola de Gestores na UFPB: olhares e propostas dos gestores egressos", de Alba Lúcia Nunes Gomes, que analisou a implementação do curso de especialização em Gestão Escolar, visando identificar: as suas contribuições para as práticas dos egressos, as dificuldades enfrentadas, bem como evidenciar as sugestões apresentadas pelos egressos para a melhoria do desenvolvimento do curso.

Segundo dados da pesquisa, ela situou o Programa Escola de Gestores no contexto da reforma do Estado, discutindo as políticas de educação superior e a formação continuada na modalidade a distância. Como base metodológica, foi utilizada uma abordagem qualitativa da pesquisa e, como instrumentos de coleta de dados, utilizaram-se a análise de documentos e a realização de entrevistas. 
De forma geral, a pesquisa aponta que a maioria dos cursistas pouco sabia sobre o curso, no entanto eles reconheceram e destacaram a contribuição dele para sua formação na área de gestão e para o melhoramento das práticas gestoras na escola.

Outros resultados são destacados no resumo do trabalho de Gomes (2010).

[...] a maior contribuição do programa para os gestores foi a aprendizagem da sistematização das ações da escola e o conhecimento teórico. Em relação a modalidade EAD adotada, afirmam que o curso possibilitou formar o hábito de estudo, devido a característica precípua da EAD que é a flexibilização do tempo, entretanto, apontaram como dificuldade os insuficientes encontros presenciais por disciplina, o curto prazo para o envio das atividades, a dificuldade com a usabilidade do computador e com a Internet.

Em 2011, duas pesquisas de mestrado foram defendidas, sendo uma na Universidade Federal de São Carlos e outra na Universidade Federal do Paraná. A primeira, com o título “Gestão educacional pós-municipalização: práticas patrimonialistas, poder e outros desafios na ótica dos gestores", da autora Beatriz Alves de Oliveira, analisou as formas de ocorrência das relações de poder a partir das representações sociais dos gestores de sete municípios do litoral de São Paulo, a respeito das mudanças ocorridas nas relações de poder no interior da escola, bem como nas relações com órgãos superiores.

A autora utilizou como categorias de análises os conceitos de dominação patrimonialista, dominação legal racional burocrática, autonomia, cooptação e gestão democrática. A partir de entrevistas aos diretores e vice-diretores participantes do curso de Gestão Escolar do PNEGEB no polo de Ilha Comprida a pesquisa ressalta dentre seus resultados que, embora a gestão educacional tenha modificado seu discurso na busca por democratização, o poder continua presente nas práticas e na hierarquia das instituições e nas relações delas com as instituições superiores. "Permanecem as práticas patrimonialistas e clientelistas nas práticas dos gestores, sejam elas impostas ou decididamente 'democraticamente'". (OLIVEIRA, 2011).

A dissertação do Paraná, de Marilza Aparecida Pereira Teixeira, denominada de "Formação para diretor escolar da educação básica: o Programa Nacional Escola de Gestores no Estado do Paraná" (2011), discutiu sobre a efetividade do PNEGEB e o possível alcance dessa política no Estado do Paraná. A pesquisa analisa a proposta do Programa e identifica que ele visa modificar a atuação dos diretores da escola básica, por meio de conhecimentos sobre a gestão democrática e o direito à educação, bem como busca constituir uma rede nacional de troca de experiências para os diretores, a partir da experiência paranaense. 
Realizou-se a aplicação de um questionário aplicado aos cursistas concluintes do programa e análise dos trabalhos de conclusão de curso (TCC), constatando que houve alcance parcial dos objetivos da proposta, pois houve muita evasão e um baixo rendimento na aprendizagem dos sujeitos. Como causa desses problemas, a pesquisa destaca as relações como "o período da realização, a dificuldade dos cursistas em manter disciplina para a realização do curso em EAD, bem como situações de organização do curso pela própria UFPR”. (TEIXEIRA, 2011).

No ano de 2012, identificamos no Banco de Dados da Capes uma pesquisa de mestrado com o título "A Prática discursiva das contribuições da Escola de Gestores para a gestão escolar democrática”, de Lindalva Gouveia Nascimento, que analisou as contribuições do curso de especialização, também em Gestão Escolar, para as práticas dos gestores das escolas públicas municipais de Areia na Paraíba.

A temática foi problematizada a partir da análise de implantação de uma política pública a partir desse curso voltado para gestores de escolas com baixo IDEB, constituindo-se como um estudo de caso. Utilizando-se a análise dos documentos oficiais do PNEGEB, constatou-se que esses documentos apresentam uma concepção de formação voltada para a oferta de elementos teóricos e práticos que viabilizam uma educação escolar com qualidade social.

Também foi utilizada a aplicação de questionários e entrevistas e, de forma geral, os dados da pesquisa apontam que a formação continuada contribuiu para mudanças de práticas gestoriais a partir de uma perspectiva de gestão democrática.

A produção de mestrado que marca o ano de 2013 tem como título "Os tempos e espaços do gestor escolar em formação na educação a distância”, da pesquisadora Aline Gabriele Pereira, foi realizada na Universidade Federal de Minas Gerais. Teve como objeto compreender os tempos e espaços utilizados pelos gestores na realização da formação continuada por meio do curso em Gestão Escolar.

Os resultados consideram o fato de o curso ser ofertado na modalidade a distância e ter o fator tecnológico como responsável por exercer grande influência sobre os tempos e espaços dos sujeitos investigados, como em relação às dificuldades de acesso e usabilidade dos recursos, a questão relacionada à disponibilização do tempo de estudo com o tempo de trabalho e tempo com a família e o fator emocional que envolve a maioria do público do sexo feminino do curso. 
Duas dissertações são registradas no ano de 2014. Uma com o título "Políticas Educacionais de Formação Continuada: estudo a partir dos projetos de intervenção desenvolvidos no curso de Especialização em Gestão Escolar/UFOPA”, da pesquisadora Glauciene Sebastiana Nogueira Lima, realizada na Universidade Federal do Oeste do Pará (UFOPA).

Essa pesquisa analisou os Projetos de Intervenção (PI) do curso de formação continuada em Gestão Escolar do PNEGEB, ofertado pela Universidade Federal do Oeste do Pará (UFOPA), de forma a evidenciar a contribuição desses projetos para a reflexão em torno da gestão democrática.

A pesquisa de natureza bibliográfica e documental teve como fonte os artigos produzidos para a conclusão do curso em 2011, além dos documentos reguladores do programa e projeto pedagógico do curso, pautando-se em referências que enfocam a trajetória de concepções sobre gestão escolar, gestão educacional e gestão democrática, salientando ressignificações e concepções de processos democráticos.

Dentre seus resultados, o resumo da pesquisa aponta:

[...] os discursos expressos nos PI, evidenciam que se tem uma concepção de PPP (foco dos PI no curso) como um guia e recurso para os problemas da escola, mas se percebe a contradição desse documento para efetivação da gestão democrática quando expressam ou são expressos os limites, os desafios e as questões legais como imposição à escola e a falta de compromisso de certos profissionais com a atividade que desenvolvem, eximindo-se de participar de maneira efetiva. O PPP por si só não é sinônimo de gestão democrática. (LIMA, 2014).

Já a outra dissertação de 2014, intitulada “Construindo uma gestão democrática no Estado da Bahia: contribuições do Curso de Especialização em Gestão Escolar”, de Bruno Luiz Teles de Almeida, analisou a apropriação do conceito de gestão democrática participativa promovida no âmbito do curso de Especialização em Gestão Escolar do Programa Escola de Gestores da Universidade Federal da Bahia UFBA e suas contribuições para o fortalecimento da gestão democrática nas escolas públicas da educação básica da Bahia, por meio de análises dos trabalhos de conclusão do curso.

Os resultados apontaram que uma grande porcentagem dos trabalhos demonstrou a apropriação total ou parcial do conceito de Gestão Democrática Participativa e também ressaltou ter contado com a participação da comunidade escolar no processo de elaboração 
e/ou implementação do projeto de intervenção que deu origem ao Trabalho de Conclusão de Curso.

Os últimos dois registros de produções de mestrado são do ano de 2015. Uma dissertação com o título "Políticas Públicas de Formação do gestor escolar na rede municipal de Salvador - BA: uma análise do curso de gestão escolar”, do pesquisador Leandro Gileno Militão Nascimento, e teve como objetivo analisar o curso de gestão escolar de forma a contribuir com proposições, bem como reconhecer os pontos favoráveis.

Foi desenvolvido um estudo sobre as políticas públicas de formação de gestores escolares no Brasil, com maior dedicação a dois programas de formação de gestores, PROGESTÃO e o Programa Nacional de Escola de Gestores da Educação Básica Pública, a partir do levantamento da legislação sobre gestão escolar e formação do gestor.

Dentre os resultados, a pesquisa destaca em seu resumo que:

[...] os cursos de gestão escolar tiveram algumas fragilidades, entre as quais o fato de serem muito teóricos e de pouco auxiliarem aos gestores escolares no desenvolvimento das competências de resultado, planejamento, lideranças pedagógicas e administrativas. Como ponto favorável destacamos que os cursos proporcionaram momentos de estudo, despertando o interesse pelo tema da gestão escolar e a importância de continuar estudando e se aprofundando nas temáticas da gestão escolar. Recomenda-se à Secretaria Municipal Educação de Salvador - BA privilegiar, em suas políticas educacionais, a formação continuada específica dos gestores escolares, a partir de parcerias com as Universidades de Salvador-BA, as quais, por excelência, são agências formadoras que podem conduzir a formação dos profissionais de educação, além de aproximar o gestor ao meio acadêmico, despertando o interesse pela pesquisa. (NASCIMENTO, 2005).

A outra dissertação de 2015, intitulada "A prática pedagógica dos gestores escolares: a implementação da Escola de Gestores UFMG no polo Montes Claros, MG”, de Giselle Cristina Rodrigues, analisou as implicações da formação continuada em serviço na modalidade da educação a distância, na rotina administrativa e na prática pedagógica dos gestores escolares do curso de Gestão Escolar, buscando identificar e analisar as possíveis dificuldades na implementação desse curso no polo de Montes Claros - MG.

$\mathrm{O}$ estudo tomou, como seu objeto de estudo, os Gestores Escolares e os dirigentes Municipais de Educação envolvidos no curso do polo de Montes Claros, sendo realizada entrevista com três dirigentes municipais de educação e quatro gestoras educacionais. Abordou-se sobre a formação continuada dos gestores escolares numa perspectiva de gestão democrática, tendo em vista perceber os fatores que facilitam e ou dificultam essa formação 
na modalidade $\mathrm{EaD}$ e os espaços e tempos dos gestores escolares em seus processos de formação continuada.

Os resultados dessa pesquisa apontam que o curso contribuiu para o avanço sobre a concepção e a prática da gestão escolar, no entanto também destacam que ele apresentou problemas em sua implantação e na sua efetivação nos municípios do polo de Montes Claros.

Em relação aos trabalhos de doutorado, todos os quatro registrados no Banco de Dados da Capes e analisados, apresentaram como objetivos de suas pesquisas a avaliação da política de formação de professores/gestores a partir de experiências nos cursos de Gestão Escolar. Uma tese foi desenvolvida no ano de 2014 e as outras três teses foram desenvolvidas no ano de 2015 .

A pesquisa de 2014 com o título "Formação do Gestor Escolar em Curso de pósgraduação: análise da experiência da escola de gestores da educação básica em Pernambuco", de Darci Barbosa Lira Melo, teve como objetivo analisar o processo de construção do curso de pós-graduação lato sensu e como os egressos o avaliou, tendo como foco o I Curso de Especialização em Gestão Escolar, ofertado pela Universidade Federal de Pernambuco (UFPE).

Apresentou como suporte teórico o debate sobre a gestão democrática da educação e da escola, o que permitiu examinar, à luz do contexto sócio-histórico, as várias dimensões do curso, o modelo de formação continuada na área de gestão da educação na modalidade EaD. Foi realizada a análise de documentos da Secretaria de Educação Básica do MEC, e dos Relatórios de Avaliação do Curso, e também foram aplicados questionários aos professores, representantes da UNDIME e da Secretária de Educação do Estado de Pernambuco (SEE/PE), que atuaram como parceiros no regime de colaboração e aos egressos do curso.

As análises apontaram a ocorrência de uma diferença significativa entre a compreensão das diretrizes do Programa que foram reinterpretadas no contexto da prática, em que se articulou a produção de orientações oficiais e as experiências locais. Dentre os principais resultados, evidenciaram-se uma avaliação positiva do curso e um entendimento de gestão escolar democrática voltada ao direito de todos à educação.

Também foi destacada a necessidade de implementação de mecanismos de participação e a autonomia da comunidade escolar e local para os encaminhamentos administrativos e pedagógicos relativos aos trabalhos escolares. Essa dinâmica foi interpretada como uma contribuição para a melhoria do desempenho profissional do gestor 
escolar, o que poderá contribuir para a melhoria dos índices educacionais do Estado de Pernambuco.

As outras três teses desenvolvidas no ano de 2015, uma foi realizada no programa de doutorado da Universidade Federal de Juiz de Fora (UFJF) e as outras duas no programa de doutorado da Universidade Federal do Rio Grande do Norte (UFRN).

A tese da UFJF teve como título "O Programa Escola de Gestores da Educação Básica e seus efeitos para a formação de gestores escolares em Minas Gerais", da pesquisadora Cássia do Campo Pires Fernandes, avaliou os resultados e efeitos do curso de especialização em Gestão Escolar do PNEGEB considerando as dimensões de quem elaborou a política (Ministério da Educação), de quem implementou (UFV) e dos beneficiários (egressos), tomando como ponto de partida a premissa de que a formação de gestores provoca mudanças na gestão escolar, contribuindo para a melhoria da qualidade da educação pública.

A pesquisadora utilizou entrevistas semiestruturadas com um Gestor do MEC, uma Gestora do Grupo de Trabalho Interinstitucional do Programa, uma Gestora da UFV e cinco diretoras de escolas e também aplicou questionários survey com 102 egressos.

Com relação à abordagem teórica, a pesquisa pautou-se na caracterização do PNEGEB, na abordagem dos temas da gestão escolar democrática, da formação de gestores escolares, bem como a análise e avaliação de políticas educacionais, sendo apresentada a Abordagem do Ciclo de Políticas como o modelo escolhido para analisar o curso.

Como resultados da pesquisa, a autora aponta que "foi possível confirmar a hipótese de que os resultados e efeitos positivos do curso são expressos num processo formativo de qualidade e que pode incidir sobre o desenvolvimento de uma gestão escolar democrática, segundo seus egressos"; no entanto, ela chama atenção sobre as perspectivas futuras para o curso, uma vez que "paira a insegurança quanto à continuidade do Programa". (FERNANDES, 2015).

As duas pesquisas de doutorado realizadas na UFRN são da linha de "Educação, Políticas e Práxis Educativas" do programa de educação dessa universidade. Uma foi defendida no mês de fevereiro e a outra no mês de junho de 2015. A primeira tem como título "Formação Continuada a distância para gestores escolares: estudo avaliativo da política de cursos de pós-graduação lato sensu (2009-2011)", da pesquisadora Dalva Gercina, e a segunda apresenta "Formação lato sensu a distância em Gestão Escolar", da pesquisadora Maria Aldeiza da Silva. 
Ambas estudaram o curso de especialização lato sensu em Gestão Escolar, mas a primeira focalizou a experiência ofertada no ano de 2009 a 2011 considerando o contexto de formulação e de implementação das políticas de educação brasileira, as particularidades da educação a distância e da implementação da especialização para gestores escolares, e a segunda focalizou a experiência do curso ofertado em 2010 a 2012.

Em relação à pesquisa de Gercina Dalva, tem-se dentre seus objetivos a análise do curso tendo em vista a busca de novos conhecimentos sobre o trabalho do gestor escolar. Foi utilizada a perspectiva metodológica do materialismo histórico dialético e como técnicas o questionário aplicado aos sujeitos da pesquisa, os gestores/cursistas, bem como a análise de dados obtidos a partir do ambiente virtual de aprendizagem moodle.

Os resultados apontaram para "contradições, limites e desafios na expansão do ensino superior com EAD” (DALVA, 20015), conforme aponta a autora, destacando que embora sejam evidenciadas mudanças históricas nas políticas educacionais, elas não incidiram em rupturas nos padrões tradicionais de formação de gestores. A autora também destaca:

Todavia, mesmo em face às mudanças na sociedade global e informacional, não ocorreram rupturas nos padrões tradicionais de formação dos profissionais da educação, em particular os gestores escolares. Embora o curso tenha suscitado novos conhecimentos inerentes à gestão escolar, apresenta lacunas que só podem ser preenchidas pela modalidade de ensino presencial. Os cursistas, em descompasso com os reclamos da sociedade em mudança, e, em particular com o mundo do trabalho, ainda não incorporaram suficientemente os conhecimentos relativos às novas tecnologias para enfrentar os desafios do dia a dia. Consideraram limitadas as condições de estudo, por não se adequarem ao tempo de trabalho, e, do ponto de vista técnico, é precário o acesso ao computador e à internet. (DALVA, 2015).

A segunda tese focalizou a experiência do curso de especialização em Gestão Escolar ofertado em 2010 a 2012 analisando a política de formação a distância de gestores de escolas públicas, visando à possibilidade de contribuir por meio de uma perspectiva teórica e metodológica sobre a gestão democrática nos processos de organização escolar. Sobre os resultados dessa pesquisa reproduzimos o trecho do resumo na íntegra:

Os resultados apontam para posições que divergem/convergem para o foco da formação, quais sejam: 1) os cursistas apontaram fragilidades no trabalho nas escolas com vistas a mobilizar o coletivo escolar para a realização de práticas de gestão democrática; 2) indicam haver contradições entre a metodologia inovadora proposta para a formação, o conteúdo organizado para o curso e as estratégias didáticas e metodológicas aplicadas nas atividades, já que os encaminhamentos conduzem às práticas gerencialistas que vão de encontro ao princípio norteador da formação; 3) nas concepções de gestão que permeiam o trabalho do gestor escolar, os cursistas fazem 
referências à ênfase em práticas burocráticas e ao embate entre as concepções gerencial e democrática; 4) os trabalhos científicos finais dos cursistas apresentavam, em sua maioria, propostas de intervenção e nas ações realizadas nos eixos Projeto Político-Pedagógico, Gestão Democrática Participativa e Conselho Escolar; 5) No que se refere à modalidade EAD, chamam a atenção os índices de evasão, motivados por dificuldades específicas dos cursistas, por algumas práticas formadoras ao longo do curso, bem como pelas condições dadas no correr do processo formativo. Portanto, o programa Escola de Gestores se constitui numa política pública de formação docente importante, que apresenta fundamentos sobre a gestão democrática da escola e contribui positivamente para a revisão de práticas/concepções, embora seja possível evidenciar ainda contradições no processo que acabam, por sua vez, a conduzir para práticas de gestão gerencialista. (SILVA, 2015).

Em relação a essas duas teses, os resumos não deixaram claro se a análise do curso de especialização em Gestão Escolar se tratou de experiências diferentes, mas por meio de inferências considerando os períodos das ofertas dos cursos, acreditamos que se trata de cursos diferentes, portanto, atores e resultados diferentes.

Embora as produções mapeadas demarquem resultados positivos com relação aos cursos de especialização analisados no contexto do PNEGEB, há alguns trabalhos que apontam contradições, como anunciado na Introdução.

Em relação às dissertações, as pesquisas de Oliveira (2011) e Lima (2014) destacam entre seus resultados:

a. Permanecem as práticas patrimonialistas e clientelistas nas práticas dos gestores, sejam elas impostas ou decididamente 'democráticas'. (OLIVEIRA, 2011). (Grifos nossos)

b.os discursos expressos nos PI, evidenciam que se tem uma concepção de PPP [...] como um guia e recurso para os problemas da escola, mas se percebe a contradição desse documento para efetivação da gestão democrática quando expressam ou são expressos os limites, os desafios e as questões legais como imposição à escola e a falta de compromisso de certos profissionais com a atividade que desenvolvem, eximindo-se de participar de maneira efetiva. O PPP por si só não é sinônimo de gestão democrática. (LIMA, 2014). (grifos nossos).

No caso das pesquisas de doutorado, destacam-se as teses de Silva (2015) e de Gercina (2015) que também pontuaram algumas contradições. A primeira destaca:

1) os cursistas apontaram fragilidades no trabalho nas escolas com vistas a mobilizar o coletivo escolar para a realização de práticas de gestão democrática; 2) indicam haver contradições entre a metodologia inovadora proposta para a formação [...] já que os encaminhamentos conduzem às 
práticas gerencialistas que vão de encontro ao princípio norteador da formação; 3) nas concepções de gestão que permeiam o trabalho do gestor escolar, os cursistas fazem referências à êfase em práticas burocráticas e ao embate entre as concepções gerencial e democrática; [...] 5) No que se refere à modalidade EAD, chamam a atenção os índices de evasão, motivados por dificuldades específicas dos cursistas, por algumas práticas formadoras ao longo do curso, bem como pelas condições dadas no correr do processo formativo. Portanto, o programa Escola de Gestores se constitui numa política pública de formação docente importante, [...] embora seja possível evidenciar ainda contradições no processo que acabam, por sua vez, a conduzir para práticas de gestão gerencialista. (SILVA, 2015). (grifos nossos).

A segunda tese intitulada de "Formação Continuada a Distância para gestores escolares: estudo avaliativo da política de cursos de pós-graduação lato sensu (2009-2011)", de Gercina (2015), também destaca que, embora sejam evidenciadas mudanças históricas nas políticas educacionais, elas não incidiram em rupturas nos padrões tradicionais de formação de gestores. A autora destaca, ainda, que embora o curso tenha suscitado a produção de novos conhecimentos inerentes à gestão escolar, ele apresenta lacunas que só podem ser preenchidas pela modalidade de ensino presencial.

Essas contradições representam um quantitativo pequeno, mas bastante significativo. O sentido que essas mensagens expressam indica que entre o discurso oficial da política e a realidade vivida pelos gestores escolares, há um movimento contraditório que se explicita nas práticas burocráticas e clientelistas da gestão.

Além dessas questões, o mapeamento também tornou explícito o entendimento que se tem na universidade brasileira sobre o PNEGEB que, de forma geral, expressa uma leitura positiva sobre o Programa, mas que, pelo menos quatro produções entre as 14 mapeadas, mostram que há contradições.

\subsection{Síntese do Capítulo}

O PNEGEB como uma das ações da política de formação de professores/gestores nasce num período político e social em que as demandas por formação desses profissionais são enormes, tanto do ponto de vista dos profissionais que anseiam por formação, quanto do ponto de vista da estrutura normativa do Estado em busca de ações que fortaleçam a educação e alcance os índices necessários de qualidade educacional.

Vemos que, desde sua origem, o Programa busca se constituir como um espaço de formação que tem como alvo a gestão democrática e que, em termos metodológicos, optou 
pela educação a distância como modalidade possível para a formação dos gestores em efetivo exercício. Nesse contexto, a experiência do curso de coordenação pedagógica desenvolvida no estado do Tocantins no período de 2010-2011, como expressa seus relatórios, apresentou-se como uma experiência positiva.

Por sua vez, essa parece ser a perspectiva das experiências do PNEGEB no Brasil, embora existam algumas contradições, conforme evidenciamos no mapeamento realizado sobre as pesquisas de mestrados e doutorado a partir dos dados do Banco de Dados da Capes.

Como apreendido a partir desse mapeamento, apenas duas pesquisas foram realizadas sobre o curso de Coordenação Pedagógica no âmbito e que não fizeram parte das análises, pois não era da área de educação ou da linha de políticas e educação.

Evidenciamos a predominância dos estudos relacionados ao curso de especialização para Gestão Escolar, dos quais a maioria foi realizada nos programas de pesquisas da região Nordeste e Sudeste do país, o que nos leva a questionar a ausência de produções nas regiões Sul e Sudeste, as quais possuem muitos programas de pesquisas na área de educação.

Outro fator que também chama atenção é o pequeno quantitativo de 33 produções encontradas sobre o PNEGEB no Brasil, Programa que se institucionaliza dentre as ações da política de formação para gestores escolares, considerando o universo de "13516" registros sobre o descritor relacionado à "formação de professores".

Como situamos, as pesquisas sobre formação de professores a partir da educação a distância tem sido eixo crescente de interesse em muitos programas de pós-graduação stricto sensu no Brasil, no entanto pesquisas que se referem à temática da formação de professores/gestores por meio da $\mathrm{EaD}$ e, em especial, aquelas que tomam o Programa Nacional Escola de Gestores como objeto de estudo, ainda é um número de produções bem tímido. 


\title{
CAPÍTULO V - VISÕES DOS PARTICIPANTES DO CURSO DE ESPECIALIZAÇÃO EM COORDENAÇÃO PEDAGÓGICA
}

\author{
Os homens são os produtores das suas \\ representações, ideias, etc., mas os homens reais, \\ os homens que realizam, tal como se encontram \\ condicionados por um determinado \\ desenvolvimento das suas forças produtivas e \\ pelas relações que a estas correspondem até as \\ suas formações mais avançadas. \\ Marx, Engels, 2009.
}

\subsection{Apontamentos Iniciais do Capítulo}

Neste capítulo, discutimos questões mais específicas sobre a experiência da formação dos coordenadores pedagógicos, a partir das análises dos questionários respondidos pelos participantes do curso, com a intenção de desenvolver melhor aproximação com o objeto de investigação.

Nesse movimento, o diálogo com as categorias dialéticas da Contradição, do Trabalho e da Prática Social são tomadas como categorias de análise tendo em vista suas relações de totalidade. Adicionalmente, as categorias gramscianas da hegemonia e contra-hegemonia foram utilizadas para detalhamento dessas percepções.

Se o Trabalho, como categoria marxiana na sua perspectiva ontológica, representa uma possibilidade de transformação intencional da natureza a partir da criação de meios de produção, de instrumentos para execução desse trabalho, temos que, na educação, por meio de sua função social, o trabalho educativo deve ser o de propiciar que o indivíduo se aproprie da cultura historicamente construída, como argumenta Paro (2007).

Nesse sentido, o coordenador pedagógico, que é um profissional fundamental na gestão da escola, tem o papel de agente propiciador das práticas de apropriação dessa herança cultural, ou seja, da educação, desenvolvendo seu trabalho de mediação com o professor, com o diretor, com o aluno e com outros agentes envolvidos na escola.

Esse profissional, por ser social e histórico, precisa ser consciente de quem é realmente na sociedade de classes que vive e trabalha. Ele precisa se entender e entender sua dimensão histórica e material por meio das relações contraditórias que se estabelecem entre os homens e os meios da produção da cultura. 
Da mesma forma, é um profissional que precisa se conhecer como um indivíduo real, que não depende apenas de sua vontade ou da vontade ilusória de agentes que dominam os saberes, caso contrário, estará respondendo apenas a uma demanda ideológica, pois: “Os homens são os produtores das suas representações, ideias, etc., mas os homens reais, os homens que realizam". (MARX, ENGELS, 2009, p.31).

Sendo um profissional da educação e tomado como sujeito e foco do curso analisado nessa pesquisa, ele é entendido em sua dimensão histórica e social, a qual é determinada por diferentes configurações da sua função ao longo de sua experiência de trabalho e pela relação direta com os objetivos pretendidos pelas instituições e pela estrutura da escola em que ele atua, bem como, com o próprio sentido que ele mesmo dá ao seu trabalho.

Essa perspectiva pauta-se na visão de um profissional que pode realizar seu trabalho a partir de uma prática social ou da práxis, como coloca Triviños (2006), que se refere a "uma atividade objetiva, material, fundamental, capaz de modificar a sociedade e a natureza". (p.127). Trata-se de um saber que é acumulado pelo ser humano através da história e que é construído pela unidade da prática com a teoria, considerando as relações estabelecidas pelos sujeitos e suas práticas diárias no contexto de mudanças sociais.

Dessa forma, o coordenador pedagógico, ao realizar sua prática pedagógica no cotidiano da escola, ao desenvolver sua prática materializada pelo seu trabalho como coordenador, pode desenvolvê-la por meio da unidade com a teoria, traduzindo-se nas ações desenvolvidas pela sua práxis.

Nesse sentido, o seu trabalho é uma forma de práxis, pois como discutimos no texto introdutório da tese, trabalho e práxis são categorias que estão diretamente relacionadas, tendo em vista que é da prática concreta do homem, conquistando e transformando a natureza, que nascem as ideias, os conceitos, a teoria, sendo esse homem considerado o "Ser da Práxis".

Diante desses apontamentos e baseando-se na visão de Gramsci, entendemos que esse profissional também é, ou pode ser, um intelectual orgânico, tendo em vista que ele faz parte de um sistema social que é vivo e está em constante movimento e que, unindo teoria e prática, pode contribuir para elevar a consciência dos professores, dos alunos, dos diretores, da equipe diretiva da escola e da sociedade de forma geral, a um nível mais coerente e homogêneo da classe que pertence a partir de um projeto hegemônico.

Então, são orgânicos os intelectuais que, além de especialistas na sua profissão, que os vincula profundamente ao modo de produção do seu tempo, elaboram uma concepção ético-política que os habilita a exercer funções culturais, educativas e organizativas para assegurar a hegemonia 
social e o domínio estatal da classe que representam. (SEMEARO, 1999, p.6).

Para entender melhor quem é esse profissional, passamos na sequência a apresentar um estudo bibliográfico que, embora não seja aprofundado, auxiliou na apreensão sobre as origens, a função, sobre aspectos da formação, sobre a identidade e outras características desse profissional.

\subsection{O Profissional Coordenador Pedagógico}

Questionamentos sobre quem é esse profissional, qual sua identidade no âmbito escolar, como suas práticas diárias podem ser referenciadas por meio de práticas sociais, entre outros, levou-nos a organizar as ideias aqui expostas a partir de uma pesquisa bibliográfica.

Cabe ressaltar que essas questões representam apenas um ponto de partida, pois como argumentamos anteriormente, consideramos que esses sujeitos e sua prática de trabalho no dia a dia fazem parte de uma totalidade que os envolve em um movimento que é histórico, político, social e, portanto dialético.

Nessa visão entendemos que ele é um sujeito da aprendizagem e do ensino no âmbito da escola e da sala de aula e como tal, é no seu processo de formação e de trabalho que também transforma a si mesmo e o meio em que atua a partir da convivência com outros sujeitos.

Como o coordenador pedagógico é um educador antes de tudo, seu objeto de trabalho deve propiciar relações pedagógicas necessárias para contribuir com a formação de seres humanos, o que é um papel social da educação. O produto de seu trabalho é a produção de seres humanos históricos que também se transformam enquanto sujeitos nas relações de aprendizagem.

Essa concepção se pauta na perspectiva ontológica de trabalho na visão dialética marxiana, que se refere, conforme anunciamos, a uma "atividade transformadora adequada a fins", na qual o indivíduo que a pratica, também se faz sujeito. (PARO, 2002). Trata-se de uma compreensão que diferencia o homem de qualquer outra espécie e lhe permite fazer mediação com outros homens e com a natureza.

A profissão do Coordenador Pedagógico no Brasil ainda carece de legislação específica. A respeito da sua origem, há autores, como Miziara (2008), Saviani (2002), 
Vasconcellos (2002), que a demarcam pela influência de suas funções à da supervisão escolar e, consequentemente, suas marcas de uma função burocrática e autoritária.

No que refere à supervisão, Vasconcellos (2002) lembra que ela promove no interior da escola a "divisão social do trabalho", na medida em que separa os que "pensam, decidem, mandam" daqueles que "executam". (p.86). Nesse sentido, o autor chama atenção para que a função do coordenador pedagógico seja reconstruída. "Em função dessa origem profissional ligada ao poder e controle autoritários, há necessidade de o coordenador, que assume uma postura diferenciada, conquistar a confiança dos educadores". (p.86).

Cada região do Brasil estabelece a função, a nomenclatura e as atribuições para os CPs, mas independente dessas formas, tomamos esse profissional da equipe diretiva da escola a partir do conceito mais amplo de Coordenador Pedagógico, já que sobre suas origens pela via da função da supervisão, é um profissional que acabou não construindo uma identidade própria.

Dessa forma, consideramos esse profissional como um educador que tem seu objeto de trabalho voltado para as relações pedagógicas, as quais precisam contribuir com a formação dos outros seres humanos. Tomando como referência a definição positiva dada por Vasconcellos (2002), de que o coordenador pedagógico/supervisor educacional é um sujeito articulador do Projeto Político Pedagógico e, portanto, tem a função de organizar a "reflexão, a participação e os meios para a concretização" desse projeto, temos que suas ações devem auxiliar que a escola também realize sua função social, propiciando que "todos os alunos aprendam e se desenvolvam como seres humanos plenos". (VASCONCELLOS, 2002, p.87).

Esse conceito é tomado como sendo positivo em detrimento do que esse autor chama de "definição negativa" do papel do supervisor/coordenador, mostrando elementos que descaracterizam essa função e que ainda são muito presentes nas relações educacionais atuais, o que impede que esse profissional tenha sua identidade afirmada e valorizada.

Assim, Vasconcellos (2002) destaca que o coordenador pedagógico NÃO é: fiscal de professor; dedo duro; pombo correio; coringa/tarefeiro/quebra galho/salva-vidas; tapa buraco; burocrata; dicário; de gabinete; generalista". (p.87).

A coordenação é exercida por um educador, e como tal deve estar no combate a tudo aquilo que desumaniza a escola: a reprodução da ideologia dominante, o autoritarismo, o conhecimento desvinculado da realidade, a evasão, a lógica classificatória e excludente (repetência ou aprovação sem aproximação do saber), a discriminação social na e através da escola, etc). (VASCONCELLOS, 2002, p.87). 
Por esses e outros motivos, o CP tem um importante papel na escola. Para além de sua formação se iniciar na pedagogia e ser continuada em cursos de pós-graduação, entendemos que ele, sendo um sujeito histórico e social, que se forma e se transforma ao longo de sua ação profissional e humana, deve-se reconhecer assim, afirmar-se e se impor para desenvolver seu trabalho independente das situações adversas que possa encontrar no espaço escolar.

Não podemos ignorar que as condições adversas ao seu trabalho no dia a dia da escola são muitas e, certamente, dificultam um trabalho mais pontencializador, porém acreditamos que esse profissional ao reconhecer-se como um importante profissional, participante da elaboração do PPP da escola, pode se articular melhor com os docentes, com a própria equipe gestora, pode propor ações, mediar situações, intervir para prevenir problemas, enfim, pode coordenar de fato as questões pedagógicas da escola.

Lima e Santos (2007), em pesquisa sobre o trabalho do coordenador pedagógico, apontam que existe um imaginário negativo, construído tanto pelos coordenadores, quanto pelos atores educacionais, sobre sua identidade e função, os quais passam a executar ações que não thes dizem respeito, mas executam porque na verdade não sabem o que deveriam fazer. Destacam os autores sobre os dados da sua pesquisa que perceberam "uma queixa unânime sobre a desorientação e quase perda de identidade profissional" (p.80).

Apontam que uma das dificuldades que esse profissional apresenta para realizar seu trabalho tem a ver com o campo em que ele atua, com a falta de clareza sobre o que deve fazer, o que o leva a fazer aquilo que ele dá conta, "por conta das crenças autorrealizadoras no interior da escola, acompanha o ritmo ditado pelas rotinas ali arraigadas". (LIMA, SANTOS, 2007, p.80).

Os autores destacam um continuun dimensional de conflitos vivido pelo $\mathrm{CP}$,

[...] o coordenador pedagógico tem constrangimento de sua autoridade porque confunde com autoritarismo, desta maneira, constrange-se em abordar questões evidentes que concorrem para um mau andamento do trabalho pedagógico, por isso se omite. Confunde a atribuição de seu papel profissional com imposições normativas, bem como democracia, autoridade e autoritarismo, ficando sem norte e não raras vezes com um sentimento de perda de identidade profissional intraescola. (p.81).

Miziara (2014) também destaca outro exemplo relacionado aos fatores que prejudicam os coordenadores a desenvolver sua função pedagógica, o qual tem a ver com a questão da estrutura educacional imposta pelas políticas neoliberais, sobretudo nos anos de 1990, as quais requerem novas posturas por meio de um trabalho mais flexível, ágil, eficaz e 
competente. Por isso, chama atenção para que o CP compreenda essas questões mais amplas de reestruturação do capital e as exigências para a educação e, consequentemente, exigências sobre o seu papel na escola, para que, de uma forma mais consciente, ele possa exercer suas funções.

A autora argumenta que os novos tempos requerem dos coordenadores, especialmente o da escola pública, consciência de que o neoliberalismo é um instrumento da política hegemônica do mundo capitalista, e que essa se encontra a serviço do mercado. Esse fenômeno reforça a ideia de privatização dos sistemas educativos como a solução para as alegações de crise de eficiência, eficácia e produtividade.

Nessa perspectiva, retomamos ao posicionamento de Gramsci ao postular que o intelectual orgânico tem um papel hegemônico importante para elevar as classes subalternas a uma consciência de sua classe e, como tal, precisa reunir forças para superá-la. Aguiar (1991) reconhece nessa perspectiva, que o supervisor pedagógico, no caso o coordenador pedagógico, pode ser um agente intelectual e integrante do "bloco ideológico" ou "bloco intelectual", o que, para a autora, "parece um caminho promissor para o entendimento da sua função e atuação no aparelho educativo do Estado". (p.48).

Considerando que a educação brasileira, ao longo de sua história, tem sido alvo de várias reformas, as funções dos profissionais da educação vão sendo ressignificadas de acordo com as intenções das políticas vigentes e dos governos que justificam a necessidade de criação de funções que complementem a função do professor.

Vimos que, pelas diretrizes dos OIs, há interesses de ordem econômica de forma que os bons gestores auxiliam para elevar o padrão de qualidade da educação, gerindo bens os recursos financeiros e os recursos do capital humano, de forma a alcançar um contingente de mão de obra competente e útil para o desenvolvimento econômico.

No Brasil, as reformas educacionais, desde os anos de 1990, materializam-se num contexto social e político marcado por profundas mudanças apoiadas por orientações internacionais que reconhecem o potencial inovador da educação para fazer frente aos anseios de formação de mão de obra especializada para o mercado produtor, sendo a educação o eixo pontencializador para o desenvolvimento econômico, para manter a ordem civil e para diminuir a pobreza.

Então, para além da ordem vigente que se impõe a racionalidade econômica e produtiva, o coordenador pedagógico, ao assumir uma posição de intelectual, precisa atuar também como mediador e veiculador das ideologias de seu grupo. Assim, tomemos a mediação como 
campo de atuação do CP, que segundo Vasconcellos (2002), é um fator determinante nas práticas desse profissional para auxiliar o seu trabalho pedagógico e o trabalho do professor em sala de aula, cuja tarefa de ensinar precisa estar conectada, sobretudo ao ensinar para a formação humana.

Por sua vez, a mediação pode ocorrer também, de acordo com o autor, nas ações do CP com o trabalho da própria administração escolar no sentido de fazê-la entender qual seja o objetivo e a função social da escola, assim como desenvolver também mediações das relações com a comunidade, num processo contínuo de aprendizagem. "É possível afirmar, portanto, que a especificidade da atuação da coordenação pedagógica são os processos de aprendizagem, onde quer que ocorram". (VASCONCELLOS, 2002, p.90).

Se o CP é um sujeito que faz parte da administração escolar, que é membro da equipe diretiva, então concordamos com Vasconcellos (2002) e com Paro (2002), que esse profissional tem um caráter mediador das relações pedagógicas e administrativas e, portanto, não pode se restringir a um papel de controle do trabalho alheio, mas sim ser um agente democrático para desenvolver ações também democráticas.

Paro (2002), ao abordar sobre o conceito mais amplo de administração escolar, ressalta que ela trata da "utilização racional de recursos para a realização de determinados fins". Como o coordenador pedagógico lida também com as relações sociais, certamente ele também deve lidar com as relações democráticas, como argumenta o autor que "não é possível alcançar fins promotores da democracia e da afirmação de sujeitos históricos" que não sejam também os democráticos. (p.17).

Dessa forma, ao considerar algumas questões necessárias para haver mudanças nas práticas dos coordenadores tendo em vista a amplitude de sua identidade e ação, e considerando práticas mais democráticas, Vasconcellos (2002) reconhece que, por resistência, desânimo ou mesmo pela falta de entendimento de seu papel, muitos não agem para mudar o que está instituído na escola, apenas agem para continuar o que já está em desenvolvimento.

Assim, para mudar, ele precisa de condições objetivas e subjetivas, nas quais a coordenação pedagógica deve ser "capacitada nas três dimensões da formação humana" que são a "conceitual, procedimental e atitudinal". (p.90).

Em relação a essas três dimensões da formação humana, Vasconcellos (2002) argumenta que a atitudinal é considerada como uma das mais difíceis de ser conseguida, pois se trata das relações que envolvem "caráter, valores, interesses, sentimentos" em que os professores podem se esconder e se fechar para o diálogo. 
No entanto, o CP precisa ajudar o grupo a encontrar o caminho, desenvolvendo relações de empatia, de confiança e transparência. Nessa dimensão, Vasconcellos (2002) destaca alguns princípios norteadores ao trabalho do CP para que ele consiga analisar as ações dos professores e intervir sobre elas, dentre eles destacam-se a "criticidade", "historicidade" e a "totalidade".

$\mathrm{Na}$ dimensão procedimental, o foco está na relação do saber-fazer e, para tanto, as categorias de intervenção, de sustentação e estratégias complementares ao trabalho do CP podem ajudar os professores. E na dimensão conceitual, o autor destaca as concepções de mundo, de homem e de educação que cada indivíduo carrega consigo e que a compreensão ou a falta da compreensão teórica podem acarretar vários problemas. Nesse sentido, o CP pode ajudar na construção de um "método de conhecimento" de forma que auxilie o professor a pensar, repensar e descobrir melhores maneiras de o aluno aprender.

Quanto às condições mais objetivas para a ação da coordenação pedagógica, Vasconcellos (2002) aponta uma série de questões que, refletidamente, podem auxiliar o trabalho desse profissional, dentre elas destacamos: a busca de melhores condições de trabalho na escola; a conquista do espaço de trabalho coletivo; o acompanhamento individual e sistemático; a constituição de grupos de formação; a organização de grupos de estudos; a luta pela continuidade crítica das políticas educacionais, dentre outras.

Esses elementos apontados por Vasconcellos (2002) são importantes caminhos para uma melhor atuação do $\mathrm{CP}$, tendo em vista redirecionar seu trabalho para propiciar relações pedagógicas necessárias de forma a contribuir para que a escola possa proporcionar a formação de seres humanos históricos. É nesse sentido que o produto do seu trabalho é a produção de sujeitos que se transformam, enquanto sujeitos nas relações de aprendizagem, o que faz com que o próprio CP também se modifique ao longo de suas ações reflexivas e práticas.

Esse processo certamente contribui também para a construção e afirmação da identidade do profissional da coordenação pedagógica que, como destacam Lima e Santos (2007), é uma "prática em que se busca o significado do papel e exercício da cidadania e da própria humanidade". (p.83).

A identidade de qualquer profissional se constrói cotidianamente e no conjunto das relações, no exercício de sua função a partir das necessidades concretas do dia a dia da escola, em convivência com outros sujeitos, mas que se transforma a partir de um objeto comum de educação, exigindo planejamento, organização e utilização de meios adequados para se 
alcançar os fins desejados. "Assim a coordenação pedagógica, exercida por um educador, guarda as suas bases fundamentais no significado e papel da educação". (LIMA, SANTOS, 2007, p.84).

Concordamos com esses autores os quais apontam que a identidade do CP se constrói na ação e na reflexão de suas ações, e que, portanto, não se desenvolve sozinha, mas sim em meio aos relacionamentos, às trocas e vivências com os professores, diretores, orientadores, alunos, pais e tantos outros colaboradores da escola. Vale dizer que nesse processo ocorre a formação e a transformação do CP e dos outros sujeitos envolvidos.

Não se trata de um trabalho individualizado, nem competitivo, ou apenas técnico, mas de um trabalho coletivo e humano que é desenvolvido em um processo que demanda tempo de qualidade na convivência, na reflexão e na construção e desenvolvimento dos projetos. Assim, a "ação coletiva de administração dos conflitos e encaminhamentos poderá ter um direcionamento mais coeso e prudente, respondendo sem omissão às recorrências da escola e de seus pares, quer sejam políticas, profissionais e/ou de outra índole”. (LIMA, SANTOS, 2007, p.85).

Vale ressaltar que sendo o $\mathrm{CP}$ um sujeito histórico, precisa transcender a tudo o que existe fora da sua vontade e de sua ação por meio da produção de sua própria existência material, a partir do momento em que "afirma sua vontade, expressa nos valores por ele criados historicamente", (PARO, 2002), ou seja, a partir de atividades transformadoras pelo seu trabalho, que são feitas na convivência com outros sujeitos.

\begin{abstract}
Nesse processo ele se faz sujeito (característica distintiva de sua humanidade), no preciso sentido do autor, de quem atua sobre o objeto para realizar sua vontade, expressa nos valores por ele criados historicamente. Mas esse processo jamais pode ser concebido isoladamente, posto que o homem só se realiza, só pode produzir sua materialidade, a partir do contato com os demais seres humanos [...] mediada pela divisão social do trabalho. (PARO, 2002, p.15).
\end{abstract}

Na medida em que o ser humano se faz um sujeito histórico, ele também se faz um ser político, pois ao conviver com os outros, ao fazer educação com os outros, está exercendo atitudes políticas, sendo estas entendidas no seu conceito mais amplo de uma atividade humana-social com o propósito de tornar possível a convivência entre grupos. Nesse sentido, a educação, que busca a produção de sujeitos, é política e democrática. (PARO, 2002).

Diante desses apontamentos, expressamos o entendimento que o CP é muito importante para as relações pedagógicas da escola, da sala de aula e do convívio com a 
comunidade escolar, como bem ressaltado, por exemplo, no documento PPP do MEC (2009), sobre a criação do curso de especialização em coordenação pedagógica no âmbito do PNEGEB, o qual reconhece que o CP "sendo um membro da equipe gestora da escola, desenvolve importante papel de articulador e integrador dos processos educativos". (p.5).

A partir dessa visão mais discursiva do documento e de tantas outras que vamos analisando ao longo desta pesquisa, buscamos entender como o curso proporcionou, ou não, elementos teórico práticos para a formação dos $\mathrm{CP}$, de modo que em seu trabalho diário, consegue ou não desenvolver a articulação e a integração dos processos educativos.

O documento de Diretrizes do PNEGEB (2009) também evidencia que as ações em torno das políticas de formação de profissionais gestores da educação, devem proporcionar uma formação efetiva de modo que os gestores “disponham de elementos teórico-práticos que viabilizem uma educação escolar básica com qualidade social" e que esteja baseada nos princípios da gestão democrática, tendo por eixo "a escola como espaço de inclusão social e da emancipação humana". (p.7).

Esses princípios emanados dos documentos oficiais são também esperados por educadores que ao longo da história da educação no Brasil tem lutado em busca de uma formação adequada para os profissionais da educação, assim como também, é o anseio dos próprios coordenadores pedagógicos, egressos do curso pesquisado e que, por sua vez, declararam, na grande maioria, que o curso os ajudou no fortalecimento da educação inclusiva e da gestão democrática e que, no seu trabalho diário, passaram a desenvolver ações mais democráticas e participativas.

Sabemos que construir um ambiente democrático não é tarefa fácil, mas é indispensável nas atribuições do coordenador pedagógico, tendo em vista que ele é um mediador das relações pedagógicas na escola e fora dela. Essas relações, contrárias ao posicionamento autoritário e coercitivo das origens de suas funções, devem ser alcançadas por meio do diálogo, da persuasão, da prática do saber falar e ouvir, do respeito ao próximo, do incentivo à participação e do debate, num movimento de aprendizagem e formação contínua e compromissada com a formação humana.

Reafirmamos mais uma vez que, nesse processo, o CP atua na dimensão de sua transformação enquanto sujeito histórico, por meio do seu trabalho de mediação e ao mesmo tempo, colabora para a (trans) formação de outros indivíduos e do próprio meio em que atua. Espera-se, contudo, que esse processo democrático seja coerente na sua formação inicial, 
continuada, no seu trabalho diário, que seja de fato vivido e experienciado na sua dimensão mais profunda.

Compreendidas essas questões que situam e demarcam o sujeito constituinte do objeto de estudo em suas múltiplas determinações sociais, políticas e históricas, passamos na sequência a situá-lo a partir dos referenciais empíricos.

\subsection{Os Participantes da Pós-graduação em Coordenação Pedagógica}

Como mencionamos anteriormente, os participantes da pesquisa e respondentes do questionário foram os egressos (os coordenadores participantes do curso), os professores do curso e o gestor geral. Os egressos participantes somam um total de 299 aprovados e, portanto, esse foi o número considerado para a aplicação dos questionários. Os professores que atuaram no curso somam 35, além de dois gestores. Os respondentes foram 82 egressos, 15 professores e um gestor.

Retomando as premissas relacionadas aos documentos do MEC a respeito da criação da política de formação de gestores escolares no Brasil (PNEGEB), vemos que eles retratam, de forma geral, o reconhecimento de que o país precisa alcançar as metas educacionais que foram estabelecidas desde os anos de 1990, nos pactos de educação como nas Conferências e Encontros Internacionais, os quais visam promover ações para uma educação de qualidade para todos, conforme discussão feita no Capítulo II.

Interessante pontuar que, desde o documento inicial do MEC em 2004, o Projeto Básico do Programa Escola de Gestores, perpassando pelo documento de Diretrizes Nacionais do programa em 2009 e o documento específico de criação do Curso de especialização em Coordenação Pedagógica em 2009, percebemos uma ênfase sobre a formação de profissionais da gestão educacional, pautada em discursos de valorização e investimentos para esses profissionais.

Vemos também uma responsabilização colocada a esses profissionais de modo que eles sejam capazes de desenvolver um novo modelo de gestão mais eficaz e que resulte na melhoria da qualidade da educação considerando a perspectiva da gestão democrática. Por um lado, essa ênfase recai sobre os consensos estabelecidos pelos OIs.

Por outro lado, são demandas que se coadunam com os interesses e perspectivas de educadores brasileiros, como lembra Gracindo (2009), ao destacar o fato de que essas novas demandas, para se alcançar posturas mais democráticas na escola, requerem dos gestores 
escolares também novas práticas democráticas. Nesse sentido a autora reconhece que a formação dos gestores perpassa pela formação da docência cujo caráter político e pedagógico deve ser estabelecido tendo em vista garantir que esses profissionais desenvolvam uma postura crítica e democrática.

Considerando o pressuposto de que o coordenador pedagógico é entendido a partir de sua dimensão histórica que é determinada por diferentes configurações de sua função ao longo de sua experiência de trabalho, concordamos com Gracindo (2009) quando afirma que a formação continuada para gestores escolares deve ser vista com uma "possibilidade de o gestor estar em constante movimento de aprendizagem [...] por meio de apropriação dos avanços obtidos na área e desenvolvidos, tanto em ações presenciais, como pela mediação das diversas tecnologias de informação e comunicação (TIC) disponíveis”. (p.143).

A partir dessa referência e considerando que o CP se torna esse profissional a partir de um processo que é dinâmico, buscamos conhecer o coordenador ou profissional da equipe diretiva que realizou a pós-graduação no curso de especialização em Coordenação Pedagógica ofertado pela UFT e seus parceiros no período de 2010-2011.

Os egressos na sua grande maioria são do sexo feminino, com faixa etária variando entre 30 a 50 anos. Possuem formação inicial em curso de pedagogia ou em o curso normal superior, sendo em grade parte realizado em curso presencial.

Com relação à formação continuada, 53 egressos informaram que já haviam realizado outra especialização lato sensu e três possuíam curso de mestrado. $\mathrm{Na}$ opção "Outros" do questionário, 26 egressos mencionaram já ter realizado ou estar realizando outro tipo de pósgraduação lato sensu em áreas diversas, por exemplo, na orientação educacional, gestão escolar, gestão de recursos públicos, educação infantil, planejamento educacional, físiologia do exercício, história do Brasil e em psicopedagogia.

Especificamente, sobre o curso de Coordenação Pedagógica, considerando-o como um investimento na formação continuada, fizemos afirmativas para que os egressos refletissem se ele foi um curso que lhes auxiliou a suprir deficiências da formação inicial e se respondeu aos anseios da formação continuada.

De forma geral, a maioria dos egressos concordou que o curso supriu suas deficiências da formação inicial e que o curso respondeu às suas necessidades e anseios de formação continuada em relação à coordenação pedagógica, como vemos pelas respostas organizadas na Tabela 2. 
Tabela 2 - Auxílio para a formação inicial e continuada

\begin{tabular}{l|c|r}
\hline & \multicolumn{2}{c}{ Quant. } \\
\hline Supriu deficiências da minha formação inicial (graduação) & 1 & 1,22 \\
\hline Discordo Plenamente & 3 & 3,65 \\
\hline Discordo & 8 & 9,76 \\
\hline Indiferente & 46 & 56,10 \\
\hline Concordo & 24 & 29,27 \\
\hline Concordo Plenamente & 1 & 1,22 \\
\hline Respondeu às minhas necessidades e anseios de formação em coordenação pedagógica \\
\hline Discordo Plenamente & 1 & 1,22 \\
\hline Discordo & 3 & 3,65 \\
\hline Indiferente & 45 & 54,88 \\
\hline Concordo & 32 & 39,02 \\
\hline Concordo Plenamente & &
\end{tabular}

FONTE: SOUZA, Raquel A. Pesquisa de doutorado, 2016.

Esses olhares ratificam as reflexões de autores que se mostram contrários ao fato de a formação inicial dos profissionais da educação ocorrer apenas em cursos que formam para a docência, como é o caso da Pedagogia.

Autores como Franco (2008), Aguiar et al (2006), Placco, Almeida e Sousa (2010) acreditam que esses cursos não têm proporcionado todos os elementos necessários para que esses profissionais desenvolvam bem suas funções.

Placco, Almeida e Sousa (2010), ao reconhecerem que o objeto de ação do coordenador é diferente do professor, argumentam que a formação para coordenadores somente para a docência, como é o caso do curso de Pedagogia, por mais que tenha sido reconfigurado passando a ter uma formação mais abrangente "não garante o desenvolvimento de habilidades e competências para o exercício da coordenação pedagógica”. (p.120).

No relatório da pesquisa realizada por esses autores em 2011, eles destacam:

Essa formação necessitaria levar em conta que esse profissional precisa ter
competência para articular, formar e transformar, diferentemente do
professor, cuja especificidade é o ensinar. Logo, visto que o objeto de ação
do CP é diferente daquele do professor, a formação para a docência não
garante o desenvolvimento de habilidades e competências para o exercício
da coordenação pedagógica. Ter clareza a esse respeito contribuiria para a
constituição da identidade profissional do CP, tendo em vista que a
diferenciação entre as duas funções seria objeto dos cursos de formação, o
que possibilitaria identificaçôes com aspectos específicos da função.
(PLACCO, ALMEIDA, SOUZA, 2011, p. 120).

Para além dessas posições, apreendemos que investir na própria formação, por meio da formação continuada e em serviço, torna-se um ponto de partida para a busca de melhoria da 
profissão e ressignificação das próprias práticas de trabalho e como vemos, os egressos do curso analisado sinalizam esse interesse pela formação continuada.

No entanto, é preciso questionar quais as motivações para tal interesse, pois os OIs e as reformas educativas também têm reforçado por meio de seus consensos que, de fato, os profissionais da educação precisam se responsabilizar pela sua profissionalização a qual tem impacto direto na formação dos alunos e no desenvolvimento econômico.

Na concepção da Política Oficialmente Declarada - POD, compreendemos que essa visão trata de uma formação que contribuirá para "a sociabilidade demandada pelo capital com prioridades e itinerários formativos indicados pelos organismos multilaterais". (SHIROMA, 2011, p.17).

Como discutimos no Capítulo II, aos profissionais da educação são atribuídas todas as mazelas e problemas pela má qualidade da educação e essa aparece como uma das principais justificativas para a formação desses profissionais, o que tem sido elemento constante das reformas educacionais desde os anos de 1990 e que permanece em tom de continuidade até os dias atuais, apoiadas por políticas de profissionalização baseadas na busca por excelência, eficácia, competência, méritos aferidos por avaliações de desempenho, evidenciando o que Veiga (2003) coloca a respeito da inovação regulatória e técnica das políticas educacionais.

Diante dessa perspectiva de compreensão sobre quem foram os coordenadores participantes do curso analisado, buscamos compreender também sobre o perfil profissional. Indagamos sobre a função que eles exerciam na época da realização do curso (2010-2011) e a função que exercem atualmente (2015-2016), momento da participação na pesquisa, visando apreender se eles se mantiveram nas suas funções após a realização do curso.

As respostas dos egressos, como percebemos pelo Gráfico 3, demarcam que durante a realização do curso, uma expressiva quantidade deles atuava na função de coordenação pedagógica. Após quatro anos da realização do curso, vemos que menos da metade dos egressos continuaram nessa função nas escolas públicas do Tocantins. 
Gráfico 3 - Função do egresso - exercida na época do curso e após o curso.

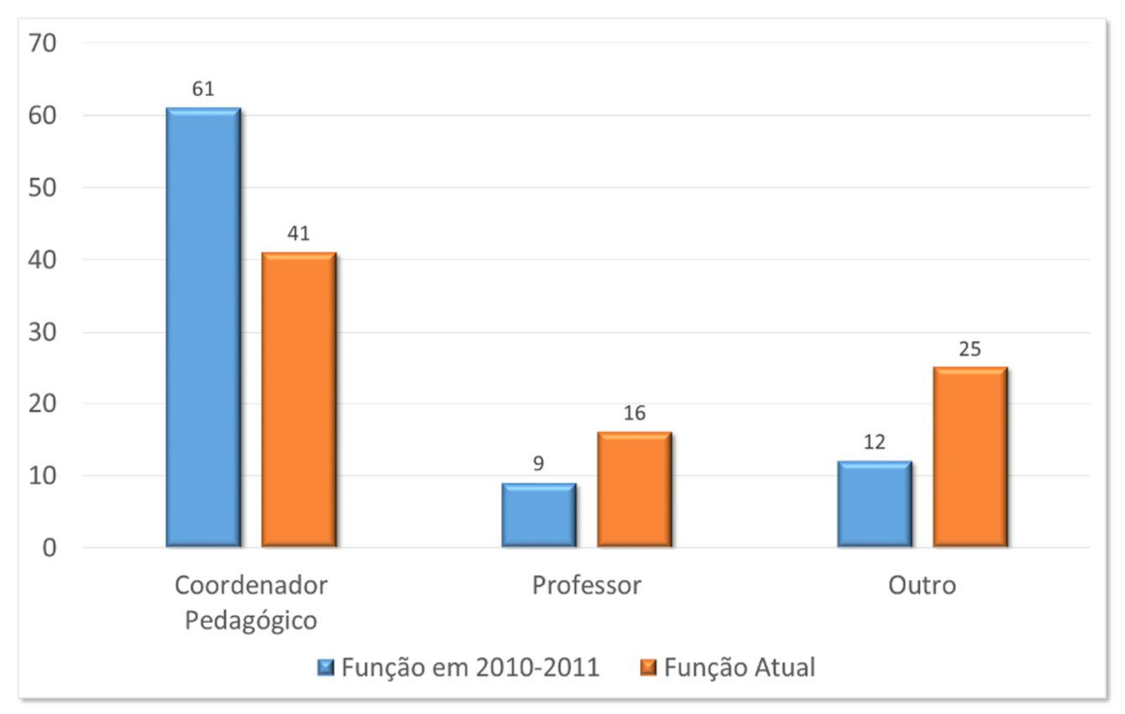

FONTE: SOUZA, Raquel A. Pesquisa de doutorado, 2016.

Em relação à função de professor, vemos que, na época de realização do curso, pelo menos $9 \%$ dos participantes eram docentes e $12 \%$ atuavam em outra função, como foi registrado na opção "Outros" em que eles informaram atuar também em funções como a de suporte pedagógico, supervisor educacional, supervisor de ensino, direção, coordenação de convênio.

Após o curso, vemos que $16 \%$ passaram a atuar na docência e 25\% assumiram outras funções, como as de técnico em educação, coordenação de convênios educacionais, diretor ou vice-diretor, dirigente municipal, assessor de programas e projetos, orientador educacional, assistente administrativo, coordenador de apoio, coordenador de políticas educacionais, auxiliar de secretário, auxiliar de coordenação, além de um registro de aposentadoria.

Comparando os dados da atuação profissional atual com a função exercida durante a realização do curso, percebemos que a maior quantidade de profissionais atuava na coordenação pedagógica e que isso mudou após quatro anos do curso.

Essa questão pontua que a condição de uma formação específica para a área da gestão educacional não indica que o profissional formado irá se manter na função ou, até mesmo, que fará o ingresso nela, assim como indica que o investimento público, a partir de políticas para formação de gestores, nem sempre resultará em formar profissionais que atuarão na função por muito tempo, pois se trata de uma função em que a rotatividade de profissionais é muito grande.

Vasconcellos (2012) chama atenção para essa questão da rotatividade dos profissionais da educação, considerando que esse é um fator negativo para que a escola e a educação 
desenvolvam sua função social e afirma a necessidade do fortalecimento da coordenação pedagógica que respeite um período de tempo que seja suficiente ao desenvolvimento do projeto do CP. Nesse sentido, concordamos que o investimento de cursos de formação para profissionais da educação precisa levar em consideração a questão da permanência ou não deles nas suas funções.

Se a intenção é contribuir para fortalecer a gestão democrática das escolas públicas, como assinalam os documentos oficiais do PNEGEB, então as políticas instituídas para formação dos profissionais devem considerar, junto ao investimento da formação, a questão do acesso e da permanência desses profissionais nas suas funções, para que, em tempo hábil, possam desenvolver seu trabalho pedagógico e seus projetos, considerando que os indivíduos são seres históricos e fazem parte de um processo social que está em permanente mudança, portanto são profissionais que necessitam de tempo de qualidade para que possam refletir e agir na perspectiva da prática social.

Considerando o fator tempo de experiência na educação, questionamos os egressos a respeito do tempo em que eles atuaram na função de $\mathrm{CP}$ e na função de professor e como percebemos pelo Gráfico 4, o maior tempo de experiência se refere à função de professor, quando 24 egressos afirmaram ter mais de 20 anos de experiência nessa função.

Gráfico 4 - Tempo de experiência na docência e na CP

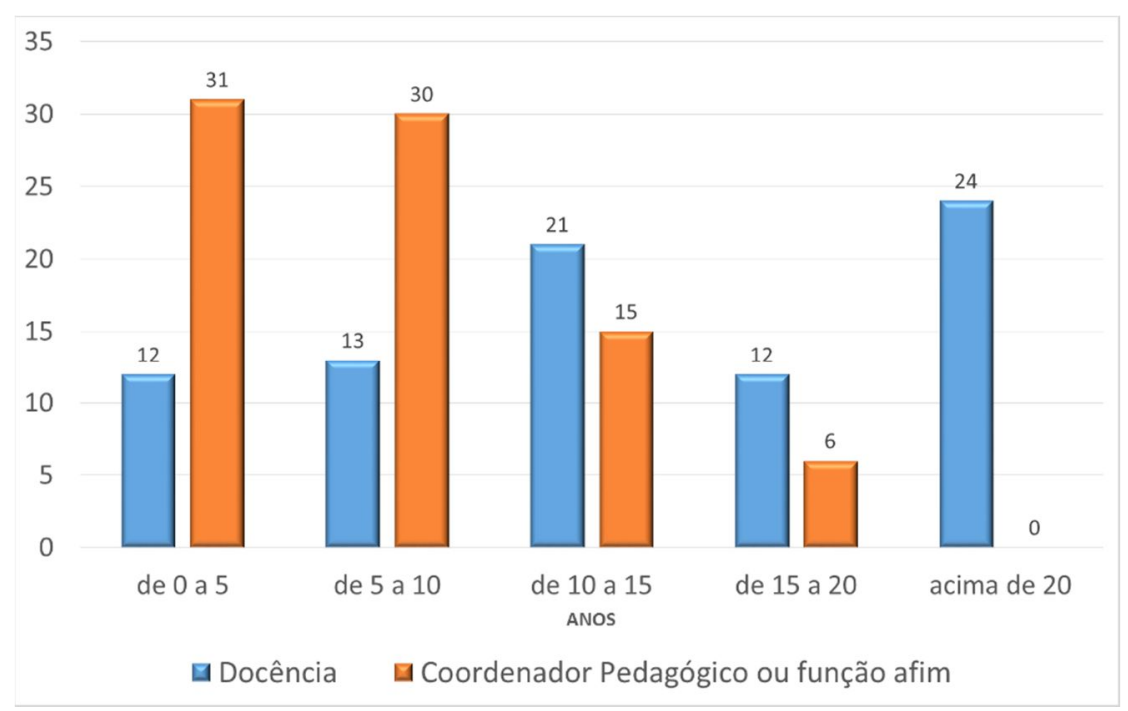

FONTE: SOUZA, Raquel A. Pesquisa de doutorado, 2016.

Com relação à experiência na função de coordenação pedagógica, observamos que o maior tempo de experiência se refere ao quantitativo de apenas seis egressos que afirmaram 
atuar na função de 15 a 20 anos, sendo que a maioria deles tem menos de 10 anos de experiência nessa função.

A pesquisa de Placco, Almeida e Souza (2011) sobre o CP no Brasil também aponta que o tempo de atuação desses profissionais nessa função, nas regiões pesquisadas, variava em até cinco anos, também destacam que o tempo na função e a experiência profissional são valorizados por todos os participantes, os quais "consideram que é no exercício da coordenação que se aprende a coordenar". (p.45).

Não podemos ignorar que os problemas sobre a permanência ou não dos profissionais da educação aos cargos de gestão educacional estão associados às práticas políticas de mando e desmando, típicas de uma sociedade com características patrimonialistas e clientelistas como é o caso do Brasil. Como discutimos no Capítulo I sobre a formação do Estado brasileiro e suas reconfigurações mais atuais, embora haja a busca por novas formas de gestão na perspectiva gerencialista para se obter mais eficiência e eficácia, conforme discursos da reforma gerencial, ainda prevalecem marcas das características patrimoniais e burocráticas.

Fausto (1995) argumenta, por exemplo, sobre essas características, que em tempos de eleições interessa aos partidos obter prestígios e benefícios para si e para os partidários, e para tanto, são comuns as práticas de concessão de favores aos amigos, pois o que está em jogo são os interesses de um grupo hegemônico que busca reproduzir os consensos desse grupo ou fração dele.

Sobre essas questões, perguntamos aos egressos sobre como eles assumiram a função de coordenadores pedagógicos em suas escolas. A maioria dos respondentes (70\%) afirmou que assumiu a função por meio da prática de indicação, seja pela escola ou pela Diretoria Regional de Ensino. Os outros $30 \%$ dos egressos apontaram outras formas de ingresso ao cargo.

Considerando os objetivos do curso analisado, segundo seus documentos oficiais, a formação oferecida aos coordenadores pedagógicos prescinde que eles possam auxiliar no desenvolvimento da gestão democrática da escola. Nesse sentido, concordamos com Gracindo (2009) ao pontuar que, dentre as exigências para o desenvolvimento da gestão democrática, é preciso também dar atenção à forma pela qual as instituições educacionais escolhem seus professores/gestores.

Dessa forma, a proposição da política pelo PNEGEB a partir da Política Oficialmente Declarada - POD, apresenta-se coerente aos anseios da sociedade, no entanto não é o que representa a materialidade dessa política quando evidenciamos por meio das vozes dos 
egressos que apontam as condições em que assumem as funções pelas práticas de escolhas para os cargos de gestão.

Gracindo (2009) reconhece que no Brasil, ainda vigoram formas diversas de escolha desses cargos e funções:

Indicação feita pelo chefe do poder executivo local, parlamentares da região e dirigentes educacionais, recaindo sobre pessoas que, mesmo não tendo vínculos diretos com a educação, assegura-lhes apoio político-partidário; o concurso público, por meio do qual é identificada, em exame de seleção, a capacidade técnica dos futuros gestores; a eleição direta, realizada pelos segmentos escolares e comunidade local, por meio do voto; e algumas formas mistas de escolha, que conjugam dois ou mais desses critérios. (p.138). (grifos do autor).

Retomando as Diretrizes Nacionais do Curso de Pedagogia, vemos que elas reconhecem que todo profissional da educação que tenha uma formação mais ampla na pedagogia, pode atuar "na gestão de processos educativos e na organização e funcionamento de sistemas e instituições de ensino”. (BRASIL, DCN/CP, 2006).

Nesse sentido, se apresenta coerente o fato de alguns egressos se mostrarem insatisfeitos com as práticas de indicação política para a função de Coordenação Pedagógica, sendo que, em algumas escolas do Tocantins, assumem a função aqueles profissionais que não têm a formação inicial apropriada, nem mesmo curso de formação continuada em nível da pós-graduação.

Esses elementos ficam perceptíveis pelo registro de alguns egressos na opção "Outros" do questionário, quando indagados sobre como se tornam coordenadores pedagógicos. O EG1 registra: “Através de indicação política. A formação não é um critério. Na minha escola, por exemplo, um professor de área deixa a sala de aula a qualquer momento e se torna coordenador, por intermédio de indicação". (EG1).

Outro egresso também registra seu descontentamento registrando que é: "Uma pena que não exerço a função de coordenador. Na minha cidade o cargo de coordenador está sendo sucateado por políticos". (EG2).

No Relatório Final do Curso da UFT, essa questão também é apontada como um dos problemas encontrados na realização do curso:

Outro problema que prejudicou bastante o andamento do curso foi o grande número de troca de coordenadores, principalmente na rede estadual [...] Além disso, outro fato causou uma repercussão negativa ao final do curso, foi informação de que a gestão estadual pretendia colocar na função de 
coordenador pedagógico exclusivamente os professores formados em Pedagogia. (p.13).

Embora as discussões mais críticas sobre a escolha de dirigentes escolares tenham como referenciais teóricos estudos em torno do cargo de diretores, convém ressaltar que a forma como a escolha dos outros atores da gestão é feita, também deve expressar o desenvolvimento de práticas democráticas e não autoritárias, patrimonialistas ou políticopartidárias.

Tendo em vista que o curso analisado visa contribuir com a formação de professores/coordenadores pedagógicos que possam auxiliar as escolas com práticas mais democráticas, espera-se que essas escolas, ao fazerem as escolhas dos gestores, também adotem posturas democráticas e que o curso de formação também auxilie nesse sentido, como é postulado nos documentos oficiais de criação do PNEGEB e do próprio curso analisado, apresentam como justificativas para sua implantação.

Em respostas livres das opções "Outros" do questionário, selecionamos alguns apontamentos feitos pelos egressos que indicaram que, após quatro anos da realização do curso, ainda não tiveram a oportunidade de assumir a função de $\mathrm{CP}$ e, nos casos que até conseguiram, desenvolvem a função, mas continuam a receber como professores. Nesse sentido, vemos até expressões de desesperança para realização de cursos de pós-graduação.

EG 4 - Foi uns dos melhores cursos que fiz, porém continuo na coordenação de convênios na SME. Assim, ainda não foi possível realizar um trabalho como Coord. Pedagógica.

EG 5 - O Curso foi ótimo, mas a SEDUC não garantiu ate hoje nossos salários como coordenadoras, recebemos como professor diferentemente de outros Estados, mas na prática estamos utilizando muita coisa.

EG 6 - O fato é que não temos estímulo nenhum em fazer uma pósgraduação. Por nada. Sou uma professora que amo meu trabalho, mas como muitos outros, desacreditada com os rumos que a educação tem tomado.

Certamente, essas vozes e outras não reveladas pelos participantes do curso demonstram a necessidade da continuidade e aprofundamento dos estudos sobre a formação continuada e a distância, pois de forma contraditória, vemos que, ao mesmo tempo em que elas expressam que os objetivos do curso foram alcançados, mostram vozes que as contradizem. 


\subsubsection{O Interesse, Dedicação e Ingresso na Pós-graduação}

O Projeto Pedagógico do Curso apresentado pela UFT aponta que os participantes deveriam organizar seu tempo entre o trabalho profissional e a vida pessoal para se dedicarem ao curso, considerando as características específicas do curso na modalidade EaD. Diante desse posicionamento, fizemos questionamentos aos egressos para que refletissem sobre o interesse e a dedicação ao curso, de forma a compreendermos o envolvimento e as dificuldades encontradas para sua permanência nessa pós-graduação.

Dentre as questões norteadoras desse eixo de análise, questionamos sobre a carga horária de trabalho; saber como foram informados sobre o curso; quais os motivos para realizá-lo; qual a faixa salarial e qual a distância física compreendida entre a residência e a cidade polo do curso. Importante ressaltar que, associado a esse item sobre dedicação dos cursistas, também fizemos questionamentos aos professores do curso a fim de apreender suas opiniões.

Questionamos os egressos sobre a carga horária de trabalho que tinham na época da realização do curso, considerando que o PPC exigia uma dedicação de pelo menos 10h semanais. A maioria dos egressos afirmou que dispunham de tempo suficiente para se dedicar ao curso, como percebemos pelas respostas de $82 \%$ dos que informaram ter uma carga horária de trabalho semanal que variava entre 20 e 40h. Esses dados apontam possibilidades positivas no que se refere ao fator tempo para a dedicação ao curso.

A opinião de $70 \%$ dos professores sobre a dedicação dos cursistas foi de uma dedicação positiva, os quais reforçaram que, mesmo diante de alegações de alguns cursistas por falta de tempo, eles consideram que a maioria conseguiu se dedicar bem ao curso.

No entanto, os outros $30 \%$ dos professores não concordaram que os cursistas tenham se dedicado nem o mínimo de $10 \mathrm{~h}$ semanais, justamente porque alegavam a falta de tempo. Em decorrência dessas discordâncias dos professores, vemos que um pequeno quantitativo de egressos reconheceu que teve dificuldades em relação a esse fator tempo para se dedicar ao curso.

Esses dados corroboram os apontamentos do Relatório de Avaliação do Curso, no item sobre a utilização do Memorial Reflexivo (MR), um dos instrumentos de avaliação utilizados na pós-graduação, no qual o cursista tinha liberdade para refletir e escrever sobre seu aprendizado, as dificuldades encontradas e fazer sugestões ou comentários sobre o curso. 
O Relatório em questão destaca trechos de MRs sobre o sentimento de cursistas em relação à dedicação ao curso, tendo em vista suas reflexões em torno das dificuldades encontradas:

A maior dificuldade enfrentada diz respeito à adequação pessoal do tempo disponível para estudo. Enfrentando uma realidade de 50 horas semanais de trabalho, exige-se muita disciplina para que o aproveitamento seja o melhor possível, que toda a bibliografia obrigatória, bem como complementar seja bem estudada e que contribua efetivamente para o crescimento profissional. (CURSISTA 10). (UFT, RELATÓRIO DE AVALIAÇÃO DO CURSO/CP, 2012, p.33).

Enfrentei muitas dificuldades nesse período. A primeira foi em relação ao próprio trabalho na escola, pois estive muito sobrecarregada. Às vezes eu ficava até as $2 \mathrm{~h}$ da manhã para poder terminar as atividades [...] Outra dificuldade foi em relação ao tempo para entrar nos fóruns e discutir. Às vezes nos intervalos das aulas, às vezes participei de madrugada. [...] (CURSISTA 11). (UFT, RELATÓRIO DE AVALIAÇÃO DO CURSO/CP, 2012, p.33).

A partir desses trechos, percebemos a confirmação de pelo menos $16 \%$ dos egressos que afirmaram que trabalhavam mais de 40h semanais durante a realização da pós-graduação, como pontuou o Cursista 10 e também pela colocação do Cursista 11 que demarca dificuldades sobre o tempo, quanto destaca que para acompanhar o curso, tinha que organizar seus estudos de madrugada, o que demonstra, que dadas às condições adversas de cada um, eles demonstraram interesse e esforços para realizar e permanecer no curso.

As percepções dos $30 \%$ dos professores que não concordam que os cursistas tenham se dedicado tão positivamente ao curso, também corroboram outro trecho do mesmo Relatório de Avaliação, onde se registra: "Outra dificuldade bastante enfatizada pela maioria dos cursistas é em relação ao fator 'tempo', que impacta diretamente no desenvolvimento da aprendizagem e na qualidade do curso". (UFT, RELATÓRIO DE AVALIAÇÃO DO CURSO/CP, 2012, p.32).

Quando questionamos os egressos a respeito dos motivos que os levaram a realizar o curso, pelo menos a metade deles apontou que apenas buscava melhorias para sua formação, enquanto a outra metade indicou que o interesse pelo curso estava ligado tanto em relação à perspectiva de melhorar a formação, quanto também, de melhorar o salário.

Sobre a faixa salarial, a maioria dos participantes demonstrou receber entre 4 a 8 salários mínimos, como visualizamos na Tabela 3, o que equivale ao ano de 2016 a aproximadamente entre $\mathrm{R} \$ 3.500$ a 7.040 reais. 
Tabela 3 - Faixa salarial

\begin{tabular}{l|c|c}
\multicolumn{1}{c}{ Salário pela função exercida } & Quant. & \% \\
\hline de 1 a 4 salários mínimos & 35 & 42,7 \\
\hline de 4 a 8 salários mínimos & 46 & 56,1 \\
\hline Acima de 8 salários mínimos & 1 & 1,2 \\
\hline
\end{tabular}

FONTE: SOUZA, Raquel A. Pesquisa de doutorado, 2016.

Embora essa questão não tenha contemplado a opção "Outros" para que os egressos pudessem manifestar suas opiniões em torno da relação dos salários com as funções desempenhadas, sabemos que se trata de um elemento importante e que está diretamente ligado aos motivos para a realização de um curso de pós-graduação, como fica perceptível pela resposta daqueles que indicaram que os motivos da sua participação ao curso têm a ver com a melhora nos salários.

Também não foi possível analisar se a faixa salarial indicada se refere à função de professor ou de coordenador, tendo em vista que em diversas unidades escolares, esses profissionais continuam sendo professores, mas assumem a função da coordenação e recebem uma gratificação pelo trabalho realizado, como fica evidenciado na pesquisa de Placco, Almeida e Souza (2011), o que tem certamente consequências para a carreira desses profissionais: "O aspecto da remuneração tem consequência na questão da carreira do $\mathrm{CP}$, pois, na grande maioria das escolas participantes da pesquisa, eles são contratados como professores - e não como CP”. (p.50).

Além do impacto na carreira, tem o fato de que a função exercida não é remunerada de acordo com o cargo, como ocorreu entre os coordenadores participantes do curso analisado no âmbito da UFT, tendo em vista o trecho retirado da opção "outros" do questionário, referindose à questão sobre os motivos que os levaram a realizar a pós-graduação. Um egresso pontou que mesmo desempenhando a função de coordenador pedagógico, recebia como professor.

EG 3 - O Curso foi ótimo, mas a SEDUC não garantiu até hoje nossos salários como coordenadoras, recebemos como professor diferentemente de outros Estados, mas na prática estamos utilizando muita coisa.

Dentre os motivos para realização de um curso de pós-graduação, também estão ligados às possibilidades de informações sobre o mesmo, seu processo de divulgação e as possibilidades de participação. Assim, questionamos sobre como os egressos foram informados a respeito da oferta do curso. 
Como respostas, vemos pela Tabela 4, que a menor quantidade de egressos afirmou que foi designado para realização do curso, enquanto vemos que a maioria informou que ficou sabendo do curso por meio de um colega.

Tabela 4 - Como ficou sabendo do curso?

\begin{tabular}{l|c|c}
\hline \multicolumn{1}{c}{ Informação sobre o Curso de pós-graduação } & Quant. & \% \\
\hline Fui informado (a) por um(a) colega & 44 & 53,7 \\
\hline Fui designado (a) para realizar o curso & 38 & 46,3 \\
\hline Outro & - & - \\
\hline
\end{tabular}

FONTE: SOUZA, Raquel A. Pesquisa de doutorado, 2016.

Como discutimos no Capítulo IV, os cursos de especialização do PNEGEB são ofertados em regime de colaboração entre o MEC, as universidades e os parceiros das secretarias municipais e estaduais, sendo que todos possuem funções para que essa parceria funcione.

Em relação às funções das secretarias estaduais e municipais, destacamos entre outras, aquelas relacionadas à divulgação do curso e a indicação das vagas, considerando os requisitos básicos estabelecidos pelo $\mathrm{MEC}$, entre eles que atendessem às escolas prioritárias e com baixo IDEB, os municípios que demandaram esta formação pelo PAR e os municípios que elaboraram o PAR, mas não apresentaram demanda para esta formação. (PPC/PPC, 2010).

No entanto, desses apontamentos ficam dúvidas se as vagas preenchidas atenderam a essas prioridades, tendo em vista que 38 egressos foram designados diretamente pelas secretarias e escolas do Tocantins para realizar o curso, e a maioria deles, os outros 44 egressos, informam que souberam do curso por outras vias que não seja pela divulgação ou indicação das secretarias.

Em relação ao processo de seleção dos participantes ao curso, como detalhamos no Capítulo IV, houve vários problemas para o preenchimento das vagas, tendo sido necessário o lançamento de seis editais no processo seletivo.

Sobre essa complicada questão, perguntamos ao gestor geral do curso como ocorreu o processo de formação das turmas e o preenchimento das vagas e, em resposta, ele informou que, além do processo de editais, foram feitos acordos para que as vagas fossem preenchidas, mas ressaltou que esses acordos não foram de ordem política, e sim administrativa e considerando os critérios estabelecidos pelo curso. 
Dentro dessa perspectiva o gestor destacou que:

[...] acordos foram feitos para que as vagas fossem preenchidas com os critérios do programa. Por exemplo, a Seduc fazer uma chamada própria para o curso e depois esses inscritos na chamada da Seduc, se inscreviam na chamada da universidade. No processo seletivo, o comitê interinstitucional participava e ajudava muito para que a chamada chegasse aos extremos do Estado e aos profissionais que de fato precisavam. (GESTOR, UFT/CURSO $\mathrm{CP})$.

Mesmo diante da opinião do gestor do curso, ressaltamos que não temos elementos para afirmar que os candidatos que preencheram as vagas do curso representaram de fato as demandas prioritárias de formação em atendimento às escolas que demandavam essa formação.

Ainda consideramos como item de análise sobre esse eixo relacionado ao interesse, dedicação e ingresso dos cursistas na pós-graduação, a questão sobre a localização de residência dos participantes com as cidades polo ${ }^{12}$ do curso.

Considerando a dinâmica do curso desenvolvido na modalidade a distância e o apoio presencial em cada um dos cinco polos, vemos que a maior parte deles residia na mesma cidade polo do curso ou a menos de $100 \mathrm{~km}$, conforme destacado no Gráfico 5.

Gráfico 5 - Distâncias entre as cidades polo do curso e as residências dos cursistas.

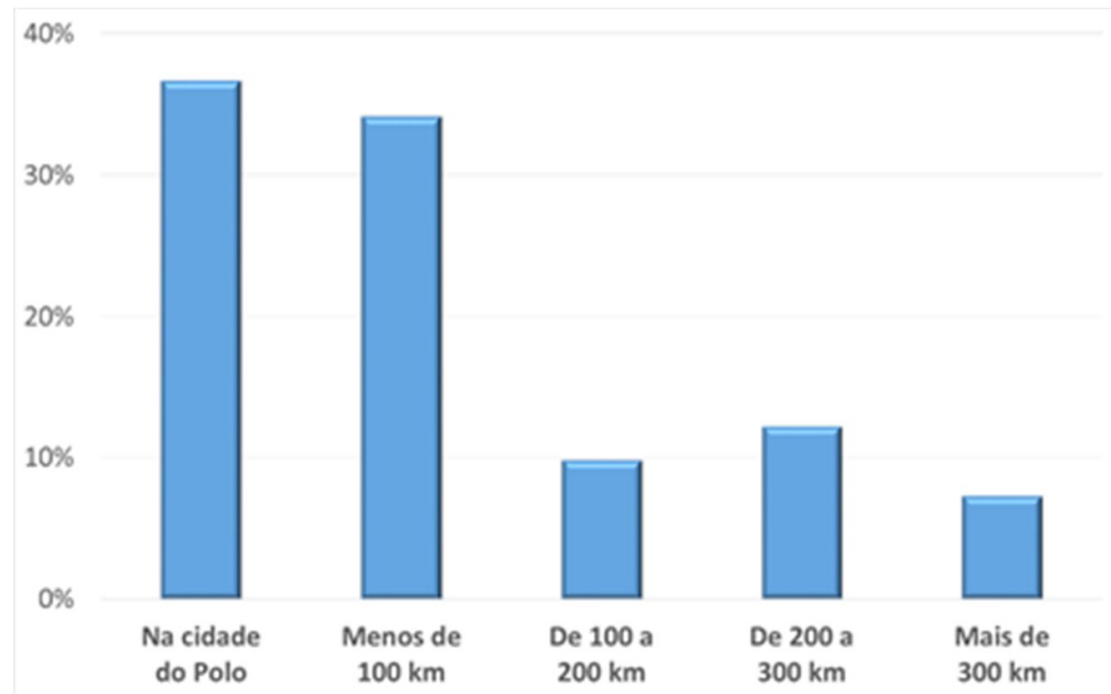

FONTE: SOUZA, Raquel A. Pesquisa de doutorado, 2016.

\footnotetext{
12 Polos: locais físicos com estrutura de computadores, acesso a internet e a presença de um professor assistente de turma. Nesses polos os cursistas podiam marcar horários com os professores para sanar dúvidas referentes ao curso e também participar dos encontros presenciais do curso.
} 
Os cursistas que residiam em cidades que distanciavam mais de $300 \mathrm{~km}$ do polo somam um quantitativo de $7 \%$, ou seja, apenas seis respondentes do questionário afirmaram morar em cidades mais distantes do polo. Os que moravam em cidades com distância entre100 a $300 \mathrm{~km}$ somam $22 \%$ e os que residiam a menos de $100 \mathrm{~km}$ representam $34 \%$.

Essas respostas dos egressos levam-nos a evidenciar certamente mais um aspecto considerado positivo, em relação aos objetivos e metas do curso, tendo em vista que os participantes não encontravam tanta dificuldade para se deslocarem e ter acesso aos polos do curso, seja para participar dos encontros presenciais ou para tirar dúvidas com relação ao conteúdo e atividades com os professores assistentes do polo.

\subsection{Perfil Esperado do Egresso a partir dos Objetivos do Curso de Pós-graduação}

O PPC da UFT apresenta os mesmos objetivos gerais e específicos do PPC encaminhado pelo MEC às universidades parceiras para a oferta do curso. Como já destacamos, de maneira geral, apresentam a pretensão de o curso contribuir com a formação do CP que atua em instituições públicas de educação básica, visando à "ampliação de suas capacidades de análise e resolução de problemas, elaboração e desenvolvimento de projetos e atividades". (UFT/PPC, 2010, p.3).

Esses objetivos estão em consonância com os objetivos básicos do documento de Diretrizes Nacionais do PNEGEB, de contribuir com a formação efetiva de gestores educacionais da escola pública, de modo que eles disponham de "elementos teórico-práticos que viabilizem uma educação escolar básica com qualidade social”, (BRASIL, DN/PNEGEB, 2009, p.6).

O PPC de referência do MEC para a oferta do curso ressalta pelo menos oito elementos esperados para o perfil do profissional após a realização do curso, dentre os quais se destaca que o egresso desse curso, seja capaz de:

- Aprofundar a compreensão da educação escolar como direito fundamental do cidadão e como instrumento de emancipação humana no contexto de uma sociedade com justiça social;

-Comprometer-se com a qualidade do trabalho pedagógico desenvolvido na escola, participando dos processos de elaboração, implementação e avaliação do Projeto Político-Pedagógico e assegurando a participação efetiva de toda a comunidade escolar;

- Incentivar o desenvolvimento de práticas educativas que promovam a melhoria do processo de ensino-aprendizagem, a articulação e a integração das ações pedagógicas; 
- Participar do fortalecimento da gestão democrática do ensino por meio da construção do trabalho coletivo e da articulação da unidade escolar com as diretrizes propagadas pelo sistema de ensino;

- Compreender a realidade escolar e a gestão dos processos educativos nas dimensões social, política, cultural, econômica e pedagógica.

- Valorizar a vivência investigativa e a busca do aperfeiçoamento profissional contínuo;

- Compreender os meios de comunicação como espaços de produção, socialização e disseminação de informações, saberes, conhecimentos e culturas e, portanto, como possibilidades de descentralização de poderes e de promoção da autonomia;

-Dominar e utilizar ferramentas tecnológicas no campo da organização dos processos de trabalho nos sistemas e unidades de ensino, tomando-as como importantes ferramentas para realização da gestão democrática da educação. (PPC/MEC, 2009).

De forma geral, nos PPCs do MEC e da UFT, há uma referência à importância do coordenador pedagógico como um membro da equipe gestora da escola potencializando suas funções e ações. O PPC do MEC é enfático ao afirmar que a proposta do curso de formação continuada para os profissionais da área da coordenação pedagógica "nasce do reconhecimento da importância desse profissional para a melhoria da qualidade do ensino brasileiro. De fato, o CP, sendo um membro da equipe gestora da escola, desenvolve o importante papel de articulador e integrador dos processos educativos.

Não temos dúvida que esse profissional é muito importante para as relações pedagógicas na escola, na sala de aula e no convívio com a comunidade escolar. No entanto, a partir das visões mais discursivas propostas pelos objetivos dos documentos oficiais, bem como por meio das vozes dos egressos, dos professores e do gestor, buscamos compreender se o curso proporcionou e como proporcionou os elementos teóricos e práticos para a formação desses profissionais, de modo que, nas suas práticas diárias, eles possam articular e integrar os saberes aos processos educativos na perspectiva da prática social.

Considerando todas as questões propostas para reflexão, ficou marcante nas respostas dos participantes o fato de quase todos concordarem que os objetivos do curso foram ou estão sendo alcançados.

Pedimos que os participantes avaliassem se a referida pós-graduação auxiliou os cursistas na ampliação de suas capacidades de análise e na resolução de problemas, bem como na elaboração e desenvolvimento de projetos e atividades no âmbito da organização do trabalho pedagógico e do processo de ensino aprendizagem.

Pelo Gráfico 6 vemos que a maioria dos egressos e dos professores concordaram que os cursistas adquiriram elementos teóricos e práticos que os auxiliam na ampliação das 
capacidades de análise e de resolução de problemas. Dos que discordaram, vemos apenas uma minoria de $2 \%$ dos egressos e os que ficaram indiferentes é representado por um percentual de $15 \%$ dos professores.

Gráfico 6 - Ampliação das capacidades de análise e resolução de problemas.

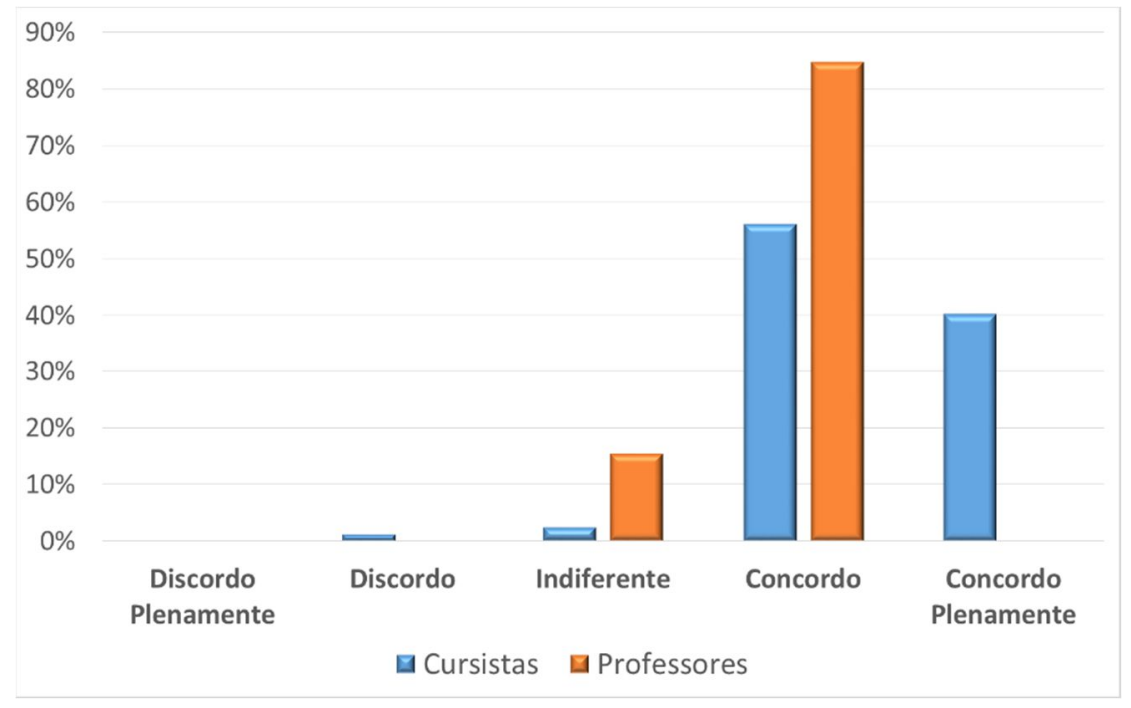

FONTE: SOUZA, Raquel A. Pesquisa de doutorado, 2016.

Questionamos se o curso possibilitou que os cursistas pudessem construir conhecimentos para melhorar a compreensão da escola como um direito fundamental do cidadão e como um instrumento de emancipação humana e como respostas, a maioria também afirmou que sim, sendo 81 egressos e 12 dos professores, havendo discordância de apenas um professor e de um egresso.

Também evidenciamos que o curso proporcionou elementos teóricos e práticos para que os cursistas pudessem participar dos debates sobre a construção coletiva do PPP de suas escolas, bem como para que eles aprendessem a articular, integrar e organizar ações pedagógicas no local em que atuavam.

Essa percepção se confirma pelas respostas da maioria de $95 \%$ dos egressos e de pelo menos $69 \%$ dos professores. O restante dos professores se mostrou indiferente e outros discordaram dessa questão. Essas percepções de concordância também se manifestaram com relação ao perfil esperado do curso no qual se prevê que os cursistas pudessem estabelecer uma relação mais direta com os meios de comunicação e domínio com as ferramentas tecnológicas.

A partir desses perfis desejados, também nos interessávamos saber se o curso proporcionou elementos para o auxílio dos cursistas sobre o manuseio das TICs, de modo que 
eles passassem a perceber essas tecnologias como meios de comunicação e espaços de produção, socialização e disseminação de informações, saberes, conhecimentos e culturas, conforme proposto pelo PPC. Como identificamos a partir das respostas organizadas na Tabela 5, a opinião do gestor, de $95 \%$ dos egressos e de $100 \%$ dos professores, foi de concordância.

Tabela 5 - Objetivos e perfil esperado.

\begin{tabular}{|c|c|c|c|c|c|c|}
\hline \multicolumn{7}{|c|}{ Objetivos e perfil esperado sobre a compreensão, utilização e domínio de TICs } \\
\hline \multirow{4}{*}{$\begin{array}{l}\text { Compreender os meios de } \\
\text { comunicação como espaços de } \\
\text { produção, socialização e } \\
\text { disseminação de informações, } \\
\text { beres, conhecimentos e culturas. }\end{array}$} & Participante & DP & D & I & $\mathbf{C}$ & $\mathbf{C P}$ \\
\hline & Egressos & $0 \%$ & $2,4 \%$ & $2,4 \%$ & $59,8 \%$ & $35,4 \%$ \\
\hline & Professores & $0 \%$ & $0 \%$ & $0 \%$ & $76,9 \%$ & $23,1 \%$ \\
\hline & Gestor & & & & $100 \%$ & \\
\hline \multirow{4}{*}{$\begin{array}{l}\text { Utilizar os meios de comunicação } \\
\text { como instrumentos de } \\
\text { descentralização de poderes e de } \\
\text { promoção de autonomia. }\end{array}$} & Part & DP & D & I & $\mathbf{C}$ & $\mathbf{C P}$ \\
\hline & Egres & $0 \%$ & $3,7 \%$ & $4,9 \%$ & $53,7 \%$ & 37,8 \\
\hline & Professo & $0 \%$ & $7,7 \%$ & $7,7 \%$ & $69,2 \%$ & 15,4 \\
\hline & Gestor & & & & $100 \%$ & \\
\hline \multirow{4}{*}{$\begin{array}{l}\text { Domínio de ferramentas tecnológicas } \\
\text { no campo da organização dos } \\
\text { processos de trabalho pedagógico } \\
\text { com vistas ao desenvolvimento de } \\
\text { uma escola mais democrática. }\end{array}$} & Participan & DP & D & $\mathbf{I}$ & $\mathbf{C}$ & $\mathbf{C P}$ \\
\hline & Egres & $0 \%$ & $1,2 \%$ & $8,5 \%$ & $51,2 \%$ & $39 \%$ \\
\hline & Professores & $0 \%$ & 23,1 & $15,4 \%$ & $53,8 \%$ & $7,7 \%$ \\
\hline & Gestor & & & & & $100 \%$ \\
\hline
\end{tabular}

FONTE: SOUZA, Raquel A. Pesquisa de doutorado, 2016.

Pela Tabela 5, também percebemos a opinião dos participantes de que o curso tenha ajudado o coordenador pedagógico a utilizar os meios de comunicação como instrumentos de descentralização de poder, tendo em vista o alcance do processo de autonomia. Nesse caso, também houve concordância da maioria dos egressos e dos professores, assim como do gestor.

Ainda sobre o perfil esperado sobre o uso das TICs na formação dos CP, buscamos compreender se o curso forneceu subsídios para que os cursistas tenham obtido o domínio de ferramentas tecnológicas no campo da organização dos processos de trabalho pedagógico de forma que elas se constituam em instrumentos que auxiliem no desenvolvimento de uma escola mais democrática.

A respeito dessa questão também evidenciamos pela Tabela 5, a concordância de quase todos os egressos e do gestor, mas na opinião dos professores, vemos um número mais reduzido daqueles que concordaram com tal afirmativa, sendo o maior quantitativo daqueles que discordaram ou se manifestaram com indiferença. 
Com relação a esses três apontamentos referentes ao perfil esperado pelos egressos, de modo que o curso tenha oportunizado elementos teóricos e práticos para que eles pudessem ter não só a compreensão, mas aprendessem utilizar e obter o domínio das Tecnologias de Informação e Comunicação, observamos, de modo geral, que houve concordância dos participantes, mais especificamente dos egressos, o que responde de forma positiva aos objetivos esperados pelo projeto do curso.

\subsubsection{Mudanças nas práticas de trabalho}

Em relação às mudanças nas práticas de trabalho dos egressos, a partir da realização do curso, fizemos apontamentos de modo que os participantes refletissem sobre elas considerando as premissas de uma prática situada no contexto da prática social.

A proposição desse eixo do questionário foi direcionada aos egressos e seus professores, sendo elaborada por meio de múltipla escolha. Solicitamos que os participantes refletissem sobre as mudanças no trabalho dos coordenadores pedagógicos das escolas públicas do Tocantins, escolhendo uma opção entre: SIM, MUITO, POUCO, NÃO COLABOROU e OUTROS.

Fizemos a afirmativa que o curso "colaborou para o fortalecimento da educação inclusiva e da gestão democrática". Dessa afirmativa, houve concordância de todos egressos e de todos os professores, embora essas posições se distingam entre os que só concordaram, os que concordaram muito ou um pouco.

Também fizemos ponderações para que os participantes avaliassem como ocorreu essa colaboração do curso. Na Tabela 6, vemos que na visão dos professores, a colaboração do curso foi bem expressiva em cada uma das opções sugeridas, inclusive em "Todas as alternativas”. Já pelo olhar dos egressos, vemos que, pelo menos, a metade deles marcou a opção "Todas as alternativas". 
Tabela 6 - Colaboração do curso

\begin{tabular}{l|c|c}
\hline \multicolumn{1}{c|}{ Ponderações } & $\begin{array}{c}\text { EG } \\
\mathbf{( \% )}\end{array}$ & $\begin{array}{c}\text { PROF. } \\
\mathbf{( \% )}\end{array}$ \\
\hline $\begin{array}{l}\text { Mesmo sendo um curso muito teórico, o cursista consegue aplicar o } \\
\text { conteúdo na prática de trabalho. }\end{array}$ & 6,4 & 15,4 \\
\hline $\begin{array}{l}\text { O conteúdo do curso se aplica à realidade do cursista no Tocantins. } \\
\text { É um curso que ensinou a manusear uma nova ferramenta/metodologia } \\
\text { de trabalho. }\end{array}$ & 6,4 & 12,8 \\
\hline $\begin{array}{l}\text { Com a ajuda do curso é possível o cursista traçar um planejamento } \\
\text { para a escola. }\end{array}$ & 20,5 & 15,4 \\
\hline Todas as alternativas. & 52,6 & 23,1 \\
\hline Outras. & 1,3 & 7,6 \\
\hline \multicolumn{2}{c}{ EG - Egressos; PROF. - Professores } \\
\hline
\end{tabular}

FONTE: SOUZA, Raquel A. Pesquisa de doutorado, 2016.

Especificamente sobre as mudanças ocorridas na prática dos CPs, fizemos questionamentos apenas para a reflexão dos egressos. Embora seja possível visualizar outra sequência de questões desse eixo de análise por meio do questionário no Apêndice I, é importante registrarmos que, para essas análises, fizemos agrupamento das questões em torno dos assuntos que se complementavam. Dessa forma, elas não seguem a mesma sequência do questionário.

Perguntamos aos egressos com que frequência eles utilizavam os conhecimentos adquiridos na especialização e mais de $90 \%$ informaram que usam sempre ou quase sempre os conhecimentos adquiridos. Isso implica considerar que essa formação continuada forneceu conhecimentos que estão sendo utilizados com uma boa frequência no trabalho dos professores/coordenadores pedagógicos e que, por essa via, o curso também alcança os objetivos esperados.

Fizemos alguns questionamentos de modo que os egressos refletissem sobre as mudanças ocorridas a partir da realização do curso. As visões desses sujeitos estão expressas na Tabela 7.

Tabela 7 - Visões sobre mudanças na formação e na prática profissional

\begin{tabular}{l|c|c|c}
\hline Variáveis & \multicolumn{3}{|c}{ Qtde $\%$} \\
\hline \multirow{3}{*}{$\begin{array}{l}\text { Consegue desenvolver, junto com a } \\
\text { equipe gestora, uma gestão mais }\end{array}$} & $\mathrm{DP}$ & 1 & 1,2 \\
\cline { 2 - 4 } democrática? & $\mathrm{D}$ & 1 & 1,2 \\
\cline { 2 - 4 } & $\mathrm{I}$ & 5 & 6,1 \\
\cline { 2 - 4 } & $\mathrm{C}$ & 27 & 38,5 \\
\cline { 2 - 4 } & $\mathrm{CP}$ & 27,9 \\
\hline
\end{tabular}




\begin{tabular}{c|c|c|c}
\hline \multirow{4}{*}{$\begin{array}{c}\text { Percebe que suas ações estão ajudando na } \\
\text { melhoria da qualidade da escola? }\end{array}$} & $\mathrm{DP}$ & 0 & $0 \%$ \\
\cline { 2 - 4 } & $\mathrm{D}$ & 0 & $0 \%$ \\
\cline { 2 - 4 } & $\mathrm{I}$ & 2 & $2,4 \%$ \\
\cline { 2 - 4 } & $\mathrm{C}$ & 50 & $61 \%$ \\
\hline \multirow{4}{*}{$\begin{array}{c}\text { Consegue propor soluções para } \\
\text { problemas práticos e pedagógicos? }\end{array}$} & $\mathrm{CP}$ & 30 & $36,6 \%$ \\
\cline { 2 - 4 } & $\mathrm{DP}$ & 0 & $0 \%$ \\
\cline { 2 - 4 } & $\mathrm{D}$ & 5 & $6,1 \%$ \\
\cline { 2 - 4 } & $\mathrm{I}$ & 46 & $56,1 \%$ \\
\cline { 2 - 4 } & $\mathrm{CP}$ & 31 & $37,8 \%$ \\
\hline
\end{tabular}

FONTE: SOUZA, Raquel A. Pesquisa de doutorado, 2016.

Questionamos se eles conseguem desenvolver uma gestão mais democrática, se suas ações ajudam na melhoria da qualidade da escola, se refletem sobre mudanças de atitudes profissionais a partir da reflexão com os conteúdos propostos pelo o curso e se percebem mudanças nos relacionamentos interpessoais. Em todas essas questões vemos que mais de $90 \%$ concordam.

A maioria dos egressos expressa que consegue junto com a equipe gestora, desenvolver uma gestão mais democrática na escola, sendo que uma pequena parte deles se mostrou indiferente ou discordou.

No mesmo sentido, vemos que 80 dos 82 egressos afirmaram que passaram a perceber que as ações que estão desenvolvendo em suas práticas profissionais, apoiadas pelos referenciais teóricos e conteúdo que foram trabalhados na formação continuada, estão ajudando a melhorar a qualidade da escola em que atuam.

Em relação à afirmativa de que o curso os ajudou a propor soluções para problemas práticos e pedagógicos à escola a partir de suas funções diárias, também identificamos a concordância da maioria, o que também aparece em registros do Relatório de Avaliação do curso, no item sobre a utilização do instrumento avaliativo "Memorial Reflexivo" (MR).

O Relatório destaca trechos de alguns cursistas que demonstraram seus sentimentos a respeito da ressignificação que passaram a fazer da própria prática pedagógica, como se percebe pelo depoimento de um cursista que demonstra a importância da pós-graduação para sua formação continuada e sinaliza que os assuntos e teorias abordadas no curso contribuíram para mudanças de posturas diante dos conflitos pedagógicos.

O curso passou a ser instrumento de mudança de paradigmas e resgate de significação profissional, bem como a incorporação de novas metodologias da prática pedagógica. As leituras do referencial teórico proporcionam reflexões sobre o fazer pedagógico, melhorando nossa visão e atitudes, enquanto sujeito de transformação. (CURSISTA 1). (UFT, RELATÓRIO AVALIAÇÃO CURSO/CP, 2012. p.34). 
O comentário de outro cursista também é destacado nesse relatório de avaliação em que é enfatizada sua postura ao refletir sobre as dificuldades encontradas, ele reconhece que o curso possibilitou melhoras na sua prática por meio de reflexões: "No início achei que seria um curso mais fácil, como outros que já fiz a distância, mas agora percebo que era este o curso que estava precisando para melhorar minha prática e fazer reflexões necessárias para ampliar o meu conhecimento". (CURSISTA 15). (UFT, RELATÓRIO AVALIAÇÃO CURSO/CP, 2012, p.34).

O depoimento de outro cursista também demonstra a importância de considerar o conhecimento prévio e relacioná-lo com os conhecimentos adquiridos na atuação profissional e diária do coordenador pedagógico:

Aprendi a importância do coordenador frente à mobilização da equipe desde
a elaboração e vivência do PPP da escola, no sentido de promover a
participação e envolvimento de todos para a organização do fazer
pedagógico e consequentemente de uma educação de qualidade. Além disso,
tivemos a oportunidade de ampliar nossa visão e conhecimento no que se
refere ao currículo escolar e oculto. Por meio das atividades propostas,
realizamos uma oficina de estudo e reflexão sobre os eixos norteadores do
currículo com base no documento "Indagações sobre o currículo" do MEC,
que muito contribuiu com o ensino aprendizagem e avaliação, visto que a
escola na qual trabalho oferta educação especial/inclusiva e trouxe à tona
discussões relevantes quanto à adaptação do currículo para atender os alunos
com necessidades especiais. Foram temáticas bastante interessantes, voltadas
para a realidade da escola atual. (CURSISTA 6). (UFT, RELATÓRIO
AVALIAÇÃO CURSO/CP, 2012, p.34).

Quando o cursista, coordenador pedagógico, reconhece que suas práticas de trabalho estão sendo ressignificadas a partir de conhecimentos que adquiriam por meio da leitura e das reflexões teóricas possibilitadas pelo processo de formação continuada, estão, de certa forma, desenvolvendo uma prática social, uma práxis que, como coloca Triviños (2006), é "uma atividade objetiva, material, fundamental, capaz de modificar a sociedade e a natureza". (p.127).

Conforme discutimos nos capítulos anteriores, consideramos que o CP pedagógico é entendido a partir de sua dimensão histórica que é determinada por múltiplas determinações ao longo de sua experiência pessoal e profissional. Dessa forma, ele é um sujeito do processo de ensino e aprendizagem e como tal, é no seu processo de formação e de trabalho que ele se transforma, transforma o meio em que atua, assim como auxilia para transformar visões e consciências dos outros indivíduos. 
Conforme argumentamos, é pelo seu trabalho, na sua dimensão ontológica que ele faz histórico na medida em que "transforma a natureza e, com isso, transforma a sua própria condição humana no mundo. Para além de sua situação de mero animal racional, realiza-se, com o trabalho, sua condição de sujeito, isto é, de condutor de ações regidas por sua vontade". (PARO, 2010, p.766).

Assim, sendo o CP um educador que busca a emancipação democrática da educação, tem seu objeto de trabalho voltado para propiciar as relações pedagógicas necessárias de convivência para contribuir com a função social do professor e da escola, que é a formação de seres humanos, humanos, ou seja, dos sujeitos históricos.

Apoiados nesses referenciais e nas respostas de concordância dos egressos, inferimos que as mudanças percebidas por eles em torno da formação proporcionada pelo curso e o reflexo de perceberem mudanças nas suas práticas diárias de trabalho, também implica considerar que os objetivos do curso foram alcançados nesse aspecto da formação.

Vemos, por suas respostas, que os egressos, ao destacarem que passaram a repensar o seu papel como coordenadores pedagógicos e a compreender melhor suas funções, acabam também, em certa medida, valorizando-se mais o que o leva reconsiderar a constituição de sua identidade profissional.

Essas inferências são ressaltadas quando questionamos os egressos se eles compreendiam ou passaram a compreender sua função como um aspecto importante da equipe gestora da escola e como respostas. Nessa questão, houve concordância de 97\%. Também perguntamos se o curso os auxiliou com elementos para que pudessem organizar o seu trabalho pedagógico e realizá-lo com mais prazer e dedicação, havendo também concordância de aproximadamente $90 \%$.

Essa compreensão sobre as mudanças de concepções e até de personalidade, certamente contribuem para a construção e afirmação da identidade do profissional da coordenação pedagógica que, como já discutimos, é construção prática e que "busca o significado do papel e exercício da cidadania e da própria humanidade". (LIMA, SANTOS, 2007, p.83).

Os respondentes também, na sua maioria, afirmaram que houve mudanças nas formas de convivência e nos relacionamentos interpessoais, quando mais de 95\% reconhecem melhoras no relacionamento desenvolvido com os professores e funcionários, assim como mais de 93\% também apontam melhoras nos relacionamentos com os alunos. 
Ainda sobre esse eixo de discussão que trata sobre as mudanças percebidas na formação e na prática, integramos a questão do questionário sobre os objetivos e metas do curso, de modo a compreendermos se os egressos concordavam que a pós-graduação também proporcionou elementos para os auxiliarem na reflexão e na prática de suas ações e nas orientações junto ao trabalho do professor. Nessa questão, houve o posicionamento de concordância de mais de $96 \%$ dos egressos.

Essas percepções indicam que esses profissionais passaram a adotar uma postura de reflexão sobre sua ação, assim como apontam que passaram a desenvolver práticas mais conscientes, associando essas mudanças às reflexões que estabeleceram a partir dos conteúdos teóricos do curso. Esse sentido de prática, de acordo com Triviños (2006, p.133), leva à compreensão de uma prática social que é a práxis do homem, ou seja, é ação prática e teórica "consciente em todos os seus momentos, especialmente no processo de produção".

Triviños (2006) lembra que a práxis no processo material, como "matéria", manifestase pela sua dimensão consciente, tendo em vista a perspectiva do materialismo dialético de considerar, entre outras questões, a condição social e histórica dos sujeitos. Nesse sentido, as vozes dos egressos demonstram o reconhecimento de que eles passaram a perceber-se como sujeitos do processo de formação e de suas práticas diárias, as quais também passaram a influenciar e causar mudanças nas práticas da escola e no trabalho dos outros sujeitos.

Então, de forma geral as análises em torno desse eixo demonstram que a maioria das respostas confirmaram as proposições de reflexões e apontam possibilidades de que houve mudanças nas práticas de trabalho dos egressos em relação ao envolvimento, o relacionamento e a mediação com o trabalho pedagógico na escola.

Por sua vez, esses profissionais, por meio de sua práxis, também são mediadores do processo pedagógico. É nesse sentido que nos referenciamos ao $\mathrm{CP}$ como sendo um sujeito que faz parte da equipe diretiva da escola e, como ressaltam Vasconcellos (2002) e Paro (2002), são profissionais que têm um caráter mediador nas relações pedagógicas e administrativas, não lhes cabendo mais um papel de controle do trabalho alheio conforme ranços da função supervisora, mas sim, que eles sejam agentes democráticos para desenvolverem ações também democráticas e, nesse sentido, o curso de formação continuada parece ter lhes proporcionado esses saberes, mesmo que a princípio, demarquem o campo mais teórico. 
Diante desse contexto, não temos dúvida que as ações dos CPs devem ser desenvolvidas na perspectiva democrática e, dessa forma, contribuir para que a escola seja um espaço de democracia, mas em sentido amplo e não no sentido proclamado pelos OIs.

Mais uma vez é importante retomar a Gramsci e perceber que o coordenador pedagógico pode e deve ser um intelectual que auxilia a categoria de professores e gestores a desenvolver o projeto educativo voltado para a emancipação dos indivíduos.

\subsection{Formação Continuada: em Foco a Metodologia de Aprender a Distância}

Nesse eixo de análise focalizamos as questões em torno da metodologia da educação a distância, utilizada para o desenvolvimento do curso em questão. Assim, retomando ao PPC da UFT, lembramos de algumas exigências feitas para que os cursistas pudessem participar, como ter disponibilidade para se dedicarem 10 horas/semanais, disponibilidade para participar dos encontros presenciais, além de ter o acesso à internet banda larga e conhecimentos básicos de informática. (PPC/UFT, 2010).

Por um lado, o documento já prescreve algumas condições referentes à racionalidade técnica, como apontado por Bonetti (2007), indicando que a participação ao curso na modalidade a distância, que apresenta entre seus discursos o de inclusão digital, já se apresenta inicialmente a seleção dos indivíduos que não teriam as habilidades e acesso às técnicas, excluindo ao invés de oportunizar a inclusão, o que é uma contradição, pois possibilidades da realização do curso por meio da EaD são reafirmadas em vários documentos oficiais.

Vemos que, no PPC da UFT, são enfatizadas as possibilidades de formação dos profissionais por meio dessa modalidade, como fica perceptível nos discursos iniciais na introdução e justificativa do documento que "A UFT acredita que, por meio das potencialidades da modalidade do ensino a distância, é possível proporcionar espaços de aprendizagens que ajudarão a romper com a 'distância' social e principalmente cultural, que é uma dura realidade no estado do Tocantins". (p.6). Então, por outro lado, as percepções dos participantes corroboram com esses apontamentos dos documentos oficiais.

Solicitamos aos participantes que refletissem sobre a seguinte afirmação: “o Ambiente Virtual de Aprendizagem, o AVA moodle, foi um excelente ambiente e não apresentou problemas técnicos durante o desenvolvimento do curso". Dessa afirmativa, como podemos observar pela Tabela 8 , houve concordância de quase $90 \%$ dos egressos. 
Tabela 8 - Ambiente Virtual de Aprendizagem

Objetivos e perfil esperado sobre a compreensão, utilização e domínio de TICs

O AVA (Ambiente Virtual de Aprendizagem/MOODLE) é um

excelente ambiente e não

apresentou problemas técnicos

durante todo o curso.

\begin{tabular}{|c|c|c|c|c|c} 
Participantes & DP & D & I & C & CP \\
\hline Egressos & $2,4 \%$ & $6,1 \%$ & $2,4 \%$ & $62,2 \%$ & $26,8 \%$ \\
\hline Professores & $0 \%$ & $38,5 \%$ & $0 \%$ & $38,5 \%$ & $23,1 \%$ \\
\hline Gestor & & $100 \%$ & & & \\
\hline
\end{tabular}

FONTE: SOUZA, Raquel A. Pesquisa de doutorado, 2016.

Das reflexões dos professores, não percebemos um quantitativo tão expressivo de concordância como dos egressos, pois vemos que aproximadamente $62 \%$ concordaram. $\mathrm{O}$ restante dos professores $(38,5 \%)$ discordaram dessa colocação, o que indica que o ambiente não foi tão excelente e que, ao longo do curso, problemas técnicos ocorreram e certamente influenciaram no desenvolvimento do curso, o que também se soma à análise feita anteriormente sobre a racionalidade técnica.

Essa visão de discordância corrobora a percepção do gestor geral do curso, o qual ressaltou em resposta aberta do questionário, que embora reconheça que o AVA moodle seja um bom ambiente, ele se trata de uma tecnologia e ela por si mesma não é capaz de fazer “mágica se não tiver a manutenção e uso necessário". (GESTOR CURSO/CP/UFT).

Sobre os problemas de ordem técnica e de acesso ao ambiente, questionamos os participantes da pesquisa se os cursistas tiveram problemas de navegação e de acesso ao AVA. A opinião de quase $90 \%$ dos egressos e a opinião do gestor foi que os cursistas não tiveram problemas, mas a opinião da maioria dos professores foi de discordância.

Considerando os pré-requisitos para participação ao curso, conforme estabelecidos pelo PPC, afirmamos que "os cursistas não tiveram problemas, pois tinham acesso à internet, possuíam computadores, e tinham facilidades para manusear tecnologias". Sobre essa afirmativa também houve concordância da maioria de $85 \%$ dos egressos.

Aparentemente por meio dessas vozes, seria possível inferir que o saber técnico prévio, a racionalidade técnica, como aponta Bonneti (2007), parece ter sido um fator que contribuiu para que os cursistas realizassem e se mantivessem no curso. No entanto, não evidenciamos o que essa racionalidade exigiu deles, além disso, é uma percepção que não esteve em conformidade com a opinião dos outros $15 \%$ dos egressos que discordaram ou ficaram indiferentes, nem mesmo da opinião do gestor e da maioria de $77 \%$ dos professores que também não concordaram. 
Essa percepção de discordância de alguns egressos, dos professores e do gestor é corroborada no Relatório de Avaliação do Curso, o qual apresenta no item sobre o Memorial Reflexivo, a síntese das dificuldades encontradas pelos egressos, em que se destaca que "Alguns cursistas mencionaram a dificuldade em relação à falta de acesso ao computador e à internet". (p.32). O Relatório também aponta que essa postura reflete um problema contraditório, pois para se inscrever no curso, o participante deveria declarar que tinha acesso aos recursos tecnológicos e facilidade de manuseio, os quais eram pré-requisitos para realização do curso.

Os professores dessa turma, ao analisarem essas questões, registraram na síntese geral do MR que o acesso ao ambiente virtual de aprendizagem torna-se difícil quando os sujeitos não têm acesso e não têm aproximação com alguns recursos que o ambiente de aprendizagem proporciona, o que dificulta a otimização do tempo e a resolução das situações-problemas que são sugeridas pelas atividades de cada sala ambiente. (UFT, RELATÓRIO DE AVALIAÇÃO DO CURSO, 2012, p.32).

Como discutimos no Capítulo II, há um consenso proclamado pelos OIs e pelas políticas de formação de profissionais da educação de que a EaD é uma potencialidade para aprendizagem e para a inclusão digital, e para que isso não se restrinja apenas à POD, esperase que os cursos a distância de fato possibilitem aos sujeitos as oportunidades de formação mais ampla, sobretudo que ocorra a inclusão digital, mesmo que os participantes que não tenham os aparatos e ferramentas tecnológicas, não sejam responsabilizados pela falta do acesso ou por que não dominam o manuseio tecnológico.

Interessante retomar as análises sobre o perfil esperado dos egressos em relação à utilização das TICs, em que os egressos afirmaram que o curso proporcionou elementos teóricos e práticos para que eles pudessem utilizar e ter o domínio dessas tecnologias.

Essas visões apresentam um posicionamento que vai ao encontro dos argumentos utilizados nos documentos oficiais, no entanto entram em contradição com os apontamentos de discordância aqui demonstrados, embora ainda seja o mesmo pensamento dos egressos.

Continuamos a fazer assertivas aos participantes para compreender suas visões sobre a modalidade da pós-graduação visando entender se eles concordavam que ela foi uma estratégia acertada para o curso e, nessa questão, quase todos os respondentes também mostraram concordância.

Sobre a afirmativa: "A metodologia da EaD permitiu e proporcionou ao cursista desenvolver o potencial crítico e reflexivo por meio da participação nos debates e na produção 
das atividades individuais e em grupo", houve concordância do gestor, de 95\% dos egressos e de $85 \%$ dos professores.

Esses posicionamentos de concordância reafirmam os discursos apresentados nos documentos institucionais, de que essa metodologia auxilia a formação de profissionais, sobretudo daqueles que, por diversos motivos, não teriam condições de realizar um curso presencial. O PPC da UFT é enfático ao argumentar que só por meio da $\mathrm{EaD}$ seria possível esse tipo de formação "considerando a realidade do estado do Tocantins". (p.4).

No PPC do MEC, essa visão também é evidente, como podemos perceber no trecho:

Considerando o elevado número de profissionais que exercem a função de Coordenadores Pedagógicos nas instituições públicas de educação básica, bem como as dificuldades que muitos deles encontram na efetivação de sua formação continuada e pós-graduada, a proposta será desenvolvida na modalidade do ensino a distância $(\mathrm{EaD})$. $\mathrm{O}$ ensino a distância, mediado pelas diferentes tecnologias de informação e comunicação, vem sendo utilizado como alternativa para ampliar a oferta de cursos de formação continuada e pós-graduada, em especial nas regiões onde a oferta de alternativas de formação se apresenta ainda insuficiente. (BRASIL, MEC/PPC, 2009, p.4). (grifo nosso).

Essa questão corrobora também a visão do gestor que se manifesta na opção "Outros" de escrita livre, que a EaD foi uma estratégia acertada para a oferta dessa pós-graduação. Registra que, se assim não fosse, muitos alunos não fariam uma especialização lato sensu, "centenas desses alunos não teriam outra oportunidade se não fosse por meio dessa estratégia”. (GESTOR CURSO/CP/UFT).

Vemos mais uma vez que esses olhares dos participantes confirmam os ideais apresentados pelos documentos oficiais de criação do curso, sobre as possibilidades de a pósgraduação ocorrer por meio da mediação das tecnologias da informação e comunicação a partir da via da educação a distância.

Essas visões podem de fato refletir as possibilidades dessa modalidade de educação. No entanto, não podemos ignorar que o PNEGEB e o curso analisado foram criados e implantados no contexto neoliberal em que a EaD é colocada como uma possibilidade de formação, portanto é instituída como um programa pensado, elaborado para ser realizado em diferentes regiões do país, como se todos os indivíduos em formação fossem iguais. 


\subsubsection{Atuação e Acompanhamento dos Professores}

Considerando que, na dinâmica de cursos desenvolvidos na modalidade da educação a distância, a atuação dos professores é importante para o processo de ensino e aprendizagem, não porque os documentos assim sinalizam, mas porque é um fator determinante para o processo educacional, seja ele presencial ou a distância. Assim, buscamos compreender as visões dos participantes sobre o papel dos professores apresentando afirmativas sobre a suficiência da atuação e do acompanhamento deles.

Os professores que atuaram nesse curso de pós-graduação foram 15 e os dados aqui se referem às respostas dos 13 respondentes do questionário. Todos são profissionais da educação com formação em curso de Pedagogia, sendo que oito deles eram professores da UFT, três eram professores de escolas estaduais e dois eram funcionários técnicos da SEDUC-TO.

Oito professores tinham mestrado e um possuía doutorado. Outros três possuíam especialização lato sensu e um professor não possuía nenhuma pós-graduação. Nove professores possuíam pós-graduação na área específica das políticas educacionais ou da gestão escolar.

Sobre a experiência desses professores com outros cursos de educação a distância, evidenciamos que cinco deles já haviam atuado como professor em outro curso, quatro tiveram experiência como tutor e três apenas como aluno de cursos nessa modalidade. Um professor declarou que não tinha nenhuma experiência com cursos a distância.

Ao serem questionados sobre como se tornaram professores da pós-graduação no curso de especialização em Coordenação Pedagógica, a maioria (11 docentes) destacou que foram convidados pela coordenação geral do curso e os outros dois professores informaram que foram indicados pela secretaria municipal e estadual de educação do Tocantins.

Questionamos sobre qual era a carga horária de trabalho semanal dos professores, considerando as horas dedicadas no trabalho diário e as horas dedicadas ao curso. Conforme evidenciamos nas repostas, quatro professores afirmaram trabalhar uma carga horária semanal acima de 50 horas, outros quatro afirmaram trabalhar entre 40 e 50 horas e, ainda, outros quatro pontuaram que tinham carga horária em torno de 20 a 30 horas, sendo que apenas um professor informou que trabalhava menos de 20 horas.

Solicitamos que os professores refletissem sobre a carga horária de trabalho e a dedicação ao curso. Dois professores consideram que tinham uma carga horária semanal 
tranquila e, portanto, afirmou que era possível realizar um bom trabalho tanto na função profissional do dia a dia, como na função do curso.

Sete professores consideraram que a carga horária era tranquila e flexível, tendo em vista a modalidade ser a distância e, por isso, conseguiam realizar um bom trabalho em suas funções diárias e se dedicar ao curso. Os outros quatro professores sinalizaram que a carga horária não foi tranquila e, por isso, tiveram que se desdobrar muito para realizar bem ambas as funções.

A partir dessa visão mais específica sobre o perfil dos professores que atuaram na pósgraduação, fizemos três afirmativas de que a atuação deles no curso tenha sido suficiente: "para os debates dos conteúdos, instigando a participação dos cursistas", suficiente para "as orientações das atividades" e também "para o desenvolvimento do TCC", conforme evidenciamos pela Tabela 9.

De forma geral, vemos que a maioria dos egressos e dos professores, além do gestor, concordaram com as três afirmativas, considerando que a participação e a orientação dos docentes foram suficientes para o desenvolvimento da aprendizagem e desempenho dos cursistas.

Tabela 9 - Atuação e acompanhamento dos professores.

\begin{tabular}{|c|c|c|c|c|c|c|}
\hline \multicolumn{7}{|c|}{ Percencões sobre a particinacão dos nrofessores no curso } \\
\hline & Participantes & DP & D & I & $\mathbf{C}$ & $\mathbf{C P}$ \\
\hline \multirow{3}{*}{$\begin{array}{l}\text { A atuação e acompanhamento dos } \\
\text { professores foram suficientes para os } \\
\text { debates dos conteúdos, instigando a } \\
\text { participação dos cursistas, }\end{array}$} & Egressos & $1,2 \%$ & $3,7 \%$ & $2,4 \%$ & $57,3 \%$ & $35,4 \%$ \\
\hline & Professores & $0 \%$ & $0 \%$ & $7,7 \%$ & $84,6 \%$ & $7,7 \%$ \\
\hline & Gestor & - & - & - & $100 \%$ & - \\
\hline \multirow{3}{*}{$\begin{array}{l}\text { A atuação e acompanhamento dos } \\
\text { professores foram suficientes para as } \\
\text { orientações das atividades. }\end{array}$} & Egressos & $2,4 \%$ & $1,2 \%$ & $3,7 \%$ & $59,8 \%$ & $32,9 \%$ \\
\hline & Professores & $0 \%$ & $7,7 \%$ & $0 \%$ & $92,3 \%$ & $0 \%$ \\
\hline & Gestor & - & - & - & $100 \%$ & - \\
\hline \multirow{3}{*}{$\begin{array}{c}\text { A orientação e acompanhamento dos } \\
\text { professores foram suficientes para o } \\
\text { desenvolvimento dos TCCs }\end{array}$} & Egressos & $1,2 \%$ & $4,9 \%$ & $1,2 \%$ & $47,6 \%$ & $45,1 \%$ \\
\hline & Professores & $7,7 \%$ & $7,7 \%$ & $0 \%$ & $69,2 \%$ & $15,4 \%$ \\
\hline & Gestor & - & - & - & $100 \%$ & - \\
\hline
\end{tabular}

FONTE: SOUZA, Raquel A. Pesquisa de doutorado, 2016.

Percebemos, porém, de forma mais específica em relação às afirmativas, algumas discordâncias, por exemplo, a opinião de quase $8 \%$ dos egressos que não concordaram ou ficaram indiferentes sobre a afirmativa de que a atuação dos professores referente à instigação e participação dos debates sobre os conteúdos, tenha sido tão suficiente. 
Os próprios professores ao analisarem essa afirmativa também mostram dúvidas sobre essa suficiência, quando pelo menos 7,7\% se mostram indiferentes. O mesmo percentual de professores também se coloca em desacordo com relação à afirmativa de que sua atuação tenha sido excelente quando afirmamos que eles acompanharam e orientaram os alunos durante a realização das atividades, o que também fica registrado pela opinião de $3,6 \%$ dos egressos.

Sobre o acompanhamento e orientação dos professores aos cursistas para que esses desenvolvessem os TCCs, também aparece o registro de discordância de pelos menos $6 \%$ dos egressos, sendo ainda mais evidenciado pelos próprios docentes, quando 15,4\% deles não concordam que a orientação a essa atividade tenha sido tão suficiente, o que demonstra o reconhecimento de que poderia ter sido melhor o processo a atuação dos professores, como visualizado pela Tabela 9 .

De forma geral, mesmo percebendo discordâncias e indiferenças sobre a suficiência da atuação e acompanhamento dos professores ao desenvolvimento da aprendizagem dos cursistas, o que fica evidenciado pelas vozes da maioria dos participantes da pesquisa é que elas confirmam que, nesse quesito, o curso também tenha alcançado seus objetivos, o que é também corroborado pelos apontamentos dos documentos oficiais.

Um exemplo é o registro feito no Relatório de Avaliação do Curso sobre o argumento de cursistas que consideraram relevante e importante a orientação dos professores em relação à elaboração do projeto de intervenção, destacando que o "acompanhamento permitiu que o grupo avançasse no processo de aprendizagem para a elaboração dos projetos”. (p.30).

Nessa perspectiva, o Relatório destaca o seguinte depoimento de um cursista:

Os textos estudados, discutidos e orientados pelos professores, trouxeram muitos subsídios para lidar com as ações do cotidiano e auxiliaram tanto no Projeto de Pesquisa, pois ele está relacionado com o Tema da Sala 4, "Projeto Político-Pedagógico e a organização do ensino. Muitos textos dessa sala foram utilizados no planejamento e dia pedagógico e surtiram um grande efeito no grupo de professores, que passaram a fazer uma reflexão maior sobre o papel do PPP na escola. A sala de currículos também tem auxiliado muito, os textos são muito bons e no dia da Escolha do Livro Didático fiz uma reflexão quanto ao referencial curricular e quanto ao livro didático como "suporte curricular" no ensino. (UFT, RELATÓRIO DE AVALIAÇÃO DE CURSO, 2012) (CURSISTA 6. p.31).

Não temos elementos qualitativos para analisarmos essas visões de discordância dos participantes, mas elas se expressam como vemos pela posição daqueles professores os quais 
consideram que, durante sua atuação no curso, tiveram uma carga horária excessiva de trabalho, o que certamente pode ter impedido de se dedicarem mais e melhor ao curso.

Outra inferência possível relaciona-se ao fato de que apenas cinco professores afirmaram possuir experiência como docente em cursos na modalidade da educação a distância, sendo que os outros foram tutores ou alunos. Associado a essa questão, infere-se também que, como uma grande maioria não possuía pós-graduação na área de políticas da educação ou gestão escolar, podem ter sentido dificuldades de ordem teórica para orientar os cursistas, principalmente em relação ao desenvolvimento dos TCCs.

\subsubsection{Percepções sobre as Parcerias}

No Capítulo IV, destacamos que a oferta dos cursos de especialização a partir do PNEGEB ocorre por meio de parcerias entre universidades, secretarias estaduais e municipais e o MEC. No caso do Tocantins, o PPC do curso aponta como parceiros estratégicos o MEC/SEB como o proponente e financiador do Projeto, a União dos Dirigentes Municipais de Educação (Undime/TO), a Secretaria de Educação do estado do Tocantins (SEDUC/TO) e a UFT por meio da Diretoria de Tecnologias Educacionais (DTE).

Tendo em vista os apontamentos apresentados sobre as funções estabelecidas entre os parceiros para a oferta do curso e considerando as discussões sobre o regime de colaboração e parcerias, como destacamos pela visão de Saviani $(2009$, 2011), passamos a compreender nesse eixo como os participantes compreendem as parcerias estabelecidas no âmbito do desenvolvimento do curso no Tocantins.

Tabela 10 - Parcerias UFT, MEC para desenvolvimento do curso de especialização.

\begin{tabular}{|c|c|c|c|c|c|c|}
\hline & Participantes & DP & D & $\mathbf{I}$ & $\mathrm{C}$ & $\mathbf{C P}$ \\
\hline \multirow{3}{*}{$\begin{array}{c}\text { A UFT viabilizou as condições } \\
\text { necessárias para o desenvolvimento } \\
\text { do curso }\end{array}$} & Egressos & $0 \%$ & $2,4 \%$ & $1,2 \%$ & $61 \%$ & $35,4 \%$ \\
\hline & Professores & $0 \%$ & $7,7 \%$ & $0 \%$ & $84,6 \%$ & $7,7 \%$ \\
\hline & Gestor & - & - & - & $100 \%$ & - \\
\hline \multirow{3}{*}{$\begin{array}{l}\text { O MEC formulou uma política de } \\
\text { formação de professores/gestores, } \\
\text { adequada à realidade do estado do } \\
\text { Tocantins }\end{array}$} & Egressos & $1,2 \%$ & $3,7 \%$ & $7,3 \%$ & $59,8 \%$ & $28 \%$ \\
\hline & Professores & $0 \%$ & $7,7 \%$ & $46,2 \%$ & $38,4 \%$ & $7,7 \%$ \\
\hline & Gestor & - & - & $100 \%$ & - & - \\
\hline
\end{tabular}

DP - Discordo Plenamente; D - Discordo; I - Indiferente; C- Concordo; CP - Concordo Plenamente.

FONTE: SOUZA, Raquel A. Pesquisa de doutorado, 2016. 
Como podemos observar pelos dados compilados na Tabela 10, quando questionamos os participantes se a UFT viabilizou as condições necessárias para o desenvolvimento do curso, a maioria das opiniões foi de concordância.

O gestor marcou a opção de concordância, mas justificou sua resposta afirmando que a gestão de projetos de cursos financiados pelo MEC depende muito da administração local do curso, o qual tem que se organizar para utilizar os recursos financeiros que nem sempre são suficientes para uma pós-graduação lato sensu. Por isso, em sua opinião registrada na opção de resposta livre, ele destaca: "Sim e não! A gestão de projetos como esse depende muito da gestão do curso. As condições estão relacionadas aos recursos que foram disponibilizados para o curso, como sempre os recursos são insuficientes, logo as condições também não serão as ideais". (GESTOR CURSO/CP/UFT).

Sobre a parceria do Ministério de Educação, procuramos compreender se o PNEGEB se constituiu como uma das ações da política de formação de professores/gestores de maneira adequada à realidade do estado do Tocantins. A opinião da maioria dos egressos foi de concordância. No entanto, como observamos na Tabela 10, a maioria dos professores discordou e o gestor, por sua vez, ficou indiferente a essa questão.

Sobre as parcerias das secretarias municipais e estaduais, considerando que o PPC da UFT sinaliza que elas deveriam auxiliar os cursistas, entre outras coisas, no aspecto financeiro para os deslocamentos deles aos encontros presenciais, bem como, dar suporte durante o desenvolvimento dos projetos de intervenção nas escolas dentre outras funções da parceria.

Pela Tabela 11 vemos que os participantes consideram que houve viabilização da secretaria municipal e estadual em relação às ações para auxiliar a participação dos professores/coordenadores ao curso, como vemos pela concordância de mais da metade dos egressos. Mas na opinião dos professores houve pouca concordância, assim como houve expressão de indiferença do gestor.

Tabela 11 - Parcerias Secretarias.

\begin{tabular}{|c|c|c|c|c|c|c|}
\hline \multicolumn{7}{|c|}{ Parcerias para oferta do curso de especialização em coordenação pedagógica } \\
\hline & Participantes & DP & $\mathbf{D}$ & I & $\mathbf{C}$ & $\mathbf{C P}$ \\
\hline \multirow{3}{*}{$\begin{array}{c}\text { A Secretaria Municipal ou } \\
\text { Estadual de Educação viabilizou } \\
\text { ações para auxiliar a participação } \\
\text { dos cursistas para a realização } \\
\text { das atividades no curso? }\end{array}$} & Egress & $3,7 \%$ & $14,6 \%$ & $7,3 \%$ & $51,2 \%$ & $23,2 \%$ \\
\hline & Professores & $7,7 \%$ & $53,8 \%$ & $0 \%$ & $30,8 \%$ & $7,7 \%$ \\
\hline & Gestor & - & - & - & $100 \%$ & - \\
\hline
\end{tabular}




\begin{tabular}{|c|c|c|c|c|c|c|}
\hline \multirow{3}{*}{$\begin{array}{l}\text { A Secretaria Municipal ou } \\
\text { Estadual de Educação viabilizou } \\
\text { a participação dos cursistas } \\
\text { auxiliando-os financeiramente } \\
\text { para participar dos encontros } \\
\text { presenciais? }\end{array}$} & Egressos & $24,4 \%$ & $15,8 \%$ & $14,6 \%$ & $22 \%$ & $23,2 \%$ \\
\hline & Professores & $7,7 \%$ & $30,7 \%$ & $38,5 \%$ & $23,1 \%$ & $0 \%$ \\
\hline & Gestor & - & $100 \%$ & - & - & - \\
\hline \multirow{3}{*}{$\begin{array}{l}\text { A Secretaria Municipal ou } \\
\text { Estadual de Educação viabilizou } \\
\text { a participação dos cursistas } \\
\text { respeitando a atuação deles } \\
\text { como coordenadores } \\
\text { pedagógicos, bem como } \\
\text { apoiando as ações dos projetos } \\
\text { de intervenções? }\end{array}$} & Egressos & $7,3 \%$ & $6,1 \%$ & $12,2 \%$ & $50 \%$ & $24,4 \%$ \\
\hline & Professores & $0 \%$ & $23,1 \%$ & $23,1 \%$ & $46,1 \%$ & $7,7 \%$ \\
\hline & Gestor & - & - & $100 \%$ & - & - \\
\hline
\end{tabular}

FONTE: SOUZA, Raquel A. Pesquisa de doutorado, 2016.

A esse respeito, o gestor se manifestou na opção "Outros" do questionário que essa questão não tinha como ser acompanhada pela gestão do curso no âmbito da UFT, tendo em vista que fazia parte das funções dos parceiros, embora ele reconhecesse que se trata de um fator que pode ter afetado muitos cursistas.

Também é difícil de responder porque cada prefeitura deveria ter a sua contribuição e os representantes da Undime-TO estavam bem atentos a isso mas não tinham como determinar que o apoio fosse efetivo. Quanto ao Estado também, os representantes da Seduc estavam bastante atentos, mas a gestão da escola podia não ter a mesma boa vontade até por questões de política interna da unidade escolar. (GESTOR CURSO/CP/UFT).

Também questionamos os participantes sobre o auxílio financeiro das secretarias estaduais e municipais para viabilizar a participação dos cursistas nos encontros presenciais, conforme previsto pelo PPC do MEC. O gestor do curso discordou que houve auxílio financeiro, mas ressaltou que essa foi uma ação pontual em alguns municípios.

Na Tabela 11, sobre esse questionamento, vemos que houve discordância também da maioria dos professores e de pelo menos $55 \%$ dos egressos. Entre aqueles que concordaram que as secretarias auxiliaram os cursistas com recursos financeiros, observamos um menor quantitativo de opiniões, sendo menos da metade (45\%) dos egressos e apenas $23 \%$ dos professores que pontuaram que houve algum tipo de ajuda financeira.

Também questionamos se eles perceberam que as secretarias municipais e estaduais, respeitaram a atuação dos cursistas como coordenadores pedagógicos e/ou pelas funções afins 
pelas quais ingressaram no curso, bem como se esses parceiros apoiaram as ações de desenvolvimento dos projetos de intervenção.

Sobre essa questão, vemos também pelos dados da Tabela 11que houve concordância de mais da metade dos egressos e da metade dos professores. As opiniões de discordância e de indiferença entre os professores somaram $46 \%$ e entre os egressos somaram $25 \%$.

Nessa questão, o gestor do curso discordou sinalizando em resposta livre que essa era uma orientação geral em que os parceiros também tinham dentre suas ações, mas que ela dependia da gestão local das escolas.

Ao que percebemos, os parceiros municipais e estaduais não cumpriram com os acordos estabelecidos nas parcerias do curso. O Relatório Final do Curso (2012) registra dentre as reclamações dos cursistas, situações que dificultaram o desenvolvimento como: “A falta de apoio financeiro, principalmente aos cursistas vinculados a Semed's e quanto aos cursistas ligados a Seduc-TO, a orientação era para que os gestores escolares utilizassem os recursos da escola para esse fim. Embora fossem pouquíssimos os casos relatados que esse apoio se efetivou" (p.13).

Sabemos que o regime de colaboração, a partir da compreensão estabelecida pela Constituição Federal de 1988 e pela LDB, nº394/96, prevê que os municípios atuarão necessariamente na educação infantil e no ensino fundamental, como estabelece o artigo 11 da referida Lei, no inciso $\mathrm{V}$, que os municípios podem:

[...] oferecer a educação infantil em creches e pré-escolas, e, com prioridade, o ensino fundamental, permitida a atuação em outros níveis de ensino somente quando estiverem atendidas plenamente as necessidades de sua área de competência e com recursos acima dos percentuais mínimos vinculados pela Constituição Federal para manutenção e desenvolvimento do ensino. (LDB, nº964/96, Art. 11, V).

Esse preceito legal pode ser uma resposta dos gestores municipais ao não cumprimento de um de seus papéis na parceria, na função de financiar as passagens, diárias, enfim, de auxiliar financeiramente os deslocamentos dos cursistas aos encontros presenciais ou mesmo aos polos do curso para que eles tirassem dúvidas ou pudessem se encontrar com os professores assistentes de polos. A própria LDB dá o respaldo aos municípios quando reafirma que ele não tem o compromisso com a formação dos profissionais da educação, o que fica exclusivo como matéria da União e dos Estados. 
No entanto, mesmo que não seja de sua incumbência, concordamos assim como coloca Saviani (2012) que esse ente federativo tem um papel fundamental nas discussões e proposições dos cursos de formação.

Fica claro, pois, que a repartição das atribuições não implica a exclusão da participação dos entes aos quais não cabe a responsabilidade direta pelo cumprimento daquela função. Eles participarão por meio dos respectivos colegiados acompanhando e apresentando subsídios que venham a tornar mais qualificadas as decisões tomadas. E assumirão responsabilidades diretas nos aspectos que lhes correspondem por meio das Secretarias e Conselhos Estaduais de Educação e das Secretarias e Conselhos Municipais de Educação sempre que tal procedimento venha a concorrer para a flexibilização e maior eficácia da operação do sistema sem prejuízo, evidentemente, do comum padrão de qualidade que caracteriza o Sistema Nacional de Educação. (p.3).

Dessa forma, se os municípios não possuem os recursos necessários para apoiar cursos de formação de gestores, poderiam articular-se de alguma maneira como instâncias gestoras locais com os estados e a com a própria União, a fim de que alternativas pudessem ser encontradas de forma a auxiliar a dinâmica do curso.

\subsection{Síntese do Capítulo}

O processo de definição de uma política pública reflete o conflito de interesses de grupos que perpassam o Estado e a sociedade, como pontua Höfling (2001). No caso das políticas de educação que são também políticas sociais, elas se referem "a ações que determinam o padrão de proteção social implementado pelo Estado, e que estão voltadas, em princípio, para a redistribuição dos benefícios sociais visando à diminuição das desigualdades estruturais produzidas pelo desenvolvimento socioeconômico". (p.31).

Assim, o PNEGEB como uma política pública de educação é uma política social que tem origem nos anseios de profissionais da educação que precisam de formação adequada para sua profissão e ao mesmo tempo, apresenta-se como uma ação implantada pelo Estado, a partir de projetos de governos.

Nesse sentido, vimos como é importante entender a política de formação de professores/gestores a partir da totalidade das suas múltiplas determinações, pois a experiência analisada é uma totalidade constituinte de totalidades representada pelo PNEGEB e o curso lato sensu para CP, que por sua vez, apresenta-se como uma ação que compõe as políticas de formação de profissionais da educação as quais são estabelecidas num contexto 
em que os OIs impõem suas diretrizes e seus consensos para a formação desses profissionais.

Da experiência analisada e do referencial teórico que auxilia a discussão, fica perceptível que o movimento reformista da educação brasileira por meio da intensificação da presença e orientações desses OIs, nas políticas de formação, tem exigido que as práticas de formação de professores/gestores acompanhem o processo de modernização pelo qual a economia mundial passa e, nesse sentido, também é necessário profissionalizar a gestão escolar, a qual tem como importantes atores os coordenadores pedagógicos (CP).

No entanto, na perspectiva gramsciana, a política não é monolítica, expressa contradições, como percebemos no movimento analisado, tanto em relação às visões dos atores da pesquisa, quanto somadas às contradições apresentadas pelas pesquisas em âmbito nacional, conforme mapeamento realizado no Banco de Dados da Capes e apresentado no Capítulo IV.

Em vista desses apontamentos, questionamos se a formação desenvolvida por meio do PNEGEB esteve no eixo das diretrizes dos OIs ou apresentou outra perspectiva a essas diretrizes. As análises mostraram perspectivas contrárias às diretrizes dos OIs como evidenciado pelas visões dos sujeitos da pesquisa, bem como da análise dos documentos.

Como analisamos uma experiência pontual de formação no âmbito do PNEGEB, não podemos afirmar que essas percepções representam as visões de outros participantes em outras experiências ao longo do Brasil. No entanto, podemos compreender que as vozes expressam que o curso de pós-graduação lato sensu apresenta-se como uma possibilidade de resposta contrária aos ideais das políticas de formação cuja tônica atual é pelas vias da formação para o mercado.

Por outro lado, não é possível afirmar que essas contradições viabilizam a perspectiva da contra-hegemonia ou da crise hegemônica como postulado por Gramsci, em que os indivíduos se mostram profundamente politizados, conseguem construir uma consciência de "classe", criam consensos hegemônicos de superação aos anseios da "classe" dominante, ou que conseguem transformar-se e transformar o meio em que atuam.

Podemos inferir, contudo, que a formação continuada dos profissionais de coordenação pedagógica no Tocantins forneceu-lhes elementos teóricos e práticos que, nas vozes dos participantes dessa formação, estão auxiliando e contribuindo com o fortalecimento das práticas de gestão democrática na escola, assim como também expressaram mudanças nas suas práticas diárias de trabalho. 


\section{CONCLUSÕES}

O estudo realizado a partir desta tese não teve a intenção de analisar ou avaliar a política de formação para gestores escolares no Brasil, expressa pelo PNEGEB, mas teve como objetivo geral a intenção de compreender as determinações dessa política a partir da experiência do curso de especialização lato sensu em Coordenação Pedagógica ofertado pela UFT e seus parceiros no ano de 2010-2011 na voz dos seus egressos.

Ao situarmos o objeto de estudo, o curso de especialização para $\mathrm{CP}$, no contexto mais amplo das políticas de formação para professores/gestores na atual sociedade capitalista, foi possível perceber contradições, uma vez que seus resultados expressam uma política bem sucedida no Tocantins, ao passo que foi formulada e desenvolvida no contexto em que as demandas por formação seguem princípios ditados por Organismos Internacionais.

As análises dos documentos oficiais de criação do referido curso de especialização no âmbito do MEC e da UFT mostram que há uma intenção de que essa política seja uma proposta de formação para profisssionais da educação que integre o percurso formativo teórico com as práticas do cotidiano desses profissionais. Além disso, advogam uma formação baseada na gestão democrática e inclusão social da educação.

Por sua vez, esses preceitos discursivos dos documentos apontam para a distinção que chamamos de Políticas Oficialmente Declaradas - POD, pois, embora não fique expresso nos textos, é preciso considerar que há, no contexto macro de sua formulação e execução, influências do Banco Mundial para a educação básica, à gestão e à avaliação.

A gestão é entendida como o discurso da racionalização financeira em termos de eficiência e eficácia na alocação de recursos e tendo, como parâmetro de avaliação, testes padronizados em larga escala com critérios de mercado e o apelo à parceria com o setor privado. Isso indica que o lugar reservado à educação no Brasil, dentro dos planos políticos e econômicos do Banco Mundial, deve ser o de insumo ao crescimento econômico e ao aumento da produtividade do trabalho, reafirmando os pressupostos da Teoria do Capital Humano como base para sua concepção de educação, como apontam Mota Júnior e Maués (2014).

Quando analisamos documentos dos OIs, vimos alguns desses indícios presentes nas políticas educacionais do Brasil. Ao considerarmos o documento "Atingindo uma educação de nível mundial no Brasil: próximos passos - Sumário Executivo: Estratégias 2020” do 
Banco Mundial (2011), percebemos a ênfase sobre a necessidade de investimento na melhoria da qualidade dos professores no Brasil, o que exigirá o recrutamento de indivíduos de mais alta capacidade, assim como a busca pelo melhoramento contínuo da prática profissional aliada à recompensa pelo desempenho.

O documento também assinala as habilidades exigidas para o século XXI, a saber, formandos com a capacidade de pensar analiticamente, fazer perguntas críticas, aprender novas habilidades e operar com alto nível de habilidades interpessoais e de comunicação, inclusive com o domínio de idiomas estrangeiros e a capacidade de trabalhar eficazmente em equipes. (BM, 2011, p.5).

Vemos, ao longo da pesquisa, que os OIs, a partir da visão de mundo, de sociedade e de educação que possuem, impõem suas diretrizes e consensos como sendo estatuto de verdades absolutas, pois se constroem como ideias dominantes que explicam e justificam uma dada realidade. No entanto, elas retratam apenas uma aparência, tomada como uma posição de totalidade, quando de fato, são mecanismos utilizados pelo sistema capitalista para mascarar sua essência, pois na realidade se põe invertida, como aponta Fiorin (2005).

Os discursos de eficácia, inclusão social e tecnológica, de gestão democrática, de formação humana, de educação de qualidade, e tantos outros são afirmados em sua aparência fenomênica e, ao mesmo tempo, são negados na sua essência, o que os tornam discursos ideológicos tomando esse conceito na visão mais ampla como coloca Fiorin (2005), uma "visão de mundo", ou seja, "o ponto de vista de uma classe social a respeito da realidade, a maneira como uma classe ordena, justifica e explica a ordem social” (p.31). Essa visão tem origem em Marx e Engels (2009, p. 31) quando postulam que "os homens e suas relações aparecem invertidos, como numa câmara escura".

Vimos que, se por um lado, o PNEGEB busca atender a uma determinação legal, apoiando-se na oferta de pós-graduação lato sensu por meio da modalidade da educação a distância, por outro lado, é também resposta que surge dos anseios de muitos educadores que desejam uma formação continuada e de qualidade. No entanto, atentos aos argumentos de Paro (2001), questionamos sob que condições essas "determinações legais" têm sido desenvolvidas e quais os resultados foram alcançados.

Situando historicamente o PNEGEB, vemos que ele tem início no ano de 2004, no primeiro mandato do governo do Partido dos Trabalhadores (PT). Esse contexto apresenta resquícios da influência das políticas do governo de FHC que, por sua vez, considerou a 
influência dos OIs nas reformas educacionais do Brasil, em especial, políticas em que trouxe profundos impactos aos países da América Latina.

Em termos de política no sentido macro, é possível entender que esses indícios afetam as políticas educacionais. Mota Júnior e Maués (2014) destacam que são impactos "tão profundos que, segundo Oliveira (2009), levaram a constituir uma nova regulação educativa, assentada em três pilares: a gestão local, o financiamento per capita e a avaliação sistêmica”. Esses autores defendem que há, no período de governo dos presidentes Lula-Dilma (PT), em continuidade ao de FHC (PSDB), certa "perspectiva economicista do papel da educação, relacionada tanto sobre a função social enquanto formadora de mão de obra para atender às exigências da economia capitalista do século XXI", quanto também com relação "ao lugar que ela deve ocupar como política pública e a relação que deve estabelecer com o Estado, a iniciativa privada e o orçamento público". (p.11).

Diante desses apontamentos, Mota Júnior e Maués (2014) expressam que se trata de um contexto em que há uma concepção burguesa de sociedade e educação e que, portanto, os "valores liberais fundamentam sua estratégia de consolidação do Estado neoliberal no Brasil e de conformação de um modelo de educação baseado na Teoria do Capital Humano, indispensável para a manutenção da ordem geopolítica internacional” (p.14).

Nesse sentido, a pesquisa compreende que dentre as determinações do PNEGEB, expressas pela experiência no Tocantins, há certamente indícios desses elementos tendo em vista o contexto macro pelo qual é implantado. Contudo, na experiência analisada isso é uma contradição, porque os dados demarcam possibilidades de uma formação que contraria esses princípios, pois é uma experiência que se revela positiva.

Nesse sentido, concordamos com Saviani (2010) quando alerta que a formação de profissionais da educação é também um dos seus desafios a serem enfrentados pelo Sistema Nacional de Educação, e que, para além de estarmos cientes desse alerta e desafio, precisamos "operar um giro da formação" (p.9), no sentido que de que a formação seja ampla e possibilite formação humana e emancipadora.

Numa perspectiva emancipatória, espera-se que essa política possa oportunizar o conhecimento de elementos teóricos e práticos de modo que os coordenadores pedagógicos viabilizem e vivam os princípios de uma educação com qualidade social, como é declarado nos documentos de Diretrizes do PNEGEB e PPC do curso.

Compreendemos que os cursos de formação não podem se restringir ao nível do senso comum na visão gramsciana, como uma postura consensual imposta por uma classe 
hegemônica e dominante a uma classe subalterna, de forma que essa aceite, de forma passiva, os padrões de comportamentos difundidos por aquela.

É importante registrar nosso entendimento de que os sujeitos que participam de uma pós-graduação devem ter tanto o direito de acesso a conhecimentos teóricos e práticos de forma profunda e completa, como também, o direito de vivenciá-los e explorá-los no seu processo de trabalho, de modo a que, por meio da práxis, transformem-se e colaborem para a transformação dos outros e do meio que atuam.

Trata-se de oportunizar espaços de formação em que o profissional seja potencializado como a essência do sistema educacional, como um intelectual orgânico para que tenha condições de auxiliar e conduzir o grupo, ou fração do grupo, à adesão de um novo projeto de educação a partir da elevação da consciência dessa classe que está dispersa em torno dos consensos estabelecidos pelas classes dominantes e que até, de forma ingênua ou inconsciente, aceitam e reproduzem suas determinações como sendo as corretas e as melhores.

Acreditamos que o coordenador pedagógico, por meio do seu direito de ter uma formação coerente às expectativas humanas e emancipatórias, pode contribuir para mudar as situações instituídas e, ao mesmo tempo, auxiliar na geração de um quadro de intelectuais que continuem a luta por um projeto de educação ético e político de forma a assegurar a hegemonia social e o domínio da classe que representa.

Mesmo que seja por meio de políticas inovadoras, mas que sejam emancipadoras e edificantes, como coloca Veiga (2003), porque a inovação, nessa concepção, é uma produção humana, portanto é processual, é dinâmica, é dialética, há intencionalidades pela construção de benefícios para um conjunto de atores.

A experiência do curso de especialização lato sensu no Tocantins mostra que o curso representou uma alternativa de formação para gestores das escolas públicas do Tocantins. Por sua vez, mostra-se também como uma inovação, tendo em vista a falta de regulamentação da função do coordenador pedagógico e, portanto, representa resultados que vão contra os interesses colocados pelos OIs.

Durante a realização da pesquisa, compreendemos que reconfigurações, pelas quais o Estado passa, seguem o curso do processo de expansão do capital, cujo movimento é social, histórico e político e que se trata de um fator que independe dos preceitos e vontades dos indivíduos. Assim, quando um modelo de produção capitalista dá sinais de crises, respostas são criadas para a manutenção desse sistema. 
Uma dessas respostas é a busca por um modelo de produção flexível e orientado pelas diretrizes dos organismos internacionais, que, numa perspectiva do senso comum gramsciano, se apresenta como um consenso hegemônico e ideológico como sendo a única saída para a crise do capital.

No movimento de compreensão dessas determinações, tomamos como referência a teorização de Estado a partir da visão ampliada de Gramsci, para o qual o Estado se refere a um conjunto de organismos públicos que têm como função a dominação direta, quer seja no campo da hegemonia ou da coerção.

A partir dessa concepção de Estado e considerando suas atuais ressignificações, realizamos uma discussão sobre os OIs, de modo a entender suas origens e as formas como elas se atrelam ao papel do Estado e direcionam as políticas públicas de educação brasileira, visando somar as discussões em torno das determinações do PNEGEB e suas implicações para formação de coordenadores pedagógicos.

Vimos que, diante das ressignificações no papel do Estado à luz do ideário neoliberal, há uma diminuição dos direitos sociais, que embora poucos, foram conseguidos com lutas sociais. Isso se expressa pela omissão da presença do Estado nas ações sociais, pela criação de políticas assistencialistas, regulatórias e técnicas, dentre outras marcas que se destacam com a reforma gerencialista do Estado brasileiro e reformas na educação. É nessa perspectiva de atuação do Estado, que as políticas públicas são criadas e executadas, como é o caso do Programa Nacional Escola de Gestores da Educação Básica/PNEGEB.

Considerando que esse Programa financia e apoia a oferta de cursos de formação de professores gestores por meio da modalidade da educação a distância, desenvolvemos também uma reflexão em torno dessa modalidade, utilizando, de um lado, argumentos favoráveis de que a $\mathrm{EaD}$ se apresenta como uma modalidade em que a educação pode ter um caráter emancipador e contribuir para a formação e a transformação de novos indivíduos.

Por outro lado, utilizamos argumentos que são contrários a essa visão e que mostram que a $\mathrm{EaD}$, da forma como tem sido implantada e desenvolvida no Brasil, não está desenvolvendo esses objetivos, considerando que suas bases de sustentação se pautam em um referencial hegemônico e dominante a partir das diretrizes internacionais para o desenvolvimento da sociedade do conhecimento.

Essa não é a perspectiva corroborada por nós, pois concebemos educação como ação humana e emancipadora e, portanto, entendemos que a $\mathrm{EaD}$, para além de ser a distância e usar tecnologias, é antes de tudo educação. Assim, ela também deve promover espaços de 
apropriação da herança cultural historicamente produzida pelos indivíduos por ser objetivada de geração a geração a partir do processo de formação da individualidade, como coloca Duarte (2008), que, com base em Marx (1978), afirma que o indivíduo precisa apropriar-se dos resultados da história e fazer desses resultados os órgãos da sua individualidade.

Os argumentos favoráveis e contrários constituem visões de mundo diferenciadas e se apresentam coerentes a partir de suas concepções que são refletidas a partir da materialidade em que elas são construídas. Considerando que fazem parte de uma totalidade, não podem ser entendidas de forma separada e, portanto, as questões específicas que as determinam foram levadas em consideração.

No entanto, para além dessas concepções estamos cientes, como argumentamos ao longo da pesquisa, que os indivíduos que participam de cursos de formação continuada, seja na modalidade presencial ou a distância, devem ter a oportunidade e o direito de uma formação plena a qual lhe conceda elementos para a construção de um novo senso comum e a partir da consciência política da classe, possam lutar por mudanças e alcançar patamares contra-hegemônicos. Deve ser um intelectual que age no sentido da construção e manutenção de consensos de sua classe a partir de projetos comuns e do desenvolvimento do seu trabalho diário, tendo em vista realizá-lo a partir de um princípio educativo da visão marxiana.

Também estamos cientes que esses objetivos mais amplos de formação com base em uma visão socialista, com princípios de uma educação politécnica, de uma escola unitária ou pela perspectiva histórico-crítica, só serão conseguidos a partir de um novo modelo de educação e de escola, pois a que temos atualmente não tem esses interesses.

Associado a essas reflexões, buscamos evidenciar algumas características do PNEGEB, buscando situá-lo a partir de sua criação, da experiência no Tocantins e, a partir de algumas experiências no Brasil, de forma mais geral. Vimos que esse Programa, como uma das ações da política de formação de professores/gestores, nasce num contexto político e social em que as demandas por formação desses profissionais são enormes, tanto do ponto de vista dos próprios profissionais, quanto da estrutura normativa do Estado, o qual cria ações para o fortalecimento da educação e dos índices necessários de qualidade educacional por intermédio dos acordos estabelecidos nos pactos internacionais.

Identificamos que o PNEGEB, desde sua origem, busca promover ações de formação de gestores como alvo na gestão democrática e que, em termos metodológicos, opta pela educação a distância como modalidade possível para a formação dos profissionais em efetivo exercício das escolas públicas da educação básica. 
Assim, vimos que, pelos discursos dos documentos de criação e execução do curso, a experiência da pós-graduação de coordenação pedagógica desenvolvida no Tocantins no período de 2010-2011 se revela como uma experiência positiva, ou seja, que tenha alcançado os objetivos e perfil esperado a esses profissionais.

Essa também foi a perspectiva das experiências do PNEGEB no Brasil, conforme evidenciamos no mapeamento realizado sobre as pesquisas de mestrados e doutorados selecionadas a partir dos dados disponíveis no Banco de dados da Capes sobre esse Programa. Os resultados dessas pesquisas em âmbito nacional apresentaram respostas positivas sobre o alcance dos objetivos e metas do curso, embora também tenham apresentado sinais de contradições.

$\mathrm{Na}$ exposição das discussões referentes às análises dos questionários que foram aplicados aos egressos, aos professores e ao gestor do curso, identificamos que, numa primeira aparência, as visões mostraram perspectivas contrárias às diretrizes de formação apontadas pelos OIs.

Essas perspectivas foram sendo confirmadas no movimento de análise dos documentos e das respostas dos questionários, associando aos referenciais discutidos ao longo da pesquisa, o que nos leva a concluir que as determinações das políticas de formação para gestores escolares por meio do PNEGEB, da forma como se mostra na experiência do Tocantins, apresentam contradições, mas que elas não expressam uma vinculação aos anseios de formação de indivíduos aptos ao mercado consumidor.

As visões, pelo contrário, mostram as possibilidades de uma formação que, embora não possa ser referenciada ao princípio de uma visão contra-hegemônica gramsciana, apresenta-se como uma experiência diferenciada e inovadora no Tocantins, tendo em vista que oportunizou espaços de formação continuada aos coordenadores pedagógicos de modo que esses passaram a repensar sua função, sua identidade e suas práticas diárias.

Certos de que não chegamos a um ponto final nessa pesquisa, entendemos que o trabalho de pesquisa empreendido até aqui pertence a um dado momento da história da produção de um conhecimento específico, considerando nossos limites e avanços científicos, sobretudo metodológicos, mas reconhecendo que a pesquisa precisa continuar.

Para dar prosseguimento ao debate, sabemos da necessidade de atitudes desveladoras, comprometidas com a sociedade no sentido de mostrar o que está oculto, numa perspectiva crítica. Não é possível confundir conhecimentos objetivos expressos nas Políticas Oficialmente Declaradas - POD, que enfatizam os desejos e interesses de educadores 
originariamente a partir de momentos históricos, como é o caso da formação de professores/gestores, com aquelas que até lemos, achamos que compreendemos, que executamos, vivenciamos, aceitamos como sendo corretas, mas que de fato, não se mostram como são nas Políticas de Fato - POF.

Marx já anunciava algum posicionamento assim a seu tempo:

"Nós, de nossa parte, nos debruçamos com nosso capuz mágico, tapando nossos olhos e nossos ouvidos, para poder negar as monstruosidades existentes". (MARX, 1980, p.5-6).

Para não permanecermos nessa condição, continuemos nossa luta! 


\section{REFERÊNCIAS}

ANDERSON, Pierre. Balanço do Neoliberalismo. In. SADER, Emir, GENTILI, Pablo. (Org.). Pós-Neoliberalismo: as políticas sociais e o Estado democrático. São Paulo, Paz e Terra, 1995.

ANDRADE, José Antônio de. A Formação do Brasil: Dos Primórdios Aos Dias Atuais. São Paulo, Ibero América. Kr, 1999.

ANTUNES, Ricardo. Os Sentidos do Trabalho: ensaio sobre a afirmação e negação do trabalho. São Paulo. Boitempo Editora, 2003.

A Desertificação Neoliberal no Brasil (Collor, FHC e Lula). Campinas, São Paulo. Autores Associados, 2005.

AGUIAR Márcia Ângela da Silvaet al. Diretrizes Curriculares do Curso de Pedagogia no Brasil: Disputas de Projetos no campo da formação do profissional da educação. Educação e Sociedade. Campinas, vol. 27, n. 96 - Especial, p. 819-842, out. 2006. Disponível em http://www.cedes.unicamp.br Acesso, jul 2015.

AGUIAR, Márcia Ângela da Silva. Supervisão Escolar e a Política Educacional. São Paulo, Cortez, 1991.

A Política Nacional de Formação Docente, o Programa Escola de Gestores e o trabalho docente. Educar em Revista, Curitiba, Brasil, n. especial 1, p. 161-172, Editora UFPR, 2010.

. Formação em gestão escolar no Brasil nos anos 2000: políticas e práticas. RBPAE v.27, n.1, p. 67-82, jan./abr. 2011.

ALVORI, Ahlert. Políticas Públicas e Educação na Construção de uma Cidadania participativa, no contexto do debate sobre ciência e tecnologia. EDUCERE - Revista da Educação, vol. 3, n.2, jul./dez. p. 129-148.2003.

ARANHA, Maria Lúcia de Arruda. MARTINS, Maria Helena Pires. Filosofando: Introdução à Filosofia. São Paulo, Moderna, 1993.

ASSOCIAÇÃO BRASILEIRA DE NORMAS TÉCNICAS. NBR 14724: trabalhos acadêmicos: apresentação. Rio de Janeiro, 2011.

. NBR 6024: informação e documentação: numeração progressiva das seções de um documento escrito: apresentação. Rio de Janeiro, 2003.

2003.

NBR 6028: informação e documentação: resumo: apresentação. Rio de Janeiro, 
2003.

. NBR 6027: informação e documentação: sumário: apresentação. Rio de Janeiro,

. NBR 10520: informação e documentação: citações em documentos: apresentação. Rio de Janeiro, 2002.

2002.

NBR 6023: informação e documentação: referências: elaboração. Rio de Janeiro,

AZEVEDO, Janete Maria Lins de. A educação como política pública. $1^{\text {a }}$ ed. Campinas/SP:

Autores Associados, 1991.

A educação como política pública. $3^{\text {a }}$ ed. Campinas/SP: Autores Associados, 2001.

BACELLAR, Thiago Barreto Pereira. A hegemonia em Antônio Gramsci: Controvérsias nas interpretações do conceito central de um pensamento clássico e contemporâneo. Marx e o Marxismo 2011: teoria e prática. Universidade Federal Fluminense - Niterói - RJ, 2011.

BANCO MUNDIAL. La enseñanza superior: las lecciones derivadas de la experiencia (El Desarrolo em La práctica).Washington, D. C. 1995.

. Pryoridades y Strategias para la Educacion. Examen del Banco Mundial. Washington, D. C. 1996.

Atingindo uma Educação de Nível Mundial no Brasil: próximos passos -Sumário Executivo: $\quad$ Estratégias 2020. 2011. Disponível em $<$ http://cenpec.org.br/biblioteca/educacao/estudos-e-esquisas/achieving-world-classeducation--in-brazil-the-next-agenda $>$ Acesso jan 2016.

Aprendizagem para Todos. Estratégia 2020 para a Educação do Grupo Banco Mundial. Resumo Executivo. Washington, D. C. 2011.

. Professores Excelentes. Como Melhorar a Aprendizagem dos Estudantes na América Latina e no Caribe. Grupo do Banco Mundial. Washington, D. C. 2014.

BARRETO, Goulart Raquel, LEHER, Roberto. Do Discurso e das condicionalidades do Banco Mundial, a educação superior "emerge" terciária. Revista Brasileira de Educação, v. 13, n⿳39, p. 423-436, set./dez, 2008. Disponível em $<$ http://www.scielo.br/scielo.php?script=sci_arttext\&pid=S1413-24782008000300002>

Acesso mar 2015.

BARROS, Vinicius Soares de Campos. Algumas Considerações sobre a Teoria Marxista do Estado. Perspectiva Filosófica, vol. II, $\mathrm{n}^{\mathrm{o}}$ 28, p. 1-25, 2008. Disponível em $<$ https://www.ufpe.br/ppgfilosofia/images/pdf/algumasconsideracoes v barros.pdf $>$ Acesso abr 2014.

BASTOS, Remo Moreira Brito. Banco Mundial: Aprendizagem para Todos até 2020 - breves notas sobre uma obstnada estratégia. Contribuciones a las Ciencias Sociales, 2014. 
Disponível em $\quad<$ http://econpapers.repec.org/article/ervcoccss/y 3a2014_3ai_3a201411_3a16.htm $>$ Acesso jan, 2015.

BELLONI, Maria Luiza. Educação a distância. Autores Associados, Campinas, São Paulo, 2008.

BENDRATH, Eduardo Ângelo, GOMES, Alberto Alburqueque. Estado, políticas públicas e organismos internacionais: a educação no foco do debate. Intermeio.v.16, n.32, jul./dez., 2010, p.157-171. Disponível em $<$ http://www.intermeio.ufms.br/revistas/32/32\%20Artigo_11.pdf $>$ Acesso mar 2015.

BENJAMIN, Cassio Correa. Família, Sociedade Civil e Estado na Filosofia do Direito de Hegel. Educação e Filosofia, v. 14, $\mathrm{n}^{\mathrm{o}} \mathrm{s}$ 27/28, p. 89-111. 2000. Disponível em $<\underline{\text { http://www.seer.ufu.br/index.php/EducacaoFilosofia/article/download/736/669 }>\text { Acesso jun }}$ 2014.

BIANCHI, Álvaro. O Conceito de Estado Em Max Weber. São Paulo, Lua Nova, 92: 79104, 2014.

BOBBIO, Norberto. Liberalismo e Democracia. Tradução Marco Aurélio Nogueira. São Paulo, Brasiliense, 2000.

. Marx, o Estado e os clássicos. In: Teoria geral da política: a filosofia política e as lições dos clássicos [Org. Michelangelo Bovero]. Rio de Janeiro: Elsevier, 2000.

BOITO JUNIOR, Armando. BERRINGER, Tatiana. Classes Sociais, Neodesenvolvimentismo e Política Externa Nos Governos Lula e Dilma. Revista de Sociologia e Política, V. 21, $\mathrm{N}^{\mathrm{o}}$ 47: p. 31-18, Set, 2013. Disponível em $<$ http://www.scielo.br/pdf/rsocp/v21n47/04.pdf $>$ Acesso dez 2014.

BONETTI, Lindomar Wessler. A gênese das políticas públicas: princípios e determinantes / Enfim, o que são as políticas públicas e quais são os seus objetivos hoje. In: Políticas públicas por dentro. Ijuí: Unijuí. p.19-66 e 73-89.2007.

BORGES, Rosana Maria Ribeiro. Educação a Distância (ou a Favor da Distância?). InterAção: Revista Faculdade de Educação da UFG, v. 27(2), p.1-54, jul./dez., 2002. Disponível em $<$ http://www.revistas.ufg.br/interacao/article/download/1556/1522 $>$ Acesso set 2013.

BRANDÃO, Nagela Aparecida. DIAS, Edmundo Fernandes. A Questão da Ideologia em Antônio Gramsci. Trabalho \& Educação - vol.16, no 2 - jul / dez - 2007. Disponível em http://portal.fae.ufmg.br/seer/index.php/trabedu/article/viewFile/877/769> Acesso, Fev, 2016.

BRASIL. Constituição Federal de 1988. Promulgada em 5 de outubro de 1988. Disponível em <http://www.planalto.gov.br/ccivil 03/constituicao/constituição.htm> Acesso, 15, jul, 2013.

Lei n. 4.024, de 20 de dezembro de 1961. Fixa as Diretrizes e Bases da Educação Nacional. Diário Oficial da União, Brasília, 1961. 
. Lei n. 5.692, de 11 de agosto de 1971. Fixa diretrizes e bases para o ensino de $1^{\circ} \mathrm{e}$

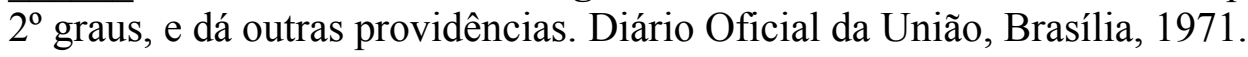

Lei n.9.394/96, de 20 de dezembro de 1996. Diretrizes e Bases da Educação Nacional. Diário Oficial da União, Brasília, 1996.

. MARE. Plano Diretor da Reforma do Aparelho do Estado. Câmera do Aparelho do Estado, Brasília, DF, 1995.

. Parecer $n^{0}$ 252/69. Currículos Mínimos dos cursos de graduação. 4 ed. Brasília: Conselho Federal de Educação. Brasília, DF, 1981.

. Programa Escola de Gestores: Projeto Básico. Brasília: INEP, 2004.

. Parecer $\mathrm{CNE} / \mathrm{CP} \mathrm{n}^{0} 5 / 2005$. Diretrizes Curriculares Nacionais para o Curso de Pedagogia. MEC/CNE, Brasilia, DF, 2005.

- RESOLUÇÃO CNE/CP $\mathrm{n}^{\circ}$ 1, de 15 de Maio de 2006. Institui Diretrizes Curriculares Nacionais para o Curso de Graduação em Pedagogia, Licenciatura. Brasília, DF, 2006.

. Decreto Presidencial n. 6.094, de 24 de abril de 2007. Dispõe sobre a implementação do Plano de Metas Compromisso Todos pela Educação, pela União, em regime de colaboração com municípios, Distrito Federal e Estados. Diário Oficial da União, Brasília, 24 abr. 2007a.

Ministério da Educação. Índice de Desenvolvimento da Educação. 2007.

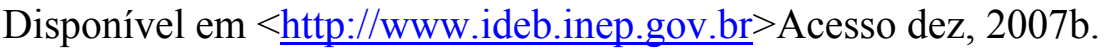

. Ministério da Educação. O Plano de Desenvolvimento da Educação. Razões, Princípios e Programas. Brasília: MEC, 2007c.

Secretaria de Educação Básica. Portaria no 145, de 11 de fevereiro de 2009. Disciplina o Programa Nacional Escola de Gestores da Educação Básica Pública. Diário oficial [da] Presidência da República Federativa do Brasil, Poder Executivo, Brasília, DF, 13 fev. 2009.

. Plano de Metas Compromisso Todos pela educação. - GUIA DE PROGRAMAS. 2007. Ministério da Educação, Brasília, DF. 2007d. Disponível em: $<$ http://planipolis.iiep.unesco.org/upload/Brazil/BrazilGuiadosProgramasdoMEC.pdf $>$ Acesso Mai, 2014.

. Ministério da Educação. Compromisso Todos pela Educação: passo a passo, 2007.

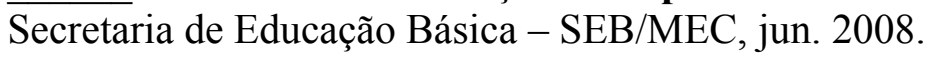

Diretrizes Nacionais do Programa Escola de Gestores da Educação Básica Pública. Brasília/DF: SEB/MEC, 2009a.

Projeto Pedagógico do Curso de Especialização em Coordenação Pedagógica. Brasília: Ministério da Educação, 2009b. 
BRESSER PEREIRA, Luiz Carlos; SPINK, Peter. Reforma do Estado e da administração pública gerencial. São Paulo, Fundação Getúlio Vargas, 2001.

BRZEZINSKI, Iria. Políticas contemporâneas de formação de professores para os anos iniciais do ensino fundamental. Educação e Sociedade. vol.29 n..105 Campinas, Set./Dez. 2008.

. Gestor e gestão democrática em dissertações sobre formação de profissionais da educação: um balanço crítico. ANPAE IBERO-AMERICANO, 2014. Disponível em $<$ http://www.anpae.org.br/IBERO_AMERICANO_IV/GT4/GT4_Comunicacao/IriaBrzezi nski_GT4 integral.pdf $>$ Acesso em set, 2014.

CAPES. Banco de Teses \& Dissertações online. Disponível em $<$ http://bancodeteses.capes.gov.br/banco-teses/\#/> Acesso mai 2016.

CASTRO, Alda Maria Duarte Araújo. Programa Nacional Escola de Gestores da Educação Básica e a Política de Formação de Gestores Escolares. ANPAE, 2012. Disponível em $<$ http://www.anpae.org.br/seminario/ANPAE2012/1comunicacao/Eixo01_19/Alda\%20Maria \%20Duarte\%20Araujo\%20Castro int GT1.pdf>. Acesso jan, 2014.

CASTELO, Rodrigo. O novo desenvolvimentismo e a decadência ideológica do pensamento econômico brasileiro. Serviço Social e Sociedade, São Paulo, n. 112, p. 613-636, out./dez. 2012. Disponível em $<$ http://www.scielo.br/scielo.php?script=sci arttext\&pid=S0101-

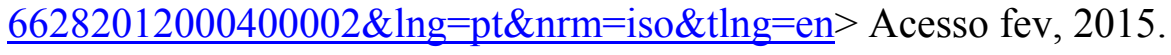

CHAUÍ, Marilena. Estado Civil na filosofia de Hobbes, Locke e Rousseau. Filosofia. Ed. Ática, São Paulo, 2000.

COSTA, Alba Lúcia Nunes Gomes. O Programa Escola de Gestores na UFPB: olhares e propostas dos gestores egressos. 2010, 113f. Dissertação (Mestrado em Educação). Universidade Federal da Paraíba, João Pessoa. 2010.

COSTA, Ricardo. Antônio Gramsci e a Construção da nova hegemonia. Fundação

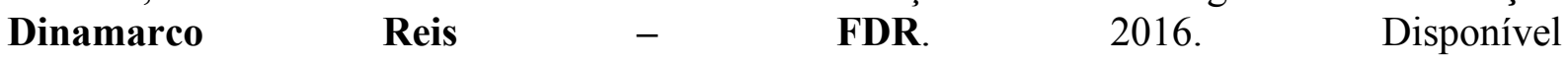
em $<$ https://pcb.org.br/fdr/index.php?option=com_content\&view=article\&id=8:antoniogramsci-e-a-construcao-da-nova-hegemonia\&catid=2:artigos $>$ Acesso ago, 2016.

COUTINHO, Carlos Nelson. O Conceito de vontade coletiva em Gramsci. REV. Katál. Florianópolis. v.12, n.1, p.32-40, jan./jun. 2009.

CUNHA ANTÔNIO, Luís. O Ensino Superior no Octênio FHC. Educação e Sociedade, Campinas, vol. 24, n. 82, p. 37-61, abr. 2003. Disponível em $<$ http://www.scielo.br/pdf/es/v24n82/a03v24n82.pdf> Acesso mai, 2015.

CUNHA BARRICHELO, Renata Cristina Oliveira. O coordenador pedagógico e suas crenças. Educação Unisinos, São Leopoldo, v.9, n.3, 2005. Disponível em

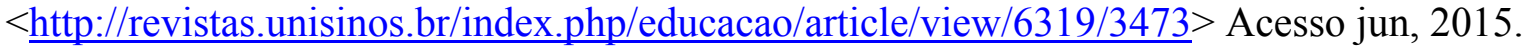


DALVA, Gercina. A política de formação de professores a distância: avaliando o curso lato sensu para gestores escolares (2010-2012). 2015, 205f. Tese (Doutorado em Educação). Universidade Federal do Rio Grande do Norte. Centro de Educação. Programa de Pósgraduação em Educação. 2015.

DALLARI, Dalmo de Abreu. Elementos de Teoria Geral do Estado. São Paulo, Saraiva, 1998.

DOURADO, Luiz Fernandes. Políticas e Gestão da Educação Básica no Brasil: limites e perspectivas.Educação e Sociedade, Campinas, vol. 28, n. 100 - Especial, p. 921-946, out. 2007.

- Políticas e Gestão da Educação Superior a Distância: novos marcos regulatórios.Educação e Sociedade. Campinas, vol. 29, n. 104 - Especial, p. 891-917. 2008.

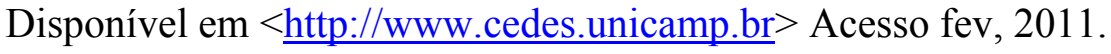

(Org.). Plano Nacional de Educação (2011-2020): avaliação e perspectivas. Goiânia. Ed. UFG; Belo Horizonte. Autêntica Editora, 2011.

DUARTE, Newton. Sociedade do Conhecimento ou Sociedade das Ilusões? Campinas, SP: Autores Associados, 2008. (Coleções polêmicas do nosso tempo).

DRAIBE, Sônia. O Welfare State no Brasil: características e perspectivas. Cadernos de Pesquisa. n.8. Unicamp, São Paulo. 1993.

ENGELS, Friedrich. A origem da família, da propriedade privada e do Estado. Trad. Leandro Konder. 13 ed. Rio de Janeiro, Bertrand Brasil, 1995.

EVANGELISTA, Olinda. Apontamentos para o Trabalho com documentos de política

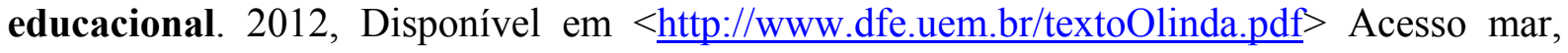
2015.

FAUSTO, Boris. História do Brasil. 2 ed, São Paulo, Editora Universidade de São Paulo, Fundação do Desenvolvimento da Educação, Didática, 1995.

História Concisa do Brasil. São Paulo, Editora Edusp, 2010.

FAORO, Raymundo. Os Donos do Poder: Formação do Patronato Político Brasileiro. $3^{\mathrm{a}}$ ed. São Paulo, Globo, 2001

FERNANDES, Cássia do Carmo Pires. O Programa Escola de Gestores da Educação Básica e seus efeitos para a formação de gestores escolares em Minas Gerais. Tese (doutorado). 2015, 241f. Universidade Federal de Juiz de Fora, Faculdade de Educação, 2015.

FERREIRA, Naura Syria Carapeto. Supervisão Educacional: uma reflexão crítica. 2 ed. Petrópolis: Vozes, 1982.

FERREIRA, Suely. Reformas na Educação Superior: de FHC a Dilma Rousseff (1995-2011). Linhas Críticas, Brasília, DF, n.36, p. 455-472, maio/ago. 2012. 
FILGUEIRAS, Luiz Antônio Mattos. Reestruturação Produtiva, Globalização e Neoliberalismo: capitalismo e exclusão social neste final de século. Mesa-redonda Seminário Interdisciplinar “O Mal-Estar no Fim do Século XX”.Depto de Ciências Humanas e Filosofia da Universidade Estadual de Feira de Santana e pela Escola Brasileira de Psicanálise - Bahia/ Polo Feira.1997.

FIORENTINI, Leda Maria Rangero. Aprender e ensinar com tecnologias, a distância e/ou em 137 ambiente virtual de aprendizagem. IN. SOUZA, Amaralina Miranda de Souza, et al (Org.) Comunidade de Trabalho e Aprendizagem em Rede (CTAR). Brasília: Universidade de Brasília, Faculdade de Educação, 2009.

FIORIN, José Luiz. Linguagem e Ideologia. São Paulo: Ática, 2005 (Série Princípios).

FRANCO, Maria Amélia Santoro. Coordenação Pedagógica: uma Práxis em Busca de sua Identidade. Revista Múltiplas Leituras. v.1, n. 1, p. 117-131, jan. / jun. 2008

FREITAS, Helena Costa Lopes de. Formação de professores no Brasil: 10 anos de embate entre projetos de formação. Educação e Sociedade, Campinas, n.23 (80- especial), p.137$168,2002$.

A (nova) política e formação de professores: a prioridade postergada. Educação e Sociedade e Campinas, vol.28, n.100, p. 1203-1230, out. 2007.

FREUND, Julien. Sociologia de Max Weber. Tradução de Luiz Cláudio de Castro e Costa. Rio de Janeiro, Forense Universitária, 2003.

FRIGOTTO, Gaudêncio. O enfoque da dialética materialista histórica na pesquisa educacional. In: Fazenda, Ivani (Org.). Metodologia da pesquisa educacional. São Paulo: Cortez, 1991.

Educação e a Crise do Capitalismo Real. São Paulo:Cortez, 2000.

. Educação e Trabalho: bases para debater a Educação Profissional Emancipador. Perspectiva, Florianópolis, v.19, n.1, p.71-87, jan./jun. 2001.

. Teoria e Práxis e o Antagonismo entre a Formação Politécnica e as Relações sociais. Trabalho, Educação e Saúde, Rio de Janeiro, v. 7, Suplemento, p. 67-82, 2009.

GIL, Antônio Carlos. Métodos e Técnicas de Pesquisa Social. São Paulo, Atlas, 2012.

GOMES, Luiz Roberto. EaD e a legitimação do saber técnico-científico na educação superior brasileira. In. SOUZA, Dileno Dustan Lucas de.; SILVA JÚNIOR, João dos Reis; FLORESTA, Maria das Graças Soares (ORGs). Educação a distância: diferentes abordagens críticas. São Paulo: Xamã, 2010.

GOMES, Romeu. Análise de Dados em Pesquisa Qualitativa. In. In. MINAYO, Cecília de Souza (Orgs). Pesquisa Social: Teoria, Método e Criatividade. 16 ed. 2000.

. Análise e Interpretação de Dados de Pesquisa Qualitativa. In. MINAYO, Cecília de Souza (Orgs). Pesquisa Social: Teoria, Método e Criatividade. 31 ed. 2012. 
GOMIDE, Angela Galizzi Vieira. Políticas da Unesco para formação de Professores no Brasil: uma leitura da desqualificação da educação brasileira. Cadernos de Pesquisa, n. 11, p. 7, 2010.

GRANCINDO, Regina Vieira. O gestor escolar e as demandas da gestão democrática. Exigências, práticas, perfil e formação. Revista Retratos da Escola, Brasília, v. 3, n. 4, p. 135-147, jan./jun. 2009. Disponível em: <http//www.esforce.org.br>, Acesso mar, 2010.

GRAMSCI, Antônio. Os Intelectuais e a Organização da Cultura. Tradução de Carlos Nelson Coutinho. Civilização Brasileira, 4ª ed. Rio de Janeiro, 1982.

Cadernos do Cárcere. Introdução ao estudo da filosofia. A filosofia de Benedetto Croce.Tradução de Carlos Nelson Coutinho. Volume 1. Civilização Brasileira, Rio de Janeiro, 1999.

Cadernos do Cárcere. Os intelectuais. O princípio educativo. Jornalismo. Tradução de Carlos Nelson Coutinho. Volume 2.3 ${ }^{\mathrm{a}} \mathrm{ed}$, Rio de Janeiro: Civilização Brasileira, 2004.

Cadernos do Cárcere. Maquiavel - Notas sobre o Estado e a Política. Edição e Tradução de Carlos Nelson Coutinho. Volume 3. $7^{\mathrm{a}}$ ed. Rio de Janeiro: Civilização Brasileira, 2016.

GROPPO, Antonio Luiz. Das Origens ao colapso do Estado de Bem-Estar: Uma Recapitulação Desmistificadora. Revista HISTEDBR On-line, Campinas, n.20, p. 68 - 75, dez. 2005.

HEGEL, Georg Wilhelm Friedrich. Princípios da filosofia do direito. Trad. OrlandoVitorino. São Paulo: Martins Fontes, 1997.

. Fenomenologia do Espírito. Petrópolis: Vozes: Bragança Paulista: Editora Universidade São Francisco, 2005.

HARVEY, David. Condição Pós-Moderna. São Paulo, Loyola, 2000.

HAYEK, Friedrich. O caminho da servidão. Traduzido por Anna Maria Capovilla, José Ítalo Stelle e Liane de Morais Ribeiro. São Paulo, Instituto Ludwig von Mises Brasil. 6 ed, 2010 .

HOBBES, Thomas de Malmesbury. Leviatã ou Matéria, Forma e Poder de um Estado Eclesiástico e Civil. São Paulo, Ed. Nova Cultura, 1997.

HÖFLING. Eloisa Maria. Educação e a Crise do Capitalismo Real. São Paulo: Cortez, 2000 .

. Estado e Políticas (Públicas) Sociais. Cadernos Cedes. Ano XXI, $\mathrm{n}^{\mathrm{o}}$ 55, novembro/2001, 30-41.

HORTA, Patrícia Rossi Torralba. Identidades em jogo: duplo mal-estar das professoras e das coordenadoras pedagógicas do ensino fundamental na constante construção de seus papéis. 
Dissertação (Mestrado em Educação). Programa de Pós-Graduação em Educação. Universidade de São Paulo - USP, 2007.

HÚNGARO, Edson Marcelo. A questão do método na constituição da teoria social de Marx. In. CUNHA, Célio da, SOUSA, José Vieira de., SILVA, Maria Abádia da. (Orgs.) O Método Dialético na Pesquisa em Educação. Coleção Políticas Públicas de Educação. Campinas, SP: Autores Associados/Brasília, DF: FE, UnB, 2014.

IGLÉSIAS, Francisco. História Geral e do Brasil. São Paulo, Editora Ática S. A. 1989.

LIBÂNEO, José Carlos; PIMENTA, Selma Garrido. Formação de profissionais da educação: visão crítica e perspectiva de mudança. Educação \& Sociedade, Campinas, v. 20, n. 68, p. 239-277, dez. 1999.

LIBÂNEO, José Carlos. Educação escolar: políticas, estrutura e organização. São Paulo: Cortez, 2003.

LIGUORI, Guido. Estado e Sociedade Civil de Marx a Gramsci. Novos Rumos. Ano 21, $\mathrm{n}^{\mathrm{o}}$ 46, 2006.

LIMA, Elma Correa de. Um olhar histórico sobre a supervisão. In. RANGEL, Mary (Org.). Supervisão Pedagógica: princípios e práticas. Campinas, São Paulo, Papirus, 2001.

LIMA, Glauciene Sebastiana Nogueira. Políticas Educacionais de Formação Continuada: estudo a partir dos projetos de intervenção desenvolvidos no curso de Especialização em Gestão Escolar/UFOPA. 2014, 122f. Dissertação (Mestrado em Educação). UFOPA, Porto Velho/RO, 2014.

LIMA, Kátia Regina Lima de Sousa. Reforma da Educação Superior nos anos de contrarevolução neoliberal: Fernando Henrique Cardoso a Luis Inácio Lula da Silva. Tese (Doutorado em Educação) - Universidade Federal Fluminense. Faculdade de Educação, 462f, 2005.

Educação a Distância na Reformulação da Educação Superior Brasileira. In: NEVES, Lúcia Maria Wanderley. SIQUEIRA, Ângela Carvalho de (Orgs.). Educação Superior: uma reforma em processo. São Paulo: Xamã, 2006.

LIMA, Paulo Gomes. SANTOS, Sandra Mendes dos. O Coordenador Pedagógico na educação Básica: Desafios e Perspectivas. Educere et Educare. Vol. 2, jul/dez., p. 77-90. 2007.

LOCKE, Jhon. Segundo Tratado sobre o governo civil e outros escritos. Ensaio sobre a origem e os fins verdadeiros do governo civil. Petrópolis, Vozes, 1994.

LOMBARDI, José Claudinei. SAVIANI, Demerval. Marxismo e educação: debates contemporâneos. Campinas, SP: Autores Associados: HISTEDBR, 2005.

LUCENA, Carlos. Tempos de destruição: educação, trabalho e indústria do petróleo no Brasil. Campinas, SP: Autores Associados; Uberlândia, MG: EDUFU, 2004. 
MACIEL, David. "De Lula à Dilma Roussef: crise econômica, hegemonia neoliberal e regressão política", 2013. Disponível em $<$ http://marxismo21.org/10-anos-de-governos-do-ptnatureza-de-classes-eneoliberalismo/> Acesso out, 2015.

MAGRONE, Eduardo. Gramsci e a educação: a renovação de uma agenda esquecida.Caderno Cedes, Campinas, vol. 26, n. ${ }^{\circ}$ 70, p. 353-372, set./dez. 2006. Disponível em<http://www.scielo.br/pdf/ccedes/v26n70/a05v2670.pdf $>$ Acesso abr, 2015.

MALANCHEN, Júlia. UNESCO: Políticas e estratégias para formação docente a distância no Brasil. Revista HISTEDBR Online, Campinas, n.32, p.179-199. Dez., 2008.

MATE, Cecília Hanna. O coordenador pedagógico e as relações de poder na escola. In: ALMEIDA, Laurinda Ramalho de. PLACCO, Vera Maria Nigro de Souza. (Org.). O coordenador pedagógico e o cotidiano da escola. São Paulo: Loyola, 2003.

MARCONI. Marina de Andrade. LAKATOS, Eva Maria. Fundamento de Metodologia Científica. 6a Ed. São Paulo, Atlas, 2007.

MARTINS, José de Souza. O poder do atraso: ensaios de sociologia da história lenta. São Paulo: Hucitec, 1994.

MARTINS, Ligia Márcia. As Aparências Enganam: divergências entre o materialismo histórico dialético e as abordagens qualitativas de pesquisa. In. Reunião Anual da ANPED, 29a , 2006, Caxambu, MG. Anais da 29a Reunião Anual da ANPED, Caxambu, MG, 2006. GT17, disponível em <http://29reuniao.anped.org.br/>, Acesso mai, 2016.

MARTINS, Marcos Francisco. Conhecimento e disputa pela hegemonia: reflexões em torno do valor ético-político e pedagógico do senso comum e da filosofia em Gramsci. IN. SAVIANI, Dermeval. LOMBARDI, José Claudinei. (Orgs.) Marxismo e Educação: debates contemporâneos. Campinas, SP: Autores Associados, p. 123-159, 2005.

MARX, Karl. O capital: crítica da economia. Volume I, São Paulo: Civilização Brasileira, 1980.

Apresentação/Crítica da filosofia do direito de Hegel. (§§ 261-313). In:

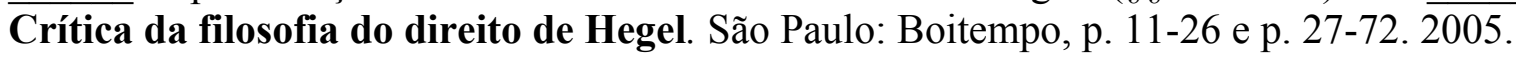

Contribuição à crítica da economia política. Tradução e Introdução de Florestan Fernandes. 2a. Ed. São Paulo: Expressão Popular, 2008.

Contribuição à crítica da filosofia do direito de Hegel: Introdução. Tradução de Lúcia Ehlers. 1. Ed. São Paulo: Expressão Popular, 2010.

Trabalho Assalariado e Capital \& Salário, Preço e Lucro. $2^{\text {a }}$ ed. São Paulo, Expressão Popular, 2010. Reimpresão, 2012.

MARX, Karl. ENGELS, Friederich. Manifesto do Partido Comunista. $1^{a}$ ed., São Paulo. Expressão Popular. 2008. 
Ideologia Alemã. Teses sobre Feurbach. Tradução de Álvaro Pina. 1.ed. São Paulo: Expressão Popular, 2009.

A Sagrada Família. Trad. BACKES, Marcelo. São Paulo: Boitempo, 2011.

MASON, Gisele. As contribuições do método materialista histórico e dialético para a pesquisa sobre políticas educacionais. Anais da IX ANPED SUL, 2012. Disponível em $<$ http://www.ucs.br/etc/conferencias/index.php/anpedsul/\%209anpedsul/paper/viewFile/966/1 26>, Acesso mai, 2015.

MELO, Darci Barbosa Lira de. Formação do gestor escolar em cursos de pós-graduação: análise da experiência da Escola de Gestores da educação básica em Pernambuco. 2014, $214 f$. Tese (Doutorado em Educação) Universidade Federal de Pernambuco. Programa de Pósgraduação em Educação, 2014.

MEC. Ministério da Educação. Secretaria de Educação a Distância. Referenciais de qualidade para educação superior a distância. Brasília: MEC/SEED. 2007.

Programa Nacional de Formação e Certificação de Diretores Escolares

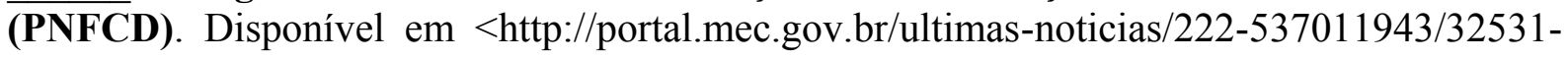
diretores-terao-programa-de-formacao-continuada-e-extensao $>$ Acesso mai, 2016.

MENDONÇA, Sônia Regina de. SOCIEDADE CIVIL EM GRAMSCI: Venturas e Desventuras de um Conceito. VII Simpósio Nacional Estado e Poder, Sociedade Civil. Uberlândia, $\quad$ MG, 2012.Disponível em $<$ http://www.historia.uff.br/estadoepoder/7snep/conferencia.htm>, Acesso mar, 2016.

. O Estado Ampliado como Ferramenta Metodológica. Marx e o Marxismo. v.2, n.2, $\overline{\mathrm{jan} / \mathrm{jul},} \quad 2014 . \quad$ Disponível em $<$ http://www.marxeomarxismo.uff.br/index.php/MM/article/view/35/32>, Acesso abr, 2016.

MIZIARA, Leni Aparecida Souto. A coordenação Pedagógica e a Práxis Docente. (Dissertação de Mestrado) - Universidade Católica Dom Bosco, Campo Grande, MS, 192f, 2008.

A função do Coordenador de Área do Programa Além das Palavras. Tese (Doutorado em Educação Escolar) - Universidade Estadual Paulista "Júlio de Mesquita Filho", Faculdade de Ciências e Letras, 289f, 2014.

MOTA JÚNIOR, Wilhian Pessoa da.; MAUÉS, Olgaíses Cabral.; O Banco Mundial e as Políticas Educacionais Brasileiras. Educação \& Realidade, Porto Alegre, v. 39, n. 4, p. 1137-1152, out./dez. 2014.

MORAES, Raquel de Almeida. O método materialista dialético e a consciência. In: CUNHA, Célio da; SOUSA, José Vieira de; SILVA, Maria Abádia da. (Orgs.). O método dialético na pesquisa em educação. (Col. Políticas Públicas de Educação). $1^{\text {a }}$ ed. Campinas: Autores Associados, 2014, v. 1, p. 79-96. 
. Educação a Distância: aspectos histórico-filósoficos. In. FIORENTINI, Leda Maria Rangero, MORAES, Raquel de Almeida, (ORGs.). Linguagens e interatividade na educação a distância. Rio de Janeiro: DP\&A, 2003.

. Educação, Trabalho e Novas Tecnologias na Educação a Distância: uma reflexão crítica. Revista HISTEDBR On-line, v. 65, p. 103-112, 2015.

Gramsci and Culture. In: Michael Peters. (Org.).Encyclopedia of Educational Philosophy and Theory.1ed. Heidelberg: Springer, 2016, v. 1, p. 1-5.

MORAES Raquel Almeida, PEREIRA EvaWaisros. A política de educação a distância no Brasil e os desafios na formação de professores na educação superior. Seminário do Histedbr. Eixo2. História, políticas públicas e educação. 2009. Disponível em $<$ http://www.histedbr.fe.unicamp.br/acer_histedbr/seminario/seminario8/_files/mBv36y8F.do c.> Acesso jan, 2016.

NASCIMENTO, Maria Isabel Moura. SBARDELLOTO, Denise Kloeckner. A Escola Unitária: Educação e Trabalho em Gramsci. Revista HISTEDBR On-line, Campinas, n.30, p.275-291, jun.2008. Disponível em $<$ http://www.histedbr.fe.unicamp.br/revista/edicoes/30/art17_30.pdf> Acesso mai, 2016.

NASCIMENTO, Leandro Gileno Militão. Políticas públicas de formação do gestor escolar na rede municipal de Salvador-BA: uma análise do curso de gestão escolar. Dissertação (Mestrado). 99fls. Il. Programa de Pós-Graduação Gestão e Tecnologia Aplicada (GESTEC), Universidade do Estado da Bahia (UNEB). Salvador, 2015.

NASCIMENTO, Lindalva Gouveia. As contribuições do Curso de Especialização da Escola de Gestores para o exercício da gestão escolar democrática. 2012, $132 \mathrm{f}$. Dissertação (Mestrado em Educação). Universidade Federal da Paraíba, João Pessoa. 2012.

NEDER, Maria Lúcia Cavalli. A educação a distância e a formação de professores: Possibilidade de mudança paradigmática. In. PRETI, Oeste (Org.). Educação a Distância: sobre discursos e práticas. Brasília, Liber Livro Editora, 2005.

NEVES, Lúcia Maria Wanderley, SIQUEIRA, Ângela Carvalho. (Orgs). Educação Superior: uma reforma em processo. São Paulo, Xamã, 2006.

NEVES, Lucia Maria Wanderley, PRONKO, Marcela Alejandra. O Mercado do Conhecimento e o Conhecimento para o Mercado: da formação para o trabalho complexo no Brasil contemporâneo. Rio de Janeiro. EPSJV, 2008.

OLIVEIRA, Elsa Guimarães. Educação a Distância na Transição Paradigmática. Campinas, São Paulo, Papirus, 2003.

OLIVEIRA, Daniela Motta de. Educação a Distância e a formação de professores em nível superior no Brasil. Anais da ANPED, 32, GT11, 2009.

OLIVEIRA, Dalila Andrade. Política Educacional e Regulação no Contexto Latinoamericano: Argentina, Brasil e Chile. Linhas Críticas (UnB), Brasília, v. 15, n. 28, p. 45-62, jan./jun. 2009. 
OLIVEIRA, Beatriz Alves de. Gestão educacional pós-municipalização: práticas patrimonialistas, poder e outros desafios na ótica dos gestores. 2011. 113f. Dissertação (Mestrado em Educação). UFSC. 2011.

OTRANTO, Regina Célia. A Reforma da Educação Superior do Governo Lula: da inspiração à implantação. Anais da ANPED 29, GT11, 2006.

PÁDUA, Elizabete Matalho Marchesini de. Metodologia da Pesquisa: abordagem teóricoprática. Campinas, São Paulo, Papirus, 2004.

PARO, Vitor Henrique. Administração escolar: introdução crítica. São Paulo: Cortez: Autores Associados, 1986.

. Gestão da Escola Pública: a Participação da Comunidade. Rev. Bras. Est. Pedag., Brasília, v.73, n.174, p.255-290, maio/ago. 1992.

Escritos sobre Educação. São Paulo: Xamã, 2001.

Implicações do caráter político da educação para a administração da escola pública. Educação e Pesquisa, São Paulo, v.28, n.2, p. 11-23, jul./dez. 2002.

. José Querino Ribeiro e o paradoxo da administração escolar. Revista Brasileira de Política e Administração da Educação, Porto Alegre, v. 23, n. 3, p. 561-570, set./dez. 2007.

. A educação, a política e a administração: reflexões sobre a prática do diretor de escola. Educação e Pesquisa, São Paulo, v. 36, n.3, p. 763-778, set./dez. 2010

Progressão continuada, supervisão escolar e avaliação externa: implicações para a qualidade do ensino. Revista Brasileira de Educação, v. 16 n. 48 set./dez. 2011.

PAULO NETTO, José. Introdução ao estudo do método de Marx. 1ed. São Paulo: Expressão Popular, 2011.

PEREIRA, Aline Gabriele. Os tempos e espaços do gestor escolar em formação na educação a distância. 2013, 165f. Dissertação (Mestrado em Educação). Universidade Federal de Minas Gerais, 2013.

PEREIRA DA SILVA, Marcelo Soares. Políticas e Práticas de Formação de Gestores Escolares Frente às novas DCN para o Curso de Pedagogia. ANPAE Simpósio. 2007.

PEREIRA, Eva Wairos, MORAES, Raquel Almeida. História da educação a distância e os desafios na formação de professores no Brasil. In.: SOUZA, Amaralina Miranda (Orgs). Comunidade de Trabalho e Aprendizagem em Rede (CTAR). Brasília: Universidade de Brasília, Faculdade de Educação, 2009.

PERONI, Vera Maria Vidal. CAETANO, Maria Raquel. Redefinições no Papel do Estado: Terceira Via, Novo Desenvolvimentismo e as Parcerias Público-Privadas na Educação. Revista da FAEEBA - Educação e Contemporaneidade, Salvador, v. 21, n. 38, p. 57-67, jul./dez. 2012. 
PINTO, Céli. As conferências nacionais no governo Lula: limites e possibilidades da construção de uma esfera pública. ENCONTRO ANUAL DA ANPOCS, v. 30, 2006.

PIRES, Ennia Débora Passos Braga. A prática do coordenador pedagógico: limites e perspectivas. Dissertação (Mestrado em Educação) - Universidade Estadual de Campinas, Faculdade de Educação. Campinas, São Paulo, 216f. 2005.

PLACCO, Vera Maria Nigro de Souza; ALMEIDA, Laurinda Ramalho de. SOUZA, Vera Lúcia Trevisan de. (Org.). O coordenador pedagógico e o cotidiano da escola. São Paulo: Loyola, 2010.

PLACCO, Vera Maria Nigro de Souza. SOUZA, Vera Lúcia Trevisan de. ALMEIDA, Laurinda Ramalho de. O coordenador Pedagógico e a Formação de Professores: Intenções, Tensões e Contradições. Relatório da Pesquisa desenvolvida pela Fundação Carlos Chagas por encomenda da Fundação Victor Civita. 2011. 135p.

. Coordenador Pedagógico: Aportes à Proposição de Políticas Públicas. Cadernos de Pesquisa, v.42, n.147, p.754-771, set./dez, 2012.

Proposições de Políticas públicas quanto à formação de coordenadores pedagógicos, formadores de professores. XVI ENDIPE - Encontro Nacional de Didática e Práticas de Ensino - UNICAMP - Campinas - 2012. Junqueira\&Marin Editores Livro 2. 2012a, Disponível em <http://www.infoteca.inf.br/endipe/acervo/listar/pesquisar> , Acesso mar, 2014.

Legislado versus executado: análise das atribuições formativas do coordenador pedagógico. Est. Aval. Educ., São Paulo, v. 27, n. 64, p. 70-94, jan./abr. 2016.

PORTAL MEC. Histórico do Programa Escola de Gestores. Disponível em $<$ http://portal.mec.gov.br/escola-de-gestores-da-educacao-basica/historico $>$ Acesso abr, 2015.

PRETI, Oreste. Educação a Distância e Globalização: tendências e desafios. Revista Brasileira de Estudos Pedagógicos. Brasília, v. 79, n. 191, p. 19-30, jan./abr. 1998.

RAMOS, Wilsa Maria, MEDEIROS, Larissa. A Universidade Aberta do Brasil: desafios da construção do ensino e da aprendizagem em ambientes virtuais. In.: SOUZA, Amaralina Miranda (Orgs). Comunidade de Trabalho e Aprendizagem em Rede (CTAR). Brasília: Universidade de Brasília, Faculdade de Educação, 2009.

RAMOS, Patrícia Cavalcanti. Pesquisa em Educação: o método Survey. Trabalho de Conclusão do curso de Pedagogia da Universidade Estadual de Londrina, PR, 2011.

RODRIGUES, Gisele Cristina. A prática pedagógica dos gestores escolares: a implementação da Escola de Gestores UFMG no polo Montes Claros, MG. 2015, $123 f$. Dissertação (Mestrado em Educação). Universidade Federal de Minas Gerais, 2015.

ROMAN, Marcelo Domingues. O coordenador pedagógico e o cotidiano escolar: um estudo de caso etnográfico. (Dissertação de Mestrado). Universidade de USP -Departamento de Psicologia da Aprendizagem, do Desenvolvimento e da Personalidade, 2001. 
ROMANOWSKI Joana Paulina; ENS, Romilda Teodora. As pesquisas denominadas do tipo "Estado da Arte" em Educação. Revista Diálogo Educacional, vol. 6, núm. 19, set-dez, 2006, pp. 37-50.

ROSSEAU, Jean Jacques. Do contrato social - ensaio sobre a origem das línguas. São Paulo. Ed. Nova Cultural, 1997. Livro Primeiro.

ROIO, Marcos Tadeu Del. Globalização e o Estado Nacional. Marília. UNESP, 1999.

SANTOS, Catarina Almeida. Expansão da educação superior rumo à expansão do capital: interfaces com a educação a distância. 2008. 126 f. Tese (Doutorado em Educação) Faculdade de Educação - Universidade de São Paulo. São Paulo, 2008.

SAVIANI, Demerval. Sobre a concepção de politecnia. Rio de Janeiro: FIOCRUZ. Politécnico da Saúde Joaquim Venâncio, 1989. mar. 2002.

O choque teórico da politecnia. Trabalho, Educação e Saúde, v. 1, n. 1, p. 131-152,

A Nova Lei da educação (LBD): trajetória, limites e perspectivas. $8^{\mathrm{a}}$ ed. Campinas, Autores Associados. 2003.

Perspectiva Marxiana do Problema Subjetividade-Intersubjetividade. Conferência - I Seminário Internacional sobre Filosofia e Educação. Passo Fundo, 2003. Disponível em: $<$ http://www.escolapcdob.org.br/file.php/1/materiais/pagina_inicial/Biblioteca/76_SAVIANI_ Dermeval_-_Perspectiva_marxiana_do_problema_da_subjetividade-intersubjetividade.pdf $>$, Acesso jan, 2015.

Pedagogia histórico-crítica: primeiras aproximações. 9. ed. Rev. e ampl. Campinas: Autores Associados, 2005.

A supervisão educacional em perspectiva histórica: da função à profissão pela mediação da ideia. In: FERREIRA, Naura Syria Carapeto. (Org.). Supervisão educacional para uma escola de qualidade. 4. ed. São Paulo: Cortez, 2007a.

Trabalho e educação: fundamentos ontológicos e históricos. Revista Brasileira de

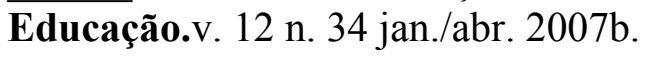

Entrevista: Regime de colaboração é o caminho para organizar o sistema nacional de educação. Observatório da Educação, 2009. Disponível em $<$ http://www.observatoriodaeducacao.org.br/index.php/entrevistas/56-entrevistas/707-regimede-colaboracao-e-o-caminho-para-organizar-o-sistema-nacional-de-educacao->, Acesso mai, 2011.

. Sistema Nacional de Educação articulado ao Plano Nacional de Educação. Revista Brasileira de Educação, v. 15 n. 44 maio/ago. 2010. Disponível em $<$ http://www.scielo.br/pdf/rbedu/v15n44/v15n44a13.pdf> Acesso jul, 2015.

História das ideias pedagógicas no Brasil. 3.ed. Campinas, SP: Autores Associados, (Coleção memória da educação), 2011a. 
Pedagogia histórico-crítica: primeiras aproximações. 11. ed. rev.- Campinas, SP: Autores Associados, (Coleção educação contemporânea), 2011b.

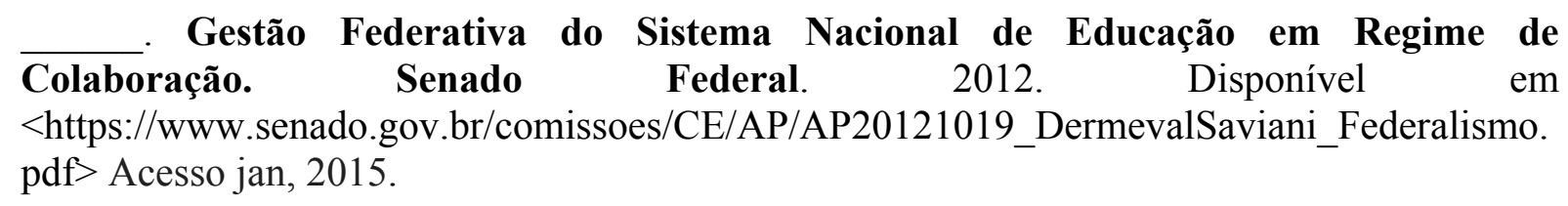

SEMEARO, Giovani. Da sociedade de massa à sociedade civil: A concepção da subjetividade em Gramsci. Educação \& Sociedade, ano XX, no 66, Abril/99. 1999. Disponível em $<$ http://www.scielo.br/pdf/es/v20n66/v20n66a3.pdf.> Acesso jan, 2016.

SERIGHELLI, Marco André. Concepções sobre gestão escolar entre os egressos do curso de especialização em gestão escolar do polo de Joaçaba. 2009, 76f. Dissertação (Mestrado em Educação) Universidade do Oeste de Santa Catarina, 2009.

SEVERINO, Antônio Joaquim. Educação, Ideologia e Contra-ideologia. São Paulo: EPU, 1986.

SHIROMA, Eneida Oto. A Formação do Professor-gestor nas políticas de profissionalização. Revista e-curriculum, São Paulo, v.7, n.2, Agosto, 2011. Disponível em < http://revistas.pucsp.br/index.php/curriculum>, Acesso abr, 2012.

SILVA, Carmem Silva Bissollida. Curso de Pedagogia no Brasil: História e Identidade. Campinas, São Paulo. Autores Associados, 2006.

SILVA, Maria Aldeizada. Formação Lato sensu a Distância em Gestão Escolar. 2015. Tese (Doutorado em Educação). UFRN. Centro de Educação. Programa de Pós-graduação em Educação. 2015.

SILVA, Renata Gomes da Silva. OLIVEIRA, Eloíza Silva Gomes de, COSTA, Gabriela Gomes da Silva. Os Dilemas do Estado e da Política Pública: Políticas Públicas de EaD, Tecnologia e Reforma Universitária. Anais do VIII Convibra Administração - Congresso Virtual Brasileiro de Administração. 2011. Disponível em <http:// www.convibra.com.br>. Acesso jul, 2013.

SILVA, Maria Abadia da. A Hegemonia do Banco Mundial na Reformulação e no Gerenciamento das Políticas Educacionais. Nuances, vol. VI, p. 35-53, out. 2000.

SILVA, Sheyla Suely de Souza; NÓBREGA, Mônica Barros da; FONSECA, Cleomar Campos da. Hegel: suas contribuições ao conhecimento, sua discussão sobre o Estado e a (im)pertinência de suas análises para o Estudo do Estado Contemporâneo. Qualit@s Revista Eletrônica, Vol.1. Nº1, 2011.

SILVA JÚNIOR, João dos Reis. Reformas do Estado e da educação e as políticas públicas para a formação de professores a distância: implicações políticas e teóricas. Revista Brasileira de Educação, Rio de Janeiro, n.24, p.78-89, set./dez.2003.

Políticas públicas para formação de professores a distância: implicações políticas e teóricas. In. SILVA JÚNIOR, João dos Reis da. SOUZA, Dileno Dustan Lucas. FLORESTA, 
Maria das Graças Soares. (Orgs.) Educação a Distância: diferentes abordagens críticas. São Paulo. Xamã, 2010.

. Reforma do Estado e da Educação no Brasil de FHC. SP: Xamã, 2002.

. Pragmatismo e Populismo na educação Superior: nos governos FHC e Lula. São Paulo, Xamã, 2005.

SILVA JÚNIOR, João dos Reis. SGUISSARDI, Valdemar. Novas faces da educação superior no Brasil: reforma do Estado e mudanças na produção. Cortez Editora, São Paulo, 2001.

SILVA JÚNIOR, João dos Reis; KATO, Fabíola B. Grello; SANTOS, Silvia Alves dos. Políticas públicas para formação de professores a distância: implicações políticas e teóricas. Educação a distância: diferentes abordagens críticas. São Paulo: Xamã, p. 33-52, 2010.

SOUSA, José Vieira de. Teoria Política: Relação Estado e Educação. VEREDAS, Projeto de Formação de Professores em nível superior. Belo Horizonte: SEMG, 2007.

Abordagens metodológicas no estudo de políticas educacionais: o caso do Programa de Pós-Graduação em Educação da Universidade de Brasília (2010-2012). In. CUNHA, Célio da., SOUSA, José Vieira de., SILVA, Maria Abádia da. (Orgs.) O Método Dialético na Pesquisa em Educação. Coleção Políticas Públicas de Educação. Campinas, SP: Autores Associados/Brasília, DF: FE, UnB, 2014.

SOUZA, Raquel Aparecida. Da Unitins à UFT: Modelos e Práticas Gestoriais presentes na Educação Superior do estado do Tocantins no Limiar do Século XXI. Dissertação (Mestrado em Educação). Universidade Federal de Uberlândia (UFU), 2007.

SCHWARTZMAN, Simon. Bases do Autoritarismo Brasileiro. Rio de Janeiro, Camous, 1998.

TEIXEIRA, Marilza Aparecida Pereira. Formação para diretor escolar da educação básica: o Programa Nacional Escola de Gestores no Estado do Paraná. 2011, 133f. Dissertação (Mestrado em Educação). Universidade Federal do Paraná, 2011.

TRIVIÑOS, Augusto Nibaldo Silva. A dialética materialista e a prática social. Movimento. Porto Alegre. v. 12, p. 121-142, 2006. Disponível em: http://www.revistas.ufg.br/index.php/interacao/issue/view/1522/showToc. Acesso set, 2014.

Introdução à pesquisa em ciências sociais: a pesquisa qualitativa e educação. 1. Ed. 21 reimp. São Paulo: Atlas, 2012.

VASCONCELLOS, Celso dos Santos. Projeto de ensino e aprendizagem e projeto político pedagógico - elementos metodológicos para elaboração e realização. 10. ed. São Paulo: Libertad, 2002.

Coordenação do trabalho pedagógico: do projeto político-pedagógico ao cotidiano da sala de aula. São Paulo: Libertad, 2002. 
. Construção do Conhecimento em Sala de Aula, 18a ed. São Paulo: Libertad, 2012.

(In) Disciplina: problema de gestão da sala de aula ou de auto-organização dos alunos? In: Coordenação do Trabalho Pedagógico: do projeto político-pedagógico ao cotidiano da sala de aula,12a ed. São Paulo: Libertad, 2012.

WEBER, Max. Economia e Sociedade: Fundamentos da Sociologia Compreensiva. Traduzido por Regis Barbosa e Karen Barbosa. Vol. 1. Brasília, DF, Editora da Universidade de Brasília, 1991.

. Metodologia das Ciências Sociais. Traduzido por Augustin Wernet. Introdução à edição brasileira de Mauricio Tragtenberg. $3^{\mathrm{a}}$ ed, São Paulo, Cortez, Campinas, 2001.

VEIGA, Ilma Passos Alencastro. Inovações e Projeto político-pedagógico: uma relação regulatória ou emancipatória? Cadernos Cedes, Campinas, v. 23, p.267-281, dezembro, 2003.

VIEIRA, Fábia Magali Santos.A Formação Inicial de Professores Online. Possibilidades, Contradições e Desafios: 2000 - 2005. 385 f. Tese (Doutorado em Educação). Universidade de Brasília. 2009.

VIEIRA, Fabia Magali Santos, MORAES, Raquel Almeida. As políticas brasileiras para formação de professores a distância, na sociedade capitalista. Revista da Faculdade de Educação da UFG. V.39, n.2. 2014. Disponível em $<$ http://www.revistas.ufg.br/index.php/interacao/issue/view/1522/showToc $>$. Acesso set, 2014.

VIEIRA, Sofia Lerche. FREITAS, Isabel Maria Sabino de. Política educacional no Brasil: introdução histórica. Brasília, Plano Editora, 2003.

UNESCO. Educação um Tesouro a Descobrir. Relatório para Unesco da Comissão Internacional sobre Educação Para o Século XXI. São Paulo, Cortez, 1997.

Declaração Mundial sobre Educação para Todos: satisfação das necessidades

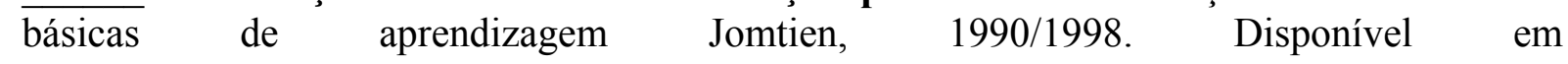
http://unesdoc.unesco.org/images/0008/000862/086291 por.pdf> Acesso fev, 2014.

Declaração de Nova Delhi sobre Educação para Todos. Nova Dehli, 1998. Disponível em <http://unesdoc.UNESCO.org/images/0013/001393/139393por.pdf>, Acesso jan, 2014.

. Educação para Todos: a Declaração de Dakar, CONSED, Ação Educativa, Brasília, DF, 2001. Disponível em $<$ http://unesdoc.UNESCO.org/images/0012/001275/127509porb.pdf> Acesso mar, 2014.

Conferência Mundial sobre Ensino Superior 2009. As Novas Dinâmicas do Ensino Superior e Pesquisas para a Mudança e o Desenvolvimento Social. Paris, 2009. Disponível em $<$ http://portal.mec.gov.br/index.php?option=com_docman\&view=download\&alias $=4512$ conferencia-paris\&Itemid=30192> Acesso mai, 2015. 
El Liderazgo Escolar em America Latina y El Caribe. Um estado del arte com

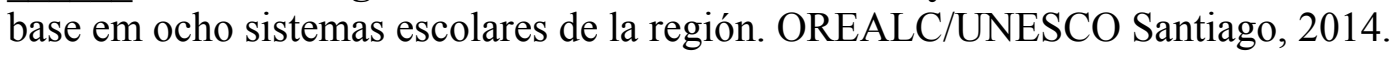

UFT. Projeto Pedagógico do Curso de Especialização em Coordenação Pedagógica PPC. Palmas, TO. UFT, 2010.

. Edital n.01 Propesq/CTE. Seleção para o Curso de Pós-Graduação Lato sensu em Coordenação Pedagógica a distância. Turma 2010. 03 de agosto de 2010.

. Edital n.02Propesq/CTE. Prorrogação da Seleção para o Curso de Pós-Graduação Lato sensu em Coordenação Pedagógica a distância. Turma 2010. 18 de agosto de 2010.

. Edital n.03Propesq/CTE. Prorrogação da Seleção para o Curso de Pós-Graduação Lato sensu em Coordenação Pedagógica a distância. Turma 2010. 19 de setembro de 2010.

Edital n.04Propesq/CTE. Prorrogação da Seleção para o Curso de Pós-Graduação Lato sensu em Coordenação Pedagógica a distância. Turma 2010. 31 de setembro de 2010.

. Edital n.05Propesq/CTE. Prorrogação da Seleção para o Curso de Pós-Graduação Lato sensu em Coordenação Pedagógica a distância. Turma 2010. 28 de outubro de 2010.

Relatório Final do Curso Especialização em Coordenação Pedagógica. Palmas, TO. UFT, 2012.

- Relatório de Avaliação do Curso de Especialização em Coordenação Pedagógica. Palmas, TO. UFT, 2012.

Plano de Trabalho Anual. Palmas, TO. UFT, 2009.

ZINET, Caio. MEC Programa Nacional de Formação e Certificação de Diretores Escolares (PNFCD). Site de Referência em Educação Integral. 2015. Disponível em $<$ http://educacaointegral.org.br/noticias/mec-lanca-programa-de-formacao-para-diretores-deescolas-publicas/> Acesso, mai 2016. 
APÊNDICES 


\section{APÊNDICE I - QUESTIONÁRIO EGRESSOS}

\section{QUESTIONÁRIO: EX-ALUNOS DO CURSO DE ESPECIALIZAÇÃO EM COORDENAÇÃO PEDAGÓGICA (2010-2012) - PNEGEB}

1. Dados gerais e Perfil do cursista

1.1.- Sexo: a. ( ) Masculino b.( ) Feminino

\subsection{Idade:}

a. ( ) Até 30 anos.

b. ( ) De 30 a 60 anos.

c. ( ) Acima de 60 anos.

\subsection{Qual graduação você cursou?}

a. ( ) Pedagogia.

b. ( ) Normal Superior.

c. ( ) Outra Licenciatura:

\subsection{Você realizou o curso superior em qual modalidade?}

a. ( ) Presencial.

b. ( ) Semipresencial.

c. ( ) A distância.

1.5. Possui ou cursa outra pós-graduação além da Especialização em Coordenação Pedagógica do Programa Escola de Gestores?

c.( ) Lato sensu. Especifique:

d.( ) Stricto Sensu (Mestrado). Especifique:

e.( ) Outro:

2.0 Perfil Profissional do Cursista:

2.1 Função exercida atualmente

a. ( ) Coordenador Pedagógico.

b. ( ) Diretor ou Vice-diretor da escola.

c. ( ) Professor.

d. ( ) Outra Função Afim. Especifique:

\subsection{Faixa salarial:}

a.( ) 1 a 4 salários mínimos.

b.( ) 4 a 8 salários mínimos.

c.( ) Acima de 8 salários mínimos.

\subsection{Local de trabalho}

a. ( ) Município em que trabalha:

b. ( ) Superintendência de Ensino:

c. ( ) Nome da escola:

d. ( ) Outro. Especifique:

\subsection{Tempo de exercício na docência:}



a.( ) Menos de 5 anos.
b.( ) De 5 a 20 anos.
c. ( ) Acima de 20 anos.

2.5 Tempo de exercício como Coordenador Pedagógico ou função afim:
a.( ) Menos de 5 anos.
b.( ) De 5 a 20 anos.
c. ( ) Acima de 20 anos.

2.6 Como se tornou coordenador pedagógico?

a) ( ) Seleção Interna na escola.

b) ( ) Indicação/ Nomeação.

c) ( ) Outro:

3 Curso de Especialização em Coordenação Pedagógica - PNEGEB/TO

3.1 Função gestora exercida no período que cursou a pós-graduação em CP

a. ( ) Coordenador Pedagógico.

b. ( ) Suporte Pedagógico.

c. ( ) Outra Função Afim. Especifique:

3.2 Carga horária semanal de trabalho durante o período em que realizou o curso de pósgraduação em Coordenação Pedagógica:

a.( ) Menos de 20h.

b.( ) De 20 a $40 \mathrm{~h}$.

c.( ) Mais de 40h.

\subsection{A Inscrição ao Curso ocorreu por quê?}

a. ( ) Foi informado (a) por uma colega de outra escola.

b. ( ) Foi designado (a) pela escola a realizar.

c. ( ) Outro. Especifique:

3.4 Motivos que o (a) levaram a fazer o curso:

a. ( ) Melhorar a formação.

b. ( ) Aumentar o salário com a titulação do curso.

c. ( ) Alternativas (a) e (b).

d. ( ) Outro. Especifique:

3.5 Residia na mesma cidade polo do curso?

a. ( ) Sim.

b. ( ) Não. Residia a mais de $300 \mathrm{~km}$.

c. ( ) Não. Residia a mais de $200 \mathrm{~km}$.

d. ( ) Não. Residia a mais de $100 \mathrm{~km}$.

3.6 Já cursou outro curso pelo Programa Nacional Escola de Gestores?

a. ( ) Sim. O Curso Piloto em Gestão Escolar.

b. ( ) Sim. O Curso de Especialização em Gestão Escolar.

c. ( ) Não. Só o Curso de Especialização em Coordenação Pedagógica. 
4 Percepções do egresso sobre o curso de especialização em Coordenação Pedagógica do Programa Nacional Escola de Gestores.

Nas questões a seguir, marque apenas UMA alternativa, a que julgar mais importante.

4.1 Sobre o curso de Especialização você considera que:

a. ( ) Colaborou para o fortalecimento da educação inclusiva e da gestão democrática.

b. ( ) Colaborou muito para o fortalecimento da educação inclusiva e da gestão democrática.

c. ( ) Colaborou pouco para o fortalecimento da educação inclusiva e da gestão democrática.

d. ( ) Não colaborou para o fortalecimento da educação inclusiva e da gestão democrática.

\subsection{Você acha que o curso colaborou?}

a) ( ) Mesmo sendo muito teórico, estou conseguindo aplicar o conteúdo na prática de trabalho.

b) ( ) O conteúdo do curso se aplica a minha realidade no Tocantins.

c) ( ) É um curso que me ensinou uma nova ferramenta/ programa de trabalho.

d) ( ) Com a ajuda do curso é possível traçar um planejamento para a escola.

\subsection{Você acha que o curso não colaborou? Escreva resumidamente por quê?}

\subsection{Com que frequência você utiliza os conhecimentos adquiridos no curso?}

a. ( ) Sempre.

b. ( ) Quase sempre.

c. ( ) Eventualmente.

d.( ) Quase nunca.

e.( ) Nunca.

Para as questões abaixo, Responda usando a escala de 1 a 5 de acordo com o grau de concordância com as frases abaixo, sendo: 1 - Concordo Plenamente; 2 - Concordo; 3 Indiferente; 4 - Discordo; 5 - Discordo Plenamente.

\subsection{Percepções sobre o desenvolvimento operacional do curso:}

\begin{tabular}{|l|l|l|l|l|l|}
\hline Percepções & $\mathbf{1}$ & $\mathbf{2}$ & $\mathbf{3}$ & $\mathbf{4}$ & $\mathbf{5}$ \\
\hline $\begin{array}{l}\text { A metodologia do curso por meio da educação a distância foi uma } \\
\text { estratégia acertada. }\end{array}$ & & & & \\
\hline $\begin{array}{l}\text { O AVA (Ambiente Virtual de Aprendizagem/MOODLE) é um } \\
\text { excelente ambiente e não apresentou problemas técnicos durante todo o } \\
\text { curso. }\end{array}$ & & & & \\
\hline $\begin{array}{l}\text { O AVA (Ambiente Virtual de Aprendizagem/MOODLE) é um } \\
\text { excelente ambiente e eu não tive problemas de acesso e de navegação. }\end{array}$ & & & & \\
\hline $\begin{array}{l}\text { Tendo em vista a metodologia utilizada, não tive problemas na } \\
\text { realização, pois durante o curso eu tive acesso à internet e a } \\
\text { computador e tenho facilidade na operação de tecnologias. }\end{array}$ & & & & \\
\hline $\begin{array}{l}\text { A atuação e acompanhamento dos professores foram suficientes para os } \\
\text { debates dos conteúdos, instigando nossa participação. }\end{array}$ & & & & \\
\hline A atuação e acompanhamento dos professores foram suficientes para as & & & & \\
\hline
\end{tabular}




\begin{tabular}{|l|l|l|l|}
\hline orientações das atividades. & & & \\
\hline $\begin{array}{l}\text { A atuação e acompanhamento dos professores foram suficientes para o } \\
\text { desenvolvimento do TCC. }\end{array}$ & & & \\
\hline $\begin{array}{l}\text { Os encontros presenciais foram suficientes e importantes para o sucesso } \\
\text { da minha formação. }\end{array}$ & & & \\
\hline $\begin{array}{l}\text { As atividades e tarefas a distância foram em quantidade suficientes e } \\
\text { com baixo grau de dificuldades de modo que foram realizadas sem } \\
\text { problemas e no tempo solicitado. }\end{array}$ & & & \\
\hline $\begin{array}{l}\text { Os Fóruns de debates, dúvidas e questionamentos foram utilizados por } \\
\text { mim com frequência e, em quase todos, tive bom feedback dos } \\
\text { professores. }\end{array}$ & & & \\
\hline $\begin{array}{l}\text { A metodologia do curso permite e proporciona que o aluno desenvolva } \\
\text { seu potencial crítico e reflexivo por meio da participação nos debates e } \\
\text { na produção das atividades individuais e em grupo. }\end{array}$ & & & \\
\hline $\begin{array}{l}\text { Os Instrumentos de avaliação (atividades on-line, produção individual, } \\
\text { memoriais reflexivos, TCC) foram importantes para a reflexão sobre o } \\
\text { conteúdo estudado e a avaliação se desenvolveu de forma processual e } \\
\text { dialógica. }\end{array}$ & & & \\
\hline $\begin{array}{l}\text { O Material didático utilizado, bem como os textos, os vídeos, as } \\
\text { referências bibliográficas sugeridas foram suficientes e atualizados. }\end{array}$ & & & \\
\hline $\begin{array}{l}\text { Não tive problemas para o cumprimento do cronograma de trabalho das } \\
\text { salas ambientes e do curso em geral. }\end{array}$ & & & \\
\hline $\begin{array}{l}\text { Durante o curso, mantive minha função de coordenador pedagógico na } \\
\text { escola. }\end{array}$ & & & \\
\hline
\end{tabular}

\subsection{Em relação aos objetivos e metas do curso:}

\begin{tabular}{|c|c|c|c|c|c|}
\hline Percepções & 1 & 2 & 3 & 4 & 5 \\
\hline $\begin{array}{l}\text { O curso ajudou na ampliação de minhas capacidades de análise e } \\
\text { resolução de problemas, elaboração e desenvolvimento de projetos e } \\
\text { atividades no âmbito da organização do trabalho pedagógico e do } \\
\text { processo de ensino-aprendizagem. }\end{array}$ & & & & & \\
\hline $\begin{array}{l}\text { Possibilitou-me a vivência de processos de produção de conhecimentos } \\
\text { para melhor compreensão da escola em suas múltiplas determinações. }\end{array}$ & & & & & \\
\hline $\begin{array}{l}\text { Auxiliou-me na reflexão e na prática de ações e orientações junto ao } \\
\text { trabalho do professor para a realização do processo de ensino- } \\
\text { aprendizagem. }\end{array}$ & & & & & \\
\hline $\begin{array}{l}\text { Possibilitou o aprofundamento dos debates sobre a construção coletiva } \\
\text { do projeto pedagógico, bem como da articulação, integração e } \\
\text { organização das ações pedagógicas. }\end{array}$ & & & & & \\
\hline $\begin{array}{l}\text { Aprofundou a compreensão da educação escolar como direito } \\
\text { fundamental do cidadão e como instrumento de emancipação humana } \\
\text { no contexto de uma sociedade com justiça social. }\end{array}$ & & & & & \\
\hline $\begin{array}{l}\text { Compreensão sobre a realidade escolar e a gestão dos processos } \\
\text { educativos nas dimensões social, política, cultural, econômica e } \\
\text { pedagógica. }\end{array}$ & & & & & \\
\hline $\begin{array}{l}\text { Compreensão sobre os meios de comunicação como espaços de } \\
\text { produção, socialização e disseminação de informações, saberes, } \\
\text { conhecimentos e culturas e, portanto, como possibilidades de }\end{array}$ & & & & & \\
\hline
\end{tabular}




\begin{tabular}{|l|l|l|l|l|}
\hline descentralização de poderes e de promoção da autonomia. & & & & \\
\hline $\begin{array}{l}\text { Possibilitou o domínio da utilização de ferramentas tecnológicas no } \\
\text { campo da organização dos processos de trabalho nos sistemas e }\end{array}$ & & & & \\
unidades de ensino.
\end{tabular}

\subsection{Mudanças ocorridas na prática profissional resultantes do curso:}

\begin{tabular}{|c|c|c|c|c|c|}
\hline \multirow{2}{*}{$\begin{array}{l}\text { Percepções } \\
\text { Os conhecimentos do curso me ajudaram na organização do trabalho } \\
\text { pedagógico e na gestão dos acontecimentos do dia a dia da escola e da } \\
\text { sala de aula. }\end{array}$} & 1 & 2 & 3 & 4 & 5 \\
\hline & & & & & \\
\hline \multicolumn{6}{|l|}{$\begin{array}{l}\text { O curso contribuiu para despertar mais autonomia pedagógica da } \\
\text { escola. }\end{array}$} \\
\hline \multirow{2}{*}{\multicolumn{6}{|c|}{$\begin{array}{l}\text { O curso influenciou na melhoria da qualidade da escola. } \\
\text { Ampliou minha visão a respeito do trabalho do coordenador } \\
\text { pedagógico e da minha identidade profissional. }\end{array}$}} \\
\hline & & & & & \\
\hline \multicolumn{6}{|l|}{$\begin{array}{l}\text { O curso contribuiu para melhorar meu relacionamento com os } \\
\text { professores e funcionários. }\end{array}$} \\
\hline \multicolumn{6}{|l|}{ O curso contribuiu para melhorar meu relacionamento com os alunos. } \\
\hline \multicolumn{6}{|l|}{$\begin{array}{l}\text { O curso permitiu propor soluções para problemas práticos e } \\
\text { pedagógicos. }\end{array}$} \\
\hline \multicolumn{6}{|l|}{ O curso supriu deficiências da minha formação inicial (graduação). } \\
\hline \multicolumn{6}{|l|}{$\begin{array}{l}\text { O curso respondeu as minhas necessidades e anseios de formação em } \\
\text { coordenação pedagógica. }\end{array}$} \\
\hline $\begin{array}{l}\text { O Projeto-intervenção e o Trabalho de Conclusão do Curso se } \\
\text { transformaram em ações efetivas na escola. }\end{array}$ & & & & & \\
\hline
\end{tabular}

\subsection{Percepções sobre as Parcerias estabelecidas para o funcionamento do curso:}

\begin{tabular}{|l|l|l|l|l|}
\hline $\begin{array}{l}\text { A Universidade Federal do Tocantins (UFT) viabilizou as condições } \\
\text { necessárias para o desenvolvimento do curso de pós-graduação lato } \\
\text { sensu. }\end{array}$ & & & & \\
\hline $\begin{array}{l}\text { A Secretaria Municipal ou Estadual de Educação viabilizou a minha } \\
\text { participação no curso flexibilizando meu horário de trabalho para a } \\
\text { realizaça das atividades. }\end{array}$ & & & & \\
\hline $\begin{array}{l}\text { A Secretaria Municipal ou Estadual de Educação viabilizou a minha } \\
\text { participação no curso me auxiliando financeiramente para participar } \\
\text { dos encontros presenciais. }\end{array}$ & & & & \\
\hline $\begin{array}{l}\text { A Secretaria Municipal ou Estadual de Educação viabilizou a minha } \\
\text { participação no curso respeitando minha atuação como coordenador } \\
\text { pedagógico, bem como, apoiando as ações do meu projeto de } \\
\text { intervenção. }\end{array}$ & & & & \\
\hline $\begin{array}{l}\text { O Ministério de Educação (MEC) formulou uma política de formação } \\
\text { de professores/gestores adequada à realidade do estado do Tocantins. }\end{array}$ & & & \\
\hline
\end{tabular}




\section{APÊNDICE II - QUESTIONÁRIO PROFESSORES DO CURSO}

\section{COLABORADORES NO CURSO DE ESPECIALIZAÇÃO EM COORDENAÇÃO PEDAGÓGICA (2010-2012) - PNEGEB-TO}

\subsection{Dados Gerais do Colaborador}

\subsection{Qual sua graduação?}
a. ( ) Pedagogia.
b. ( ) Normal Superior.
c. ( ) Outra.

1.2 De que forma você realizou o curso superior?
a. ( ) Presencial.
b. ( ) Semipresencial.
c. ( ) A distância.

1.3 Possuía alguma pós-graduação no período de participação no curso?
a. ( ) Especialização.
b. ( ) Mestrado.
c. ( ) Doutorado.
d. ( ) Não possuía.

1.4 Possuía alguma pós-graduação específica na área de políticas educacionais ou gestão escolar no período de participação do curso?
a. ( ) Sim.
b. ( ) Não.

1.5 Com relação à sua função profissional na época do curso, você era professor:
a. ( ) Da Universidade Federal do Tocantins - UFT.
b. ( ) De escolas do Estado do Tocantins.
c. ( ) De escolas dos Municípios participantes do curso.
d. ( ) Da UNITINS.
e. ( ) Outro:

1.6 Não era professor (a) e sim funcionário (a) de apoio administrativo e/ou pedagógico:
a. ( ) Da Universidade Federal do Tocantins - UFT.
b. ( ) Do Estado do Tocantins.
c. ( ) De órgãos dos Municípios participantes do curso.
d. ( ) Da UNITINS.
e. ( ) Outro:

1.7 Sua experiência com cursos de educação a distância ao atuar como colaborador (a) foi:

a.( ) Apenas como aluno(a) em cursos dessa modalidade.

b.( ) De professor (pesquisador, conteudista, orientador).

c.( ) De tutor.

e.( ) Outro: 


\subsection{Atuação como colaborador (a) no curso de especialização em CP}

\subsection{Como se tornou professor/colaborador do curso?}
a. ( ) Por meio de um convite da coordenação geral do curso.
b. ( ) Pela indicação da secretaria municipal.
c. ( ) Pela indicação da secretaria estadual.
d. ( ) Outro:

\subsection{Exercia a função de: \\ a.( ) Professor Regente. \\ b.( ) Professor de Turma. \\ c.( ) Assistente de Turma. \\ d. ( ) Assistente de Polo. \\ e.( ) Outra:}

2.3 Considerando sua carga horária de trabalho diária e somando as horas dedicadas ao curso, qual o total de horas trabalhadas por semana, aproximadamente?
a. ( ) De 20 a 30h/s.
b. ( ) De 30 a $40 \mathrm{~h} / \mathrm{s}$.
c. ( ) De 40 a $50 \mathrm{~h} / \mathrm{s}$.
d. ( ) Mais de 50h/s.
e.( ) Outro:

2.4 Com relação a essa carga horária de trabalho semanal, você considera que:

a.( ) Foi tranquila e era possível realizar um bom trabalho em ambas as funções.

b.( ) Não foi tranquila e você teve que se desdobrar muito para realizar bem ambas as funções.

c. ( ) Acredita que a carga horária de dedicação ao curso deveria ser menor.

d. ( ) Acredita que a carga horária é flexível tendo em vista a modalidade a distância.

e.( ) Alternativas (a) e (d).

f. ( ) Alternativas (b) e (c).

3. Sua percepção sobre a formação dos egressos no curso de especialização.

3.1 Com relação à dedicação dos cursistas, você considera que:

a. ( ) Os alunos se dedicaram a $10 \mathrm{~h}$ semanais para realização do curso.

b. ( ) Os alunos não se dedicaram a $10 \mathrm{~h}$ semanais para realização do curso, pois dentre outros motivos, alegavam não ter tempo.

c. ( ) Mesmo diante de alegações dos alunos de que não tinham tempo para realizar o curso, você percebeu que a maioria se esforçou para realizá-lo.

d. ( ) Outro:

3.2 Sobre o curso de Especialização você considera que:

a. ( ) Colaborou para o fortalecimento da educação inclusiva e da gestão democrática.

b. ( ) Colaborou muito para o fortalecimento da educação inclusiva e da gestão democrática.

c. ( ) Colaborou pouco para o fortalecimento da educação inclusiva e da gestão democrática.

d. ( ) Não colaborou para o fortalecimento da educação inclusiva e da gestão democrática.

e. ( ) Outro:

3.3 Se você acha que o curso colaborou, marque uma alternativa:

a. ( ) Mesmo sendo muito teórico, o egresso pode aplicar o conteúdo na prática de trabalho.

b. ( ) O conteúdo do curso se aplica à realidade do egresso no Tocantins. 
c. ( ) É um curso que ensinou uma nova ferramenta/ programa de trabalho.

d. ( ) Com a ajuda do curso é possível ao egresso traçar um planejamento para a escola.

e. ( ) Todas alternativas.

f. ( ) Outro:

3.4 Se você acha que o curso não colaborou, marque uma alternativa:

a. ( ) Curso muito teórico e o egresso não pode aplicar o conteúdo na prática de trabalho.

b. ( ) O conteúdo do curso não se aplica à realidade do egresso no Tocantins.

c. ( ) É um curso que não ensinou uma nova ferramenta/ programa de trabalho.

d. ( ) O curso não auxiliou o egresso a traçar um planejamento para a escola.

e. ( ) Todas alternativas

f. ( ) Outro:

Para as questões abaixo, responda usando a escala de 1 a 5 de acordo com o grau de concordância com as frases abaixo:1 - Concordo Plenamente; 2 - Concordo; 3 Indiferente; 4 - Discordo; 5 - Discordo Plenamente.

\section{Percepções sobre o desenvolvimento operacional do curso:}

\begin{tabular}{|l|l|l|l|l|}
\hline Percepções & $\mathbf{1}$ & $\mathbf{2}$ & $\mathbf{4}$ & $\mathbf{5}$ \\
\hline $\begin{array}{l}\text { O AVA (Ambiente Virtual de Aprendizagem/MOODLE) é um } \\
\text { excelente ambiente e não apresentou problemas técnicos durante todo o } \\
\text { curso. }\end{array}$ & & & & \\
\hline Os cursistas não tiveram problemas de acesso e de navegação ao AVA. & & & & \\
\hline $\begin{array}{l}\text { A metodologia da educação a distância (EAD) foi uma estratégia } \\
\text { acertada. }\end{array}$ & & & \\
\hline $\begin{array}{l}\text { A metodologia EAD permitiu e proporcionou ao cursista desenvolver o } \\
\text { potencial crítico e reflexivo por meio da participação nos debates e na } \\
\text { produção das atividades individuais e em grupo. }\end{array}$ & & & & \\
\hline $\begin{array}{l}\text { Considerando essa metodologia, os cursistas não tiveram problemas, } \\
\text { pois durante o curso tiveram acesso à internet e a computador e } \\
\text { apresentaram facilidade com o manuseio de tecnologias. }\end{array}$ & & & & \\
\hline $\begin{array}{l}\text { A atuação e acompanhamento dos professores foram suficientes para os } \\
\text { debates dos conteúdos, instigando participação. }\end{array}$ & & & \\
\hline $\begin{array}{l}\text { A atuação e acompanhamento dos professores foram suficientes para as } \\
\text { orientações das atividades. }\end{array}$ & & & \\
\hline $\begin{array}{l}\text { A atuação e acompanhamento dos professores foram suficientes para o } \\
\text { desenvolvimento do TCC. }\end{array}$ & & & & \\
\hline $\begin{array}{l}\text { Os encontros presenciais foram suficientes e importantes para o sucesso } \\
\text { da formação dos cursistas. }\end{array}$ & & & & \\
\hline $\begin{array}{l}\text { As atividades e tarefas a distância foram em quantidade suficientes e } \\
\text { com baixo grau de dificuldades de modo que foram realizadas sem } \\
\text { problemas e no tempo solicitado. }\end{array}$ & & & & \\
\hline $\begin{array}{l}\text { Os Fóruns de debates, dúvidas e questionamentos foram utilizados } \\
\text { pelos cursistas com frequência e, em quase todos, os professores deram } \\
\text { um bom feedback. }\end{array}$ & & & & \\
\hline $\begin{array}{l}\text { Os Instrumentos de avaliação (atividades on-line, produção individual, } \\
\text { memoriais reflexivos, TCC...) foram importantes para a reflexão sobre } \\
\text { o conteúdo estudado e a avaliação se desenvolveu de forma processual } \\
\text { e dialógica. }\end{array}$ & & & & \\
\hline
\end{tabular}




\begin{tabular}{|l|l|l|l|l|}
\hline $\begin{array}{l}\text { O Material didático utilizado, bem como os textos, os vídeos, as } \\
\text { referências bibliográficas sugeridas foram suficientes e atualizadas. }\end{array}$ & & & \\
\hline $\begin{array}{l}\text { Os cursistas não tiveram problemas para o cumprimento do cronograma } \\
\text { de trabalho das salas ambientes e do curso em geral. }\end{array}$ & & & \\
\hline $\begin{array}{l}\text { Os cursistas se mantiveram na função de coordenação pedagógica } \\
\text { durante o curso e, com isso, conseguiram implantar o projeto de } \\
\text { intervenção sem problemas nas escolas. }\end{array}$ & & & & \\
\hline
\end{tabular}

\section{Em relação aos objetivos e metas do curso, você considera que auxiliou os cursistas:}

\begin{tabular}{|l|l|l|l|l|}
\hline Percepções & $\mathbf{2}$ & $\mathbf{3}$ & $\mathbf{4}$ & $\mathbf{5}$ \\
\hline $\begin{array}{l}\text { Na ampliação das capacidades de análise e resolução de problemas, } \\
\text { elaboração e desenvolvimento de projetos e atividades no âmbito da } \\
\text { organização do trabalho pedagógico e do processo de ensino- } \\
\text { aprendizagem. }\end{array}$ & & & & \\
\hline $\begin{array}{l}\text { Na construção de conhecimentos para que melhorassem a compreensão } \\
\text { da escola como direito fundamental do cidadão e instrumento de } \\
\text { emancipação humana. }\end{array}$ & & & & \\
\hline $\begin{array}{l}\text { Na reflexão e na prática de ações e orientações junto ao trabalho do } \\
\text { professor. }\end{array}$ & & & \\
\hline $\begin{array}{l}\text { Na participação dos debates sobre a construção coletiva do projeto } \\
\text { pedagógico, bem como na articulação, integração e organização das } \\
\text { ações pedagógicas. }\end{array}$ & & & & \\
\hline $\begin{array}{l}\text { Na compreensão sobre os meios de comunicação como espaços de } \\
\text { produção, socialização e disseminação de informações, saberes, } \\
\text { conhecimentos e culturas. }\end{array}$ & & & & \\
\hline $\begin{array}{l}\text { Na utilização dos meios de comunicação como instrumentos de } \\
\text { descentralização de poderes e de promoção de autonomia. }\end{array}$ & & & \\
\hline $\begin{array}{l}\text { No domínio de ferramentas tecnológicas no campo da organização dos } \\
\text { processos de trabalho pedagógico com vistas ao desenvolvimento de } \\
\text { uma escola mais democrática. }\end{array}$ & & & & \\
\hline
\end{tabular}

\section{Percepções sobre as Parcerias estabelecidas para o funcionamento do curso:}

\begin{tabular}{|l|l|l|l|l|}
\hline $\begin{array}{l}\text { A Universidade Federal do Tocantins (UFT) viabilizou as condições } \\
\text { necessárias para o desenvolvimento do curso de pós-graduação lato } \\
\text { sensu. }\end{array}$ & & & & \\
\hline $\begin{array}{l}\text { A Secretaria Municipal ou Estadual de Educação viabilizou a } \\
\text { participação dos cursistas flexibilizando o horário de trabalho para a } \\
\text { realização das atividades. }\end{array}$ & & & & \\
\hline $\begin{array}{l}\text { A Secretaria Municipal ou Estadual de Educação viabilizou a } \\
\text { participação dos cursistas auxiliando-os financeiramente para participar } \\
\text { dos encontros presenciais. }\end{array}$ & & & & \\
\hline $\begin{array}{l}\text { A Secretaria Municipal ou Estadual de Educação viabilizou a } \\
\text { participação dos cursistas respeitando a atuação do coordenador } \\
\text { pedagógico, bem como, apoiando as ações do projeto de intervenção. }\end{array}$ & & & & \\
\hline $\begin{array}{l}\text { O Ministério de Educação (MEC) formulou uma política de formação } \\
\text { de professores/gestores adequada à realidade do estado do Tocantins. }\end{array}$ & & & & \\
\hline
\end{tabular}




\section{APÊNDICE III - QUESTIONÁRIO GESTOR}

\section{Sobre o Processo de implantação do PNEGEB em âmbito Nacional}

\section{Efeitos do curso de Especialização em Coordenação Pedagógica do PNEGEB na formação dos cursistas}

1) Em sua opinião, quais os efeitos da política PNEGEB para a formação de coordenadores pedagógicos?

2) Como você analisa a parceria entre a União, Estados e Municípios para o desenvolvimento da política em âmbito nacional e regional?

3) Para as questões abaixo, responda usando a escala de 1 a 5 de acordo com o grau de concordância com as frases:1 - Concordo Plenamente; 2 - Concordo; 3 - Indiferente; 4 Discordo; 5 - Discordo Plenamente.

\subsection{Percepções sobre o desenvolvimento operacional do curso:}

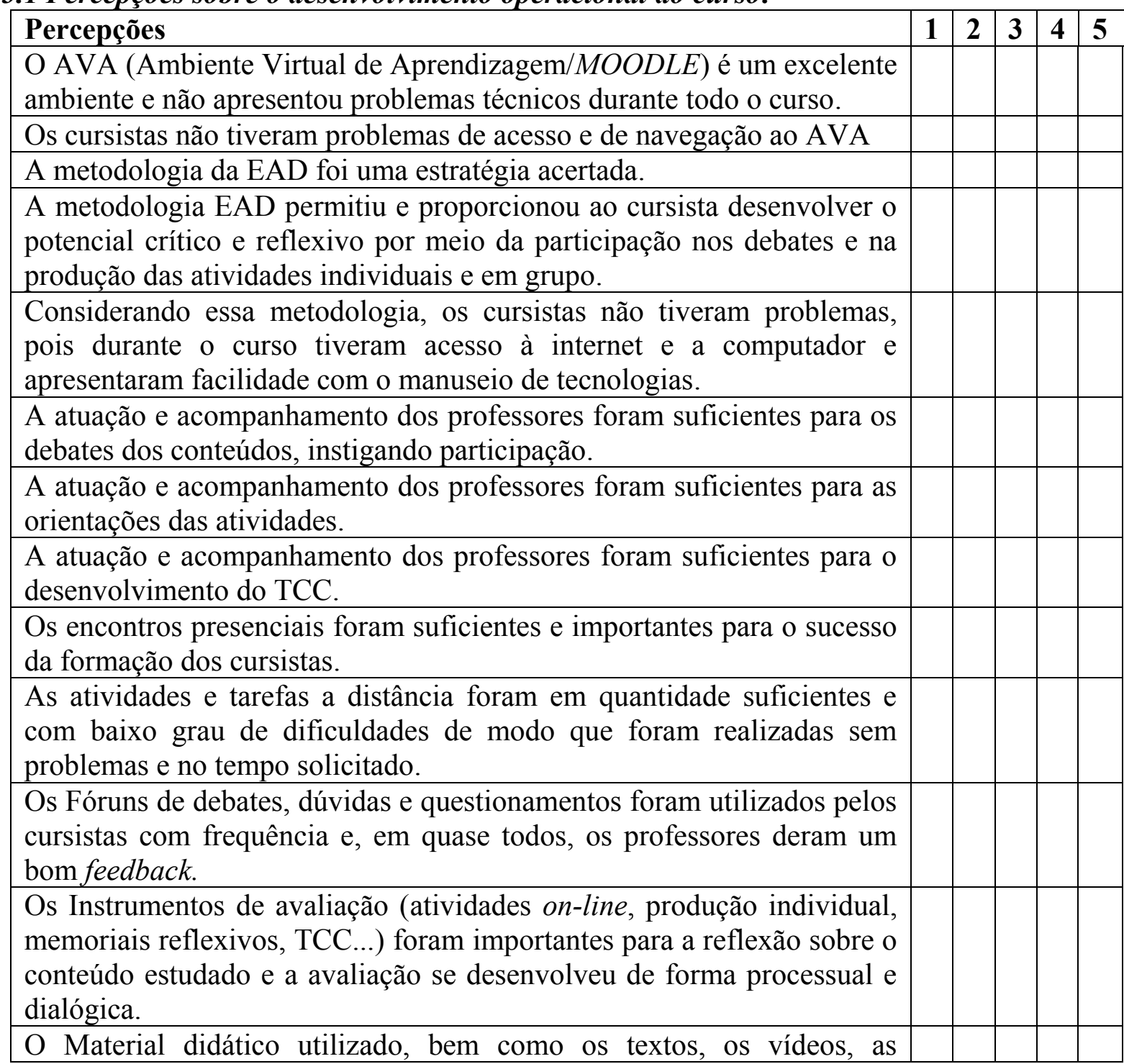


referências bibliográficas sugeridas foram suficientes e atualizadas.

Os cursistas não tiveram problemas para o cumprimento do cronograma de trabalho das salas ambientes e do curso em geral.

Os cursistas se mantiveram na função de coordenação pedagógica durante o curso e com isso, conseguiram implantar o projeto de intervenção sem problemas nas escolas.

\subsection{Em relação aos objetivos e metas do curso, você considera que auxiliou os cursistas:}

\begin{tabular}{|l|l|l|l|l|}
\hline Percepções & $\mathbf{2}$ & $\mathbf{3}$ & $\mathbf{4}$ & $\mathbf{5}$ \\
\hline $\begin{array}{l}\text { Na ampliação das capacidades de análise e resolução de problemas, } \\
\text { elaboração e desenvolvimento de projetos e atividades no âmbito da } \\
\text { organização do trabalho pedagógico e do processo de ensino- } \\
\text { aprendizagem. }\end{array}$ & & & & \\
\hline $\begin{array}{l}\text { Na construção de conhecimentos para que melhorassem a compreensão } \\
\text { da escola como direito fundamental do cidadão e instrumento de } \\
\text { emancipação humana. }\end{array}$ & & & & \\
\hline $\begin{array}{l}\text { Na reflexão e na prática de ações e orientações junto ao trabalho do } \\
\text { professor. }\end{array}$ & & & \\
\hline $\begin{array}{l}\text { Na participação dos debates sobre a construção coletiva do projeto } \\
\text { pedagógico, bem como na articulação, integração e organização das } \\
\text { ações pedagógicas. }\end{array}$ & & & & \\
\hline $\begin{array}{l}\text { Na compreensão sobre os meios de comunicação como espaços de } \\
\text { produção, socialização e disseminação de informações, saberes, } \\
\text { conhecimentos e culturas. }\end{array}$ & & & & \\
\hline $\begin{array}{l}\text { Na utilização dos meios de comunicação como instrumentos de } \\
\text { descentralização de poderes e de promoção de autonomia. }\end{array}$ & & & \\
\hline $\begin{array}{l}\text { No domínio de ferramentas tecnológicas no campo da organização dos } \\
\text { processos de trabalho pedagógico com vistas ao desenvolvimento de } \\
\text { uma escola mais democrática. }\end{array}$ & & & & \\
\hline
\end{tabular}

\subsection{Percepções sobre as Parcerias estabelecidas para o funcionamento do curso:}

\begin{tabular}{|l|l|l|l|l|}
\hline $\begin{array}{l}\text { A Universidade Federal do Tocantins (UFT) viabilizou as condições } \\
\text { necessárias para o desenvolvimento do curso de pós-graduação lato } \\
\text { sensu. }\end{array}$ & & & & \\
\hline $\begin{array}{l}\text { A Secretaria Municipal ou Estadual de Educação viabilizou a } \\
\text { participação dos cursistas flexibilizando o horário de trabalho para a } \\
\text { realização das atividades. }\end{array}$ & & & & \\
\hline $\begin{array}{l}\text { A Secretaria Municipal ou Estadual de Educação viabilizou a } \\
\text { participação dos cursistas auxiliando-os financeiramente para participar } \\
\text { dos encontros presenciais. }\end{array}$ & & & & \\
\hline $\begin{array}{l}\text { A Secretaria Municipal ou Estadual de Educação viabilizou a a } \\
\text { participação dos cursistas respeitando a atuação do coordenador } \\
\text { pedagógico, bem como, apoiando as ações do projeto de intervenção. }\end{array}$ & & & & \\
\hline $\begin{array}{l}\text { O Ministério de Educação (MEC) formulou uma política de formação } \\
\text { de professores/gestores adequada à realidade do estado do Tocantins. }\end{array}$ & & & & \\
\hline
\end{tabular}




\section{APÊNDICE IV - TERMO DE CONSENTIMENTO LIVRE E ESCLARECIDO}

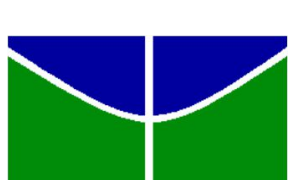

UNIVERSIDADE DE BRASÍLIA - UnB

FACULDADE DE EDUCAÇÃO - FE

PROGRAMA DE PÓS-GRADUAÇÃO EM EDUCAÇÃO

LINHA DE PESQUISA: POLÍTICAS E GESTÃO DA EDUCAÇÃO - POGE

Termo de consentimento livre e esclarecido

Responsável pelo projeto: RAQUEL APARECIDA SOUZA - Matrícula 130051993

Pesquisa de Doutorado em Educação, sob a orientação da Professora Doutora Raquel de Almeida Moraes.

$\mathrm{Eu}$,

fui devidamente informado (a) e esclarecido (a) sobre a pesquisa "FORMAÇÃo DE Professores/Coordenadores Pedagógicos a Partir do Programa Nacional ESCOLA DE GESTORES: A EXPERIÊNCIA NO TOCANTINS" e os procedimentos nela envolvidos, bem como, foi me assegurado (a) a preservação total de minha identidade. Assim, autorizo a divulgação das minhas informações para fins científicos, sem restrições de citações dos dados obtidos, por tempo indeterminado, em meios impressos, digitais e outros.

Tocantins, de de 